\title{
Piotr Bielski
}

\section{Rolnictwo ekologiczne jako zawód i powołanie.} Studium tożsamości, organizacji i potencjału rozwojowego polskich rolników ekologicznych.

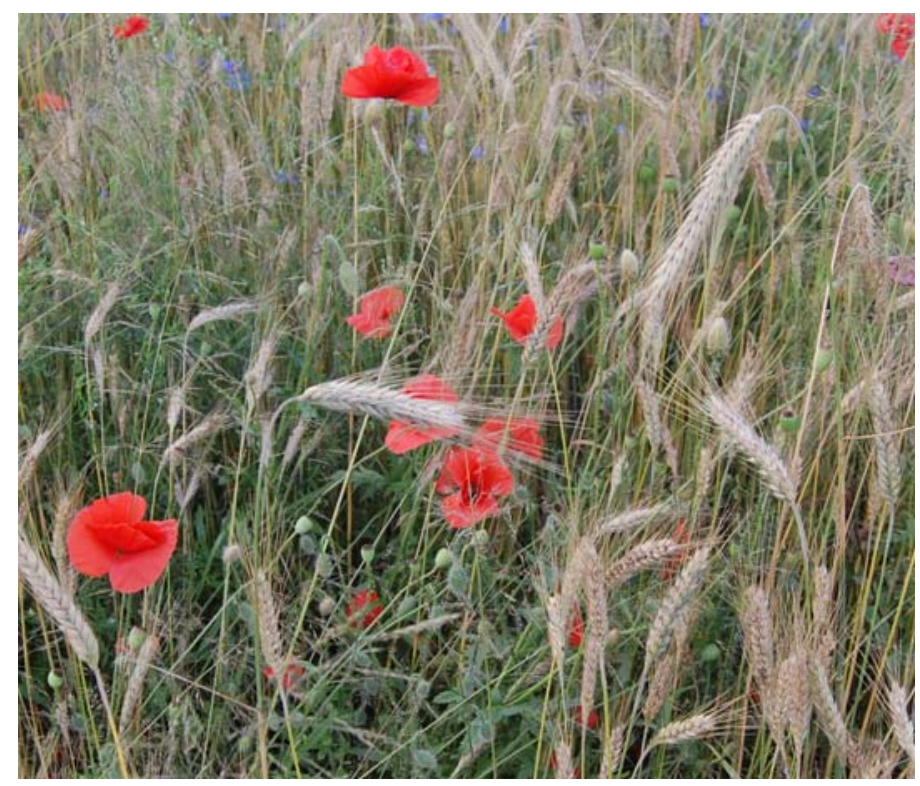

SERIA

...BECOMING...

2009 


\section{Spis treści}

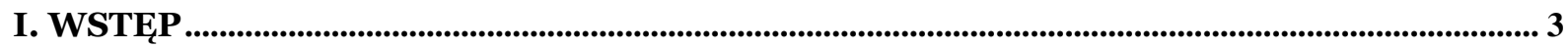

II. METODOLOGIA BADAŃ WŁASNYCH .................................................................................. 10

1. TEORIA UGRUNTOWANA JAKO OPCJA PARADYGMATYCZNO - METODOLOGICZNA ...................................... 10

2 CHARAKTERYSTYKA PODSTAWOWYCH ZAŁOŻEŃ I PROCEDUR BADAWCZYCH TEORII UGRUNTOWANEJ ........ 16

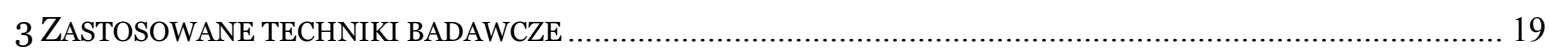

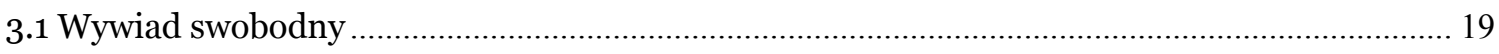

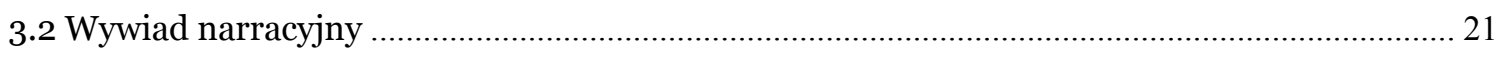

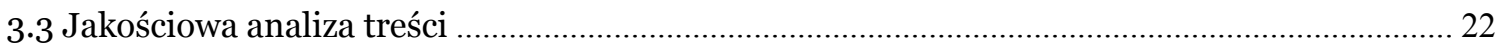

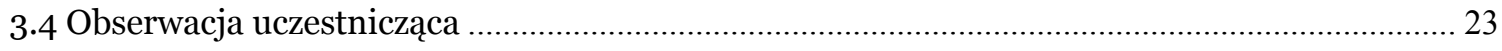

III. KONTEKST HISTORYCZNY I IDEOLOGICZNY ROZWOJU ROLNICTWA

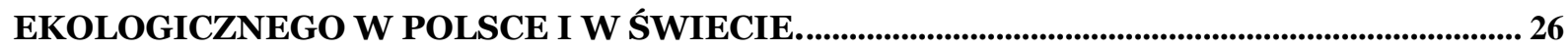

1. PRZEDSTAWIENIE GŁÓWNYCH SZKÓ£ I TECHNIK ROLNICTWA EKOLOGICZNEGO ......................................... 26

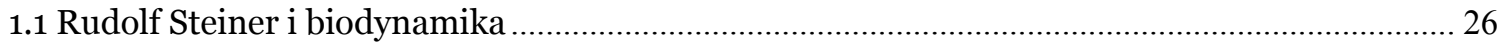

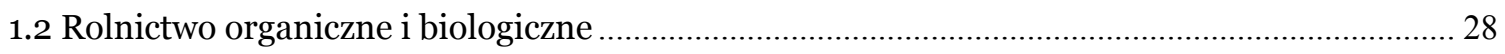

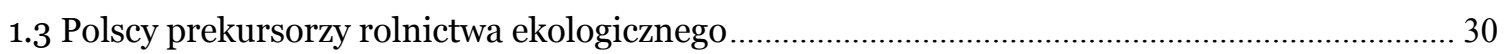

2. IFOAM I KONSOLIDACJA MIĘDZYNARODOWEGO RUCHU ROLNICTWA EKOLOGICZNEGO........................... 32

3. ROZWÓJ ROLNICTWA EKOLOGICZNEGO W POLSCE - WSTĄPIENIE DO UNII EUROPEJSKIEJ JAKO PUNKT

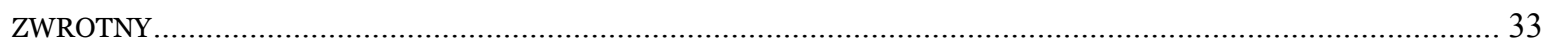

IV. ROLNICTWO EKOLOGICZNE JAKO ZAWÓD I POWOŁANIE................................................ 38

1. ŚWIAT SPOŁECZNY ROLNICTWA EKOLOGICZNEGO - AKTORZY, ARENY SPORÓW.............................................. 38

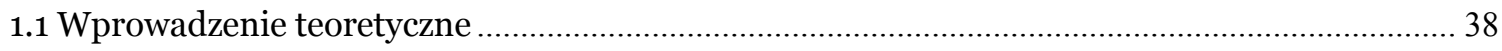

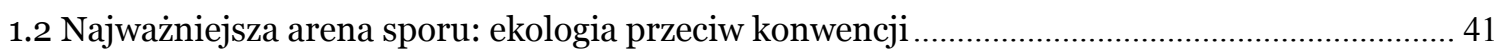

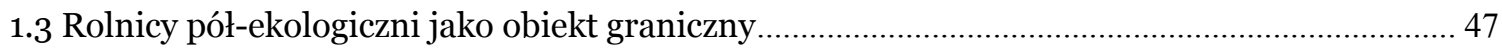

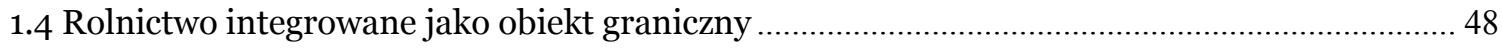

1.5 Wytyczanie granic - agencje certyfikacyjne jako szczególni aktorzy ………............................... 51

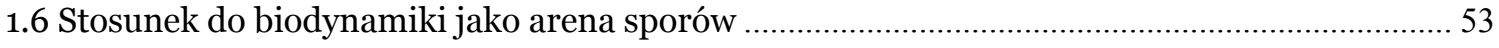

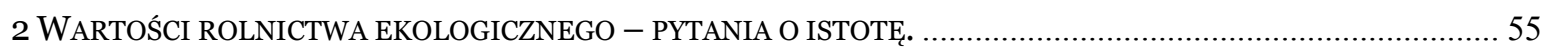

2.1 Wizja aksjologiczna rolnictwa ekologicznego jako nowego ruchu społecznego .......................... 55

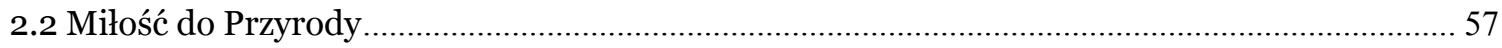

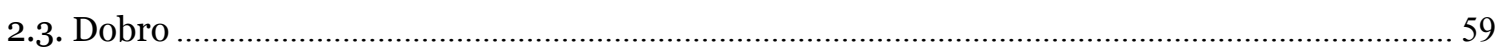

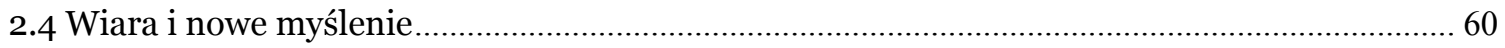

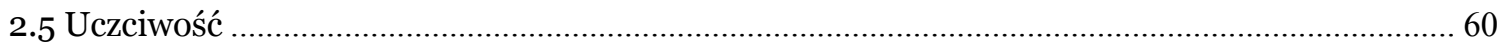

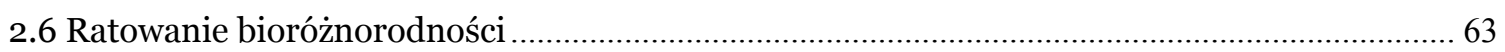

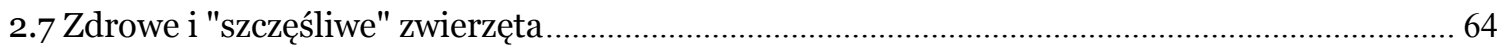

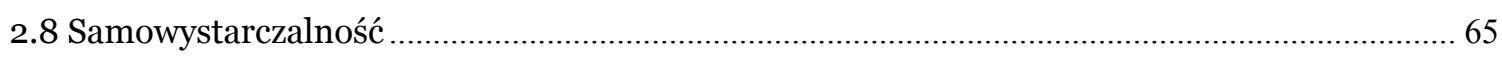

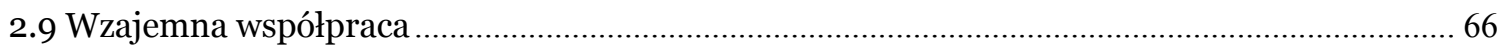




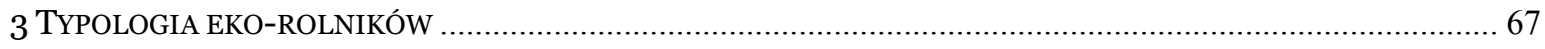

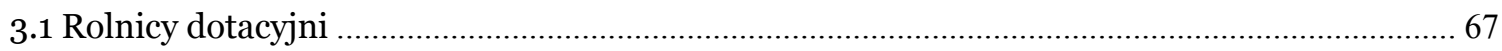

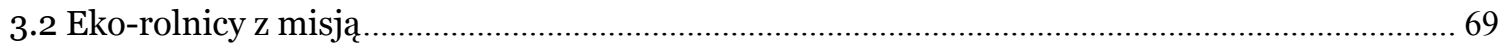

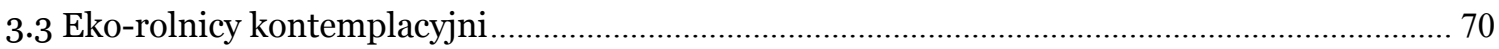

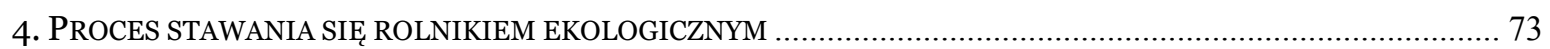

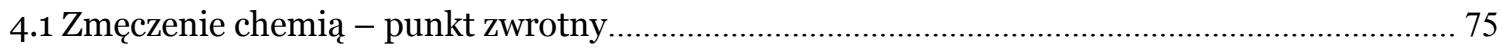

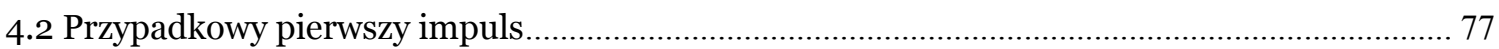

4.3 "Osobista przygoda" (poznanie znaczących innych) ............................................................. 77

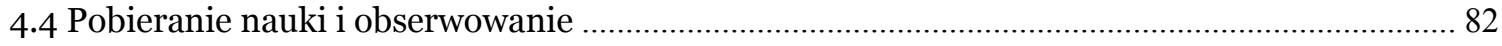

4.5 Bariery: drwiny ze strony pierwotnej grupy odniesienia i niskie plony ................................... 83

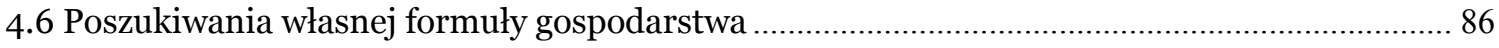

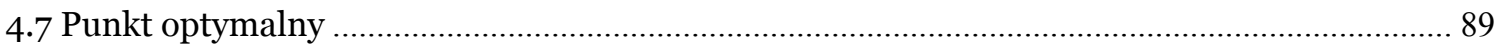

5 GŁÓWNI AKTORZY SPOŁECZNEGO ŚWIATA. CHARAKTERYSTYKA ORGANIZACJI ROLNIKÓW EKOLOGICZNYCH.

5.1 Ekoland jako największa i najstarsza ogólnopolska organizacja ......................................... 92

5.2 Eko-Centrum Zelów jako przykład aktywnej organizacji lokalnej...........................................95

5.3 Klastry - ku rolnictwu ekspercko-ekologicznemu? Fenomen Doliny Ekologicznej Żywności . 95

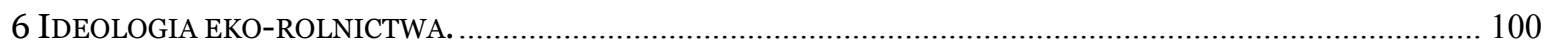

6.1 Mieczysław Górny jako ojciec polskiego rolnictwa ekologicznego ....................................... 101

6.2 Zbigniew Przybylak i kwartalnik Eko Arka - między praktycznością a mistycyzmem ........... 103

6.3 Rolnictwo ekologiczne - pomiędzy konserwatyzmem a high tech ........................................ 111

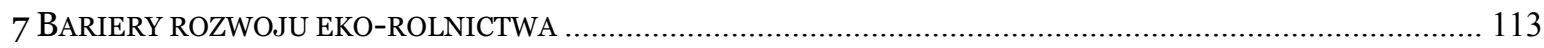

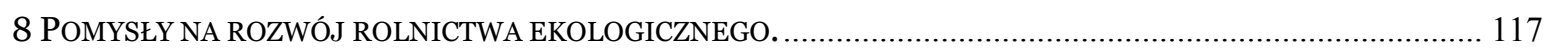

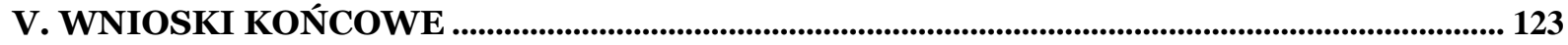

VI. POST SCRIPTUM. MIĘDZY EKO-OGRÓDKIEM PRZY BIAEYM DOMU A GROŹBĄ LIKWIDACJI, CZYLI CO ZMIENIŁO SIĘ W EKO-ROLNICTWIE W CIĄGU DWÓCH LAT

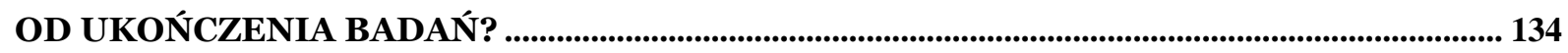

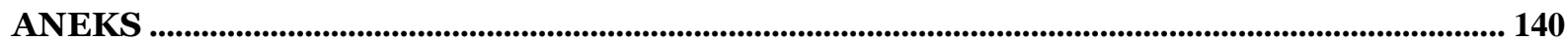

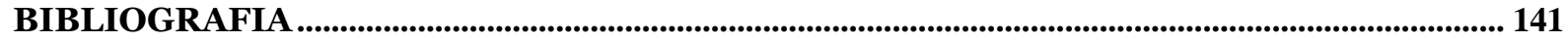




\section{Wstęp}

Moja fascynacja rolnictwem ekologicznym została uwarunkowana sięgającymi wczesnej młodości doświadczeniami $\mathrm{w}$ ruchu ekologicznym, jak również zainteresowaniem życiem oraz działalnością społeczną na wsi.

Od kilku lat mam kontakt ze środowiskiem rolników ekologicznych, co związane jest m.in. z faktem, iż od 9 lat jestem wegetarianinem i zaopatruję się w żywność $\mathrm{w}$ lódzkich sklepach z żywnością wegetariańską, gdzie sukcesywnie poznawałem kolejnych dostawców - rolników ekologicznych z łódzkiego. Z jednym $\mathrm{z}$ nich moja rodzina nawiązała stałą współpracę $\mathrm{w}$ ramach sieci sprzedaży bezpośredniej. Ów rolnik poświęca dwa dni w tygodniu na dostarczanie bezpośrednio do zainteresowanych klientów żywności wyprodukowanej przez siebie i swoich kolegów, sprzedając ją po niższej, pozbawionej sklepowej marży, cenie. Rozmowy z nim pozwoliły mi na stopniowe wkraczanie $\mathrm{w}$ świat społeczny rolników ekologicznych. Dostawca niejednokrotnie opowiadał o barierach i problemach z jakimi spotyka się na co dzień, m.in. z brakiem zrozumienia strony żony i teściów on dba by jego córka jadła zdrową i pełnowartościową żywność i unikała w ten sposób chorób, a żona i teściowie korumpuja córkę słodyczami i chipsami: i potem się dziwia, że mała tyle choruje... Sądy przez niego wydawane nie dotyczyły tylko osobistych problemów, ale odnosiły się także do bardziej ogólnych zagadnień: ludzie urodzeni $w$ mieście nie moga się zrozumieć z tymi urodzonymi na wsi. Żona to pochodzi z Łodzi, ona wolataby, żebym $w$ fabryce pracowat czy zaczą pryskać $i$ dużo produkować. Nie rozumie zupetnie o co mi chodzi $w$ życiu, że to jest praca petna sensu, że tylko produkując ekologiczna żywność, możemy mieć zdrowe dzieci, zdrowe spoteczeństwo...

Widziałem człowieka z misją, który chce ciężko pracować na utrzymanie swej rodziny, równocześnie godząc pracę $\mathrm{z}$ wyznawanymi wartościami, produkując i rozprowadzając zdrową żywność; człowieka, dla którego pieniądze były ważnym, lecz nie nadrzędnym stymulatorem działania. Dla mojego znajomego produkcja żywności ekologicznej była wyborem nie tyle technologicznym, co etycznym - klientów trzeba traktować tak samo jak własną rodzinę, nie można sprzedać im tego, czego samemu by się nie zjadło. Wreszcie dostawca opowiadał mi również o swych praktycznych doświadczeniach z wykonywania owego zawodu: gdybym nie zacząt się zajmować 
przetwórstwem to bym dawno już byt bankrutem, bo by dużo warzyw się marnowato. Trzeba przetwarzać, aby wszystko dało się spożytkować $i$ sprzedać.

Wówczas w głowie zaczął mi się rysować pomysł stworzenia socjologicznego portretu rolników ekologicznych, zrozumienia ich światopoglądu i wyborów życiowych, jak i praktycznych realiów ich funkcjonowania we współczesnej Polsce i Unii Europejskiej. Nie ukrywam, iż zająłem się badaniem eko-rolników motywowany sympatią do nich iw znacznym stopniu identyfikacją $\mathrm{z}$ ideałami ekologii. Choć dążę $\mathrm{w}$ toku mej pracy do możliwie jak największej intersubiektywności, wykazania dystansu wobec własnych poglądów i wartości, zaznaczam, iż mój afirmatywny stosunek do rolników ekologicznych mógł wpłynąć na sposób prezentacji zagadnień. Uważam, że o uczciwości intelektualnej świadczy jasne określenie swoich sympatii, jeśli takie odczuwamy a nie pozorowanie sterylnego, obiektywnego stosunku badacza wobec badanej rzeczywistości. Tym samym chciałbym, aby moja praca stała się kolejnym elementem wspomagającym zrozumienie tej grupy społeczno-zawodowej przez ogół społeczeństwa. Mam również nadzieję, iż niniejsza praca przyczyni się do rozwoju rolnictwa ekologicznego w Polsce, nie tylko poprzez wskazanie różnego rodzaju praktyk rolników i instytucji wspierających ten sektor, ale także jemu szkodzących.

Rolnictwo ekologiczne jest zjawiskiem złożonym. Z jednej strony rolnicy ekologiczni mogą być postrzegani jako mniej lub bardziej zorganizowany ruch społeczny, posiadający pewną misję i ideologię. Rolnictwo ekologiczne jest bowiem ściśle związane z ruchem ekologicznym będącym jednym z najbardziej znanych nowych ruchów społecznych. $Z$ drugiej strony, rolnictwo ekologiczne jest formą zawodu, sposobem zarabiania na życie. Nie tylko w Polsce obserwujemy proces profesjonalizacji w tej sferze gospodarczej. Zajęcie, które pierwotnie było pasją, musi stać się źródłem utrzymania: produkcja dla rodziny i przyjaciół musi stać się produkcją rynkową. W związku z powyższym kategoria, która najlepiej obrazuje ów stan pomiędzy ruchem społecznym a grupą zawodową jest pojęcie świata społecznego, które poddałem szerszej charakterystyce w rozdziale metodologicznym.

W przypadku Polski na krajobraz rolnictwa ekologicznego wpłynęło w znaczący sposób wstąpienie Polski do Unii Europejskiej, które zaowocowało gwałtownym, bo trzykrotnym wzrostem liczby gospodarstw ekologicznych. Za przyczynę takiego stanu rzeczy niejednokrotnie wskazuje się atrakcyjne dopłaty, jakie mogły pozyskać osoby zakładające gospodarstwo oparte na rolnictwie ekologicznym. Moim było poznanie 
profesji oraz misji, jaką mają współcześni polscy rolnicy ekologiczni, zarówno ci z długoletnim stażem, jak i ci, którzy w ciągu 4 ostatnich lat zdecydowali się na metody ekologiczne. Postanowiłem zastosować jak najmniej inwazyjne, jakościowe techniki badawcze, pozwalając im własnymi słowami opowiedzieć o tym, co robią i jaki jest tego cel.

Wyłaniające się podczas badania dane pozwoliły na sformułowanie następującej hipotezy: doświadczeni rolnicy są skłonni podkreślać kluczowe znaczenie misji i ideologii ekologicznej w swym pojmowaniu eko-rolnictwa, podczas gdy wśród świeżo upieczonych eko-rolników można znaleźć przypadki rolników dotacyjnych - ludzi motywowanych rachunkiem ekonomicznym zysków i strat, w niewielkim stopniu świadomych całej ideologicznej nadbudowy wykonywanej przez nich profesji. Niemniej jednak badania wskazały, że doświadczeni rolnicy musieli podjąc się procesu dostosowywania własnej misji do rynkowych realiów, podczas gdy nowi coraz bardziej przekonywali się, iż wiara w słuszność niekonwencjonalnych metod, takich jak kalendarz księżycowy, czy wysokie kryteria etyczne są warunkami sine qua non tego specyficznego biznesu. Przy rozpatrywaniu tego fenomenu postanowiłem nawiązać do kategorii zawodu i powołania. Chociaż tytuł pracy może sugerować pewną dychotomię, to w rzeczywistości, której istotą jest dynamizm i nieustanne zmiany, mamy jednak do czynienia z procesami, co sprawia, że wszyscy rolnicy ekologiczni znajdują się pomiędzy zawodem, rozumianym jako działanie zorientowane na korzyści ekonomiczne, i powołaniem, rozumianym jako służenie wyższym celom niż osiągnięcie korzyści materialnych. Znamienne, że klasyk socjologii Max Weber, autor głośnych esejów Polityka jako zawód i powołanie oraz Nauka jako zawód i powołanie, w oryginalnej niemieckiej wersji posługiwał się terminem Beruf oznaczającym łącznie zawód i powołanie (Politik als Beruf). Zatem użycie dwóch terminów o różnym zakresie semantycznym spowodowane zostało brakiem pojęcia, które stanowiłoby satysfakcjonujący odpowiednik niemieckiego słowa.

Jednak niektórzy spośród moich respondentów doskonale łączyli obie wspomniane wyżej sfery związane $\mathrm{z}$ rolnictwem ekologicznym. Jeden z nich, młody stażem eko-rolnik, ujął to w następujący sposób: rolnictwo ekologiczne to po prostu zawód z misją. Ten sam rolnik zaproponował bardzo trafną metaforę decyzji o przejściu na metody ekologiczne jako, zawarcia małżeństwa: Jeśli chcemy się ożenić z kobieta to powinniśmy ją kochać, bo inaczej sprowadzimy na siebie nieszczęście, 
podobnie z ekologia powinniśmy ją kochać, bo inaczej będziemy się tylko męczyć. A jeśli ja pokochamy to doczekamy się brylantynowych godów. Inni rolnicy wskazywali z kolei na trudności związane z rozwodem z ekologią. Podobnie jak zerwanie małżeństwa jest obwarowane licznymi instytucjonalnymi przeszkodami (np. wymóg procesu sądowego, konieczność upublicznienia prywatnych kłopotów), także rezygnacja z metod ekologicznych wiąże się z barierami, w tym przede wszystkim finansowymi, np. wymagania obejmują zwrot dopłat przydzielonych $\mathrm{w}$ ciągu ostatnich trzech lat. Dlatego decyzja o przejściu na ekologię nie powinna być podejmowana pochopnie.

Badania rolników ekologicznych przeprowadziłem głównie za pomocą metod jakościowych. Dane ilościowe dotyczące skali i struktury rolnictwa ekologicznego w Polsce pochodzące z Inspekcji Jakości Handlowej Artykułów Rolno - Spożywczych (IJHARS) wykorzystałem $\mathrm{w}$ analizie $\mathrm{w}$ rozdziale III. Trzon pracy stanowi 27 wywiadów narracyjnych i swobodnych, przeprowadzonych $\mathrm{z}$ rolnikami i rolniczkami ekologicznymi na obszarze całej Polski w okresie od listopada 2005 do maja 2007. Siedem wywiadów przeprowadziłem z kobietami, z których trzy prowadziły gospodarstwo samotnie. Najczęściej spotykanym typem ekologicznych gospodarstw rolnych jest prowadzone przez małżeństwa gospodarstwo rodzinne, w którym istnieje dość tradycyjny podział pracy. Mężczyzna wykonuje większość prac gospodarskich, podczas gdy kobieta $\mathrm{w}$ większym stopniu poświęca się prowadzeniu domu i pracom księgowo-dokumentacyjnym. Jednakże, wśród przebadanych przeze mnie rolników znalazły się także rozwiedzione kobiety, które samodzielnie prowadzą gospodarstwo. Zależało mi bowiem, aby uwzględnić również ich perspektywę oraz doświadczenia - co miało na celu zapewnić jak najwierniejszy opis rzeczywistości, a jednocześnie uwzględnienie wymiaru gender.

Wywiady prowadzilem głównie $\mathrm{w}$ dwóch miejscach: w specjalistycznych sklepach z żywnością ekologiczną i w gospodarstwach rolników. Kilkakrotnie spotkałem się z odmowami udzielenia wywiadu motywowanymi brakiem czasu. Z tego też powodu odbywały się one niejednokrotnie $\mathrm{w}$ samym sklepie lub w zaparkowanym pod sklepem samochodzie moich rozmówców. Jedynie dwoje rolników zaproponowało mi rozmowę w bardziej sprzyjającym miejscu: herbaciarni i barze. Pozostałe wywiady zostały przeprowadzone w gospodarstwach rolników, co rodziło przyjazną atmosferę, pozbawioną pośpiechu dzięki czemu rozmówcy byli bardziej skłonni do udzielenia wyczerpujących odpowiedzi na pytania. Niemniej, 
niemal zawsze spotykałem się z życzliwym przyjęciem ze strony rolników, i częste były sytuacje, gdy rolnik, który zastrzegał, iż nie ma czasu lub że zgadza się tylko na 15 minut, potrafił rozmawiać ze mną spokojnie ponad godzinę. Niejednokrotnie obserwowałem także żywe zainteresowanie moimi badaniami ze strony rolników, którzy traktowali udzielenie wywiadu jako działanie służące rozwojowi i promocji eko-rolnictwa. Często też byłem traktowany jako źródło informacji, pytania o zdania innych rolników, skalę rozwoju rolnictwa ekologicznego czy wyniki badań, odbierałem jako wskaźnik istotności moich badań dla badanej grupy.

Oprócz wywiadów indywidualnych, zastosowana została również obserwacja uczestnicząca poprzez wzięcie udziału $\mathrm{w}$ pielgrzymce i spotkaniach rolników ekologicznych. Dzięki uczestnictwu w tych wydarzeniach mogłem bezpośrednio dostrzec występujące areny sporów i czynniki składające się na ideologię i grupową tożsamość badanej grupy.

Inną zastosowaną techniką jakościową była analiza treści dyskursu ekorolnictwa. Tutaj najważniejszą rolę miała analiza zawartości i ideologii czasopisma Eko Arka, jak i publikacji jego redaktora Zbigniewa Przybylaka. Eko Arka jest jedynym niezależnym od struktur państwowych i samorządowych, ogólnopolskim magazynem rolników ekologicznych, bezsprzecznie najbardziej poczytnym.

Lucjan Kocik (2000), wybitny socjolog wsi z Uniwersytetu Jagiellońskiego wyraził opinie, iż łączenie różnych technik jakościowych jest odpowiednim podejściem do badania rzeczywistości społecznej wsi, gdyż mamy tu do czynienia "ze społeczno-kulturowymi catościami" (s. 16-19). Podzielam opinię profesora Kocika (ibidem), iż to metoda powinna się przystosować do przedmiotu, gdyż "metodycznie czyste" zbieranie danych (tzw. clean research) nie jest koniecznq ani wystarczajacca gwarancja uzyskania wyników rzetelnych pod względem naukowym (s. 16). Kocik podziela opinię znanego badacza wsi Ch. Giordano (2000), która zakłada, iż społeczności rolnicze są szczególnie trudną grupą do zbadania, stosując tradycyjne techniki badawcze, postulując jednocześnie łączenie technik socjologicznych z antropologicznymi (s. 16-17). Wybór technik jakościowych $\mathrm{w}$ tej pracy został podyktowany chęcią dotarcia do samego sedna rzeczywistości empirycznej. Należy również nadmienić, iż mam świadomość niedoskonałości narzędzia badawczego przejawiających się m.in. w pytaniach ankietowych sugerujących odpowiedzi, jak również nieuwzględnienia całego spectrum zagadnień związanych z eko-rolnictwem. Uznałem, ze odpowiedzi na fundamentalne pytania: dlaczego?, po co? i jak?, mogą 
wypłynąć jedynie z rozmowy pozbawionej wstępnych założeń badacza, który wie lepiej. Ponadto przyjęta została przeze mnie zasada badań jakościowych, która zaczerpnięta jest, z terenu etnografii, a mianowicie reguła zachowywania pojęć typu emic, czyli naturalnego języka i kategorii używanych przez badanych rolników, przejawiająca się m.in. $\mathrm{w}$ rezygnacji z potrzeby ich estetyzacji czy teoretycznego przeformułowania, co miało na celu jak najwierniejsze zobrazowanie rzeczywistości rolnictwa ekologicznego.

Fascynacja eko-rolnictwem była przyczynkiem do przygotowania w 2007 pracy magisterskiej poświęconej tej tematyce. Tę właśnie pracę, po dokonaniu niezbędnych aktualizacji i poprawek, oddaję w dwa lata później do druku w Przeglądzie Socjologii Jakościowej. Tematowi zmian, które zaszły w obszarze eko-rolnictwa od momentu ukończenia pracy w czerwcu 2007 poświęciłem zamieszczony na końcu pracy esej: Post scriptum. Między ogródkiem pani Obama a groźbą likwidacji, czyli co zmieniło się w ciągu dwu lat od ukończenia badań?

\section{Podziękowania}

Pragnąłbym, przede wszystkim, bardzo serdecznie podziękować mojemu promotorowi, prof. dr hab. Krzysztofowi Koneckiemu, za dobrą współpracę, cierpliwość, konsultacje, wsparcie i wnikliwą korektę.

Dziękuję bardzo za wsparcie Fundacji im. Heinricha Boella, Przedstawicielstwu $\mathrm{w}$ Polsce. Udział $\mathrm{w}$ programie stypendialnym z zakresu zintegrowanego rozwoju obszarów wiejskich umożliwił mi głębsze poznanie realiów działalności społecznej na wsi i problematykę rozwoju wsi, jak i zapewnił środki materialne na prowadzenie badań związanych z częstym przemieszczaniem się po obszarze całej Polski.

Dziękuję również prof. dr hab. Konradowi Waloszczykowi i pani Dorocie Meterze za udostępnione mi materiały i uwagi.

Specjalne podziękowania należą się mej koleżance Kamilli Szewczyk, która pomogła mi w organizacji oraz poprawie wydajności mej pracy.

Również chciałbym serdecznie podziękować wszystkim rolnikom i rolniczkom ekologicznym, którzy poświęcili swój czas na rozmowę ze mną. Mam nadzieję, że praca ta zainteresuje także ich.

Moja praca uzyskała w 2008 roku I nagrodę w konkursie im. prof. Witolda Kuli na najlepsze prace magisterskie $i$ doktorskie poświęcone ciekawym $i$ wartym 
propagowania, inicjatywom spoteczno-ekonomicznym z zakresu historii, socjologii, prawa, ekonomii idziedzin im pokrewnych. Wspomniany konkurs przeprowadził Bank DnB NORD w porozumieniu z Wydziałem Nauk Ekonomicznych Uniwersytetu Warszawskiego. Serdecznie dziękuję organizatorom konkursu i jurorom za dostrzeżenie znaczenia podjętego przez mnie tematu. Dziękuję za cierpliwość oraz zaangażowanie $\mathrm{w}$ edycję, korektę $\mathrm{i}$ opracowanie graficzne zespołowi PSJ: Izabeli Ślęzak, Annie Kacperczyk, Kamilowi Głowackiemu i Jakubowi Niedbalskiemu. 


\section{Metodologia badań własnych}

\section{Teoria ugruntowana jako opcja paradygmatyczno - metodologiczna}

Moje badania miały z samego założenia charakter eksploracyjny. Zaczynając badania miałem niewielką wiedzę na temat badanej grupy społecznej. W pierwszej fazie badań pomocnymi okazały się wywiady nieformalne - luźne, nierejestrowane za pomocą dyktafonu rozmowy z rolnikami, będącymi dostawcami łódzkich sklepów z żywnością ekologiczną. Równocześnie zapoznawałem się z prasą skierowaną do rolników ekologicznych i publikacjami poświęconymi tej tematyce. Po dokonaniu wstępnego rekonesansu, przeszedłem do bardziej usystematyzowanych badań, stosując obserwację (również uczestniczącą), wywiady narracyjne i swobodne, analizę treści.

Jak podkreśla Krzysztof Konecki (2000), użycie określonej techniki nie jest równoznaczne zprzyjęciem określonego paradygmatu, gdyż podziaty paradygmatyczne sięgaja głębiej poza techniki używane $w$ badaniach $i$ dotycza głównie założeń ontologicznych $i$ epistemologicznych leżących u podstaw określonych perspektyw teoretycznych (s. 23). Nie istnieje bowiem sprzeczność pomiędzy samymi technikami uznawanymi za ilościowe (kwestionariusze, analizy statystyczne, cenzusowe, itd.), jak i technikami jakościowymi (wywiady swobodne, obserwacje uczestniczące, dokumenty osobiste). Uznaną procedurą metodologiczną jest triangulacja technik, czyli stosowanie różnego rodzaju metod, równocześnie tych uznawanych za jakościowe i ilościowe. Zdaniem Koneckiego (ibidem), najlepiej dla rzetelności badań jest, gdy używa się do zbadania danego problemu wiele technik. Kontroluja się one nawzajem, pozwalając spojrzeć na dane zjawisko z wielu punktów widzenia. Jak konstatują Miles i Huberman (2000), triangulacja jest przede wszystkim droga uzyskiwania wyników - poprzez wyshuchiwanie lub przyglądanie się wielu przypadkom, pochodzącym z różnych źródet przy użyciu różnych metod i przez wzajemne dopasowanie jedynych wyników do drugich, do których należy je dopasować (s. 277).

Sprzeczność pojawić się może dopiero na poziomie paradygmatów, czyli sposobów ujmowania rzeczywistości (Konecki 2000: 17) lub fundamentalnych modeli czy układów odniesienia, których używamy, by uporzqdkować nasze obserwacje i rozumowanie (Babbie 2003: 56). Paradygmat obejmuje przede 
wszystkim cel badań rozumiany jako odpowiedź na pytanie: po co?, jak i ogólne założenia ontologiczne i epistemologiczne dotyczące badanej rzeczywistości. Thomas P. Wilson (1973) wyróżnia dwa typy paradygmatów: normatywny i interpretatywny (s. 57). Pierwszym jest paradygmat normatywny, który reprezentuje bardziej statyczną wizję działania jako czynności powtarzalnej wynikającej z pierwotnych wobec aktora zewnętrznych oczekiwań otoczenia i wewnętrznych dyspozycji aktora (np. postaw, warunkowanych odpowiedzi), które nazywane są rolami. Wszelkie nietypowe zjawiska czy zachowania funkcjonujące wedle paradygmatu normatywnego badacz uznaje za rodzaje dewiacji, dysfunkcji, czyli odejścia od normy, bądź odgrywanej w systemie społecznym funkcji. Rzeczywistość społeczna w omawianej perspektywie jest dość przewidywalna, podobnie jak zachowania jednostki, działającej wedle ściśle określonych, powtarzalnych, pierwotnych wobec niej wzorców. Paradygmat ten związany jest z tradycją Emila Durkheima, dominującym w powojennej socjologii nurtem strukturalnego funkcjonalizmu i nazwiskiem Talcotta Parsonsa. Warto zwrócić uwagę, że Wilson (1973) zalicza do niej również niektóre nurty symbolicznego interakcjonizmu, które zakładają istnienie pewnych, trwałych identycznych odpowiedzi aktorów na określone symbole, co zakłada dedukcyjną drogę objaśniania działań jednostek (s. 69). Alternatywna wizja rzeczywistości reprezentowana jest przez paradygmat interpretatywny, obejmujący symboliczny interakcjonizm (H. Blumer, B. Glaser i A. Strauss, H. Becker) czy etnometodologię (H. Garfinkiel). Wilson podkreśla, że definicje sytuacji nigdy nie mogą tu być ostateczne i zawsze podlegają zmianom. Wilson podkreśla, że autentycznie interpretatywnej metodologii dostarcza etnometodologia H. Garfinkela, która zakłada indeksykalność (indexality), wedle której każde zjawisko współokreśla i zmienia służące do rozumienia go wzory (underlying patterns). Tradycja ta powstała w opozycji do normatywnej wizji rzeczywistości i akcentuje dynamiczny i w bardzo ograniczonym zakresie, przewidywalny charakter społecznego świata wynikający z twórczego potencjału jednostek, które każdorazowo mogą przypisać inne znaczenie swym działaniom. Oznacza ona humanistyczną reakcję na socjologię dążącą do upodobnienia się do nauk ścisłych z ideałami maksymalnej, matematycznej precyzji pomiaru, twardego udowodnienia lub odrzucenia hipotez. Istotą wizji interpretatywnej jest zatrzymanie się nad fenomenem spotkania człowieka z człowiekiem, zwanego najczęściej interakcją ze względu na cechę wzajemności i dotarcie do sposobów, w jaki ludzie budują sens i opis siebie, innych czy 
interesujących badacza zjawisk. Rzeczywistość jest, wedle tego paradygmatu, zwanego niekiedy społecznym konstruktywizmem, tworzona poprzez jednostkowe percepcje, człowiek jest twórcą własnej roli, a nie abstrakcyjną jednostką ludzką. Właśnie $\mathrm{w}$ tej perspektywie $\mathrm{w}$ centrum zainteresowania badaczy leży społeczne wytwarzanie znaczenia. Opcja ta oznacza pewien ukłon w stronę wiedzy potocznej, lecz każda z składających się na paradygmat interpretatywny teorii wypracowuje własną metodologię, zarazem zostawiając badaczom margines wolności.

Najbliższą mi wizją rzeczywistości społecznej jest symboliczny interakcjonizm, zwłaszcza w ujęciu Herberta Blumera (1975). Wedle niego, jednostka oddziałuje na obiekty za pomocą przypisywanym im znaczeniom, interakcje między ludźmi i ludźmi i fenomenami są zapośredniczone przez symbole, subiektywne interpretacje. Człowiek jest podmiotem aktywnym, twórcą znaczeń, świadomie oddziałuje na obiekty duchowe, materialne i społeczne (s. 76). Ponadto, znaczenia są konstruktem społecznym tworzonym w procesie społecznej interakcji, co wpływa na podlegający nieustannym negocjacjom. zmienny, dynamiczny charakter znaczeń (Blumer 1969: 10-12). Interakcja posiada pewną autonomiczną wartość wobec partnerów komunikacji, którzy nie w pełni kontrolują jej zakres. Interakcja jest nieustannie konstruowana $\mathrm{w}$ ramach procesu wzajemnego dopasowywania działań i znaczeń poprzez podejmowanie roli innego tzw. role-taking (Konecki 2005: 166).

Ważną inspiracją teoretyczną był dla mnie jeden z klasyków socjologii Georg Simmel (1858-1918), autor jak dotąd mało docenianej perspektywy obserwacji interakcji człowieka z przyrodą. Simmel był pionierem mikrosocjologii, badał sposoby, w jakie jednostki wchodzą we wzajemne interakcje, wywierając znaczący wpływ na amerykańskich prekursorów symbolicznego interakcjonizm G. H. Meada i C. H. Cooleya (Babbie 2003: 60). Simmel w swych pracach uwzględnił interakcje między światami człowieka i przyrody na wiele lat przed społecznymi konstruktywistami, uznającymi jedynie ludzkie interpretacje świata przyrody i realistami, uznającymi środowisko naturalne jako realną, bezpośrednią informację, niezależną od ludzkich wysiłków interpretacyjnych (Gross 2001). Ujmował społeczeństwo jako sieć wzajemnych interakcji zarówno pomiędzy ludźmi, jak i pomiędzy ludźmi i światem przyrody. Simmel dostrzegał dynamiczny, procesualny charakter interakcji i rzeczywistości społecznej, częstość interakcji decydowała o ich typowości i ich znaczeniu dla badanej zbiorowości. Socjologia wedle niego miała być studiowaniem owych interakcji - form i rodzajów socjetyzacji, tworzenia 
społeczeństwa, uspołeczniania (Vergesselchaftung). Simmel zauważyl, iż człowiek nieustannie współpracuje albo rywalizuje z Przyrodą. Kategorie sztuczności (produktu człowieka) i naturalności, które należą do naszego potocznego języka i doświadczenia powinny być raczej uznane za pewne ścierające się lub uzupełniające tendencje. Przyroda, jako podmiot nigdy nie wyzbyła się praw do dzieł człowieczych, nie szanowała granic, jakie człowiek mógłby chcieć jej postawić. Na przykładzie ruin czy starych nagrobków widzimy ekspansywną działalność przyrody, prowadzącą do tego, iż owe symbole ludzkiej kultury stają się własnością ludzko-przyrodniczą. W tworach ludzkich, takich jak ogród, ciągle funkcjonuje naturalna tendencja Przyrody do wzrostu i upadku i trudno uznać końcowy produkt za kulturowy, ludzie dają impuls do samoczynnego rozwoju Przyrody, ogrodnik to budziciel Przyrody. Stąd podział na naturę i kulturę wydawał się niemieckiemu socjologowi mało adekwatny i dokładny. W rzeczywistości mamy do czynienia z nieustannymi grami ludzkiej celowości i naturalnej nieprzewidywalności. Aby lepiej zrozumieć istotę owych gier, Simmel proponował gotowość do przestawiania perspektyw pomiędzy subiektywnym ludzkim działaniem, a obiektywnym, niezależnym od ludzkich interpretacji, działaniem Przyrody. Socjolog powinien umieć dostrzegać momenty graniczne, w których należy przejść z pierwszej perspektywy w drugą, skupić się na opisie obiektywnych, nielinearnych działań Przyrody jako członka ludzkiej wspólnoty aby powrócić do subiektywnych interpretacji analizowanych ludzi. Nieprzewidywalność Przyrody to jej niepojęta kreatywność, która może być źródłem człowieczego zachwytu lub zakłopotania. Perspektywa Simmla wyprzedzała koncepcje ekologiczne, takie jak np. zarządzanie adaptacyjne (adaptive management Hollinga), dostrzegający stały dynamizm przyrody i wymagające od człowieka dużej elastyczności i przygotowania na niespodziewane. Przyjmując Simmlowską perspektywę, jesteśmy $\mathrm{w}$ stanie zrozumieć fenomen Przyrody jako podmiotu opatrzonego antropogennymi cechami (ziemia choruje, Przyroda odmawia wspótpracy), który pojawia się w narracjach eko-rolników, ludzi, którzy próbują świadomie współpracować z Przyrodą, licząc się z jej nieprzewidywalnością. Często stosowali eksperymenty by zbadać lub przewidzieć reakcję owej Partnerki.

W przypadku uwzględnienia Przyrody jako aktora interakcji dochodzi do przekroczenia (transgresji) ram symbolicznego interakcjonizmu w jego tradycyjnym wydaniu G. H. Meada, wedle której język werbalny i komunikacja werbalna są podstawowymi elementami kształtowania jaźni i wspólnoty (Por. Konecki 2005: 183). 
Krzysztof Konecki (2005) w swych badaniach interakcji ludzi i zwierząt doszedł do wniosku, iż w przypadku badanej rzeczywistości zaistniał transgresywny kontekst interakcji czyli kontekst przestrzeni interakcyjnej dzielacej i taczacej zarazem dwa światy: światy natury i świat typowo ludzki (s. 185). Istotą rozpoznania owego kontekstu było uwzględnienie znaczenia świata przyrody, cielesności, emocjonalności, komunikacji niewerbalnej, nie zawsze możliwych do opanowania za pomoca racjonalnej myśli i językowej "magii" (Konecki ibidem). Perspektywa transgresywna jawi mi się jako przydatna w kontekście badania świata społecznego eko-rolników, zrozumienia mistycznych przeżyć z udziałem siły wyższej i interakcji z Przyrodą, która przemawia do nich w bezpośredni, pozasymboliczny sposób.

Tożsamość, jak zauważa Zbigniew Bokszański (2005), jest pojęciem oryginalnie zaczerpniętym z matematyki i chcącym wyrazić identyczność i związaną z nią jednoznaczność, stałość, statyczność (s. 30-33). Statyczne ujęcie tożsamości jako właściwego pewnej grupie względnie stałego zbioru cech i atrybutów kłóciło by się z postulowanym przyjęciem paradygmatu interpretatywnego. Szkoła chicagowska, do której są zaliczani twórcy symbolicznego interakcjonizmu (H. Blumer) i teorii ugruntowanej (A. Strauss) opowiadała się za procesualnym ujęciem tożsamości aktorów społecznych (Bokszański ibidem: 33). W tej perspektywie mamy do czynienia nie ze stałą tożsamością, lecz dynamicznym procesem tworzenia tożsamości, będącym $\mathrm{w}$ istocie procesem stawania się rolnikiem ekologicznym. Podobny punkt widzenia przedstawia Aldona Jawłowska (2001), deklarując:

\begin{abstract}
Bliższe sq mi sposoby definiowania tożsamości, wedle których pojęcie to obejmuje raczej pewien proces niż stan będący rezultatem tego procesu. Akcent pada tu na pytanie, $w$ jaki sposób tożsamość się tworzy i zmienia, a nie na to, czym jest. Takie podejście do problemu tożsamości zawiera założenie, iż wysilek samookreślenia nie zostaje uwieczniony ostatecznym wpisaniem się $w$ jakiś rodzaj kulturowego porzadku, a jednostka lub grupa trwa $w$ stanie permanentnego braku wyraźnie określonej tożsamości dającej poczucie stabilizacji i bezpieczeństwa (s. 54).
\end{abstract}

Procesualne ujęcie tożsamości, które znajdujemy u Jawłowskiej i symbolicznych interakcjonistów wydaje mi się najbardziej odpowiednie do badania polskich rolników ekologicznych, grupy o stosunkowo krótkim rodowodzie i przechodzącej ważne przeobrażenia. Dynamiczne ujęcie tożsamości nawiązuje do tzw. studiów nad stawaniem się (on becoming studies), których zadaniem jest 
ukazanie kolejnych etapów, które przechodzi jednostka zostając członkiem określonej zbiorowości, np. palaczy marihuany (Becker 1953), załogi zakładu przemysłowego (Konecki 1992), nauczycielem akademickim (Marciniak 2005) czy poetą (Ślęzak 2009).

Zdecydowałem się użyć głównie technik jakościowych, gdyż umożliwiają one wierną rekonstrukcję perspektywy badanych, niejako od wewnątrz, stosując właściwe im zwroty, pojęcia typu emic. Uznałem, iż stosowanie tych właśnie technik jest jednocześnie wyrazem najwyższego szacunku dla badanych i ich wiedzy. Jak słusznie zauważa Earl Babbie (2003) techniki jakościowe pozwalają wychwycić subtelności komunikacji i pewnych wydarzeń, które $w$ inny sposób nie mogłyby być przewidziane ani zamierzone (s. 242). Techniki ilościowe są bardziej odpowiednie do badania skali występowania określonych zjawisk, zaś techniki jakościowe w większym stopniu sprzyjają głębszemu zrozumieniu badanych światów i fenomenów. W tym sensie na potrzeby określenia skali polskiego rolnictwa ekologicznego i zachodzących w niej przemian posłużyłem się danymi ilościowymi. Służyły mi one jednak tylko jako niezbędne określenie wielkości badanego społecznego świata, którego charakteryzacji i objaśnienia dokonałem stosując techniki jakościowe.

Wywiad narracyjny jest techniką, która umożliwia badanym pełną wypowiedź własnymi słowami o swoim życiu. Technika ta jawi się jako najmniej manipulująca w sensie ukierunkowywania wypowiedzi respondenta, dostarczania mu tropów dotyczących tego, co badacz mógłby chcieć usłyszeć. Oczywiście w przypadku wywiadu narracyjnego czynnikiem interweniującym może być tendencja do ubarwiania opowieści o własnym życiu, celem osiągnięcia efektu atrakcyjnej autoprezentacji. Nie znam techniki całkowicie sterylnej umożliwiającej całkowite oddzielenie badacza od empirycznej rzeczywistości, status zewnętrznego, niezaangażowanego obserwatora, niemniej $\mathrm{w}$ przypadku wywiadu narracyjnego wpływ badacza na wypowiedzi respondenta wydaje się być relatywnie niski.

Niemniej, przeprowadziłem więcej wywiadów swobodnych niż narracyjnych, często bowiem mimo stworzenia atmosfery zaufania respondent ograniczał opowieść o swoim życiu do kilku zdań, konstatacji kilku kluczowych wydarzeń, unikając snucia opowieści. W takich wypadkach posiłkowałem się licznymi pytaniami, decydując się na przeprowadzenie wywiadu swobodnego. 


\section{Charakterystyka podstawowych zatożeń i procedur badawczych teorii ugruntowanej}

Teoria ugruntowana, krytyczna teoria socjologiczna, rozumiejąca badanie społeczne jako interakcję między badaczem a obserwowanym światem społecznym, została stworzona przez Barney'a Glasera oraz Anselma Straussa i sprawdzona po raz pierwszy w badaniach instytucji opieki zdrowotnej (1967). Teoria ugruntowana może być zaliczana do paradygmatu interpretatywnego i właściwe jej jest procesualne ujęcie rzeczywistości społecznej (Konecki 2000: 39). Omawiana teoria nie aspiruje do bycia teorią całości społeczeństwa, ani do ograniczania się do studiowania mikrogrup, bada ściśle wyodrębniony obszar empiryczny, stanowiąc egzemplifikację teorii średniego zasięgu (Merton 2002: 61-93). Skromniejsze aspiracje tej teorii podyktowane były faktem, iż powstała ona w opozycji do praktykowanego przez niektórych teoretyków nauk społecznych zmierzania w kierunku ekspansji utartych schematów teoretycznych na coraz szersze obszary życia (Konecki 2000: 26). Zaleceniem teorii ugruntowanej jest utrzymywanie w trakcie badania otwartość umysłu na nowe zjawiska, tworząc klimat serendipity - kontekstu odkrycia.

Glaser i Strauss poddali ostrej krytyce paradygmat normatywny, związaną z nim zaczerpniętą z nauk ścisłych koncepcje badań jako weryfikacji hipotez. Krytykowali również całą retorykę weryfikacyjną, stosowaną również przez reprezentantów technik jakościowych, zmierzającą do stawania hipotez, sprawdzania, testowania, stosowania reguty większości (Konecki 2000: 27). Proponowaną przez nich alternatywą był dynamiczny i indukcyjny proces budowana teorii i powstała na jego użytek retoryka generowania teorii. Teoria ugruntowana stawia sobie za cel przewidywanie, wyjaśnianie i rozumienie zachowań spolecznych i ujmowanie ich w języku zrozumiałym dla znaczących laików - uczestników badanego obszaru świata (Konecki ibidem: 28). Cechami teorii powinno być dostosowanie do bezpośrednio zebranych danych, istotność czyli doniosłość dla badanego obszaru, modyfikowalność - pewna elastyczność zapewniająca podatność na niezbędne przeformułowania, możliwość odniesienia teorii do obszarów innych niż bezpośrednio badany. Ponadto, teoria powinna pracować czyli wyjaśniać i przewidywać, najlepszym sprawdzianem jej pracy byłby sprawdzian ze strony badanych, zgodność z ich odczuciami (Konecki ibidem: 27-28). Podstawowymi składnikami teorii ugruntowanej są kategorie czyli istności i jakości wyróżnione 
w procesie różnicowania rzeczywistości empirycznej, ich cechy zwane własnościami kategorii, a także hipotezy powstałe w trakcie badań i obserwowane in vivo (Konecki ibidem: 29). W toku analizy danych szczególnie ważne znaczenie ma generowanie pojęć uwrażliwiających, niosących potencjał przybliżenia badacza do istoty zjawiska w ich naturalnym przebiegu (Blumer 1969: 42-46).

Podstawowymi procedurami teorii ugruntowanej, zapewniającymi synchroniczny model badań z hipotezami budowanymi na podstawie wyłaniających się z rzeczywistości empirycznej kategorii są metoda teoretycznego pobierania próbek i permanentnego porównywania (Por. Glaser; Strauss 1967: 45; Konecki 2000: 3031). Teoretyczne pobieranie próbek oznacza proces gromadzenia i kodowania danych celem generowania kategorii i opracowywania teorii w oparciu o postrzegane między nimi zależności. Porównywanie obejmuje poszukiwanie wspólnych właściwości dla różnych przypadków, porównywanie pojęć z innymi empirycznymi przypadkami, generując nowe teoretyczne właściwości pojęć i porównywanie różnych pojęć celem integrowania ich w stanowiące oparcie dla teorii hipotezy (Por. Konecki 2000: 31). Koniec procesu pobierania danych następuje w momencie teoretycznego nasycenia, czyli chwili, gdy socjolog zaobserwuje nieustanne pojawianie się podobnych przypadków, przeczuwając, iż sformułowane kategorie są wyczerpane (Por. Konecki ibidem: 31). W rozpoznaniu momentu nasycenia teoretycznego pomaga badaczowi obowiązek pisania not teoretycznych. Po przeprowadzeniu 27 wywiadów z rolnikami uznałem, iż doszło do nasycenia teoretycznego, gdyż poznałem taką różnorodność przypadków, że kolejne przypadki nie wniosły zmiany do tworzonych schematów eksplanacyjnych.

W opinii Krzysztofa Koneckiego (2000), metodologia teorii ugruntowanej ukazuje, że badania jakościowe nie sq impresjonistyczna, swobodna twórczościa literacko uzdolnionego badacza, a sa żmudna, systematyczna, kontrolowana $i$ "obiektywna" ( $w$ nie mniejszym stopniu od procedur ilościowych) metodologia badawczą (s. 32). Głównymi narzędziami dyscyplinującymi badacza jest kodowanie i pisanie not teoretycznych. Można wyróżnić dwa zasadnicze typy kodowania: teoretyczne i rzeczowe, które obejmuje kilka rodzajów kodowania: otwarte, zogniskowane i selektywne (Konecki ibidem: 42; Ślęzak 2009: 39). Kodowanie otwarte dopuszcza przypisywanie etykiet fragmentom zebranego materiału empirycznego, dopuszczając dużą rolę kreatywności badacza, jednakże zalecając możliwie wierne trzymanie się terminów użytych przez interlokutora. Rezultatem 
tego etapu jest utworzenie kategorii i ich własności poprzez analizę materiału jakościowego Kodowanie otwarte stanowi pierwszą fazę, będącą podstawą dla dalszych faz. Następnym stadium procesu jest kodowanie zogniskowane, dążące do stwierdzenia wzajemnych relacji pomiędzy kategoriami i subkategoriami. Wedle paradygmatu kodowania, w tej fazie należy uwzględnić warunki przyczynowe, zjawisko - kategorię centralną, kontekst, warunki interweniujące, działania, strategie i techniki interakcyjne oraz konsekwencje (Konecki 2000: 49). Wspierającym narzędziem może być matryca warunków, pozwalająca dokonać poziomowania badanych fenomenów, przyporządkowując określone zjawiska np. do poziomu interakcji, grupy, kraju, areny międzynarodowej (Konecki ibidem: 50-51). Efektem omawianej fazy kodowania powinno być wyłonienie kategorii centralnej, stanowiącej niejako środek koła i jądro analizy. Następującą fazą jest kodowanie selektywne porządkujące materiał ze względu na ich istotność dla kategorii centralnej. Efektem kodowania rzeczowego jest ustalenie relacji i hierarchii między kategoriami. Budowie teorii służy kolejny etap - kodowanie teoretyczne - obejmujący generowanie teorii w oparciu o noty teoretyczne przygotowane w trakcie badań i opisane w teoretycznym języku refleksje badacza.

Ważną procedurą heurystyczną, współbrzmiącą $\mathrm{z}$ metodologią teorii ugruntowanej jest triangulacja. Pozwala ona na zwiększenie pewności, prawomocności i wiarygodności oraz możliwości uogólniania stworzonych w trakcie badań wniosków (Konecki ibidem: 95). Stosowanie wielości technik umożliwia uwzględnienie wielu punktów widzenia przy rozważaniu problemu badawczego (Hammerslay, Atkinson 2000: 219).

Norman Denzin wyróżnił cztery podstawowe typy triangulacji (wg Konecki 2000: 86):

1. triangulację danych czyli korzystanie z różnorodnych źródeł

2. triangulację badacza czyli dopuszczenie do badań niezależnych obserwatorów, celem kontroli badań i wniosków

3. triangulację teoretyczną czyli stosowanie różnych perspektyw teoretycznych do zinterpretowania pojedynczego zestawu danych

4. triangulację metodologiczną czyli użycie wielu metod dla zbadania pojedynczego problemu 
W niniejszym badaniu stosowałem przede wszystkim triangulację danych (wykorzystanie danych wywołanych w procesie badawczym, jak i danych zastanych), jak i triangulację technik zbierania danych (wywiady, obserwacja uczestnicząca, itd.).

\section{Zastosowane techniki badawcze}

\subsection{Wywiad swobodny}

Jak zauważył Krzysztof Konecki (2000) nie jest dziełem przypadku, iż słowo wywiad na gruncie języka polskiego oznacza też instytucję szpiegowania, bądź samo szpiegowanie (s. 178). Robiące światową karierę angielskie słowo interview znaczą proces substancjalnie różniący się od zwykłej sytuacji rozmowy. W tradycyjnych dziennikarskich i socjologicznych wywiadach mamy do czynienia z asymetryczna sytuacją, gdy zadający pytania rozdaje karty, kontroluje przebieg rozmowy, "wyciąga" informacje od swego rozmówcy, który jest w socjologicznym żargonie nazywany respondentem, czyli odwołując się do angielskiego respond, hiszpańskiego responder, "odpowiadaczem". Formalne wskazania zabraniają przeprowadzającym wywiad otworzyć się, podzielić się własnymi poglądami i odczuciami, ankieterzy są rejestratorami. Konecki (ibidem) zauważa w owej asymetrii, faktycznq hierarchię społecznq sytuacji wywiadu (s. 178), mówiąc wprost o stosunku podporządkowania. Zdaniem tego autora, w momencie zakończenia wywiadu, przepytywany jest uboższy o swoja prywatność i niezależność, jeśli udzielit jakichś szczególnych informacji o sobie, swoich pogladach politycznych, opiniach o pracy czy życiu prywatnym. Przepytujący jest wtaśnie o te informacje bogatszy (Konecki ibidem: 179).

Owa humanistyczna troska o dążenie do sytuacji równowagi w trakcie procesu wywiadu była mi bardzo bliska, zwłaszcza w sytuacji mojej sympatii do badanej grupy. Zdecydowałem się wybrać wywiad swobodny, zwany inaczej pogłębionym wywiadem etnograficznym i wywiad narracyjny jako podstawowe techniki badawcze. Wywiad narracyjny wymagał atmosfery spokoju i zaufania, a także pewnego otwarcia interlokutora, na które składa się radość płynąca z dzielenia się swym życiowym doświadczeniem, sprzyjające snuciu opowieści tendencje charakterologiczne. Zazwyczaj zakładałem, iż spróbuję przeprowadzić wywiad narracyjny, lecz świadom, iż moi rozmówcy mogą się spieszyć lub nie mieć ochoty dzielić się opowieścią o życiu, 
przygotowywałem pewną listę dyspozycji - zagadnień, o które ich pytałem. Pozostając wiernym paradygmatowi interpretatywnemu, prowadzilem wywiady swobodne o niskim stopniu standaryzacji. Wywiady swobodne odznaczają się nieformalnym, potocznym językiem, otwartością na zmiany i niespodziewane elementy pomijane w badaniach kwestionariuszowych. Ideałem tego wywiadu jest swobodna rozmowa, z zastrzeżeniem, iż badacz ogranicza swój udział w niej do sporadycznych wtrąceń i próśb o doprecyzowanie (Konecki ibidem: 169).

Pierwsze przeprowadzone przeze mnie wywiady swobodne miały charakter mało ukierunkowany, przeważały w nich pytania otwarte, służące spontanicznej eksploracji badanego obszaru, zachęcające do wielowątkowych wypowiedzi, tkania narracji (Por. Konecki 2000: 170; Przybyłowska 1978: 63-66). Późniejsze wywiady można by określić mianem ukierunkowanych, gdyż przystępując do nich miałem znacznie dłuższą listę poszukiwanych informacji, niemniej ciągle dominowały pytania otwarte i swobodny tok wypowiedzi. W sytuacji wywiadu przyjmowałem rolę osoby niekompetentnej $w$ spolecznie akceptowalnym stopniu (Babbie 2004: 329) czy, wedle odmiennego określenia, akceptowalnego ignoranta (Hammerslay, Atkinson 2000: 101), stawiając moich rozmówców w roli ekspertów, którzy mogą zostać moimi przewodnikami po mało znanym mi świecie.

Aby sytuacja wywiadu przypominała rozmowę, miałem zapamiętaną w głowie listę pytań i dopiero w momencie, gdy wyczerpały mi się pytania, zaglądałem do kartki, by upewnić się, że nie pominąłem ważnego wątku. Dbałem o to by moim rozmówcy czuli się komfortowo, na początku opowiadając im o sobie i celu badań, a po wyłączeniu dyktafonu pozostawałem do ich dyspozycji aby za pomocą luźnej rozmowy swobodnie wyjsśc $\mathrm{z}$ sytuacji wywiadu. Niemniej tendencja moich rozmówców do pośpiechu narzucała mi rolę socjologa-wypytywacza, nastawienie celowościowe do wywiadu, kontrolowanie czasu, ustawienie hierarchii pytań zadawania na początku najważniejszych pytań i zgadzanie się na asymetryczną relację, w której przyjmowałem rolę biorącego. Zdałem sobie sprawę, że nawet jeśli rozmówca obdarza mnie zaufaniem i jego narracja ptynie to ideał swobodnej rozmowy jest nieosiągalny, gdyż sama sytuacja wywiadu zaistniała z potrzeby jednej strony czyli badacza. To badacz ma potrzebę wyniesienia konkretnych informacji z rozmowy, a jego interlokutor zazwyczaj nie ma sprecyzowanych oczekiwań. Niemniej, pocieszeniem dla badacza może być, iż czasami zadając głębokie pytania stwarza swym rozmówcom okazję do namysłu nad własnym życiem, służącej 
lepszemu zrozumieniu siebie refleksji nad swoimi poglądami czy wyborami życiowymi, osiągając tzw. efekt terapeutyczny wywiadu (Konecki 2000: 173)

\subsection{Wywiad narracyjny}

Wywiad narracyjny jest swoistą formą zaliczanego do technik jakościowych wywiadu socjologicznego, znacznie bardziej ograniczającą udział $\mathrm{w}$ rozmowie prowadzącego badania. W przypadku tej formy wywiadu, istotą roli badacza jest sprowokowanie interlokutora do opowiedzenia historii swojego życia lub istotnych doświadczeń życiowych (Por. Konecki ibidem: 180). Wywiad narracyjny ma swoje fazy, na początku prowadzący w swobodny sposób zagaja rozmowę o niezwiązanych bezpośrednio $\mathrm{z}$ wywiadem sprawach buduje atmosferę zaufania, przekonując interlokutora, iż jest godnym daru, jakim jest powierzenie historii życia. Druga faza nosi nazwę stymulowania narracji, Przed włączeniem dyktafonu, musi wyjaśnić szczególny charakter wywiadu, uprzedzić o swoim milczeniu w trakcie wywiadu, stworzyć przestrzeń do wyjaśnienia wszystkich wątpliwości partnera rozmowy. Trzecia faza to swobodne snucie narracji i w trakcie jej prowadzący wywiad nie tylko zamienia się $w$ stuch, dążąc do niezakłócania opowieści i unikając wpływania na treść uzyskanego przekazu, lecz musi nieustannie dawać dowody, iż słucha uważnie. Na pojawiające się niekiedy pytania ze strony narratora odpowiada znakami niewerbalnymi lub możliwie neutralnymi słowami, zachęcającymi do kontynuacji narracji. Badaczowi nie wolno oceniać czy komentować historii w trakcie narracji, nie powinien okazywać emocji ani zniecierpliwienia. Badacz musi się upewnić, iż narracja została zakończona wyraźnym znakiem, tzw. kodq i dopiero wtedy zadaje uzupełniające pytania. Pytania badacza powinny być związane $\mathrm{z}$ opowieścią interlokutora, badacz powinien dążyć do rozwikłania niejasności, zamknięcia form wyjaśnienia dalszych losów pojawiających się w opowieści istotnych osób i epizodów. Można też zachęcić rozmówcę do pogłębienia pewnych wątków, poszerzenia obrazu o przeżywane emocje. Końcowa faza wywiadu to miękkie przejście do codzienności poprzez zwykłą rozmowę, w której badacz ma pełne prawo do opowiedzenia o swoich doświadczeniach, by uzyskać wrażenie równowagi (Konecki ibidem: 183).

Podstawowym założeniem wywiadu narracyjnego jest teza o homologii pomiędzy strukturq organizacji doświadczenia różnych wydarzeń $w$ realnym życiu a struktura narracji autobiograficznej (Konecki ibidem: 180). Możliwa jest analogia 
dotycząca spojrzenia ekologicznego, w którym w mikrokosmosie ujrzeć można makrokosmos, w historii pojedynczego człowieka pojawia się znaki i symbole przeżywanych epok, konkretyzacje społeczno-gospodarczych przemian o charakterze makrostrukturalnym czy ruchów społecznych, ważne wydarzenia i fakty dla grup, do jakich należy i podzielane z innymi wierzenia i przekonania. Zadaniem badacza jest wydobycie osi opowieści czyli tak zwanego głównego schematu działania.

Udało mi się przeprowadzić około 8-10 autentycznych wywiadów narracyjnych, zazwyczaj ze względu na pośpiech ze strony rozmówców lub brak zamiłowania do dzielenia się własnymi doświadczeniami, narracje często okazywały się zbyt krótkimi opowieściami aby można je potraktować jako narracje. W takich sytuacjach w sposób płynny przechodziłem do wywiadu swobodnego z ustalonym zestawem pytań, co okazywało się bardziej skuteczną formą kontaktu, ze względu na cenioną przez rolników większą konkretność.

\subsection{Jakościowa analiza treści}

Pomocniczą techniką badawczą była analiza treści, której istotą było zapoznanie się z treścią materiałów prasowych i internetowych poświęconych rolnictwu ekologicznemu i publikacji tematycznych celem dokonania krytycznej oceny ich zawartości. Szczególną uwagę poświęciłem analizie kwartalnika Eko Arka, który w obecnej chwili jest jedynym forum komunikacyjnym stworzonym przez samych eko-rolników.

Analiza treści jest uznawana za rodzaj badań niereaktywnych czyli metod badania zachowań spolecznych, nie wphywajacych na te zachowania (Babbie 2003: 341). Analiza treści to rodzaj studiowania zawartości, profilu i skuteczności kanałów komunikacji. Zdaniem Babbiego (ibidem), powinna dążyć do znalezienia odpowiedzi na pytanie: kto mówi, co, do kogo, dlaczego, jak i z jakim skutkiem? (s. 342). Wnikliwy badacz powinien zmierzać do odczytania nie tylko jawnych treści przekazu, czyli denotacji, ale również treści ukrytych czyli konotacji, skojarzeń i kodów mogących wzbudzać w grupie odbiorców.

Istnieje cały nurt badawczy ilościowej analizy treści, skupiający się na pomiarze częstotliwości występowania określonych jednostek analizy w badanym kanale komunikacji (np. czasopismo, program telewizyjny): słów, reklam, osób. W moich badaniach nie stosowałem analizy ilościowej, lecz jakościową dążąc do dotarcia do 
samej logiki przekazów, stosując właściwy teorii ugruntowanej, paradygmat kodowania. W myśl teorii ugruntowanej, zastane treści prasowe czy publikacje książkowe można kodować $w$ identyczny sposób jak informacje wynikające z przeprowadzonych przez badacza obserwacji i wywiadów.

\subsection{Obserwacja uczestnicząca}

Obserwacja jest jedną z rudymentarnych technik badań socjologicznych i jako technika badawcza przybiera formę intencjonalnego obserwowania. Wedle konstatacji Tadeusza Kotarbińskiego, obserwowanie to postrzeganie planowe. Gdy zauważyłem coś niechcacy, postrzegłem tylko; gdy wypatrywałem by zauważyć, zaobserwowatem (wg Sztumski 1995: 112). Obserwacja uczestnicząca uchodzi za formę obserwacji bezpośredniej, jej istotą jest spojrzenie od wewnątrz, przeprowadzenie obserwacji z pozycji uczestnika, dzięki wejściu badacza do badanej zbiorowości na okres badań (Por. Sztumski ibidem: 115).

Obserwacja uczestnicząca może odznaczać się różnym stopniem standaryzacji (Lutyński 2000: 130). W przypadku obserwacji uczestniczącej standaryzowanej badacz przygotowuje karty obserwacji i koncentruje swą uwagę na bardzo konkretnych aspektach obserwowanego procesu, takie karty są bardzo użyteczne przy większych projektach badawczych, wykonywanych przez cały sztab ludzi, gdyż umożliwiają zarządzającym procesem badawczym naukowcom dokładną kontrolę i skuteczną analizę zaobserwowanych danych. Podczas gdy w przypadku obserwacji o niskim stopniu obserwacji mamy do czynienia z większa rolą badacza, jego percepcji i intuicji, badacz jest bardziej otwarty na subtelne fenomeny, zmianę zagadnienia, na którym koncentruje uwagę, technika ta umożliwia pełniejsze podążanie za żywym procesem. Badacz we właściwy sobie sposób spisuje obserwacje, które potem mogą $\mathrm{mu}$ posłużyć do sporządzenia nota teoretycznej. W niewielkich badaniach o charakterze eksploracyjnym, takich jak moje własne, lepiej sprawdza się obserwacja o niskim poziomie standaryzacji, umożliwiając wierniejszą rejestrację różnych elementów świata społecznego rolników ekologicznych.

Cechami obserwacji uczestniczącej są: selektywny i wybiórczy charakter, konieczność pewnego ukierunkowania perspektywy na zachowania postrzegane przez badacza jako znaczące, tak zwana lejkowata struktura (Ślęzak 2009: 22). Analiza 
stanów emocjonalnych badacza sprzyja także innowacji, podtrzymywaniu kontekstu odkrycia badań (serendipity) (Konecki 2000: 155).

Obserwację uczestniczące można podzielić również na jawną i ukrytą (Konecki ibidem: 148). Jawna ma miejsce w sytuacji otwartej postawy badacza, który odsłania swą tożsamość wchodząc w interakcje z badanymi. Ryzykiem obserwacji jawnej jest niebezpieczeństwo nieautentycznych zachowaniach badanych odbiegających od codziennych wzorców, celem stworzenia dobrego wrażenia (Por. Sztumski 1995: 116). Obserwacja ukryta ma miejsce w sytuacji utajnienia przez badacza swego właściwego celu nawiązywania interakcji. Technika drugiego typu wiąże się z podstawowymi pytaniami etycznymi dotyczącym moralnej zgody na rodzaj oszustwa, za jaki można poczytywać mistyfikacje tożsamości badacza. Jednakże, jeśli celem badacza jest dotarcie do bardzo trudno dostępnych danych na przykład $\mathrm{w}$ badaniu ściśle określonych środowisk, np. grup przestępczych, obserwacja ukryta jest wskazaną metodą. Także obserwacja ukryta jest odpowiednim narzędziem, gdy celem badacza jest dotarcie do hermetycznych kodów danej grupy i emocjonalne doświadczenie istniejących $\mathrm{w}$ danych grupach ról. Technika ta sprawdziła się przykładowo w przeprowadzonych przez Krzysztofa Koneckiego (1992) badaniach folkloru fabrycznego, w których badacz został zatrudniony w zakładzie przemysłowym jako niewykwalifikowany sprzątacz.

W moim przypadku nie miałem powodów do stosowania obserwacji ukrytej. Po pierwsze, rola społeczna badacza cieszyła się dużą legitymizacja społeczną wśród ekorolników, część z nich wcześniej była zaznajomionych z fenomenem studenta prowadzącego badania, lecz niemal zawsze chodziło o wcześniejsze doświadczenia badania gospodarstw z punktu widzenia nauk rolniczych, w których głównym obiektem koncentracji było gospodarstwo, a nie gospodarz lub gospodyni. Zauważyłem również, iż rolnikom było przyjemnie, iż przedstawiciel świata nauki interesuje się ich działalnością, gdyż odbierali to jako swoisty wyraz uznania i legitymizacji ich praktyki jako godnej naukowych opracowań. Po drugie, czułem się dużo bardziej komfortowo ukazując się jako badacz, gdyż nie miałem wyrzutów sumienia ani lęków, które z pewnością by się pojawiły, gdybym wcielił się np. w postać młodego rolnika. Fakt, iż badana grupa społeczna cieszy się moją sympatią ułatwiał mi uczestnictwo $\mathrm{w}$ spotkaniach jej przedstawicieli, gdzie najczęściej przyjmowałem rolę życzliwego obserwatora, sporadycznie dzieląc się moją wiedzą i opiniami. W przypadku udziału w pielgrzymce rolników ekologicznych, imprezie, 
w której brało udział kilkuset osób, mogłem komfortowo prowadzić obserwacje, będąc niemal zupełnie niezauważalnym. Jednakże prowadząc rozmowy $\mathrm{w}$ czasie pielgrzymki, zawsze ujawniałem swój status studenta socjologii, zajmującego się badaniem rolnictwa ekologicznego.

Rola obserwacji uczestniczącej $\mathrm{w}$ moich badaniach była jedynie pomocnicza. Wybór ten podyktowany był wysokim stopniem rozproszenia i indywidualizacji badanej grupy. Rolnicy i rolniczki pracują na własną rękę, rzadko się spotykając. Praca rolnika jest zazwyczaj bardzo czasochłonna i jedynie sporadycznie znajdują oni czas na wspólne zebranie organizacji (najczęściej raz na kwartał, niekiedy raz na rok), z którego i tak wyjeżdżają jak najszybciej, bo czekają krowy lub by nie wracać na wieś po ciemku. Niektóre organizacje funkcjonują de facto bez regularnych zebrań, gdyż prezes i zarząd komunikują się z członkami za pomocą telefonu czy poczty. Oprócz tego raz na rok pojawiają się szczególne imprezy związane z rolnictwem ekologicznym, takie jak Pielgrzymka do Częstochowy czy Dożynki w Przysieku, gdzie spotkać można znaczną część ogólnopolskiego środowiska rolników ekologicznych. Ewentualnie jeszcze obserwacje można by prowadzić na targach lub imprezach branżowych, gdzie jednak najczęściej wymagana była akredytacja, z którą wiązała się dosyć wysoka opłata. Poza dosłownie kilkoma dniami w roku przeznaczonymi na udział w owych imprezach lub zebraniach organizacji i jednym lub dwóm dniom w tygodniu przeznaczonym na dostarczenie żywności do sklepów w mieście (poznałem przypadki kilku ekorolników, którzy w czwartki jeżdżą z towarem do Warszawy, a w piątki do Łodzi), większość ekorolników skupia się na pracy w gospodarstwie. 


\section{Kontekst historyczny i ideologiczny rozwoju rolnictwa ekologicznego w Polsce i w świecie.}

\section{Przedstawienie głównych szkót i technik rolnictwa ekologicznego}

\subsection{Rudolf Steiner i biodynamika}

W tym miejscu proponuję przyjrzenie się najstarszej, najbardziej skomplikowanej i być może najbardziej interesującej z metod upraw ekologicznych biodynamice. Metoda ta jest szczególnie ważna dla rozwoju polskiego rolnictwa ekologicznego ze względów historycznych: pierwszego kursu R. Steinera i popularności metod biodynamicznych w początkowej fazie rozwoju polskiego ekorolnictwa w latach 80 i 90 ubiegłego wieku.

W literaturze podkreśla się często, iż Polska jest krajem szczególnie ważnym w historii rolnictwa ekologicznego, gdyż tu właśnie w położonych koło Wrocławia Kobierzycach w 1924 roku dr Rudolf Steiner przeprowadził pierwszy w historii kurs rolnictwa biodynamicznego (Por. Osetek i Osetek 1989: 8). Fakt, iż Kobierzyce leżały wówczas na obszarze Niemiec, nie zmniejsza symbolicznego znaczenia tego miejsca. Przyciągało ono licznych zafascynowanych rolnictwem ekologicznym rolników z Zachodu, a niektórzy $\mathrm{z}$ nich, jak szwajcarski miłośnik biodynamiki Peter Stratenwerth zdecydowali się pozostać na stałe w Polsce. Steiner podkreślał znaczenie praktyczne doświadczenia $\mathrm{w}$ budowie rolniczych teorii: $O$ rolnictwie może się wypowiadać $w$ sposób kompetentny właściwie tylko ten, kto może oprzeć się na własnym doświadczeniu, które wynióst z pracy na roli, $w$ lesie przy zwierzętach (Biuletyn Demeter nr 5/2006:24). Rolnictwo biodynamiczne jest oparte na idei głębokiej współzależności wszystkich istot, roślin i ciał niebieskich. W holistycznej wizji Steinera (1999), stosunek gwiazd do człowieka oraz człowieka do gwiazd istnieje przecież realnie, tak realnie jak stosunek człowieka do wotu, obok którego przechodzi, a którego mięso potem zjada (s. 43). Oto jak ową zależność przedstawia Maria Hun (1998), autorka kalendarzy księżycowych i uznana propagatorka biodynamiki: Roślina posiada zdolność uwidaczniania oddziaływań płynacych od gwiazd poprzez ukształtowanie swojej formy. Również wytwarzanie przez roślinę substancji odżywczych, takich jak np. biatko, thuszcze, węglowodany $i$ sole, 
pobudzane jest rytmami kosmicznymi. Roślina odbiera również impulsy wplywające na jej wzrost (s. 9).

Metafizyczna wizja biodynamiki zakłada istnienie Matki-Ziemia (motyw greckiej Gai) i Ojca-Kosmosu (grecki Uranos), którzy razem współpracując powołują do życia świat (Osetek i Osetek 1989: 13). Podstawową kategorią biodynamiki jest kosmiczna energia, zwana niekiedy gwiezdna energią. Planety przesyłają roślinom, zwierzętom i ludziom różne rodzaje owej energii. Wedle Steinera (1999):

Można krótko powiedzieć: $w$ krzemionce działaja Saturn, Jowisz, Mars, w wapieniu zaś działaja Księżyc, Wenus, Merkury... Ale gdy rośliny staja się pożywieniem dla zwierząt $i$ ludzi, wtedy biora $w$ tym udział Mars, Jowisz, Saturn. Gdy znów wszystko, co w roślinie objawia się jako siła rośnięcia, to wszystko wpływa poprzez wapień z Księżyca, Wenus i Merkurego (s. 24).

Steiner $\mathrm{w}$ swej mowie inaugurującej rolnictwo biodynamiczne przedstawił wizję łączącą ów wymiar kosmiczny świata $\mathrm{z}$ praktycznymi wskazówkami ekologicznymi, utrzymywania zadrzewień, sprzyjania osiedlaniu się na gospodarstwach ptaków, owadów czy pojawianiu się grzybów. W wypowiedzi Steinera (ibidem): podobnie jak owady, ptaki, lasy, wspótdziałaja ze sobq, reguluja sity gwiezdne, tak znów larwy, robaki $w$ powiq̨zaniu z wapieniem $w$ glebie reguluja sity ksztaltotwórcze planetarne (s. 24).

Zrozumienie biodynamiki wymaga przyjęcia perspektywy socjologicznej otwartej na twórczą rolę Przyrody, takiej jak np. perspektywa Simmla. Obserwowane przez biodynamików interakcje mają charakter kosmiczny, człowiek wchodzi w interakcje nie tylko z rośliną, lecz i ciałami niebieskimi. Otrzymując od nich poprzez rośliny sygnały musi na nowo dostosować się do zmienionej rzeczywistości. Biodynamicy ujmują gospodarstwo rolne jako indywidualny organizm o maksymalnie zamkniętym obiegu materii ( $\mathrm{w}$ oparciu o własne nawozy $\mathrm{i}$ pasze), jest to mikrokosmos, który jest odbiciem makrokosmosu. Omawiana filozofia rolnictwa zakłada stosowanie specjalnych preparatów biodynamicznych i ziołowych do dynamizowania kompostu.

W okresie PRL-u jedynym praktykiem tego rodzaju rolnictwa był inż. Julian Osetek, właściciel 3-hektarowego gospodarstwa koło Nakła nad Notecią, stosujący owe metody od 1960 roku. Niezmiernie ciekawa jest legenda Osetka, samotnego 
praktyka, który po 20 latach zdobywa zainteresowanie środowisk naukowych. Wedle relacji Urszuli Sołtysiak (1998):

Dziennikarze, korzystając z rozluźnionej cenzury, odważyli się na krytykę rolnictwa degradującego środowisko przyrodnicze i jakość produktów rolnych, etykę zawodu i kulturę wiejska. Wtedy tė odnaleziono rodzimy przykład alternatywny: biodynamiczne gospodarstwo inz. J. Osetka, który umiejętnie wykorzystat aktywność mediów, by rozbudzić publiczne zainteresowanie hastem rolnictwo biodynamiczne. Zafascynowato ono prof. Mieczystawa Górnego, ekologa gleby, który - jak sam powiada- $w$ metodzie biodynamicznej znalazt praktyczne zastosowanie swej wiedzy teoretycznej. Dzięki niestrudzonej działalności upowszechnionej obydwu popularyzatorów, metoda biodynamiczna stała się $w$ Polsce $w$ latach osiemdziesiatych synonimem ekologicznej alternatywy $w$ rolnictwie (s. 145-146).

W latach 1980-ych na fali odwilży politycznej spowodowanej umowami sierpniowymi zaistniały warunki do organizacji kursów biodynamiki prowadzonych przez specjalistów z zagranicy i ową metodą zainteresowało się szersze grono rolników, naukowców i doradców rolnych, którzy na piątym kursie biodynamiki w lutym 1989 roku zdecydowali się na powołanie stowarzyszenie "EKOLAND".

Zależność pomiędzy rolnictwem biodynamicznym a rolnictwem ekologicznym wygląda następująco: każde gospodarstwo biodynamiczne jest jednocześnie ekologiczne, lecz nie każde gospodarstwo ekologiczne jest biodynamiczne. Istnieje międzynarodowy system biodynamicznej certyfikacji gospodarstw opracowany przez międzynarodową organizację biodynamików: Demeter International. W Polsce spółka Bioekspert, jedna $\mathrm{z}$ siedmiu jednostek certyfikujących dokonuje certyfikacji biodynamicznej (www.bioekspert.waw.pl). Produkty biodynamiczne, oznaczone marką „Demeter”, mają opinię produktów najwyższej jakości i zdobywają rosnące rzesze odbiorców na całym świecie. Biodynamika to bowiem jak to ujął jeden z ekorolników wyższe arkana sztuki, stawia większe wymagania rolnikom i może być postrzegana jako kolejny etap w ekologizacji, lepszej integracji z przyrodą.

\subsection{Rolnictwo organiczne i biologiczne}

Zdaniem znawczyni rolnictwa ekologicznego Urszuli Sołtysiak, historyczne metody, które dały początek rolnictwu ekologicznemu to metoda biodynamiczna (Steiner 1924), organiczna (Howard-Balfour 1940-46; Rodale 1942), organiczno- 
biologiczna (Landbau, Mueller-Rusch 1946-68), biologiczna (Lemaire-Boucher ok. 1960). Spajającą je ideą jest wytwarzanie żywności o najwyższych walorach biologicznych przy zachowaniu biologicznej równowagi w środowisku (Sołtysiak 1995: 11). Na obszarze języka angielskiego przyjęła się nazwa organic farming, a francuskiego agriculture biologique, w Hiszpanii podobnie do polskiego terminu rolnictwo ekologiczne: agricultura ecológica. Współcześnie przyjmuje się, że terminy te są synonimiczne i termin organic farming tłumaczy się używając zakorzenionego w Polsce terminu rolnictwo ekologiczne. Niemniej, owe różnice mają swe źródło whistorii angielskich czy francuskich pionierów, którzy tworząc bardzo podobne, alternatywne wobec technologicznego rolnictwa upraw, metody, stosowali odmienne terminy.

Stworzenie metody organiczno-biologicznej przypisuje się szwajcarskiemu działaczowi chłopskiemu Hansowi Müllerowi, którego ideą było uniezależniane gospodarki rolnej od nakładów spoza rolnictwa poprzez utrzymanie żyzności gleby przy wykorzystaniu zasobów własnych gospodarstwa. Wspomniany cel zamierzał osiągnąc poprzez stosowanie płodozmianu i nawozów organicznych, zachowywanie różnorodności gatunkowej roślin, sprzyjanie wzrostowi aktywności mikroflory, spulchnianie gleby (Lulewicz 2006: 17). Stosowanie owych naturalnych praktyk miało zapewnić uzyskiwanie plonów roślin wysokiej jakości bez używania nawozów sztucznych i chemicznych środków ochrony roślin. Metoda organiczno-biologiczna jest rozpowszechniona w Niemczech, Szwajcarii i Austrii, najbardziej znanych organizacji skupiających rolników działających według tej metody jest powstały na obszarze krajów niemieckojęzycznych w 1987 roku Związek Rolnictwa OrganicznoBiologicznego „Bioland” (Lulewicz ibidem: 17).

Pod terminem metod organicznych ukrywają się rozpowszechniona w Anglii metoda Howarda Balfour (organic agriculture), i bardziej popularną w Stanach Zjednoczonych metodę J.I. Rodale (organic farming). Obydwie metody proponują naturalny system produkcji, który wyklucza stosowanie środków chemicznych i obejmuje stosowanie płodozmianów, resztek pożniwnych, obornika, roślin motylkowych, nawozów zielonych, zmielonych skał zawierających mineralne składniki odżywcze, zapewnienie roślinom wystarczającej ilości składników odżywczych i ochrony przed chorobami i chwastami (Lulewicz ibidem: 17).

We Francji wykształciło się tzw. rolnictwo biologiczne, a jego rozwój związany jest z nazwiskami prof. R. Lemaire'a i J. Boucher'a i ruchem społecznym Nature et 
Progres. Novum metody Lemaire'a było podnoszenie żyzności gleby przez zastosowanie kompostów z dodatkiem glonów morskich, których popularność doprowadziła do powstania w 1963 roku przedsiębiorstwa S.V.B Lemaire, zajmującego się produkcją Calmagolu (nazwa handlowa nawozu $\mathrm{z}$ glonu Lithotamnium) oraz innych środków i narzędzi rolniczych.

Wspólna ideą tych wszystkich metod było porzucenie wytwarzanych w chemicznych fabrykach środków ochrony roślinnych, nawozów, polepszaczy, regulatorów wzrostu roślin i powrót do tradycyjnych praktyk, takich jak płodozmian lub tworzenie innowacyjnych preparatów w oparciu o naturalne substancje organiczne. Wszystkie owe nurty przyczynily się do rozwoju ruchów społecznych na rzecz rolnictwa ekologicznego, które w 1972 r. utworzyły międzynarodową organizację IFOAM, jednocześnie uznając pluralizm szkół rolnictwa ekologicznego za cenną wartość i uruchamiając proces poszukiwania wspólnego gruntu w postaci międzynarodowych kryteriów eko-rolnictwa.

1.3 Polscy prekursorzy rolnictwa ekologicznego

Zdaniem wybitnego propagatora rolnictwa ekologicznego Mieczysława Górnego (2005c), na miano europejskiego pioniera rolnictwa ekologicznego zasługuje hrabia Dezydery Chłapowski, który w XIX wieku wspaniale gospodarowat na majątku w Turwi. Na swym gospodarstwie Chłapowski podjął się dzieła zadrzewienia, dostrzegając symbiotyczne działanie drzew wobec upraw i hodowli: chronienie przed wiatrem, poprawę mikroklimatu, zmniejszenie parowania i erozji gleb, ochrony upraw przed szkodnikami. Ów hrabia zwykł sadzić drzewa rodzimych gatunków w prostokątnych pasach. Tak oto profesor Górny (ibidem) relacjonuje rewolucyjność jego odkryć: by ograniczyć szkodniki, gryzonie, wystarczy $w$ pasy zadrzewień wsadzić co pewien czas sosny iświerki, na których będq siadały drapieżniki, jastrzębie, myszołowy, itp (s. 33). Zbigniew Przybylak (2005a), redaktor naczelny promującego rolnictwo ekologiczne kwartalnika Eko Arka za prekursora ekorolnictwa również uznaje gen Chłapowskiego Propagator rolnictwa biodynamicznego Roman Świątek z podziwem wspomina Chłapowskiego jako postępowego, proekologicznego rolnika, wielkiego Wielkopolanina, który jako 27-letni żolnierz porzucit rzemiosto wojenne, stając się rolnikiem, nie tylko pisat podręczniki o uprawie ziemi, lecz sam zajmował się kształceniem przysztych rolników (Biuletyn 
Demeter nr 5/2006: 22). Niniejszym w legendzie Chłapowskiego pojawia się jeszcze wątek pacyfistyczny: porzucenia wojska na rzecz uprawy roli jako właściwszej drogi walki o zmianę społeczeństwa. Chłapowski służy również za wzór filantropa i społecznika. Oto jak opisuje jego dokonania Świątek w omawianym artykule:

Chłapowski nie zabiegając o poklask budowat bardzo oszczędne zabudowania folwarczne stając się pierwowzorem organicznej pracy od podstaw, jak by to dzisiaj powiedzieć wg zasad zrównoważonego rozwoju. Do tego zdumiewającym było, że $w$ majątku w Turwi i na folwarkach zamieszkiwato do stu osób. Byli to - jak napisal Morawski "obok domowników emigranci, sieroty, chorzy i nieszkodliwi wariaci, którym miłosierdzie kazało zapewnić dach nad głowa" (Biuletyn Demeter ibidem, s.22).

W okresie międzywojennym wytrwałym propagatorem rolnictwa ekologicznego w Polsce był hrabia i senator Stanisław Karłowski (1879-1939), który wprowadził metodę biodynamiczną w swym liczącym aż 1760 hektarów majątku w Szelejewie koło Gostynina (Osetek i Osetek 1989: 9). Ów senator i zarazem ofiara nazizmu, stał się patronem Polsko-Niemieckiej Fundacji im. Stanisława Karłowskiego, która wydzierżawiła 1870 ha ziemi wgminie Borne Sulimowo w województwie zachodniopomorskim celem rozwoju rolnictwa biodynamicznego i stworzenia przestrzenie dla projektów edukacyjnych, socjoterapeutycznych i przedsięwzięć ekonomicznych (Biuletyn Demeter $\mathrm{nr}$ 5/2006: 10-11). Ogromne gospodarstwo położone jest na terenie byłego PGR na wyjałowionych, przez lata nieuprawianych ziemiach. Ogromne polsko-niemieckie gospodarstwo biodynamiczne, nastawione na produkcje wysokogatunkowej żywności, na terenie którego powstało dwujęzyczne przedszkole i wytwórnia mieszanek ziołowych, wzbudziło zainteresowanie dziennikarzy National Geographic. Oto fragment reportażu z nowoczesnego gospodarstwa biodynamicznego, w którym dziennikarka zwraca uwagę na różnorodność upraw i sposób traktowania zwierząt:

Stado 150 mlecznych krów hodowane jest $w$ luksusowych warunkach. Nowo wybudowana oborę pracownicy nazywaja pensjonatem. Rzeczywiście - to słowo znacznie lepiej pasuje do widnego, czystego $i$ przestronnego budynku, wyposażonego $w$ mechanicznie uruchamiane szczotki do masażu zwierząt. Krowy dtugowiecznej rasy czarno-biatej nie sa poddawane sztucznemu zapłodnieniu, dojone sa $w$ sposób mało eksploatacyjny, dożywaja też naturalnej śmierci (Stopa 2009). 
Jak widać, użycie nowoczesnej techniki (szczotki do masażu zwierząt) daje się pogodzić $\mathrm{z}$ troską i niezwykłym szacunkiem dla zwierząt i równoczesnym korzystaniem z tradycyjnych technik, jak kalendarz księżycowy.

\section{IFOAM i konsolidacja międzynarodowego ruchu rolnictwa ekologicznego.}

W 1972 r. miało miejsce zawiązanie w Wersalu najważniejszej międzynarodowej organizacji rolników ekologicznych IFOAM - International Federation of Organic Agriculture Movements. W 1982 roku opublikowano dokument Basic standards of organic agriculture, stanowiący pierwszą $\mathrm{w}$ historii próbę międzynarodowej kodyfikacji produkcji ekologicznej. Postanowiono również, iż owa lista standardów będzie aktualizowana odtąd co 2 lata. Kryteria te obejmują zarówno zasady produkcji, przetwórstwa, przechowywania, pakowania i znakowania eko-żywności, a także obrotu, w swej przenikliwości uwzględniają cały łańcuch: od producenta do konsumenta. Zdaniem Urszuli Sołtysiak (1995), o wartości Podstaw Kryteriów IFOAM najlepiej świadczy fakt, że stały się one punktem wyjścia dla międzynarodowego ustawodawstwa $w$ zakresie rolnictwa ekologicznego (s. 13). Za rdzeń ekologicznego sposobu gospodarowania uznano powszechnie odrzucenie środków chemii rolnej, a w przetwórstwie - spożywczej.

Obecnie IFOAM organizuje liczne międzynarodowe targi i konferencje na całym świecie, dysponuje kilkoma biurami kontynentalnym i światową siedzibą w niemieckim mieście Bonn. Owa organizacja skupia aż 750 organizacji ze 108 krajów reprezentujących szeroki wachlarz aktorów społecznego świata, poczynając od organizacji rolniczych aż po międzynarodowe agencje certyfikacyjne (www.ifoam.org, dane na 30.9.2009). Zwraca uwagę międzysektorowy charakter organizacji, która wśród swych polskich członków wymienia będące częścią sektora prywatnego trzy jednostki certyfikujące, przedstawicieli sektora obywatelskiego - dwa stowarzyszenia (Ekoland i Stowarzyszenie Ekologiczno-Kulturalne Ziarno z Grzybowa) oraz jednostkę naukową - Katedrę Rolnictwa Ekologicznego warszawskiej SGGW. Jako swoją misję federacja formułuje zapewnienie wiarygodności i żywotności rolnictwa ekologicznego jako środek tworzenia ekologicznej, gospodarczej i spolecznej 
równowagi (sustainablity1). Jako swoje główne wartości organizacja wymienia zdrowie, ekologię, sprawiedliwość i troskę (IFOAM Annual Report 2008), a za cele organizacja stawia sobie:

- budowę globalnej platformy porozumienia ruchu rolnictwa ekologicznego

- rozwój, promocję i obronę zasad rolnictwa ekologicznego

- propagowanie i ułatwianie adaptacji rolnictwa ekologicznego, zwłaszcza $\mathrm{w}$ krajach rozwijających się

- rozwój rynków żywności ekologicznej

- zapewnienie efektywnie zarządzanej organizacji wyposażonej w wystarczającą ilość zrównoważonych zasobów

\section{Rozwój rolnictwa ekologicznego w Polsce - wstapienie do Unii}

\section{Europejskiej jako punkt zwrotny}

Wstąpienie do Unii Europejskiej można rozpatrywać jako czynnik dynamizujący powstawanie gospodarstw ekologicznych w Polsce. Można nawet pokusić się o tezę, że w momencie wstąpienia Polski do Unii przekroczona została pewna masa krytyczna gospodarstw i jest to tak zwany punkt zwrotny $\mathrm{w}$ historii polskiego eko-rolnictwa. Niemniej, czynnikiem, który spowodował przyspieszenie przestawiania się gospodarstw na metody ekologiczne była dostępność unijnych funduszy pomocowych. Według danych Najwyższej Izby Kontroli, w latach 20032005 nastąpił ponad 3-krotny wzrost liczby gospodarstw ekologicznych (z 2286 do 7813) i ponad 4-krotny wzrost powierzchni upraw ekologicznych (z 39,9 tys. do 167,7 tys. ha). Najnowszy raport Inspekcji Jakości Handlu Artykułami Rolno-Spożywczymi (2009) dostarcza najnowszych danych na temat ilości i struktury regionalnej gospodarstw ekologicznych w Polsce, złożonych na podstawie danych dostarczonych przez wszystkie firmy certyfikujące. Odnotowano tam 2,5-krotny wzrost liczby ekogospodarstw w latach 2004-2006, poczynając od 3760 w 2004 roku do liczby 9194 w roku 2006 by osiągnąć stan 15206 na dzień 31 grudnia 2008 r.

\footnotetext{
${ }^{1}$ Można by z pewnością przetłumaczyć angielski termin sustainability, jako zadomowiony w polskiej mowie zrównoważony rozwój. Niemniej, termin ten ma nieco inny odcień związany z porzuceniem wieloznacznego terminu rozwój, tym bardziej podkreślając aspekt równowagi, która w sytuacji uznania limitów biosfery, przypadku wysokorozwiniętych gospodarek może wymusić ograniczenie rozwoju mierzonego wzrostem PKB.
} 
Postęp ten wydaje się niebywały, zważywszy, iż w roku 1990 mieliśmy w Polsce jedynie 27 eko-gospodarstw, w 1993174 roku, a w roku 1997 - 207 (Soltysiak 1998: 148). W dekadzie lat 90. posiadanie certyfikowanego eko-gospodarstwa było związane z członkostwem w Stowarzyszeniu Ekoland. Niespełna dziesięć lat temu czołowy polski propagator rolnictwa ekologicznego, prof. Mieczysław Górny (1997) pisał: Polscy rolnicy ekologiczni nie tylko nie otrzymuja żadnej pomocy, nie moga także uzyskać korzystnych kredytów bankowych, ani $w$ czasie przestawiania gospodarstwa, ani po tym okresie (s. 5). Brak zachęt instytucjonalnych spowodował, iż w latach 1994-97 mieliśmy do czynienia ze stagnacją, a nawet regresem: z 225 ekogospodarstw w roku 1994 liczba ich wzrosła do 235 w kolejnym roku by spaść do 207 w roku 1997. Obecnie istnieje system wsparcia instytucjonalnego dla gospodarstw ekologicznych wpisujący się $\mathrm{w}$ szerszą unijną tendencje polityczną ekologizacji rolnictwa. Liczba ponad 9 tys. eko-gospodarstw na koniec 2006 roku mogła by usprawiedliwiać postawy skrajnego optymizmu, lecz jakościowa analiza fenomenu rozwoju rolnictwa ekologicznego może być źródłem również krytycznych wniosków.

Pomimo olbrzymiego postępu w ekologizacji polskich gospodarstw rolnych, raport NIK wydaje sceptyczną diagnozę, rolnictwo ekologiczne, pomimo istniejących dobrych warunków przyrodniczych i potrzeb społecznych oraz zwiększonych nakladów finansowych wlatach 2003 - 2005 nadal nie jest odpowiednio rozwinięte (NIK 2006). Niedorozwój polskiego ekorolnictwa w porównaniu z innymi krajami UE, jest znaczący: w Polsce liczba eko-gospodarstw nie przekracza bowiem 0,5\% ogólnej liczby gospodarstw, podczas gdy średnia unijna wynosi 9\% (NIK ibidem). Wedle danych IFOAM z 2005 roku w Europie stwierdzono 190 tys. ekogospodarstw o łącznej powierzchni 6,9 milionów hektarów (Metera i Sakowski 2008: 18). W Europie odnotowuje się stały przyrost powierzchni upraw i rozwój rynku ekoproduktów (ok. 0,5 mln hektarów w ciągu lat 2004-2007), średni europejski wzrost sprzedaży eko-produktów kształtuje się na poziomie 7,8\% rocznie. Polska mając 168 tys. hektarów upraw ekologicznych jest daleka od europejskiej czołówki: zarówno Austria, jak i Czechy mają znacznie większą powierzchnię upraw: adekwatnie 361 tys. ha oraz 255 tys. ha (Metera i Sakowski ibidem: 11-13). Jak zatem widać dystans rozwoju eko-rolnictwa dzielący Polskę od średniej UE jest znaczący. 


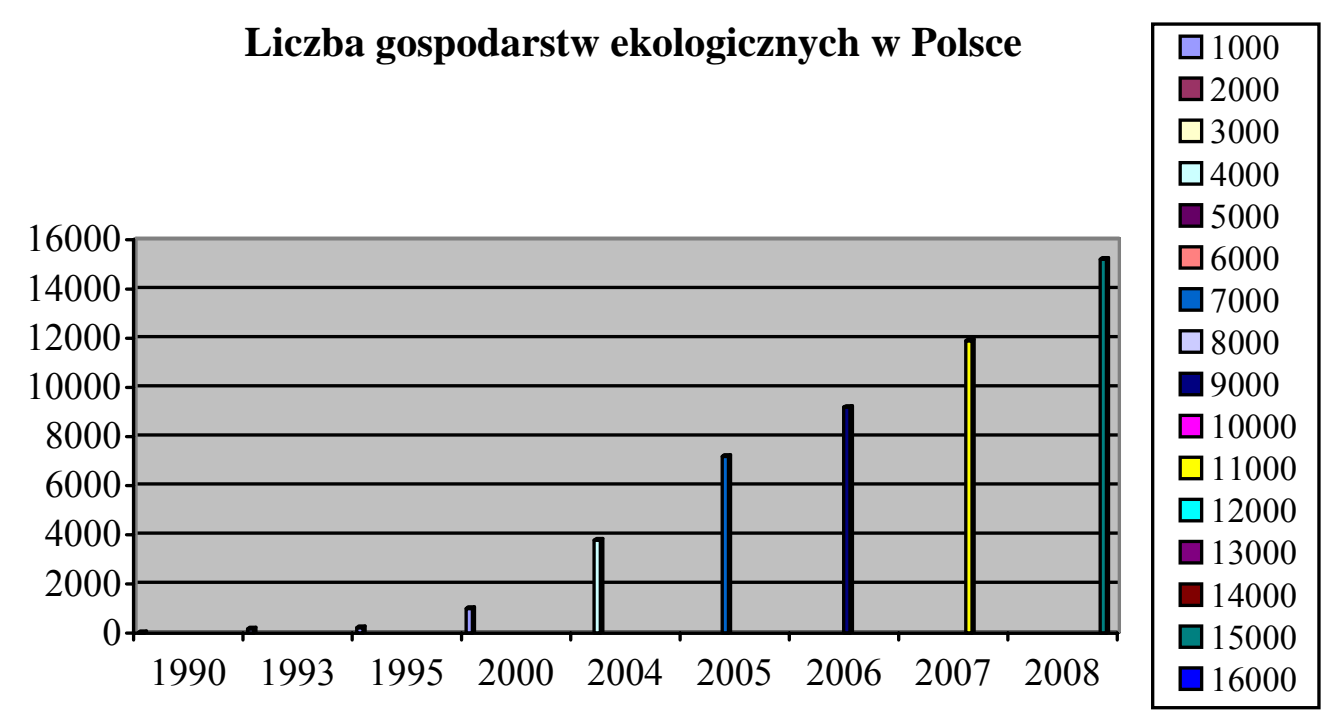

Wykres 1. Liczba gospodarstw ekologicznych w Polsce. Źródło: opracowanie własne w oparciu o dane IJHAR-S (2008 i 2009) i Sołtysiak (1998).

Zauważalne są również dysproporcje regionalne $\mathrm{w}$ ekologizacji upraw w Polsce. Tereny dawnej Galicji, mające opinie najbardziej rolniczych i konserwatywnych okazują się niekwestionowanymi liderami rolnictwa ekologicznego. Uwzględniając wszystkie gospodarstwa, tzn. certyfikowane i w trakcie przestawiania, posługując się stanem na 31.12.2008, województwo małopolskie cieszy się pozycją lidera z liczbą 2124 gospodarstw, podczas gdy podkarpackie ma ich 1927. O tym ostatnim rolnicy mówią, odwołując się do takich projektów, jak dolina Strugu, iż tam całe wsie przeszly na ekologię, tak się rozpędzili. Trzecie miejsce zajęło woj. lubelskie z liczbą 1609 gospodarstw, czwarte mazowieckie - 1547, piąte zachodniopomorskie -1412. Województwo kujawsko-pomorskie, które mogłoby aspirować do miana kolebki polskiego rolnictwa ekologicznego ze względu na ilość inicjatyw z nim związanych (siedziba główna Ekolandu i dożynki w Przysieku, redakcja Eko Arki, słynne zakłady przetwórstwa ekologicznego w Gołubiu Dobrzyniu i Pokrzydowie, gospodarstwo Osetków w Nakle nad Notecią), ma jedynie 272 gospodarstw. Najgorzej wypada w omawianej klasyfikacji województwo śląskie 192 i opolskie 62. Jeżeli uwzględnimy liczbę przetwórni, również zauważymy znaczące dysproporcje (IJHAR-S stan na 31.12.2008). Tutaj na pierwsze pozycje wysuwają się dwa najzamożniejsze województwa: mazowieckie 37 i na drugiej pozycji wielkopolskie 33, trzecie miejsce zajmuje lubelskie z liczbą 30. Zamożne województwo śląskie mając 
192 eko-rolników, dysponuje 13 przetwórniami (stosunek 1:14), podczas gdy zachodniopomorskie przy 1412 eko-gospodarstwach ma 12 przetwórni (1:117), a warmińsko-mazurskie przy liczbie 1069 producentów ma ich 9 (1: 118). Przodujące pod względem liczby eko-rolników województwo małopolskie wypada najsłabiej pod względem rozwoju infrastrukturalnym, gdyż na każdą z jego 17 przetwórni przypada 124 gospodarstw, podczas gdy w podkarpackim stosunek wynosi 1:108 (wg danych IJHAR-S na 31.12.2008). Jakkolwiek, słabością analizowanego raportu jest nieuwzględnienie wielkości i możliwości przetwórni, a jedynie ich ilość, mimo to hipoteza o niedorozwoju ekologicznej przetwórczości w skali całej Polski i regionalnych dysproporcjach zdaje się być prawdopodobna. Przetwórczość ekologiczna w Polsce jest jeszcze słabiej rozwinięta niż rolnictwo ekologiczne, a jej rozwojowi nie sprzyjają rygorystyczne wymogi weterynaryjno-sanitarne, identyczne jak dla dużych przetwórni. Trzeba pamiętać, że to w drobnej przetwórczości leży klucz do ekonomicznego sukcesu eko-rolników, którym trudno będzie dorobić się na samych surowcach pierwotnych - zbożu czy mleku. Z braku przetwórni ekologicznych wielu eko-rolników sprzedaje swoje mleko czy płody rolne do konwencjonalnych mleczarni, bądź zakładów przetwórczych, marnując kartę atutową wyższej jakości swych produktów.

W omawianym zestawieniu nie uwzględniono niecertyfikowanych przetwórni tradycyjnych i paraekologicznych. W województwie łódzkim przetwórnia założona przez jednego z pionierów rodzimego eko-rolnictwa oferuje sery białe, wędzone i topione oraz masła produkowane tradycyjnymi i ekologicznymi metodami. Firma kupuje wyłącznie mleko pochodzące z rolnictwa ekologicznego, lecz jej właściciel zrezygnował z ubiegania się o certyfikację ze względu na rygorystyczne przepisy sanitarne kolidujące z tradycyjnym stylem produkcji. Niemniej, jego produkty mają charakter praktycznie ekologiczny i cieszą się dużą renomą wśród konsumentów żywności ekologicznej. Warto by było zbadać, jak wiele jest w Polsce podobnych przypadków przetwórni de facto ekologicznych, lecz niecertyfikowanych.

Ponadto, gwałtowny trend rozwoju rolnictwa ekologicznego uległ wyraźnemu spowolnieniu w roku 2006. Według danych IJHAR-S średnia wzrostu liczby ekogospodarstw w Polsce w skali roku zmniejszyła się z 91\% do 28\% czyli uległa ponad 3krotnemu spowolnieniu i nie utrzymała się w żadnym z województw. Niemniej, pozytywnym czynnikiem jest fakt, iż we wszystkich województwach utrzymuje się tendencja wzrostowa na przyzwoitym średnim poziomie $28 \%$, w żadnym 
z województw nie osiągając wartości niższej niż $14 \%$. Analizowany raport dostarcza również danych o rozwoju ekologicznych przetwórni spożywczych. W roku 2005 było ich 90, a rok później już 163 czyli blisko dwukrotny wzrost.

Pozytywnym trendem jest rozwój sklepów z żywnością ekologiczną. Obecnie oprócz wielu sklepów ze zdrowa żywnościa istnieją certyfikowane eko-sklepy, w których sprzedawane są wylącznie produkty z certyfikatami. Jednym z takich sklepów jest rzeszowska BioAvena, która oprócz 800 certyfikowanych produktów, oferuje we współpracy z Podkarpacką Izbą Rolnictwa Ekologicznego dostawy żywności bezpośrednio do domów klientów i organizuje comiesięczne spotkania klientów z rolnikami (www.bioavena.pl). Ponadto drzwi dla eko-żywności otworzyły sklepy wielkopowierzchniowe, które przyjmują hurtowe zamówienia. Pozytywnym następstwem jest integracja eko-rolników, którzy tworzą zrzeszenia i przedstawiają oferty handlowe, mając świadomość, iż hipermarket nie będzie negocjował z pojedynczym rolnikiem. Hipermarkety choć są kojarzone ze sprzedażą taniej żywności złej jakości, mają obecnie swój udział w tworzeniu krajowego rynku żywności ekologicznej. Z punktu widzenia krajowych konsumentów i sympatyków rolnictwa ekologicznego, lepiej by polska eko-żywność wędrowała do hipermarketów niż była wywożona zagranicę. Rynek żywności ekologicznej jest najsłabiej rozwinięty w małych i średnich miastach. Warszawa może odpowiadać za sprzedać blisko połowy polskiej żywności ekologiczne, przetwórcy z odległych regionów Polski kierują często tam ponad połowę swej produkcji. 


\section{Rolnictwo ekologiczne jako zawód i powołanie}

\section{1. Świat spoleczny rolnictwa ekologicznego - aktorzy, areny sporów.}

1.1 Wprowadzenie teoretyczne

Koncepcja społecznych światów (social worlds) została po raz pierwszy zaproponowana przez T. Shibutaniego. Wedle definicji Straussa, pojęcie społecznego świata obejmuje grupy realizujące określone rodzaje działalności, dzielace się zasobami wielu rodzajów by osiągnąć swoje cele, i budujące wspólne ideologie odnoszące się do ich działalności (Strauss 1993: 212; Konecki 1998: 19; Konecki 2005: 80). Konecki (2005) podkreśla dynamiczny charakter światów społecznych, nie są one społecznymi strukturami, lecz wyodrębniona forma działania zbiorowego (s. 80). Autorzy tej koncepcji związani z symbolicznym interakcjonizmem, kładli nacisk na fakt, iż istotą społecznego świata są działania komunikacyjne, nieustanne porozumiewanie się (Kacperczyk 2005: 167-168). Konecki (1998) zauważa również, że granice społecznych światów nie są określone tak wyraźnie, jak w przypadku grup społecznych, klas, grup zawodowych (s. 19). Ze względu na ową relatywną płynność granic społecznego świata, procesy legitymizacji, czyli uprawomocniania tożsamości - przynależności do danego społecznego świata zwracają szczególną uwagę badaczy. Uczestniczące w świecie społecznym jednostki posługują się wspólną perspektywą poznawczą, porządkującą sposób widzenia świata i dostarczającą uznawanych za oczywiste cech różnych obiektów, zdarzeń czy natury ludzkiej, pomocnych w definiowaniu sytuacji (Konecki 2005: 81).

Wytyczanie granic toczy się w wyniku procesów negocjacji i walki pomiędzy różnymi opcjami, stronami, stąd pojęcie aren sporu ogniskujących się wokół sprecyzowanych problemów lub tzw. obiektów granicznych - boundary objects jest jednym z charakterystyk społecznych światów (Kacperczyk 2005: 176). W ujęciu Koneckiego (2005), każdy społeczny świat to pewny obszar kulturowy, który nie jest ustanowiony ani przez terytorium, ani przez formalne grupowe uczestnictwo, ale przez granice efektywnej komunikacji (s. 80). Na właściwych społecznemu światu arenach ścierają się określone ideologie, wizje, plany działania, koncentrujące się wokół kwestii spornych (Konecki ibidem: 82). Istnienie aren można zauważyć na 
poziomie makro, np. upublicznionych debat prasowych czy internetowych, jak i na poziomie mikro na spotkaniach przedstawicieli danego świata społecznego, wreszcie w dyskursie i autoprezentacji jednostki można czasem wychwycić istnienie areny wewnętrznej - jej rozchwiania pomiędzy różnymi stanowiskami. Podmioty społecznego świata mogą na arenie prowadzić walkę o autentyczność - wykazanie, iż ich perspektywa, cele i działania $\mathrm{w}$ większym stopniu upoważniają ich do reprezentowania społecznego świata (Konecki ibidem: 87), która to walka jest widoczna w terminie prawdziwego rolnictwa, którym często posługują się zwolennicy eko-rolnictwa. Konfrontacje pomiędzy ideologiami i podmiotami mogą prowadzić do procesów rozpadu lub tzw. pączkowania światów społecznych, w ramach których wyłaniają się tak zwane subświaty koncentrujące się wokół nowych centralnych problemów i idei.

Możemy przyjąć, iż rolnictwo ekologiczne stanowi swego rodzaju świat społeczny, obejmujący tysiące aktorów, własne kanały komunikacyjne i występowanie dyskursu, zachodzenie procesów legitymizacyjnych, istnienie różnych aren sporów. Wśród aktorów rolnictwa ekologicznego wyróżnić możemy wszystkie osoby i instytucje zainteresowane rozwojem tego rodzaju rolnictwa i wpływające na ksztalt, jaki rolnictwo ekologiczne przybiera w Polsce, między innymi agencje certyfikacyjne. Świat społeczny rolników ekologicznych nakłada się na inne światy społeczne, z którymi posiada wspólne terytoria, np. ze światem społecznym nauki, światem społecznym polityki, światem społecznym biznesu. Można rozpatrywać eko-rolnictwo w płaszczyźnie politycznej, tak na szczeblu Unii Europejskiej, jak i na szczeblu państwowym, gdzie toczy się polityczna gra o kształt polskiego rolnictwa i programów rozwoju wsi, w której uczestniczą partie polityczne, agendy i fundusze rządowe, związki rolnicze, lobby agrochemiczne, stowarzyszenia konsumenckie, itd. Funkcjonowanie rolnictwa ekologicznego w Polsce jest uregulowane prawnie specjalną ustawą z dnia 20 kwietnia 2004 o rolnictwie ekologicznym, jak i również podlega licznym unijnym regulacjom. Można zatem analizować rolnictwo ekologiczne jako fenomen regulowany prawnie - instytucje państwowe dokonały ingerencji w procesy legitymityzacyjne owego świata społecznego. Często różne światy społeczne współpracują w działaniach legimityzacyjnych, jak np. w tworzeniu opowieści zespalających konwencje nowego świata społecznego z już istniejącymi, budowanie powiązań kooperacyjnych, przejmowanie istniejącej infrastruktury (Konecki 2005: 
81). Oto najważniejsze z pokrewnych światowi społecznemu rolników ekologicznych światy społeczne:

- świat społeczny ochrony przyrody - wspieranie wysiłków na rzecz ochrony terenów cennych przyrodniczo i ochrony rzadkich gatunków, ochrona krajobrazu, obejmuje ruch ekologiczny, bliski eko-rolnictwu w zakresie walki o zdrową żywność, prawa zwierząt czy zakaz stosowania upraw genetycznie modyfikowanych, poparcie dla zamkniętych obiegów materii, idea samowystarczalności żywieniowej

- Świat społeczny tradycyjnych produktów lokalnych - ruch slow food międzynarodowy ruch na rzecz wolnego jedzenia, podobnie jak ekorolnicy promujący żywność wysokiej jakości, dążący do ratowania dziedzictwa kulinarnego jako części dziedzictwa kulturowego kraju, obecnie obejmuje nie tylko ruch społeczny, ale również np. Urzędy Marszałkowskie zaangażowane $\mathrm{w}$ proces certyfikacji produktów tradycyjnych. Ten świat społeczny rozwija się niezależnie od rolnictwa ekologicznego, lecz istnieje między nimi znacząca wspólnota aksjologiczna i podobieństwa w zakresie doświadczeń (np. zainaugurowany przez UE proces instytucjonalizacji).

- świat społeczny nauki - liczne przykłady współpracy z naukowcamidysydentami (założenie Ekolandu i Konwentu Ekologicznego) i krytyka głównego nurtu nauki. Szacunek dla naukowego poznania.

- świat społeczny biznesu - rolnicy ekologiczni jako przedsiębiorcy, zatrudniający ludzi, prowadzący działalność gospodarczą, wspólne wyzwania i interesy, coraz wyraźniej widoczny udział ekspertów od marketingu w rozwoju rolnictwa ekologicznego, promocja idei klastra, rozwój eko-marketingu, organizacja imprez branżowych, jak Organic Marketing Forum w Warszawie

- świat społeczny rolnictwa konwencjonalnego- wspólnota kulturowa obejmująca etos chłopski, symbolikę i rytuały (pielgrzymki, dożynki). Konflikt wokół filozofii rolnictwa i stosowania środków chemicznych. Tak jak protestanci i katolicy są przez przedstawicieli innych religii postrzegani łącznie jako chrześcijanie, tak dla większości nierolniczego ogółu społeczeństwa rolnicy ekologiczny i konwencjonalny to przede 
wszystkim rolnicy jako jedna grupa zawodowa - tendencja widoczna w różnych statystykach.

- świat społeczny polityki i administracji państwowej - uprawnienia władzy do regulowania norm wpływających na trajektorie życia ekorolników, próby organów władzy wyznaczania granic społecznego świata, ukłony polityków w stronę rolnictwa ekologicznego (moda na ekologiczności, rosnący eko-elektorat)

- świat społeczny konsumentów - konsumenci to najważniejsi partnerzy działalności rolników, od nich zależy powodzenie ich przedsięwzięć gospodarczych, wspólne postulaty z ruchem obrony praw konsumentów - np. prawo do informacji

- świat społeczny alterglobalizmu - podzielane idee dezaprobaty wobec wielkich koncernów międzynarodowych, zwłaszcza agrochemicznych i potrzeby budowy nowego bardziej sprawiedliwego społeczeństwa

1.2 Najważniejsza arena sporu: ekologia przeciw konwencji

Podstawową areną sporu jest spór rolnictwa ekologicznego z rolnictwem technologicznym lub przemysłowym, zwanym powszechnie konwencjonalnym, w mowie potocznej eko-rolnicy określają siebie jako ekologię, a przeciwników jako konwencję. Rolnicy ekologiczni, jak każda grupa społeczna, budują swoją tożsamość w poczuciu odrębności od innych, w tym wypadku chodzi o ich odmienność od znacznie szerszej i potężniejszej grupy tzw. rolników konwencjonalnych. Na Zachodzie geneza rolnictwa ekologicznego związana jest z kontrkulturą i ucieczką z miasta na wieś kontestacyjnie zorientowanych i zarazem przedsiębiorczych młodych ludzi. W Polsce aspekt ten zdaje się być mało widoczny. Niemniej, ekorolnicy stanowią w Polsce odrębne środowisko: mają własne stowarzyszenie i od niedawna własny związek zawodowy. Organizują wspólne festyny, a nawet własne pielgrzymki do Częstochowy.

Rolnicy konwencjonalni często nie są świadomi tego sporu, reprezentują tendencje unifikującą, sami rzadko posługują się etykietą przemystowości czy konwencjonalności. Podstawową osią niezgody pomiędzy obydwoma światami społecznymi jest przyzwolenie rolnictwa konwencjonalnego na stosowanie całej gamy syntetycznych środków chemicznych (głównie nawozów i tzw. środków ochrony 
roślin) celem zwiększenia wydajności upraw. Podstawowym założeniem rolnictwa ekologicznego jest zaś odrzucenie chemii, postawienie na biologię czyli współpraca z przyrodą poprzez wspieranie naturalnych procesów.

Fragment książki propagatora rolnictwa ekologicznego Mieczysława Górnego (2002) pozwala dostrzec ważny wymiar owego konfliktu:

\begin{abstract}
Zwolennicy intensywnego, przemystowego rolnictwa pytają: Czy można zrezygnować z dążeń do podwyższenia plonów, skoro wiele ludzi na świecie głoduje, a przy tym ludzi wciąz przybywa? Czy można zrezygnować ze stosowania pestycydów gdy trzeba chronić uprawy przed szkodnikami, chorobami i chwastami? Czy można ograniczyć stosowanie lub $w$ ogóle nie stosować leków weterynaryjnych, skoro wymaga tego intensywny, skomasowany chów zwierząt gospodarskich? (...) Na szczesście sq dziś jeszcze i w Polsce, i na świecie dobrzy rolnicy, którzy stawiaja inaczej pytania (...): Jak prowadzić gospodarstwo rolne $w$ sposób trwale efektywny? Jak gospodarować, aby zapewnić harmonię między czlowiekiem a przyrodą? (...) Jak osiagnać wysokq jakość żywieniowa plodów rolnych? Ponieważ rolnicy tak stawiajacy pytania, madrzy i myślacy kategoriami ekorozwoju, wcią̇ wskutek niewłaściwego systemu edukacji, stanowia mniejszość, dlatego rolnictwo ekologiczne uznano za alternatywne, a wspólczesne, technologiczne $w$ swej koncepcji, rolnictwo za konwencjonalne (s. 7, podkr. PB).
\end{abstract}

W percepcji owego wybitnego ideologa rolnictwa ekologicznego, etykieta konwencji wynikała z większej liczebności i związanej z nią większej siły społecznopolitycznej rolnictwa przemysłowego. W istocie toczy się walka o tytuł konwencjonalności, czyli prawa do wyznaczania konwencji, jeśli rolnikom ekologicznym uda się kiedyś wyprzedzić swą liczebnością rolników technologicznych to ich rolnictwo zostanie uznane za dominujący społecznie legitymizowany model. Jakkolwiek osiągnięcie tego celu wydaje się całkiem nierealne przynajmniej w horyzoncie najbliższej dekady, interesuje mnie fakt mającej miejsce tu i teraz walki o hegemonię. Jako, że kategoria konwencjonalności świadczy o posiadaniu hegemonii, zwolennicy ekologicznego rolnictwa świadomie pozbawiają jej przeciwnika, tak jak Górny (ibidem), który wolał określić adwersarzy etykietą rolnictwa przemystowego (s. 55-66). Na przykładzie tego fragmentu tekstu można zauważyć, iż arena sporu ma wymiar nie tylko techniczny, lecz również świadomościowy i moralny, o czym świadczą kategorie dobra i mądrości przypisane rolnikom ekologicznym. 
Znany ideolog rolnictwa ekologicznego Zbigniew Przybylak w ramach omawianej areny posługuje się taktyką negacji prawdziwości rolnictwa konwencjonalnego, odmawiając konwencji statutu rolnictwa, sprowadza je jedynie do przemystowej uprawy ziemi, co należy odebrać jako formę degradacji. Przybylak (2003) pisze:

Otóż dziwnym zrzqdzeniem losu, jesteśmy, $w$ zasadzie, jedynym krajem $w$ Europie i $w$ krajach wysoko rozwiniętych, który posiada jeszcze prawdziwe rolnictwo. Piszę to $z$ petnq świadomościa, bowiem tak naprawdę, $w$ kręgu cywilizacji technicznej, $w$ Europie i Ameryce Pótnocnej, trzeba mówić raczej o przemystowej i bardzo energochtonnej uprawie ziemi (s. 237).

W tym tekście Przybylak czyni ukłon w stronę polskich rolników konwencjonalnych, uznając, iż dlatego, że pryskają mało zasługują na tytuł prawdziwego rolnictwa. Jeśli bowiem chodziłoby mu tylko o certyfikowane gospodarstwa ekologiczne to w Austrii jest ich znacznie więcej niż w Polsce. Strategia krytyki zachodniego rolnictwa przemysłowego, służy prawdopodobnie zjednywaniu zwolenników rolnictwa ekologicznego w Polsce.

Świat społeczny rolnictwa konwencjonalnego obejmuje m.in. agrobiznes grupujący potężne zakłady azotowe, państwowe instytucje zainteresowane chemizacją rolnictwa (np. Instytut Ochrony Roślin z Poznania, Instytut Uprawy Nawożenia i Gleboznawstwa z Puław czy Instytut Budownictwa i Elektryfikacji Rolnictwa z Warszawy), silne partie polityczne, duże związki zawodowe, instytucje edukacyjne: akademie rolnicze, wyższe szkoły agrobiznesu, krajowe duszpasterstwo rolników. W swoim dyskursie rolnicy konwencjonalni raczej nie dostrzegają istnienia partnerów sporu, mówi się o "interesach polskich rolników", "dotacjach dla polskich rolników", "krajowej pielgrzymce rolników", wytwarzając wrażenie, iż wszyscy rolnicy stanowią pewną grupę zawodową, mającą wspólne wartości i interesy. Firmy agrochemiczne, będące kluczowymi aktorami społecznego świata rolnictwa konwencjonalnego posługują się reklamami, zachęcającymi rolników do stosowania środków chemicznych. W reklamie Zakładów Chemicznych Police S.A. czytamy:

Podobnie jak ludzie, rośliny także maja swoje marzenia, śni się im przyjazna WODA, która ugasi ich pragnienia. A przede wszystkim polickie NAWOZY, bez których nawet najlepsza ziemia nie da dobrego plonu. Nie wystarczq im moje opiekuńcze dtonie. 
Reklama ta dąży wprost do negacji rolnictwa ekologicznego (polickie NAWOZY, bez których nawet najlepsza ziemia nie da dobrego plonu), wykazania, iż nawozy czy środki chemiczne są niezbędnym składnikiem produkcji rolnej. W owej reklamie dochodzi do antropomorfizacji rośliny przeprowadzonej jednak nie na użytek docenienia wewnętrznej inteligencji ekosystemów, lecz perswazyjnemu przekonywaniu, iż roślina marzy o wytwarzanych przez człowieka nawozach.

Podstawowymi argumentami wysuwanymi przez rolników konwencjonalnych w sporach z rolnictwem ekologicznym są teoria ekologiczności calego polskiego rolnictwa i teoria niewydajności rolnictwa ekologicznego. Teoria ekologiczności ma pewne zaplecze w nauce. Specjaliści od ekonomiki rolnictwa Augustyn Woś i Józef Zegar w swej publikacji Rolnictwo Spolecznie Zrównoważone opowiedzieli się za ekologizacji polskich gospodarstw rolnych. Niemniej przytoczony przez nich argument o unikalnych przyrodniczych walorach polskich obszarów wiejskich i stosunkowo mniejszej chemizacji krajowego rolnictwa może być wykorzystywany przeciwko rolnictwu ekologicznemu. Posłuchajmy argumentacji wspomnianych naukowców:

Szybkie rozszerzenie się rynku na produkty rolnictwa ekologicznego stanowi szanse dla polskiego rolnictwa. Mamy bowiem znaczna przewage nad większościq krajów UE z punktu widzenia środowiska, ponieważ nasze rolnictwo jest bardziej naturalne (mniej skażone gleby $i$ wody gruntowe, mniej nawozów chemicznych iśrodków ochrony roślin, więcej tradycyjnych technologii, mniejsza specjalizacja i koncentracja, rozdrobnione gospodarstwa z miedzami, zadrzewieniami, oczkami wodnymi itd.., co obniża efektywność ekonomiczna, $w$ tym wydajność pracy, ale sprzyja zachowaniu różnorodności biologicznej). Te przewagi zwiększyly się jeszcze $w$ okresie transformacji, ponieważ zmniejszyto się nawożenie $i$ stosowanie środków chemicznej ochrony roślin - generalnie zmniejszyla się intensywność gospodarowania, nawet nieco zmniejszyła się produkcja, pojawiło się dużo odłogów, zmniejszyla się ingerencja człowieka $w$ glebę (m.in. ograniczenie zabiegów melioracyjnych) (Woś, Zegar 2002: 6o).

Przeciwnicy rolnictwa ekologicznego argumentują w następujący sposób: Owszem, być może rolnicy ekologiczni produkuja zdrowsze plody, ale polscy konsumenci nie maja potrzeby sięgania po ich drogie produkty, gdyż całe polskie rolnictwo jest "ekologizujące", przecież zawsze u nas pryskano mało z przyczyn ekonomicznych. Polska żywność jest zdrowa, to na Zachodzie pryskajq dużo 
i produkują sztuczną żywność. Argument o względnej naturalności całego polskiego rolnictwa może służyć do motywowania, aby dokonać kroku naprzód w kierunku rolnictwa ekologicznego (bo mamy stosunkowo niewiele roboty) lub wręcz przeciwnie może być wykorzystany do zachęcania do zatrzymania się $\mathrm{w}$ miejscu (bo jest stosunkowo zdrowo). Propagator rolnictwa ekologicznego prof. Mieczysław Górny (2002) zgadzał się z konstatacją, iż ujmowane jako całość polskie rolnictwo jest zdrowsze niż zachodnie, lecz podkreślał również, iż fakt ten nie jest efektem ani większej świadomości ekologicznej polskich rolników, ani jakiejkolwiek rządowej strategii ograniczania chemizacji rolnictwa, lecz wynika jedynie z biedy rolników. Zwracał on uwagę, że tymczasem w ramach pomocy unijnej przekazywanej Polsce za pomocą Fundacji Rozwoju Polskiego Rolnictwa (FDPA), polskim rolnikom przekazywano pestycydy, $w$ tym silne trucizny, które ani $w$ USA ani $w$ krajach EWG nie znajdowaty się $w$ wolnej sprzedaży (Górny ibidem: 120). Rolnicy ekologiczni $\mathrm{w}$ ramach walki z wizją ogólnie zdrowego polskiego rolnictwa, przedstawiają wizję przechemizowanego polskiego rolnictwa konwencjonalnego. $\mathrm{W}$ przypadku analizy historii konwersji na metody ekologiczne, szerzej omówienie znaczenie okresu szalonego pryskania, dojścia do granic absurdu, aby nawrócić się na ekologiczne metody ${ }^{2}$.

Kolejną ideą przytaczaną $\mathrm{w}$ obronie rolnictwa ekologicznego jest idea odmiennego smaku produktów ekologicznych, który również później poddam analizie. Walka pomiędzy wizjami powoduje, że obydwie grupy sięgają po autorytet nauki $\mathrm{w}$ rozstrzyganiu sporów. Jedna $\mathrm{z}$ badanych rolniczek przytoczyła badania naukowców z SGGW jako argument na lepszą jakość jabłek z sadów ekologicznych:

Bardzo, bardzo bym chciała żeby jak najwięcej rolników przeszło na to, bo chemia robi straszne rzeczy, zreszta te owoce, które sq nawożone i pryskane, one maja kilka razy mniej witaminy $C$, nawet takie badania moge ci udostępnić z $S G G W$ z Warszawy, gdzie jest badana zawartość witaminy $C w$ owocach $z$ sadu ekologicznego i z sadu konwencjonalnego, no to jest spora różnica, tam jeszcze też badane sq inne sktadniki.

Ważnym wymiarem areny sporu rolnictwa ekologicznego z konwencjonalnym jest kwestia wielkości gospodarstw. Eko-rolnicy to posiadacze niskopowierzchniowych gospodarstw, produkujący płody o niekwestionowanej

\footnotetext{
${ }^{2}$ Zagadnienie to dokładnie opisuje w rozdziale IV niniejszej pracy: podrozdział 3 Proces stawania sie rolnikiem ekologicznym.
} 
jakości przeciwko posiadaczom wielkopowierzchniowych gospodarstw. Myśli ekologicznej towarzyszyła od samych początków idea lokalności i hasło "małe jest piękne" znane od czasu opublikowanej w 1973 roku książki ekonomisty i prekursora ekologii politycznej Ernsta Friedricha Schumachera Małe jest piękne. Spojrzenie na gospodarkę z założeniem, że człowiek coś znaczy. Julian Osetek, polski prekursor biodynamiki dysponował jedynie trzema hektarami ziemi, typowe gospodarstwo ekologiczne ma około 10 ha. Rolnicy ekologiczni posiadający więcej ziemi mówią o tym z pewnym zażenowaniem, podkreślają, iż to lasy i łąki stanowią znaczną część ich gospodarstwa.

Podkreślanie odmienności od rolników konwencjonalnych jest ważnym elementem procesu budowania i podtrzymywania tożsamości rolników ekologicznych, którzy odczuwają brak reprezentacji politycznej. Oto jak jeden z rolników wskazał mi na poczucie bycia ignorowanym przez polityków:

Spójrz, Lepper (ówczesny minister rolnictwa -PB) kłóci się z Gilowska (ówczesna minister finansów $-P B$ ) o to, kto się zna na rolnictwie. Lepper powiedzial jej: pani nic nie wie o rolnictwie. A Gilowska mu na to, że ona to doktorat z ekonomii rolnictwa zrobita $i$, że to wystarczy... Lepper stusznie jej przygania, że zna rolnictwo tylko teoretycznie. Ale i on, jakie rolnictwo on zna? Toż to jest farmer, co ma takie pojęcie, jak wszyscy konwencjonalni, strusie $i$ bizony z Ameryki se sprowadza, nic o prawdziwym rolnictwie nie wie...(podkr. $P B$ ).

$\mathrm{W}$ analizowanej wypowiedzi mamy do czynienia z procesem wyznaczania granic społecznego świata. Rolnik stwierdza, iż tak politycy - akademiccy, jak i politycy o chłopskim rodowodzie nie należą do społecznego świata rolnictwa ekologicznego, nie znają jego problemów, nie potrafią realizować jego interesów. Hodowanie strusi czy bizonów to praktyki nieakceptowane w ramach badanego społecznego świata, gdyż rolnicy ekologiczni dążą do uprawy lokalnych zbóż, owoców i warzyw oraz chowu zwierząt tradycyjnie charakterystycznych dla obszaru Polski czy ich regionu. Częstą praktyką jest odszukiwanie dawnych gatunków roślin czy ras zwierząt. Egzotyczne gatunki zwierząt sprowadzane przez rolników konwencjonalnych uchodzą za sprzeniewierzanie się kulturze, tradycji i mądrości Natury. Przeszczepianie bizonów czy strusi na polski grunt świadczy o antropocentryzmie, założeniu, iż człowiek jest Panem przyrody i sytuuje się w ramach starego scjentystycznego paradygmatu, zachęcającego do manipulowania tymi prawami. Jest to perspektywa 
bliska Nowej Atlantydzie Francisa Bacona, gdzie można znaleźć triumfalne zapowiedzi o człowieku krzyżującym wszystkie gatunki i zmieniającym prawa przyrody. Nowy holistyczny, ekologiczny paradygmat, za którym optują rolnicy ekologiczni, zakłada pokorę wobec przyrody i jej uważną obserwację, dostosowywanie upraw do rytmów i praw Natury.

1.3 Rolnicy pót-ekologiczni jako obiekt graniczny

W latach 1990-ych sami przedstawiciele badanej grupy społecznej - rolnicy ekologiczni - zajmowali się wyznaczaniem granic swego świata. Dziś, choć ich sytuacja jest prawnie uregulowana, działalność legitymizacyjna państwa może wchodzić w konflikt ze społeczną legitymizacją i definicją tożsamości dokonaną przez samych rolników. Przykładu rozbieżności w wytyczaniu granic społecznego świata pomiędzy instytucjami publicznymi dostarcza wypowiedź pewnej rolniczki ekologicznej:

Teraz tak jest $w$ tych przepisach unijnych, że możesz mieć połowe gospodarstwa ekologicznego, że konkretna działkę możesz mieć. To jest dziwne, nam się nie podoba. Mówił mi ten, co byl na kontroli, mówił mi, że rolnik może zglosić i opryskać działkę, a potem przechodzi okres trzech lat i po trzech latach, jak nie będzie pryskat, to znów ma statut ekologiczny. Także jak do kontroli przyjeżdża "Bioekspert" to mogę pokazać tu mam ekologię i tu, a tu nie mam (śmiech). Ale nam się to nie podoba, jak rozmawiam z rolnikami, bo jak jest ekologia to już powinna być na całym gospodarstwie.

Faktycznie, obecnie prawodawcy polscy i unijni, jak i niektóre motywowane zyskiem firmy certyfikacyjne dopuszczają sytuacje istnienia rolników pótekologicznych czyli rolników, którzy tylko część swej ziemi decydują się przeznaczyć na uprawy ekologiczne, jest to jednak obwarowane rygorem spełnienia określonych warunków (np. trzeba uprawiać odmienne rośliny na polach ekologicznych i konwencjonalnych, wymagana jest również określona odległość pomiędzy polami, itd.). W tym wypadku mamy do czynienia z konfliktem wizji rolnictwa ekologicznego jako zawodu - jest to wizja, którą posiadają prawodawcy, dla których podstawowe działanie analizowanego świata społecznego - prowadzenie upraw ekologicznych jest działaniem o charakterze gospodarczym. W takiej definicji, nie stanowi problemu, że wykonawca tego działania podejmuje się jakichkolwiek innych aktywności 
gospodarczych, w tym uprawy rolnictwa konwencjonalnego. Odmiennie, w przypadku doświadczonych rolników ekologicznych, owe podstawowe działanie ma wymiar kulturowy, filozoficzny, polityczny, ideologiczny, duchowo-religijny, i tak dalej. W perspektywie eko-rolników, występuje pełne zrozumienia i akceptacja sytuacji, gdy rolnik ekologiczny nie jest w stanie utrzymać się wyłącznie ze swego gospodarstwa i musi uzupełniać dochody pracując poza gospodarstwem, na przykład jako robotnik, nauczyciel lub instruktor jazdy. Jednakże równoległe prowadzenie uprawy konwencjonalnej poddawałoby w wątpliwość autentyczność jego ekologiczności, gdyż kłóciła by się z misją eko-rolnictwa. Decyzja o nie pryskaniu upraw będącą jednym z podstawowych założeń ideologii rolnictwa ekologicznego powinna być przemyślanym wyborem ideowym a nie decyzją ad hoc.

Wybór rolnictwa ekologicznego jawi się rolnikom - długoletnim praktykom jako danie świadectwa wizji świata, za jaką się optuje. Stąd, obiekty graniczne w postaci rolników pól-ekologicznych i niekonsekwentnych rolników ekologicznych budzą wśród nich pewną niechęć. Posługując się analogiami, można by powiedzieć, że wybór pomiędzy rolnictwem ekologicznym i rolnictwem konwencjonalnym to wybór tak ważny jak wybór religii czy systemu politycznego, którego stajemy się zwolennikami. Tak, jak ludzie balansujący pomiędzy poparciem dla kapitalizmu i poparciem dla socjalizmu lub pomiędzy przyjęciem wiary i niewiarą spotykają się z niezrozumieniem obydwu antagonistycznie nastawionych grup, podobnie jest w przypadku rolników balansujących między rolnictwem ekologicznym i konwencjonalnym. Wydaje się, że decydującym punktem jest świadectwo wiary, socjaliści chętnie zaakceptują w swych szeregach chcącego się nawrócić kapitalistę, wytłumaczą mu założenia swojej doktryny, chrześcijanie przyjmą chętnie nawróconego ateistę, a rolnicy ekologiczni bardzo chętnie wesprą rolnika konwencjonalnego $\mathrm{w}$ procesie przestawiania się na ekologiczne metody. Niemniej, w tej dziedzinie oczekiwany jest jednoznaczny wybór, osobnicy, co pala panu Bogu świeczkę, a diabłu ogarek nie mogą liczyć na pełną akceptację żadnej z grup.

\subsection{Rolnictwo integrowane jako obiekt graniczny}

Innym obiektem granicznym jest fenomen tzw. rolnictwa integrowanego, które mimo intensywnych kampanii promocyjnych przyjęło się $\mathrm{w}$ Polsce $\mathrm{w}$ niewielkim 
zakresie jedynie w uprawach sadowniczych. Na Zachodzie idea takiego rolnictwa pojawiła się już w latach 6o-tych. ubiegłego wieku jako rodzaj krytycznej reakcji na pierwsze doniesienia o zgubnych skutkach stosowania herbicydów i pestycydów, zdemaskowanie szkodliwości środków takich jak DDT. Był to pomysł na ograniczenie niekorzystnych wpływów wprowadzanych do rolnictwa sztucznych środków. Istotą tego rolnictwa nie była jednak rezygnacja ze stosowania herbicydów czy pestycydów, lecz wprowadzenie zasady tak mało jak to możliwe $i$ tak dużo jak jest niezbędne (Górny 2002: 178). Gdy nie było poważnego zagrożenia szkodnikami propagatorzy tej formy rolnictwa proponowali stosowanie nawozów i technik naturalnych, w sytuacji zagrożenia dopuszczali środki chemiczne. Rolnictwo integrowane jest rodzajem trzeciej drogi pomiędzy opartym o sztuczne nawozy syntetyczne i środki ochronne rolnictwem technologicznym, a rolnictwem ekologicznym. W Polsce rolnictwo to było promowane intensywnie w latach 90, lecz odniosło bardzo nieznaczne efekty.

Mieczysław Górny (2002), czołowy ideolog polskiego rolnictwa ekologicznego dokonał krytyki rolnictwa integrowanego, oceniając je jako nowe przebranie rolnictwa technologicznego. Zauważył, iż w przygotowanie wykładni rolnictwa integrowanego tzw. Kodeksu Dobrej Praktyki Rolniczej zaangażowane były instytucje zajmujące się chemizacją rolnictwa, takie jak propagujący nawozy azotowe Instytut Uprawy Nawożenia i Gleboznawstwa z Puław czy Instytut Budownictwa i Elektryfikacji Rolnictwa z Warszawy (s. 179). Krytycznie ocenił fakt, iż $w$ rolnictwie integrowanym zalecenia agrotechniczne dotyczq określonych roślin uprawnych, a nie gospodarstwa jako catości, że dq̨ży się do maksymalizacji produkcji, a jej efekty ocenia wyłącznie ilościowo (Górny ibidem: 181). Ponadto jego niepokój wzbudzał fakt braku całkowitego zakazu stosowania najbardziej trujących środków. Górny miał świadomość, iż rolnictwo integrowane mogłoby stanowić rodzaj konkurencji dla ekologicznego, gdyż swoje narodziny zawdzięcza podobnym troskom. Niemniej, rolnictwo to nie stawia sobie za cel zachowania równowagi ekologicznej i najwyższej jakości żywności, lecz, jak konwencjonalne, jej największą ilość. Wedle omawianego autora, koncepcje rolnictwa integralnego wynikaja z przemyśleń tych polityków rolnych i przemystowców produkujacych środki produkcji dla rolnictwa, którzy mając na względzie bardziej własny interes niż interes spoleczeństwa i przyrody, próbujq wykorzystać wzrastającq wśród ludności świadomość potrzeby ochrony środowiska i postanowili sprzedawać procesy produkcyjne i ich produkty jako "przyjazne dla środowiska", chociaż takimi nie sq (Górny ibidem). 
Stosunek Górnego do rolnictwa integrowanego nie powinien nas dziwić, gdyż bardziej przychylna postawa świadczyłaby o jego niekonsekwencji i niespójności. Ostatecznie rolnictwo ekologiczne stawiało stanowczą barierę środkom chemicznym, opowiadało się za holistycznym, systemowym spojrzeniem uwzględniającym wszystkie zachodzące $\mathrm{w}$ środowisku zależności, podczas gdy rolnictwo integrowane zmierzało jedynie do ograniczenia stosowania chemii, utrzymując aksjologię rolnictwa konwencjonalnego (wydajność, ilość, antropocentryzm). Górny jedynie widział sens takiego rolnictwa jako tymczasowego etapu na drodze do całkowitej ekologizacji rolnictwa konwencjonalnego. Nie mial nic przeciwko temu, aby stworzony przez propagatorów rolnictwa integrowanego Kodeks stał się prawnym wymogiem dla konwencjonalnych, a nie jedynie listą życzeń. Rzeczywiście rolnictwo integrowane bywało etapem na drodze ku rolnictwu ekologicznemu $\mathrm{w}$ dwu przypadkach moich rozmówców, prowadzących uprawy sadownicze. Oto jeden z fragmentów narracji łódzkiego ekorolnika - sadownika:

Chciatem uprawiać mój sad $w$ pierwszej fazie $w$ technologii integrowanej produkcji, czyli z chemia, ale tylko $w$ uzasadnionych przypadkach, tak to można nazwać, czyli jak to się teraz tadnie mówi: IPO, niektórzy sadownicy stosują te techniki, ale // odbylem 3 przeszkolenia $w$ tej branży, organizowane przez ODRy, też doszedlem do wniosku, że akurat $w$ uprawie porzeczki stosuje się tak dużo chemii przy plantacjach towarowych, że to IPO na dobra sprawę nie rozwiązuje problemu. Trzeba do tego podejść inaczej, przez jakieś tam wycinanie, odmiany odporne, tak się dobrze ztożyło, że ja nie wiedzac o tym jeszcze nabylem odmiany odporne, odporne na grzyby przede wszystkim, i zostawilem chemie, jestem teraz $w$ trzecim roku przestawiania i efekt taki jest, że groźny szkodnik przy porzeczce to jest wielkobukowiec, na którego nie ma preparatu, który by go skutecznie zlikwidowat $i$ efekt $u$ nich jest mizerny, tego wielkobukowca jest tyle samo u nich, co u mnie, ciesze się więc, że moje porzeczki rosna wolne od chemii, bo chemia nic nie daje, a truje.

W tym wypadku rolnik przedstawia sprawę od strony pragmatycznej, próbował rolnictwa integrowanego, lecz efekty były mizerne wobec kosztów i wariant ekologiczny okazał się mniej kosztowny i przy okazji zdrowszy. Wybór ekologiczny wynikał $\mathrm{z}$ racjonalnego osądu. $\mathrm{Z}$ perspektywy lat rolnik mówi o rolnictwie integrowanym jako fazie, postrzega je jako ważny etap na drodze do eko-rolnictwa. 
Od kilku lat w kontekście instytucjonalnym rolnictwa ekologicznego ważną rolę odgrywają ciała eksperckie - firmy certyfikujące gospodarstwa i produkcję, im bowiem powierzone jest oficjalne etykietowanie gospodarstw, mają władzę orzekania, czy dane gospodarstwa, określone wytwory, a nawet sklepy są ekologicznymi czy nie. Firmy te dodatkowo pełnią również funkcje komunikacyjne - informując rolników o organizowanych targach, festynach, przekazując informacje handlowe. Firm tych jest obecnie siedem, są to: EKOGWARANCJA PTRE sp. z o.o., Jednostka Certyfikacji Produkcji Ekologicznej PNG sp. z o.o., COBICO sp. z o.o, BIOEKSPERT sp. z o.o., BIOCERT MAŁOPOLSKA sp. z o.o., Polskie Centrum Badań i Certyfikacji - Oddział w Pile i AGRO BIO TEST sp. z o.o (Źródło: IJHAR-S). Naczelną funkcją tych firm jest wydawanie i cofanie certyfikatów zgodności w zakresie produkcji rolnej, którego skutkiem jest wprowadzenia do obrotu rynkowego produktów rolnictwa ekologicznego. Celowi temu służą kontrole ekologiczności gospodarstw, oprócz corocznej kontroli oficjalnej, owe firmy mają prawo do dokonania w każdej chwili niezapowiedzianej kontroli. Pewien rolnik ekologiczny określił jednostki certyfikacyjne mianem naszej policji - termin świadczący o oswojeniu się z działalnością tych jednostek i ich integralnej roli w świecie społecznym (nasza) i nacisku na śledczo-kontrolny wymiar ich działalności.

W świetle przyjętych ram teoretycznych, ciała eksperckie posiadły pewne władze legitymizacyjne. Dawniej, certyfikacją zajmowali się jedynie sami ekorolnicy zrzeszeni w Stowarzyszenie Producentów Żywności Metodami Ekologicznymi EKOLAND - przyznanie certyfikatu Stowarzyszenia stanowiło zaproszenie do wstąpienia do nowo powstającej grupy zawodowej. Choć certyfikat EKOLANDu widnieje ciągle na licznych produktach rolnych i jest najlepiej rozpoznawanym certyfikatem przez konsumentów, nie ma wartości prawnej. Oto, jak ową przemianę opisuje jeden z moich rozmówców - rolników ekologicznych:

to już Ekoland nie ma swoich regul, bo teraz sq unijne wymogi, już obowiązuja. One weszty dwa lata temu, jak weszliśmy do Unii. Nie pamiętam $w$ tej chwili numeru, ale jest cała książka, 90 stron tych przepisów. To jest charakterystyczne, że jak Ekoland zaczynat swa działalność to były 4 strony wymogów ekologicznych. Teraz to się rozbudowato do większego podręcznika. Ale w sumie to jest to samo, te wymogi sq (...), no sq bardziej szczegółowe. Bo tak jak na poczatku to było, żadnej chemii, nie ma dyskusji, nic. Teraz sa 
wtych wymogach niektóre rzeczy dopuszczone, na przykład siarczan miedzi, tam do jakiejś ochrony $w$ sadzie jest dopuszczony. My nie dopuszczaliśmy, byt to zakazany owoc.

Proces dopuszczania przez ustawodawców pewnych form chemizacji gospodarstw ekologicznych, poczytywanych co prawda za najmniej szkodliwe, ekorolnicy często wiążą z lobbingiem koncernów agrochemicznych, które chcąc odpowiedzieć stawianym coraz częściej przez klientów wymogom ekologiczności próbują nawiązać walkę o znaczenie terminu, proponując bardziej "liberalną" definicję. Jeden eko-rolnik podzielił się ze mną takim stwierdzeniem:

Czy widziateś gospodarstwo ekologiczne, które miałoby z 1000 hektarów? Moje gospodarstwo ma 10 ha i cały mój czas jemu poświęcam, pomagaja dzieci $i$ żona też czasem pomaga. To jest niewyobrażalny ogrom roboty, choćby samo pielenie trzy razy do roku. A ci, co zgłaszaja jakieś setki hektarów upraw ekologicznych to sa gospodarstwa zmechanizowane, coraz szerzej chemię można stosować... Pytam się: gdzie jest tam ta ekologia?

Zarządzanie kryteriami ekologiczności gospodarstw przez państwo i profesjonalne agendy wzbudza krytykę czołowego ideologa polskiego ekorolnictwa Zbigniewa Przybylaka (2006b). Krytykuje on system dotacji premiujący, jego zdaniem, bardziej monokulturowe i wielkoobszarowe gospodarstwa, zamiast najbardziej ekologicznych z samej istoty make tradycyjne ekologiczne gospodarstwa rolne o różnorodnych uprawach i chowie zwierząt oraz małego przetwórstwa $w$ gospodarstwach (s. 1.). Główne ostrze krytyki redaktor naczelny Eko Arki kieruje w nieuzasadnione zdroworozsqadkowo coraz bardziej wygórowane i radykalne wymagania sanitarno-weterynaryjne. Zachęca on eko-rolników do obywatelskiego nieposłuszeństwa, głosząc, iż rolnicy tamiacy absurdalne prawo $w$ imię ratowania z miłościq życia drugiego człowieka sq swego rodzaju Znakiem Sprzeciwu, Znakiem Prawdy $w$ oceanie powszechnego lęku i zamętu we wspótczesnym świecie (Przybylak ibidem). Podsumowując, doświadczeni ekorolnicy z misją bardziej ufają własnemu pojmowaniu ekologiczności niż wszelkim ekspertyzom. Własna opinia i wierność zasadom etycznym jest dla nich ważniejsza niż posiadanie prawnego potwierdzenia tożsamości ekorolnika. 
Biodynamika jest jedną $\mathrm{z}$ głównych filozofii rolnictwa ekologicznego, przedstawiona szerzej $\mathrm{w}$ rozdziale III. Wokół biodynamiki narosło wiele mitów i opowieści. Wedle pozytywnie nastawionej wobec niej rolniczki, warzywa produkowane za pomocą owych metod, smakują inaczej: mają coś jeszcze maja dodatkowego, one sa takie bardzo...tak, nie tyle słodkie, co jakieś bardzo sycace te warzywa, także warto spróbować.

Stosunek do biodynamiki to jedna z głównych aren sporów społecznego świata rolników ekologicznych. Istotą spornej kwestii (issue) jest, że biodynamika jest kompleksową, filozoficzną perspektywą, nie wolną od pewnych założeń metafizycznych, które wzbudziły wiele zastrzeżeń i lęku polskich ekorolników, ceniących sobie konkret, spójność, klarowność poglądów i katolicką wiarę. Stanowisko afirmatywne wobec biodynamiki oznacza szacunek dla niej jako filozofii prowadzenia gospodarstwa w pełnej jedności z siłami kosmicznymi, jakkolwiek rolnicy mogą przyjąć, iż jeszcze nie są gotowi na trudne wyzwania, jakie owa filozofia przedstawia. Stanowisko negatywne oznacza ugruntowaną na katolickim światopoglądzie podejrzliwość wobec biodynamiki jako emanacji antropozofii Steiner, uznawanej za rodzaj herezji, interpretowanej jako zastapienie Boga przez człowieka.

Biodynamika stwarzała problem kognitywny umiejscowienia sił przyrody w katolickim uniwersum symbolicznym. Pewien rolnik wyznał mi: Mnie ta biodynamika to nie grała, coś śmierdziała, bo oni to chcieli żebym uwierzyt, że całe życie pochodzi od Matki - Ziemi i Ojca - Kosmosu, a dla mnie to był grzech wobec mojej wiary. Biodynamiczne pojęcia Kosmosu, Matki Ziemi, sił przyrody, planet wchodziły w kolizję z katolickim uniwersum symbolicznym. Inny rolnik dobrze pokazuje tą sytuację: Ja byłem nauczony, że sq w świecie dwie sity: Bóg i szatan. Nie ma żadnej trzeciej, neutralnej siły kosmicznej, stąd nie mogłem przyjać tej biodynamiki i pana Steinera. Kolejny z badanych rolników porzucił zaś metody biodynamiczne w momencie, gdy jego nauczyciele zapoznali go z filozoficznymi zasadami antropozofii Steinera, co spowodowało kolizję z katolickim światopoglądem mego rozmówcy: 


\section{B. Czy stosuje Pan te wskazania biodynamiczne?}

R. Przestałem. Na poczattku, jak ci wykładowcy (...) uczyli nas, przede wszystkim ci Niemcy, Szwajcarzy rolnictwa biodynamicznego i myśleliśmy, że się na tym świat kończy. I $w$ pewnym momencie zaczęli oni takie wymogi stawiać, że ta biodynamika jest związana z innym światopogladem. Antropozofia to się nazywa. I, że nie można stosować biodynamiki bez przejścia na ta filozofię. Ponieważ ja jestem katolikiem to mi się nie // wtedy się wycofatem. Tak robitem do tej pory, te preparaty $i$ to używatem przez parę lat. Ale z chwila, gdy mi to powiedzieli, że to tak musi być, żeby to dobrze działało, to większość Polaków, rolników $w$ Polsce, odeszła od biodynamiki.

Trzeba przyznać, że obawy rolników przywiązanych do katolickiego światopoglądu mają logiczne postawy. Rzeczywiście Steiner postrzegał rolnictwo ekologiczne jako element szerszego projektu zmiany społecznej obejmującej przebudowę światopoglądu i instytucji społeczno-gospodarczych. Steiner zajmował się również ezoteryką, astrologią, śmiało głosił teorie na temat ciał mentalnych i astralnych, bronił idei reinkarnacji. Wydestylowanie specjalistycznej wiedzy rolniczej z całego kontekstu jego myśli mogło być czymś, co nie spotkałoby się z uznaniem samego Steinera, przywiązanego do holizmu. W tym świetle opór polskich rolników wydaje się zrozumiały.

W relacji łódzkiego rolnika ekologicznego, który niedawno przestawił się na metody ekologiczne, biodynamika jawi się jako kolejny stopień wtajemniczenia, na który być może się kiedyś zdecyduje:

Byłem na spotkaniu z Demeter, spotkaniu z niemieckimi rolnikami, to jest biodynamiczne rolnictwo, stopień wyżej bardziej skomplikowane. To jest takie czary-mary, my to nazywamy, na razie to my jesteśmy na etapie przestrzegania podstawowych tych praw. To jest, to sq po prostu arkana, wyższa szkoła, to tak jakby dać dziecko od razu na studia, będzie grzecznie siedzieć i udawać, że wie, ale najpierw musi być podstawówka, gimnazjum, nie ma pośpiechu...Trzeba nie tylko wiedzieć, ale i rozumieć.

Deklaracja ta jest ważnym dowodem respektu dla biodynamiki ze strony przedstawiciela kolejnego "pokolenia" eko-rolników.

Jakkolwiek, tym bardziej warto tu wymienić dzieło swoistego pogodzenia pewnych elementów biodynamiki z doktryną katolicką, dokonane przez Zbigniewa Przybylaka, redaktora naczelnego magazynu "Eko - Arka", lidera ruchu rolników ekologicznych, silnie związanego z Kościołem Katolickim. Przybylak, choć potępia 
antropozofię, widzi potrzebę czerpania z mądrości bożej zawartej w rytmach przyrody i stąd, zwyczajem biodynamików, wydaje co roku kalendarz księżycowy. Jako, że Przybylak jest praktykującym katolikiem, to co proponuje uznawane jest za światopoglądowo bezpieczne. Oto przykład narracji łódzkiego eko-rolnika: Stosuje kalendarz Przybylaka, bo to co on publikuje jest bezpieczne, jest robione pod znakiem krzyża i Chrytusa.

\section{Wartości rolnictwa ekologicznego - pytania o istotę.}

2.1 Wizja aksjologiczna rolnictwa ekologicznego jako nowego ruchu społecznego

Encyklopedyczne definicje ekorolnictwa, takie jak ta oferowana przez Wikipedię akcentuje przede wszystkim jego techniczny aspekt, choć zwracają uwagę na jeden aspekt świadomościowy - imperatyw ograniczania ingerencji człowieka w przyrodę: Ekorolnictwo, alternatywny dla rolnictwa konwencjonalnego system gospodarowania zmierzający do poprawy jakości i zdrowotności artykułów żywnościowych $i$ innych produktów rolnych, zrównoważony ekologicznie i ograniczający ingerencję czlowieka $w$ ekosystem gospodarstwa, co hamuje proces degradacji siedliska rolniczego (www.wikipedia.pl). Niemniej, tego typu definicje spisane za pomocą abstrakcyjnych, naukowych terminów są niejako zewnętrzne wobec języka, jakim posługują się sami eko-rolnicy. Z narracji eko-rolników dowiedzieć się możemy, że najistotniejszym celem w rolnictwie ekologicznym nie jest poprawa jakości i zdrowotności artykutów żywnościowych i innych produktów rolnych, lecz produkowanie zdrowej, prawdziwej żywności czy dbanie o to by byly zdrowe rośliny, zdrowe zwierzęta $i$ zdrowi ludzie. Nie usłyszałem sformułowań o ograniczaniu ingerencję czlowieka $w$ ekosystem gospodarstwa, co hamuje proces degradacji siedliska rolniczego, lecz o miłości do Przyrody i współpracy z nią. Czy zatem błędne są podręcznikowe definicje rolnictwa ekologicznego? Nie uważam ich za całkiem błędne, gdyż w pewien sposób przybliżają nam ważne cechy badanego zjawiska, lecz z całą śmiałością twierdzę, iż umykają one codziennym doświadczeniom polskich rolników ekologicznych i pomijają ważny komponent ideologicznoemocjonalny, niezwykle istotny dla rolników. Ponadto, warto zwrócić uwagę, iż definicje encyklopedyczne definiują rolnictwo ekologiczne przede wszystkim metodą negatywną: nie dla chemii, nie dla ingerencji człowieka. W opowieściach eko- 
rolników dostrzeżemy w większym stopniu pozytywny wymiar ich decyzji: miłość i symbiotyczne relacje z przyrodą. Ponadto, uważam, że bardziej niż o ograniczenie ingerencji człowieka, chodzi o całkowite przeobrażenie tych relacji, w której człowiek może ciągle odgrywać istotną rolę, lecz stosując jedynie środki z repertuaru przyrody (np. preparaty mikroorganiczne).

Zamierzam rozpatrywać rolnictwo ekologiczne jako fenomen społeczny, uwzględniając jednak wedle wskazań Simmla rolę Przyrody jako partnerki interakcji. Przede wszystkim planuję przyjrzeć się w toku pracy społecznemu i subiektywnemu aspektowi ekorolnictwa. W jaki sposób sami eko-rolnicy kreują własną tożsamość? Ważnym pytaniem jest, czy rolnicy ekologiczni traktują swoją działalność jako formę zawodu, przedsiębiorczości czy też rodzaj powołania, projekt ideowy. Specyfika rolnictwa ekologicznego związana jest nie tylko z faktem, iż rolnictwo dysponuje specjalnym statutem niesprowadzalnym do kolejnej działalności biznesowej, ze względu na strategiczne znaczenie wyżywienia dla społeczeństwa.

Rolnictwo ekologiczne, rozpatrywane jako ruch społeczny eko-rolników, należałoby do tzw. nowych ruchów społecznych. Teoria nowych ruchów społecznych, wypracowana przez takich autorów, jak Alberto Melucci i Bert Klandermans odwołuje się do ruchów społecznych powstałych począwszy od dekady lat 1960. Nie dawały się one interpretować w prostych kategoriach konfliktu klasowego i walki o władzę, należało je odnieść raczej do konfliktu wartości, gdzie reprezentowały wartości antymodernizacyjne, nie podzielając wiary w stały postęp i zwracając uwagę na dezintegrujący wpływ gwałtownej modernizacji i industrializacji na życie społeczne. Obrona naczelnych wartości była dla nich ważniejsza niż walka o władzę. Nowe ruchy społeczne, takie jak ruch ekologiczny, wskazywały na negatywne skutki modernizacji $\mathrm{w}$ postaci zerwania więzi społecznych, osłabienie bezpieczeństwa emocjonalnego jednostek, degradacja środowiska naturalnego. Według Klandermansa, oprócz antymodernizacyjnej orientacji w sferze wartości, ruchy te wyróżnia nowy typ aspiracji - „być” zamiast „mieć”, czyli prymat wartości postmaterialnych, a także nowatorskie formy działania, polegające na samoorganizacji poprzez budowę poziomych struktur o niskim stopniu hierarchizacji (Por. Olechnicki 1998: 35-36). Kolejnym czynnikiem charakterystycznym dla nowych ruchów społecznych jest odmienny skład osobowy, rekrutujący się z osób, które ucierpiały na skutek procesów modernizacji i członków tzw. nowej klasy średniej osób młodych i wykształconych. 
W niniejszym podrozdziale zaprezentuje najważniejsze wartości, jakie stawiają sobie jednostki współtworzące ruch społeczny rolników ekologiczny, będący głównym aktorem społecznego świata rolnictwa ekologicznego. Wartości ukazujące się $\mathrm{w}$ wywiadach dały mi podstawy do wyłonienia hipotezy o postmaterialistycznej orientacji analizowanego ruchu społecznego.

Analityczne wydestylowanie wartości z narracji eko-rolników jest dosyć trudnym zadaniem, gdyż one wzajemnie się przenikają. Oto fragment pierwszej narracji, jaką uzyskałem od rolnika ekologicznego:

To jest sposób na życie. To jest korzystanie z przyrody, tego, co nas otacza, samo życie. Królestwo roślin, zwierząt, mikrobów wzajemnie się żywiq. Cykl zamknięty. Rośliny żywiq się mikroelementami, nimi żywiq się zwierzęta, później z nas po rozlożeniu żywia się mikroby, a po mikrobach wychodza mikroelementy. Cykl zamknięty, tak jak funkcjonuje przyroda, funkcjonuje całe życie.

Trzeba wierzyć $w$ to co się robi. Wiedzieć, jak to funkcjonuje by nie zagubić się w tym wszystkim. Obserwować przyrodę.

W tak krótkim fragmencie nasuwają się trzy wartości: korzystanie z przyrody, czyli świadome uczestnictwo $\mathrm{w}$ systemach ekologicznych, wiara $\mathrm{w}$ sens działania i misji oraz samowystarczalność gospodarstwa, która znalazła wyraz w przedstawionej idei cyklu zamkniętego. Analizując dalsze wywiady stwierdzilem, iż centralną wartością jest miłość do Przyrody, to od niej wychodzą dalsze wartości:

$\rightarrow$ wiara i nowe myślenie

$\rightarrow$ dobro

$\rightarrow$ uczciwość

$\rightarrow$ ratowanie bioróżnorodności

$\rightarrow$ zdrowe i "szczęśliwe" zwierzęta

$\rightarrow$ samowystarczalność

$\rightarrow$ wzajemna współpraca

2.2 Miłość do Przyrody

W narracjach eko-rolników zauważyć można interakcje rolnika z Przyrodą, rolnik umożliwia Przyrodzie swobodny rozwój i w zamian otrzymuje obfite 
wynagrodzenie. W wypowiedzi innego rolnika pojawia się motyw unikania cierpienia i symbiotycznej relacji człowieka i przyrody:

Rolnictwo ekologiczne to jest pewna mitość do Przyrody, bo chemia to jest siła śmierci, zabija te wszystkie owady, drobnoustroje. A w naszym rolnictwie czlowiek nic nie niszczy, nie zabija. Że ja szanuję Przyrodę, a Przyroda pomaga i mnie. Tak to dziata - nikt nie choruje, nikt nie cierpi (podkr. PB).

Warto nadmienić, że rolnicy ekologiczni dokonują zabiegu upodmiotowienia, swoistej antropomorfizacji Przyrody. Przyroda staje się partnerką interakcji, współpracowniczką człowieka, sprawcą działań, w perspektywie rolników ekologicznych ziemia potrafi odczuwać ból spowodowany chemią, potrafi chorować:

Te pierwsze lata byty najgorsze bo po kilku latach stosowania chemii to ziemia, że tak powiem chorowała, spadek płodności do 6o\%, inwazja chwastów, owadów...

Inny eko-rolnik wskazał na kluczowe znaczenie miłości do Przyrody i współpracy z podmiotowo rozumianą Przyrodą jako istotę rolnictwa ekologicznego obok niestosowania środków chemicznych. Miłosny stosunek do Przyrody, którego dowodem jest nie trucie jej sztucznymi środkami i dbałość o nią, powoduje, iż Przyroda staje się sojuszniczką rolnika:

Przede wszystkim to, że nie stosujemy środków chemicznych, na pewno pewna miłość do przyrody, do tych wszystkich drobnoustrojów, tych owadów, taka miłość do przyrody, że czuje się przyjemność, że się widzi tą Przyrodę $w$ stanie nienaruszonym, nie niszczy tych organizmów, że się wspótżyje z Przyroda, że ona też przyroda pomaga człowiekowi, że jak się niszczy tych owadów na przykład przy walce z mszycami nam pomaga biedronka, a jak się pryska chemicznie to się zabija biedronki, zabija się sojuszniczki. Ja pomagam przyrodzie, a przyroda pomaga mnie.

W miłosnym stosunku do Przyrody dostrzec można elementy postawy kontemplacyjnej: czuje się przyjemność, że się widzi ta Przyrodę $w$ stanie nienaruszonym (miłość do Przyrody jako cel). Niemniej, jest również element celowościowo -racjonalny - owa miłość nie tylko jest celem, ale i opłaca się ze względu na owoce, jakie przynosi - efektywniejsze funkcjonowanie gospodarstwa (miłość do Przyrody jako środek). 
Identyfikacja rolnictwa ekologicznego z siłami dobra jest czymś bardzo powszechnym wśród rolników ekologicznych i dlatego Eko Arka bardzo skutecznie do nich trafia ze swym przekazem. Znamienna jest tu wypowiedź doświadczonego rolnika ekologicznego i młynarza Piotra Hillara:

Nie chcemy zatrzymać się $w$ rozwoju. Mamy plany na przyszłość, jednak realizować je będziemy z rozwaga. Żyjemy $w$ czasach wielkich możliwości $i$ należy z nich roztropnie korzystać. Zawsze możemy podzielić się swoimi doświadczeniami i stużyć rada innym, początkujacym rolnikom. $Z$ perspektywy czasu stwierdzamy z żona, że w pracy rolnika ekologicznego idea przesłania często finanse. Gdyby byto odwrotnie, na pewno nie udałoby się nam przetrwać. Ale my wierzymy, że dobro zawsze zwycięża (Sottysiak 1995: 102).

W tej wypowiedzi nie ma patosu, lecz są to proste słowa o gotowości pomocy innym eko-rolnikom i konieczności pamiętania, iż rolnictwo ekologiczne to nie tylko zarabianie pieniędzy, ale i zawód z misją. Jest w niej silne przekonanie, o tym, że droga eko-rolników to droga dobra. O dobru jako wartości rolnictwa ekologicznego pisał również szeroko prof. Mieczysław Górny (2002), który w książce Ekorozwój wsi i rolnictwa wyjaśnia, co konkretnie rozumiał przez dobro:

Dobro, to znaczy właściwy stosunek do świata i do ludzi. Właściwy znaczy taki, który jest korzystny nie tylko dla człowieka, ale i dla innych istot. Aby dobro stało się rzeczywistościa, człowiek musi dążyć do jak najlepszego zrozumienia tajemnic życia i musi to życie chronić. Nie tylko dlatego, że inne organizmy sq mu potrzebne, lecz dlatego, że istnieją. Oto współczesna zasada ochrony przyrody: chronić życie dla niego samego, dlatego, że jest, że istnieje. (s. 33, podkr. $P B$ ).

Dobro jak wynika z niniejszego tekstu jest połączone z dwoma kolejnymi wartościami - uczciwością, odnoszącą się do kwestii relacji z klientami, stosunków między ludźmi i ochrony życia zwierząt i dbałości o nie, etyki biocentrycznej (zdrowe i szczęśliwe zwierzęta). Specyficzne rozumienie uosobienia sił dobra przez rolników ekologicznych proponuje Zbigniew Przybylak (2003), redaktor naczelny magazynu Eko Arka, zdaniem którego rodzime gospodarstwa ekologiczne są eko arkami rodzajem Arek Noego, mogących wybawić część ludzkości z przewidywanych przez niego dziejowych kataklizmów (s. 237). 


\subsection{Wiara i nowe myślenie}

Oto jak doświadczony eko-rolnik z Łódzkiego opisuje, co to znaczy być rolnikiem ekologicznym:

Najważniejszym kryterium pierwszym jest gospodarz. Musi swoja głowę przestawić na inne tory myślenia, bo większość rolników jak się spotyka, to tak: to jest niemożliwe by rosło, jak się nie sypie. Musi uwierzyć, że można inaczej. Drugim kryterium jest zakaz całkowity herbicydów, pestycydów, wszelkich środków ochrony roślin. Kolejna rzecz, zakaz wszelkich nawozów. Tylko nawozy naturalne, obornik, kompost. Dopuszczalne sq nawozy mineralne, co sa bezpośrednio kopane z samej ziemi, na przykład wapno, gdzie sa sole fosforowe, $w$ pierwotnej postaci nieprzetworzone fabrycznie i wtedy też byty. Trzecia jest wtaściwa gospodarka napoju i właściwy płodozmian. Tutaj jeżeli wpadna choroby $w$ rolnictwie ekologicznym to nie ma oprysku, ta choroba niszczy wszystko. Żeby tego uniknać, ptodozmian musi być tak utożony by nie następowaty sobie rośliny z tej samej rodziny, co te same szkodniki atakuja. Musi być aby nie przetrwat szkodnik, nie rozwiną się inwazyjnie. Na przykład zboża po zbożu niedobrze by było, musi następować np. roślina motylkowa czy przemysłowa. To jest główny sposób zapobiegania chorobom $i$ szkodnikom w gospodarstwie ekologicznym (podkr. PB).

Zwraca uwagę fakt, iż cytowany eko-rolnik pierwsze miejsce przyznał głowie gospodarza, tym samym kwestia przestawienia się na rolnictwo ekologiczne nie jest sprawą zmiany technologicznej, lecz świadomościowej, związanej z odmienną filozofią stosunku człowieka do Ziemi, zwierząt i upraw. Jednakże, w procesie certyfikacji nie jest rozpatrywane kryterium świadomościowe, należy spełnić określone kryteria techniczne, takie jak redukcja ilości używanych produktów przemysłowych, zapewnianie biologicznej samoregulacji poprzez metody, takie jak płodozmian, stosowanie odpowiednich metod ochrony gleb i wody, prowadzenie odpowiedzialnej gospodarki ściekowej, ochrona siedlisk, itp.

\subsection{Uczciwość}

Ważną, poruszaną niemal w każdej narracji ekorolników z misją wartością jest uczciwość, autentyczność czy też jak częściej mówią: prawdziwość. Kwestia prawdziwości jest ważnym narzędziem wytyczania granic społecznych światów, 
osoby nie będąc prawdziwymi rolnikami, nie są dobrze widziane w ruchu. Niemniej sedno tego, co rozumieją rolnicy przez moralność stanowi uczciwość będąca pojęciem szerokim, odnoszonym tak do relacji z klientami, jak i przyrodą, pojęciem.

Na zebraniu rolników ekologicznych usłyszałem taką deklarację:

Wygramy, bo ludzie nie dadza sobie wciskać głupot. W końcu wszyscy będa szukać prawdy i prawdziwej żywności.

Żywność produkowana przez ekorolników uznawana jest przez nich za prawdziwa, autentyczna, uczciwa, gdyż powstała na skutek współpracy z Naturą, $\mathrm{z}$ minimalną ingerencją człowieka.

Niektórzy się pytają, dlaczego moje produkty sq takie drogie? Mogę powiedzieć tylko to, że jeśli mówimy o oryginatach, to tylko produkty rolnictwa ekologicznego sa oryginalne, reszta sa to podróbki. Takie jest moje zdanie. Klienci, którzy od kilku lat kupuja, zreszta i ja bym się też nie dat oszukać, gdyby polożyć obok siebie dwa produkty konwencjonalne i ekologiczne, zawsze rozpoznaja. Pierwsze zapach. Nasze po prostu jest oryginalny zapach, jeśli jest to marchewka, pachnie marchewka, a ich marchewki nie maja zapachu. Po drugie smak nasz ma prawdziwy smak, czuć ten smak, a ich smak jest taki jakby się jadto coś z woda, jakby dodano wody. Owszem, ich sq większe, ale można porównać to z herbata, jak się wsypie pare tyżek herbaty do jednej szklanki to będzie mocniejsza, a można ta sama ilość rozsypać na dziesięć szklanek, ale to będzie już zupetnie co innego. Ludzie wyczuleni, jeśli maja sprawny przewód pokarmowy, od razu tak jak ja poczują coś $w$ żotadku, że coś jest nie tak.

$\mathrm{W}$ fragmencie tym eko-rolnik dokonuje utożsamienia płodów ekologicznych zjak ościami autentyczności i oryginalności, a płody konwencjonalne zostały zrównane z podróbkami o niskiej wartości. W dyskursie rolników ekologicznych mamy do czynienia z występowaniem języka moralno-sensualistycznego odmiennego niż abstrakcyjno-techniczny język rolnictwa konwencjonalnego i nauki. Zamiast o jakości życia, mówią o uczciwości, zgodzie z Naturą. Demaskują fałsz logiki estetyki, za którą przemawia świat konsumpcji i przeciwstawiają jej logikę autentyczności i prawdziwego smaku.

Rolnictwo konwencjonalne, wedle eko-rolników to wprost rodzaj oszustwa wobec klientów, często rolnicy ekologiczni przytaczają argument o dwulicowości rolników konwencjonalnych, którzy świadomi szkodliwości chemicznych środków nie 
opryskują pól przeznaczonych do domowej konsumpcji. Wedle relacji jednego z ekorolników:

Chociaż zdarzaja się tacy, co majq chemię na dziesiątkach hektarów, a 20 arów trzymaja bez chemii dla siebie. To jest dla mnie trochę niemoralne, to jest chore. Chociaż sa chrześcijanami, co niedziele ida do komunii, to i tak robia! W sasiedniej wiosce jest gospodarz, 100 hektarów ma, a przed domem ma dziateczkę, 10 arów i tam nie pryska. Dla siebie ma co innego, dla mas też ma co innego.

Widzimy, iż w uczciwości rolników ekologicznych pojawia się silny egalitaryzm, rolnictwo ekologiczne to rodzaj protestu wobec traktowania konsumentów jako ciemnej masy. W wypowiedzi pewnej rolniczki pojawia się stanowczy imperatyw moralny uczciwości w odniesieniu do rolniczej praktyki, nawet jeśli wiązałaby się ona z mniejszymi zarobkami: Taka uczciwość, największa uczciwość powinna być $w$ samym rolniku, (...) bo ekolog to jest taki człowiek, który może biedniej żyć, ale on tam nie popryska, prawda? (podkr. PB). Rolnik ekologiczny jest wiernym swym pryncypiom: nie sprzedaje niczego, czego sam by nie skonsumował. Pryskanie stanowiłoby więc nieuczciwość wobec Przyrody i klientów, których naraża się na uszczerbki w zdrowiu.

Zbigniew Bednarek eko-rolnik z łódzkiego podzielił się ze mną niezwykle cenną myślą:

Nie ma szkoleń z moralności (...) rolnictwa ekologicznego. Nie było. Żadnego. Żeby jakiś ksiądz wyszedt czy jakiś teolog czy etyk i powiedzial, dlaczego nie. To sa szkolenia tylko fachowe, kiedy potrząsnąć gnojem, ile tego gnoju na hektar, jakie bakterie. Na ogót firmy przyjeżdżaja, które chca coś sprzedać i zachwalaja, jakie to rewelacyjne sq efekty stosowania ich preparatu. Powinny być też wykłady z moralności rolnictwa ekologicznego. Dlatego powiedziatem, że brakuje profesora Górnego. Bo to trzeba ludziom wythumaczyć. Wythumaczyć. Bo to musi być jedna catość to dzialanie na polu z etyka. Ale do tego sq potrzebni fachowcy (podkr.PB).

Dobrze oddał on powszechny wśród eko-rolników z misją odczucie, iż szkoleniom w zakresie eko-rolnictwa brakuje podstawowego elementu, jakim jest moralny wymiar działalności, rodzaj etyki zawodowej. Eko-rolnik widziałby w tej roli księdza, teologa, potrzebę szkolenia osób kompetentnych w zakresie moralnego wymiaru rolnictwa ekologicznego. 
W ekologicznym paradygmacie całość życia i poszczególne gatunki mają swoją wartość. Na pielgrzymce rolników ekologicznych do Częstochowy rolnicy ślubowali chronić wszelkie życie u samych jego źródel, nie zabijać owadów, jeśli można tego uniknąć. Ratowanie bioróżnorodności, jedna z głównych wartości światopoglądu ekologicznego, w przypadku rolników znajduje odbicie w modzie na stare odmiany drzew i warzyw, które można odnaleźć w opowieści jednej z pionierek rolnictwa ekologicznego w województwie łódzkim:

Teraz mam plany takie, że chciatam uratować stare odmiany winorośli, sq takie pyszne! Będę rozsadzała sadzonki, jest to roślina bardzo odporna, wspaniate wydaje owoce, dhugowieczna jest, że źródła tego, z którego winorośl odkryłam, ta roślina, nie cięte jest winogrono od 40 lat, ona tak obficie rodzi i jest takie pyszne, że nie chciałam by to zaginęto, chciałabym to rozprzestrzenić, gdzieś tam później innym ludziom dać czy samemu $w$ gospodarstwie. A winorośl, to rolnicy mówią, że rośnie jak chwast (śmiech). Obserwuje to, co potrafi tak rosnać samodzielnie, nie wymaga aż tylu zabiegów. Tak samo orzechy, piękne wielkie drzewa rosna, nawet ci konwencjonalni za bardzo tego nie pryskaja (śmiech), bo to wielkie drzewa rosna $i$ wiesz, to jest taka ekologiczna roślina (śmiech).

Wartością jest ratowanie bioróżnorodności (zachowanie starych odmian) i zgodność z lokalnymi tradycjami upraw. Znamienne, iż pewien eko-rolnik zapytany przez mnie o istotę rolnictwa ekologicznego, zaskoczył mnie swą sensualistyczną wizją:

Znaczy Panu chyba chodzi o pole, jak to wyglada? Jest na pewno inaczej, chwastów widać i inny kolor tych roślin. Jak sq duże goraczki przy upałach wgodzinach poludniowych to u nas te rośliny nie więdna, $u$ konwencjonalnych więdna. Sam krajobraz to u nas wyglada tak naturalnie, a tam tak wymuszono...

We fragmencie tym widzimy wolę zachowania krajobrazu niewymuszonego. Rolnicy ekologiczni dopuszczają występowanie roślin uznawanych za chwasty, uznają uprawę za mały mikrokosmos, gdzie jest miejsce na drzewa, ptactwo, owady, stąd szacunek, jakim darzą bioróżnorodność jest bezpośrednio obserwowalny. 
Dbałość o zwierzęta i humanitarny stosunek do niego to ważny elementem troski o Przyrodę. Oto przykład wypowiedzi jednego z eko-rolników:

\begin{abstract}
Biorąc zdrowotność zwierząt to jest bezporównywalnie lepsza niż $w$ czasach, gdy stosowałem środki chemiczne i nawozy. Szczególnie to widać przy porodach, nie? Bardzo dobra płodność jest niemal stuprocentowa. Jedno zapłodnienie i nie ma problemu. Tak samo krowy, jak i konie nie ma problemu, dobra zdrowotność matych cielaków, źrebaków. Patrząc po zwierzętach sprawdza się, że jak będzie zdrowa ziemia $i$ zdrowe rośliny to będa zdrowe zwierzęta. Wystarczy, że zajrzę do zagrody i spojrzę na moje krowy, one sa takie szczęśliwe, wdzięczne za to, że karmię je zdrowo, że o nie dbam.
\end{abstract}

Szerzej kwestię stosunku rolników ekologicznych do zwierząt omawiam przy okazji analizy poglądów prof. Mieczysława Górnego (podrozdział: Ideologia rolnictwa ekologicznego). Moralne oburzenie względem praktyk karmienia bydła kałem, jak i mówienie w wywiadach o swoich krowach czy krówkach, świniach lub świnkach, a nie o żywcach lub opasach świadczy o moralnym i życzliwym stosunku ekorolników wobec zwierząt. Ekologizacja rolnictwa idzie $\mathrm{w}$ parze $\mathrm{z}$ humanizacją rolnictwa.

Posługując się kategoriami wygenerowanymi przez Krzysztofa Koneckiego (2005) przy badaniach właścicieli zwierząt domowych możemy zaobserwować arenę sporu w przypadku konfrontacji rolnictwa ekologicznego $\mathrm{z}$ konwencjonalnym i wewnątrz świata społecznego rolnictwa ekologicznego: perspektywa antropomorficzna przeciwko perspektywie animalistycznej. Istotą perspektywy animalistycznej jest depersonalizacja zwierząt, właściwe światopoglądowi arystotelejskiemu przekonanie o hierarchii bytów i kartezjańska koncepcja zwierzęcia - maszyny, zwalniająca ludzi z trosk natury etycznej (Konecki ibidem: 23). Perspektywa antropomorficzna zakłada zaś, że zwierzęta podobnie jak ludzie myślą i czują, jej założeniem jest traktowanie zwierząt jak członków rodzin, przypisywanie zwierzętom ludzkich cech. Zwolennicy antropomorficznej wizji zwierząt mogą się opowiadać za ideą równości biocentrycznej, alternatywnej wizji etycznej wobec hierarchii bytów, w ramach której należy dążyć do ochrony każdego życia jako wartości autotelicznej. 
Przykładu antropomorficznej wizji zwierząt dostarcza Zbigniew Przybylak, redaktor Eko Arki - najważniejszego czasopisma eko-rolników. W swym tekście Przybylak (2007d) głosi, iż troski o zwierzęta nie wolno sprowadzić do wymiaru technicznego (np. dbałości o wielkość wybiegu czy jakość pasz), lecz oznacza ona uznanie, iż zwierzę to stworzenie Boże, któremu oprócz godziwych warunków życia należy się szacunek $i$ nawet miłość braterska. Dokonuje on antropomoforfizacji zwierząt pisząc, iż $w$ ujęciu chrześcijańskim, Bożym najważniejszym elementem dobrostanu zwierząt winna stać się milość krów, koni, świń, kur, owiec i serdeczne ich traktowanie na co dzień. Autor przytacza jednocześnie postać patrona ekologów św. Franicszka z Asyżu i staropolski wigilijny zwyczaj dawania krowom kawałka opłatka jako wzoru miłości i wielkiego szacunku dla zwierząt (s. 1).

\subsection{Samowystarczalność}

Ideę samowystarczalności dostarcza charakterystyczna wypowiedź ekorolnika:

$W$ tej rzeczywistości, tak zwanego wolnego rynku, w której żyjemy, tu liczy się tylko pieniądz! Największa role odgrywaja banki $i$ koncerny chemiczne. My nie kupujac ich wyrobów demonstrujemy swoją niezależność i jednocześnie zachowujemy dobre zdrowie.

Samowystarczalność gospodarstwa niekoniecznie jest stanem rzeczy, lecz celem do którego się dąży. Samowystarczalność jest rodzajem niezależności od przemysłu agrochemicznego i banków. Chęć samowystarczalności wynika z właściwej filozofii rolnictwa ekologicznego idei zamkniętego cyklu tak $\mathrm{w}$ zakresie materii organicznej, jak i finansów, gospodarstwo powinno dążyć do samodzielnego utrzymania się, być rodzajem mikrokosmosu, pełnego systemu. Rolnicy ekologiczni z misją uznają, iż system dotacji powinien mieć charakter tymczasowy, służąc rozwojowi rolnictwa ekologicznego w jego wstępnej fazie.

Oto wypowiedź innego eko-rolnika, wskazująca, iż samowystarczalność jest wartością nie tylko w zakresie pojedynczego gospodarstwa rolnego, jak i całego ruchu rolnictwa ekologicznego. Rolnik ten odniósł się do kwestii grantów, jakie dostawał Ekoland od niemieckich fundacji:

Jeżeli mamy coś robić, to róbmy to sami z wlasnych środków jeżeli je mamy, jeżeli chcemy zrobić to będzie miało większy pożytek 
będziemy o to bardziej dbać bo to będzie nasze, wtasne a nie tam powiedzmy czyjeś. Ja uważam, że te pieniądze byty potrzebne w pewnym momencie i powiedzmy dla takiego mtodego ruchu jakieś tam pieniądze z takiej fundacji na pewno przyniosty, jeżeli byly mądrze gospod.. jeżeli byly $w$ madry sposób zagospodarowane to można, to sq potrzebne. Natomiast już dzisiaj kiedy ta struktura istnieje, kiedy rolnicy ekologiczni właściwie maja te doplaty, a więc stać ich na płacenie składek, na placenie jakichś tam, no chociażby podstawowych pieniędzy za, za informację, za gazetke za to za tamto uważam, że nie ma potrzeby tutaj no jakichś tam fundacji, prawda, jakichś środków z zewnatrz bo to, to niczego dobrego dla ruchu nie przyniesie.

\subsection{Wzajemna wspótpraca}

Często się zdarzało, że rolnicy przechodzili wspólnie na ekologię. Oto jeden z przykładów, narracja mazowieckiego rolnika:

Ja tego szukałem dawno, ale nie wiedziatem od czego zaczać. Zorganizowała się koło mnie taka grupa eko-rolników i ja po prostu dotaczytem się do nich, bo miatem dość tej całej chemii i od tego się zaczęto. Zapisatem się no do nich, pojechatem $w 91$ na kurs Ekolandu do Przesieka i trzeba byto czekać na pierwsza kontrolę, druga kontrolę, no i $w 94$ dostatem atest.

Znam dużo przykładów współpracy rolników, jeden wozi z mazowieckiej wsi chleb kolegi do Łodzi, a drugi rewanżuje się mu zabieraniem jego marchewek i kalafiorów do Warszawy. Wreszcie istnieją organizacje takie jak Eko Centrum Zelów, których celem jest wspieranie współpracy rolników, celem tworzenia wspólnej oferty handlowej. Nestor rolnictwa ekologicznego Mieczysław Babalski opowiada, iż:

Jest kilku rolników ekologicznych w naszej okolicy, którzy przy okazji sprzedaży swoich produktów sprzedaja nasz makaron. My odwdzięczamy się im tym samym; $w$ naszym gospodarstwie zawsze mamy zmagazynowane produkty $z$ innych gospodarstw ekologicznych. Mamy od lat statych konsumentów, którym co jakiś czas wysytamy makaron i inne produkty (Soltysiak 1995: 106).

Istotą współpracy jest wzajemność. Niemniej współpraca nie wyklucza łagodnych itwórczych form konkurencji. Jak deklaruje Bogusław Klimczak, długoletni eko-rolnik z łódzkiego: 
z radościa powitam twój produkt koto mojego na pótce sklepowej, będzie to dla mnie inspiracja do tworzenia rzeczy jeszcze lepszych (Soltysiak ibidem :114).

Jest to przykład dynamiki współpracy i przyjaznej konkurencji, która ma być napędem powstających wokół rolnictwa ekologicznego klastrów, takich jak Dolina Ekologicznej Żywności.

\section{Typologia eko-rolników}

Wedle kryteriów administracyjnych rolników ekologicznych można dzielić na certyfikowanych i będących $w$ trakcie procesu certyfikacji ( $w$ pierwszym, drugim czy trzecim roku przestawiania). Podstawą podziału jest przekroczenie formalnego progu zdobycia atestu, będącego jednocześnie przepustką do społecznego świata rolnictwa. Mimo to, podział ze względu na staż nie dotyka czynników świadomościowych, motywacji, tożsamości eko-rolników, itd. Kierując się wizjami zawodu i formami autoprezentacji obecnymi w wywiadach wyróżniłem trzy zasadnicze typy rolników ekologicznych: ekorolnik dotacyjny, ekorolnik z misja (dwa podtypy: pionier i adept) oraz eko-rolnik kontemplacyjny. Poniżej dokonuję charakterystyki wyróżnionych typów.

3.1 Rolnicy dotacyjni

Nie ma wątpliwości, iż spowodowany korzystnymi warunkami instytucjonalnymi niezmiernie gwałtowny wzrost liczby gospodarstw miał charakter chaotyczny i wielu rolników dało się skusić dotacjom, nie mając świadomości złożonego charakteru gospodarowania ekologicznego. Eko-rolnicy z którymi prowadziłem wywiady często przytaczali znamienny przykład rolników z Marszałkowskiej czyli cwanych wielkomiejskich biznesmenów, którzy kupili ziemie, najczęściej łąki i pozorując uprawy ekologiczne otrzymało dopłaty. Oto jak wygląda fenomen rolników dotacyjnych $\mathrm{w}$ perspektywie rolnika $\mathrm{z}$ Mazowsza $\mathrm{z}$ 12-letnim doświadczeniem:

Gospodarstw jest $w$ tej chwili może z 5 tysięcy, a tych, co produkuja na rynek, dla ludności do spożycia jest niewielu tych ekologów mniej niż tysiacc, pięciuset. Sa tacy ekolodzy tylko do dotacji. Nie ma 
dużo ekologów, którzy by towar dostarczali na rynek, sa tacy, którzy mają tysiąc hektarów tąk i biorq dopłaty, tacy, którym cała ta ekologia.. to chodzi im tylko o pieniądze, a nie jakaśs ideę ekologiczna.

Osobiście udało mi się dotrzeć do dwóch rolników, którzy nie ukrywali, iż nie interesowali się zbytnio ekologią, a do decyzji o ekologicznej konwersji skłoniły ich same dopłaty. Rolnicy owi zajmowali się niemal wyłącznie wypasem bydła i liczyli, że również pod względem pracochłonności ekorolnictwo okaże się korzystniejsze. Oto fragment mojej rozmowy $\mathrm{z}$ rolnikiem $\mathrm{z}$ woj. zachodniopomorskiego z 12-letnim stażem w rolnictwie konwencjonalnym, który obecnie jest w drugim roku przestawiania na metody ekologiczne:

B. Prositbym by mi Pan opowiedziat, jak to się stało, że został Pan rolnikiem ekologicznym.

R. Przede wszystkim pieniądze, tak, dopłaty. Znaczna suma nie taka zła, no. A, że koszty produkcji się zmniejszają, no bo nie ma nawożenia, nie? Nie ma nawożenia, sq dopłaty. Hektarów mamy $w$ miarę dużo. Uznatem, że warto po prostu.

B. I Pan Marian [rolnik ekologiczny z wieloletnim stażem z tej samej wsi-B.] Pana namówit?

$R$. To znaczy no... rozmawiatem trochę z Marianem. On caty czas, nawet wcześniej mi proponowat, nawet wcześniej gadat: no na to przejdź! Kiedyś były mniejsze, znacznie mniejsze dopłaty, po prostu nie było sensu, nie było opłacalności żeby na to przechodzić, a teraz uznatem, że warto.

B. Tak z czystych takich praktycznych względów?

R. Raczej tylko i wytacznie z czysto praktycznych! Żadnej ideologii $w$ tym nie ma (śmiech).

B. Czy więcej ma Pan teraz roboty, mniej czy tyle samo?

R. Mniej. Mniej. Uważam, że mniej, bo nie mam tych zabiegów, nawożenia, oprysków nie ma...

B. A jakie ma Pan dalsze pomysty na rozwój gospodarstwa?

$R$. Nic, kontynuować, nic innego na razie nie wymyślam.

B. Zapisywat się Pan do jakichś stowarzyszeń rolników ekologicznych?

R. Nie, nie, nigdzie sie nie zapisywatem. (...) Myślałem wprawdzie o tym orzechu włoskim, prawdę mówiąc trochę, tam wypadało by się zapisać, bo przetwórstwo tego orzecha wspólne...

B. Takie drzewko niewiele opieki wymagajace, prawda?

R. Nie dużo opieki, a sa dosyć duże dopłaty. Jak będzie przetwórstwo to jeszcze będa pieniądze z tych owoców, orzechów.

$B$. Brat Pan udział $w$ jakichś kursach rolnictwa ekologicznego?

R. Nie. Nie.

B. A bytby Pan zainteresowany, gdyby się pojawity takie kursy?

R. To znaczy (milczenie -PB.) coś bym postuchat. Może bym się dowiedział czegoś ciekawszego, nowego. 
W przytoczonym powyżej fragmencie wywiadu znalazłem potwierdzenie, iż faktycznie istnieją rolnicy dotacyjni. Mój rozmówca otwarcie przyznał, iż wyłącznie atrakcyjność finansowa dotacji skłoniła go do konwersji. Odcinając się od ideologii, wykazywał brak zainteresowania szerszym, filozoficznym aspektem rolnictwa ekologicznego. Nie ukrywał, iż aspirował głównie do spokojnego życia, nie był zainteresowany rozwojem działalności przetwórczej, cieszył się, iż ma mniej roboty przy krowach, zaintrygował go orzech włoski jako wybitnie wygodna uprawa. Nie zamykał się na nowości techniczne, deklarował gotowość uczestnictwa w bliżej nieokreślonych kursach, lecz nie miał ku temu silnej potrzeby. Z jego opowieści wyłania się opcja na stagnację: byle przetrwać, dostać dotacje i się nie narobić. Zdaniem doświadczonych rolników, część z rolników dotacyjnych będzie musiała przystosować się do filozofii gospodarowania ekologicznego i dzięki temu wytrwa, a część powróci do rolnictwa konwencjonalnego:

$Z$ tym, że tak jak mówię panu, sa to gospodarstwa, które powstaty nie na wskutek, że tak powiem zamitowania do rolnictwa ekologicznego tylko na wskutek warunków ekonomicznych jakie stworzyło państwo a więc dofinansowań. Przyszłość tych gospodarstw może być różna uważam, że na pewno kilka z nich powróci do starych metod konwencjonalnych, natomiast na pewno $50 \%$ z nich pozostanie $w$ tym, i być może też zrobi coś ciekawego $w$ tym temacie. To jest taka naturalna selekcja, ludzie przychodza i odchodza, jak wszędzie, tak samo od rolnictwa.

3.2 Eko- rolnicy z misja

To jest zawód z misją, no zawód z misja, produkcja zdrowej żywności dającej ludziom site $i$ zdrowie. To nie jest żywność przemystowa, która ludzi truje i napędza kiese lekarzom. Żywność to jest medium, to coś z czego buduje pan wtasne ciało. Co pan będzie jadt, taki będzie. Tworzymy lepsze spoleczeństwo przez zdrowsza żywność. Takie to pozytywistyczne, prawda? (śmiech)

W moich badaniach dotarłem również do odmiennych przykładów rolników, którzy choć wymieniają dotacje jako główny czynnik brany pod uwage przy wyborze ekologii, to oni podjęli dojrzałą decyzję, świadomi wielu konsekwencji, z chęcią dokształcają się w zakresie technik rolnictwa ekologicznego i czerpią satysfakcję z produkcji zdrowszej żywności. Zawód z misją to kategoria powstała na podstawie narracji cytowanego powyżej łódzkiego eko-rolnika, który wspomniał o misji, po czym zreflektował, iż brzmi to pozytywistycznie. Kategoria ta odsyła do całej gamy 
zagadnień moralnych, które omawiam następnie w podrozdziale: Wartości rolnictwa ekologicznego. To dla eko-rolników z misją ważna jest praktyczna realizacja owych wartości.

Jedynie eko-rolnicy z misją budują swą tożsamość w oparciu o profesję, gdyż rolnicy dotacyjni nie uczestniczą $\mathrm{w}$ organizacjach rolników ekologicznych, nie posiadają znajomości filozofii eko-rolnictwa, czują się trochę nieswojo jako ekologiczni, a kontemplacyjni, choć są przekonani do idei ekologicznych, posiadają ważniejsze od rolnictwa źródła tożsamości.

Eko-rolnicy z misją stanowią, można by rzec, najbardziej dojrzały typ rolników ekologicznych, to właściwie ich trajektoria została przedstawiona w podrozdziale Proces stawania się rolnikiem ekologicznym, jak i w studiach przypadku organizacji Ekoland i Eko-Centrum Zelów i wizji jej prezesa - Zbigniewa Bednarka. Eko-rolnicy z misją to rolnicy, którzy godzą ekologiczne powołanie z koniecznością zarabiana na utrzymanie własnej rodziny. Chętnie promują zdrową żywność i idee rolnictwa ekologiczne wśród sąsiadów czy za pomocą prelekcji w szkołach czy publicznych zebrań. Jednocześnie mają świadomość wspólnoty interesów: namawiając innych rolników do konwersji na ekologię, pomagają zarówno sprawie, jak i sobie, gdyż przyczyniają się do rozwoju rynku rolnictwa ekologicznego.

Wśród eko-rolników z misją możemy wyróżnić pionierów i adeptów. Pionierzy są skupieni głównie w stowarzyszeniu Ekoland i przecierali szlaki na początku lat 90ych, kiedy ich Stowarzyszenie zajmowało się certyfikacją produkcji ekologicznej, a reguły i normy były dopiero ustalane. Nie istniał również rynek żywności ekologicznej, pionierzy musieli tworzyć go od postaw, jeżdżąc do Warszawy i dużych miast. Eko-rolnicy z misją - adepci darzą szacunkiem pionierów i odczuwają z nimi wspólnotę ideałów, uznają rolnictwo ekologiczne nie tylko za zawód, ale za misję, sposób na życie.

\subsection{Eko-rolnicy kontemplacyjni}

Certyfikowane gospodarstwa ekologiczne posiadają nie tylko rodziny czy samotni rolnicy i rolniczki, lecz również organizacje, dla których funkcja produkcyjna gospodarstwa ma znaczenie drugorzędne. Istotne są dla nich sam proces pracy i kontakt z naturą. Zdrowa żywność jest dla nich wartością, lecz posiadają inne źródła utrzymania i tożsamość rolnicza jest dla nich tożsamością poboczną. W przypadku 
Fundacji Barka położone na obszarze Wielkopolski gospodarstwo ekologiczne pełni funkcje resocjalizacyjną dla osób uzależnionych, bezdomnych, autorzy projektu wskazują na terapeutyczna funkcję pracy na roli. Dotarłem też do przykładu pochodzącego z miasta rolnika ekologicznego, z przekonania wegetarianina i ekologa, posiadającego kilka hektarów ziemi i stadninę koni huculskich. Posiadał on pewien sad, drobne uprawy warzywne, lecz nie produkował żywności na potrzeby rynku, gdyż uprawa miała dla niego charakter kontemplatywny, w ten sposób doświadczał udziału w cyklach przyrody, relaksował się. Posiadał inne źródło utrzymania niezwiązane $\mathrm{z}$ rolnictwem.

Także organizacje o charakterze religijnym posiadają gospodarstwa ekologiczne. Ognisko Miłości, wspólnota rzymskokatolicka, prowadzi dom rekolekcyjny w Olszy w gminie Rogów (woj. łódzkie), który został nabyty wraz z 10 hektarami sadu. Wspólnota obejmuje księdza i kilkoro świeckich uczestników, którzy nie określają siebie jako rolników. Najważniejszym działaniem, czyli wedle kategorii mej rozmówczyni charyzmatem, jest prowadzenie rekolekcji. Oto fragment narracji jednej z członkiń wspólnoty, która porzuciła duże miasto i na stałe osiedliła się w domu rekolekcyjnym pod Rogowem:

To jest tak, że kupując ten teren dostaliśmy sad, on byt normalnie pryskany, prowadzony owocowo, byt źródłem dochodu. Nas za to rolnictwo nie interesowato samo $w$ sobie, kupiliśmy to dla domu, dla terenu, a nie dla sadu. Ale szybko się okazało, że szkoda, że po pierwsze to szkoda, żeby taki sad się zmarnowat. Na początku pryskaliśmy, przycinaliśmy. Tak naprawdę od sq̨siadów uczyliśmy się miłości do ziemi. Zaczęliśmy dbać o ten teren, że jeden z sąsiadów nam pomaga, tak rolniczo. Nie mamy zamiaru, żeby byt on źródtem dochodu, to też nie, ale fajnie mieć swoje owoce $i$ wtedy dobrze zadbać by byly zdrowe. Też ze względu na to, że sad nie jest miejscem naszej inwestycji i tak to powoli odchodzi się od konwencjonalnych metod. Później nam doradzili $w$ Agencji Restrukturyzacji i Modernizacji Rolnictwa byśmy przestawili się na ekologię. (...)

Światopoglądowo to jest trudno nazwać nas rolnikami ekologicznymi, my tym nie handlujemy, to co jest robimy na nasze potrzeby, nie ma $w$ tym głębokiej ideologii, poza tym, że jak mamy już owoce dla nas i ludzi, których przyjmujemy, to dobrze by byto to zdrowe. $Z$ tym, że ja myślę, że chrześcijaństwo samo w sobie jest ekologiczne, chodzi o życie $\boldsymbol{w}$ zgodzie z natura (podkr. $P B)$.

Otóż, podstawowe działanie eko-rolników: produkcja żywności ekologicznej, nie była głównym celem. Wspólnota stała się właścicielem sadu niejako z przypadku. 
Niemniej, doszło do procesu do dopasowania rolnictwa ekologicznego do światopoglądu katolickiego, w ramach idei życia $w$ zgodzie z natura. Z tym, że uprawa ekologiczna ciągle jest działaniem podrzędnym wobec rekolekcji i praktyk duchowych.

Znamienne, że w narracji tej pojawia się wartość miłości do ziemi, która w procesie badawczym okazała się być centralną wartością rolnictwa ekologicznego. Choć moja rozmówczyni nie uczestniczyła w środowisku rolników ekologicznych, nie znała podstawowego czasopisma eko-rolników Eko Arki, można mówić o znacznej wspólnocie światopoglądowej jej poglądów i rolników ekologicznych.

Innego przykładu organizacji o charakterze religijnym prowadzącej gospodarstwa ekologiczne jest Ananda Marga (AM), organizacja formalnie mająca charakter organizacji pozarządowej, lecz w praktyce promującą ścieżkę duchowego doskonalenia i pewną metafizyczną wizję kosmicznej jedności całego stworzenia i idee neohumanizmu. Ananda Marga jest pochodzącym z Indii międzynarodowym Stowarzyszeniem zainspirowane ideami hinduskiego filozofa P.R. Sarkara, liczącym wedle własnych deklaracji blisko milion członków w 160 krajach (www.anandamarga.pl). W Polsce ów ruch posiada dwa, liczące kilkanaście hektarów, gospodarstwa, jedno w Głębocku (woj. dolnośląskie), drugie w Giżach (woj. warmińsko - mazurskie). Miałem okazję prowadzić obserwację uczestniczącą w Głębocku w trakcie organizowanego przez Anandę Margę Festiwalu Ekologii Neohumanistycznej (lipiec 2006). Jeden z przedstawicieli ruchu, Dada Maheshvarananda, następująco tłumaczył mi filozofię swej organizacji:

Opowiadam się za ekologia neohumanistyczna jako alternatywna wizją lepszego świata, połaczeniem alternatywnego systemu gospodarczego i promocji holistycznego stylu życia, który jednostki moga przyjać celem wywierania lepszego wptywu na planetę. Holistyczny styl życia zakłada redukcję konsumpcji dóbr materialnych, diete wegetariańska, ekologiczna produkcje żywności, postawę zorientowana duchowo (spiritual outlook), jak i również etykę aby uzyskać holistyczny, zrozumiaty ogląd planety. $W$ perspektywie społecznej proponujemy spótdzielnie jako podstawę gospodarczej demokracji $i$ zachęcamy ludzi aby chronili środowisko na całym świecie. Neohumanistyczna ekologia oznacza akceptacje wszystkich ludzi, zwierząt, roślin i skat w jednej ludzkiej rodzinie.

Zapytany o znaczenie rolnictwa ekologicznego, odpowiedział mi, iż jest to sprzyjajacy medytacji i postępowi ludzkości ważny element neohumanizmu. 
Chociaż Ananda Marga w niewielkim zakresie prowadzi sprzedaż produktów ekologicznych, to rolnictwo ekologiczne ma charakter dodatkowej działalności, wpisującej się w realizację szerszej wizji społeczno-duchowej. Uznaję ich za ekorolników kontemplacyjnych, gdyż członkowie ruchu nie budują swej tożsamości w oparciu o rolnictwo ekologiczne. Gospodarstwa AM nadzorują mnisi zwani dada (sanskryt: brat) i mniszki zwane didi (sanskryt: siostra) zawsze ubrani na pomarańczowo, kolor mający symbolizować oddanie dla ludzkości i dążenie do wyzwolenia. Doświadczeni polscy eko-rolnicy kojarzą ów ruch, gdyż dada pojawiał się na imprezach związanych $\mathrm{z}$ ruchem, takich jak dożynki w Przysieku i cieszy się akceptacją .

Między eko-rolnikami kontemplacyjnymi a eko-rolnikami z misją nie występują znaczące różnice w zakresie wartości, lecz różni ich praktyczny stosunek do podstawowego działania, jakim jest wytwarzanie żywności ekologicznej. Dla ekorolników z misją owe działanie jest istotą sposobu życia, powołaniem, ale i równocześnie ważnym źródłem utrzymania. Dla eko-rolników kontemplacyjnych z kolei jest to działanie dodatkowe, jednocześnie zgodne z ich poglądami, lecz nie mające kluczowego wpływu na definicje ich tożsamości.

\section{Proces stawania się rolnikiem ekologicznym}

W przejściu na ekorolnictwo ważne są motywy konwersji, czyli radykalnego zerwania z dotychczasową praktyką rolnictwa konwencjonalnego i przyjęcia zupełnie odmiennej ekologicznej praktyki. Zazwyczaj moi rozmówcy odziedziczyli gospodarstwa ekologiczne po rodzicach i skończyli studia rolnicze lub technikum rolnicze i zdobyli odpowiednie kwalifikacje do prowadzenia gospodarstwa chemizowanego. Rolnicy ekologiczni są ogólnie lepiej wykształceni niż zwykli rolnicy. Wszyscy moi rozmówcy skończyli przynajmniej zawodową szkołę rolniczą, najliczniejsza grupa technikum rolnicze, a i nie brak wśród nich absolwentów wyższych studiów rolniczych. Wedle cytowanych przez Mieczysława Górnego (1997) badań S.Grykień z 1996 roku, kiedy istniała jedynie grupa ponad 200 pionierów ekorolnictwa, można było zauważyć, iż aż 21\% ekorolników miało wykształcenie wyższe, a 47\% średnie, podczas gdy wskaźniki wykształcenia dla ogółu rolników wynosiły odpowiednio 1\% i 8\% (s. 3). Tak kontrastujące dane uprawniałyby tezę, iż rolnicy ekologiczni stanowili część wykształconej elity rolnictwa. 
Badani przeze mnie eko-rolnicy $\mathrm{w}$ większości pochodzili ze wsi i $\mathrm{w}$ toku socjalizacji pierwotnej zostali zapoznani z charakterem pracy rolniczej. Tylko nieliczni pochodzili z miasta i zostali rolnikami konwencjonalnymi, realizując dziecięce marzenie o życiu na wsi, wskutek np. otrzymania gospodarstwa w spadku. Każda opowiedziana mi przez eko-rolników historia miała swój unikalny charakter. Droga jednej rolniczki do ekologii wiodła przez decyzje o przejściu na wegetarianizm i uczestnictwo w ruchu wegetariańskim. Inna pochodząca z miasta rozmówczyni była nauczycielką biologii, która zafascynowała się ekologią i jako dojrzała kobieta i wskutek nauki ekologii poczuła, iż jej drogą jest rolnictwo ekologiczne, które koresponduje z jej dziecięcym marzeniem o mieszkaniu na wsi. Mając na względzie świadomość celu, zajęła się przez pewien czas zarabianiem pieniędzy w branży reklamowej by zarobić na kupno niewielkiego, podupadłego gospodarstwa i rozpocząć realizację owego marzenia. Jest to przykład niezwykłej determinacji kobiety w spełnianiu własnych marzeń. Pragnę w jak największym zakresie dać świadectwo różnorodności świata społecznego i dlatego nie chcę przykrajać świata na potrzeby schematu, pomijając znaczące odmienne przypadki lub unieszkodliwiać je potoczną formułą wyjątku potwierdzającego regułę. Niemniej, mogę pokazać jak wygląda najbardziej typowa droga, dając do zrozumienia, iż w naszym złożonym świecie możliwych jest więcej dróg.

Nie tylko każda trajektoria stawania się rolnikiem ma swoją wyjątkową specyfikę, lecz na dodatek mamy do czynienia z historiami otwartymi współcześnie żyjących ludzi, którzy budują legendę profesji cieszącej się ledwie 20-letnią historią. W dodatku warto uwzględnić, iż jest to historia tocząca się niezwykle dynamicznie (fenomen 5o-krotnego wzrostu liczby rolników w ciągu ostatnich 10 lat i 2,5-krotnego w ciagu ostatnich 3 lat, zmiany instytucjonalne spowodowane przez wstąpienie do Unii Europejskiej). Stąd zastrzegam, że najbliższa przyszłość może przynieść wypracowanie nowych praktyk, wymagających istotnych korekt niniejszego schematu.

Mając na uwadze powyższe zastrzeżenia, mogę zaproponować pewien schemat ważnych etapów drogi ku rolnictwu ekologicznemu, które pojawiły się w przynajmniej kilku historiach. Typowa historia zaczynała się słowami: Gospodarstwo przejątem po rodzicach $w$ '76 roku. Konwencjonalne. To znaczy wtedy było na rodziców, zaczątem pracować z rodzicami $w$ '76, a $w$ ‘8o roku zostato przepisane na mnie. Czyli punkt startu jest w momencie, gdy nasz bohater jest już rolnikiem lub rolniczką 
i tak jak wszyscy znani mu rolnicy, stosuje syntetyczne nawozy i środki ochrony roślin, zwane potocznie chemią. Jak zastrzegłem na wstępie, jest osobą lepiej wykształconą niż przeciętny rolnik, mając za sobą skończone technikum rolne lub rolniczą akademię. Oto jak dalej rozwijać się będzie opowieść o bohaterze, każdy ze wskazanych etapów poddam analizie w osobnym podrozdziale:

Etap I "Zarażenie się":

Prowadzenie gospodarstwa konwencjonalnego -> zmęczenie chemiq -punkt zwrotny -> przypadkowy pierwszy impuls -> osobista przygoda - poznanie znaczących innych - eko-rolników i ekspertów -> decyzja o konwersji

Etap II "Nauka":

Obserwacja innych i pobieranie nauki - > bariery: niskie plony i drwiny ze strony pierwotnej grupy odniesienia i znaczących innych->

Etap III "Dojrzałość":

Poszukiwanie własnej formuły gospodarstwa (profesjonalizacja, oswojenie rynku) -> zdobycie uznania pierwotnej grupy odniesienia - > znalezienie punktu optimum

4.1 Zmęczenie chemiq - punkt zwrotny

W historiach konwersji, najczęściej na wstępie pojawia się moment dojścia do punktu zwrotnego, w którym czuje się absurdalność stosowania chemii, wewnętrzny dysonans, który wyrażają te słowa: za każdym razem jak pryskatem, coś tak czutem, że krzywdzę ziemię. Oto jak pewien rolnik ekologiczny z łódzkiego tłumaczył mi swą decyzję:

Ja miatem jakiś taki podskórny wstręt do tej chemii. Zawsze jak zabieratem się do tego pryskania, to czulem, że coś zlego robitem. Dopóki nie przeczytatem o Ekolandzie $i$ kursach rolnictwa ekologicznego $w$ Przysieku, to nie wiedziatem za bardzo dlaczego, ale miałem takq intuicję. Dziś, choć żona pracuje poza gospodarstwem i mamy niskie doptaty, za nic nie wrócilbym do chemii. 
Inny eko-rolnik wskazuje również na intuicyjną niechęć do środków chemicznych, która dopiero po poznaniu rolnictwa ekologiczna uległa racjonalizacji. W jego nieświadomej niechęci jakby brzmiało echo późniejszego przeznaczenia:

Czułem się źle, stosując te nawozy, czutem niechęć do nawozów sztucznych, niechęć wewnętrzna do środków chemicznych. Nie wiem skad się ta niechęć brała, nie byłem przeszkolony, że jest to szkodliwe, ale czutem, że coś mi nie pasowata, nie było $w$ rodzinie problemów ze zdrowiem, ale wewnętrzna niechęć była.

Idiosynkrazja, jaką rolnicy ekologiczny darzą preparaty nieorganiczne, zwane powszechnie chemiq wydaje się być koniecznym elementem ich credo i początkiem przemiany. Pewien eko-rolnik wskazuje, iż to intensywna urzędowa promocja nawozów sztucznych odniosła odwrotny efekt:

Tej chemii to było wtedy za dużo, nie tylko mnie to przeszkadzało, wtedy to byly nakazy z urzędu gminy stosowania określonej ilości nawozów, środków chemicznych, na polach robity się tak zwane przepłony - mniejsze rośliny albo $w$ ogóle nie rosły. Także gdybym poszedl $w$ kierunku chemizacji to po paru latach ta ziemia przestałaby rodzić $w$ ogóle. A po kilku latach ekologii wszystko się wyrównato, także (...) teraz jest dobrze.

Nie wszyscy jednak od początku podskórnie czuli, że z chemią było coś nie tak. Mamy do czynienia również z barwnymi historiami całkowitej przemiany. Pewna rolniczka miała tak silną wiarę $\mathrm{w}$ rolnictwo technologiczne, że skończyła studia chemiczne by z dużym zapałem zabrać się za chemizację gospodarstwa. W narracji innego eko-rolnika pojawia się radykalizm w stosowaniu środków chemicznych, aby całkiem z nich zrezygnować:

Skończytem tak na przełomie tych lat 80 studia rolnicze, żeby pogłębić wiedze i miałem ambicje wtedy by schemizować cate gospodarstwo $w$ stu procentach, no bo tam się dowiedziatem nowej wiedzy. Studia skończyłem chyba $w$ stanie wojennym albo tuż przed stanem wojennym, jakoś $w$ 81, może 82 (...) i potem $w 84$ zetknąem się z ta idea gospodarstwa ekologicznego, z gazety i śledzitem potem wszystkie te informacje $i w 86$ zdecydowatem się przejść na rolnictwo ekologiczne po tam tych tam różnych takich, niezbyt jakby to powiedzieć, niezbyt przekonywujacych doświadczeniach $z$ chemia. Bo wtedy, $w$ tym momencie, gdy staratem sie schemizować wszystko na maxa, żeby palcem nie ruszyć by chwast wyrwać, bo wszędzie byly herbicydy, doszedtem do wniosku, że dochodzę do absurdu i ta idea spodobała mi się (podkreślenia - PB). 
Dwa lata się nad niq // przyglądatem się jej, bo to byty tylko szczątkowe informacje. Udało mi się pierwszy raz w jakimś kursie uczestniczyć ekologicznym...

Badani przeze mnie rolnicy znajdowali się najczęściej w sytuacji kryzysu, na który mogły się składać złe plony, choroba dziecka lub małżonka, związana z utratą wiary w skuteczność środków chemicznych i przekonanie, iż lekarstwem na niedomagania chemii jest więcej chemii. Instytucje rolnicze znały tylko jedną konwencjonalną drogę, którą Mieczysław Górny (2002) przedstawia na zawartej w swej książce karykaturze, gdzie doradca rolniczy mówi do słuchawki telefonicznej: Najpierw zastosować nawóz, potem będziemy dyskutować (s. 90). Niemniej, słabe plony przekładały się na kiepską sytuację ekonomiczną, czasami rolnicy byli zmuszeni do sięgnięcia po kredyt. Pomimo to, rolnicy nie znali jeszcze alternatywnej drogi, ale mieli poczucie, iż chętnie zdecydują się na radykalną odmianę, wyruszając na własne poszukiwania.

\subsection{Przypadkowy pierwszy impuls}

Rolnik wątpiący w sens swej dotychczasowej drogi był otwarty na sygnały płynące ze świata, wprowadzenie innowacji umożliwiającej inny sposób gospodarowania. $\mathrm{W}$ owym momencie kluczowe znaczenia miała zwykła informacja o kursach rolnictwa ekologicznego, organizacjach eko-rolniczych. W tej sytuacji w grę wchodził przypadek, który zadecydował o punkcie zwrotnym w ich życiu, informacja $\mathrm{w}$ gazecie rolniczej o kursie rolnictwa ekologicznego, a w pewnym przypadku informacja o Ekolandzie w piśmie kobiecym. Z pomocą rolnikom wychodziły Ośrodki Doradztwa Rolniczego, które w latach 90 po zinstytucjonalizowaniu Ekolandu zwykły organizować otwarte wykłady czołowych postaci polskiego rolnictwa ekologicznego. Czasami z pomocą przychodzili inni rolnicy, znajomi naszego bohatera, którzy przekazywali informacje o takich wydarzeniach.

4.3 "Osobista przygoda" (poznanie znaczqcych innych)

Zdaniem T. Shibutaniego, w konwersjach religijno-ideologicznych kluczową rolę odgrywają znaczący inni, czyli nowa grupa odniesienia, która zdobywa hegemonię $\mathrm{w}$ oddziaływaniu na proces określania tożsamości jednostki. Także 
w przypadku decyzji o przejściu na ekologię, rola charyzmatycznych liderów i autorytetów - najczęściej naukowców lub rolników z wieloletnim doświadczeniem i autentycznym zapałem okazuje się być ogromna. Pewien łódzki rolnik mówi wprost o charyzmie prof. Górnego, jako czynniku, który wpłynął na jego decyzje o konwersji:

A taka moja osobista przygoda to było.. troche sie tym interesowatem $i$ przypadkiem trafitem na spotkanie $w$ ODRze $w$ Kościelcu, wystapienie prof. SGGW Mieczysława Górnego, kto się zna na rolnictwie ekologicznym to wie - była to historia, on właśnie thumaczyt mechanizmy, że tu $w$ rolnictwie konwencjonalnym praktycznie pracujemy na koncerny chemiczne, bo oni raz sprzedaja nawozy, środki $i$ doprowadzaja do tego, że ta żywność jest jej dużo, jej więcej może, ale jest nieodporna, stałe zagrożenia szkodnikami, potrzeba nadużywania nawozów i środków, te rośliny sa nieodporne, za tym idzie zdrowie zwierząt $i$ ludzi. Żeby doprowadzić do zdrowia ludzi, trzeba mieć zdrowa ziemie, potem zdrowe rośliny $i$ zdrowe zwierzęta by było zdrowe żarcie $i$ dopiero będa zdrowi ludzie. A jak będziemy jedli byle co, ale tadnie opakowane to niestety. (podkr. PB.)

Mieczysław Babalski, jeden z pionierów rolnictwa ekologicznego i właściciel wytwórni makaronów razowych, był dla pewnego zachodniopomorskiego rolnika ekologicznego i twórcy wytwórni serów głównym znaczącym innym - inspiratorem przejścia na metody uprawy ekologicznej i rozpoczęcia przetwórstwa:

Jesienia, tego samego roku bytem na takim pierwszym spotkaniu organizowanym przez ODR, tutaj Koszalin, na którym poznatem Miecia Babalskiego. I właściwie te jego (yy) to o czym on mówit dla mnie było bardzo interesujace. Stuchatem go, że tak powiem, z otwarta buzią. to wszystko co, o czym on mówit, zaczęto mi pasować do mojej rzeczywistości, do moich problemów, które mi się zrodzity a więc to zadtużenie, prawda, ten ten ten ta sytuacja, że tak powiem taka, no że tak powiedzmy, krytyczna gospodarstwa i myślę sobie: ten człowiek ma dużo racji.

W tym wypadku Babalski umożliwił ekologiczną inicjację owego rolnika, dostarczył mu narracji i kategorii opisujących problemy, jakich doświadczał. Doszło do dopasowania proponowanej teorii i życiowej praktyki. W momentach inspiracji osoba propagująca rolnictwo ekologiczne musiała mówić rzeczy nowatorskie, zaskakujące, ale równocześnie zrozumiałe, stanowiące klucz interpretacyjny dotychczasowych, fragmentarycznych, teoretycznie nieogarniętych, doświadczeń rolnika - nieskuteczności środków ochrony roślin, klęski suszy, bankructwa 
i rosnącego zadłużenia. Babalski zaproponował mu przekonującą narrację o strategii przemysłu agrochemicznego i zaproponował drogę wyjścia z sytuacji kryzysowej. Sam Babalski, który w 1985 zaczął uprawiać ekologicznie również przeżywał wcześniej momenty głębokiej inspiracji. W biograficznym artykule wskazuje na kluczową role inspiracji płynącej ze strony pioniera biodynamiki - Juliana Osetka, prof. Mieczysława Górnego i niemieckich nauczycieli biodynamiki:

Dopiero pierwsze spotkanie $w 1983$ roku $z$ rolnictwem alternatywnym - wykład inż. Juliana Osetka $w$ Książnicy koło Torunia o metodzie biodynamicznej - dało mi dużo do myślenia. Później korzystałem z różnych dostępnych mi publikacji oraz kursów, na których wykładowcami byli prof. Mieczysław Górny, Maria Thun i dr Christian von Wistinghausen (Sottysiak 1995: 103107).

W wielu wywiadach znajdywałem potwierdzenie, iż na polskim gruncie dwoma najwybitniejszymi propagatorami rolnictwa ekologicznego byli prof. Mieczysław Górny z SGGW i rolnik Julian Osetek. Pewien łódzki rolnik relacjonując historię swej konwersji, z duża estymą wspomina postać Górnego: profesor Górny nieżyjący już $w$ tym roku zmarl, $w$ tamtym roku, nestor polskiego rolnictwa, organizator polskiego rolnictwa - on organizowal kurs, on przemawiat... Inna rolniczka wspomina zaś:

Teraz to odszed ten Górny, Mieczystaw Górny, on to ze świata nauki jako pierwszy popart tych rolników. Ciekawy byt ten "Ekoland" na poczatku, bo byli rolnicy i naukowcy, uczelni pracownicy jak pani Sottysiak, która ma teraz tą firmę Agro Bio Test, ona ciagle pracuje na uczelni. To byly bardzo fajne spotkania, naukowcy to nam od strony nauki to wszystko, rolnicy od strony praktyki, bardzo bylo ciekawie, jak profesor Górny żyl, bo on to wogóle był taki specyficzny, był krytykowany, szydzony przez kolegów, że się takimi bzdurami zajmuje, a on nigdy nie zdradził tej ekologii, bronit rolników i to jest jakby taki zatożyciel Ekolandu.

Prof. Górny jest ikoną polskiego rolnictwa, a we wspomnieniach takich, jak powyższe przypisuje się mu godny podziwu nonkonformizm, odwagę do bronienia prawdy będącej w posiadaniu mniejszościowej grupy, co narażało go na konflikt z naukowym establishmentem, stojącym na straży starego paradygmatu. Nie zetknąłem się z żadną krytyczną opinią wobec jego poglądów i działań.

Profesor Górny potrafil, jak wynika ze wspomnień, zaproponować przekonująca i urzekającą narrację, w prosty sposób wyttumaczyć rolnikom coś, co 
można by nazwać "ekonomią polityczną rolnictwa". W relacjach pojawia się również motyw jego skromności i umiejętności rozmawiania ze zwykłymi ludźmi, jak równy z równym. Potwierdził ową tendencje sam Górny w udzielonym na miesiąc przed śmiercią wywiadzie: Ucieszyłem się, gdy przeszedtem na emeryturę, bo mogłem wreszcie zaczać pisać dla ludzi normalnym prostym językiem bez konieczności używania wielu terminów naukowych (Eko Arka 3/2005: 32-33).

Rolnicy ekologiczni często mają świadomość misji swego rolnictwa. Przywiązują wielką wagę do uczciwości, a o produkcji żywności mówią, podobnie jak Górny, w kategoriach moralnych, oto relacja jednego z badanych rolników:

Dzisiaj robiąc to, co robię mam petna świadomość tego, że produkuję żywność, która sam jem i która chętnie, mogę - polecam innym. A więc mam spokojne sumienie, ze robiac to, co robie nie narażam ludzi na jakieś przykrości, na jakieś (yyy) no nie wiem choroby, dolegliwości, prawda (podkreślenia - PB.). Nie potrafitbym dzisiaj robić żywności konwencjonalnej, prawda? Wprowadzać tam jakichś dodatków zastępczych, uzupetniających, poprawiajacych smak, poprawiajacych trwatość $i$ tak dalej, bo uważam, ze to jest wszystko nieszczęście XX wieku. Że to jest nieszczęście ówczesnej cywilizacji, robienie czegoś takiego właśnie. Ija to czuję, czuję to na własnym, czuję to na sobie, czuję to na, widzę to po swoich dzieciach, jak one rosna jak one się rozwijaja, prawda? I też je odsuwam często od chipsów, od McDonalda od Pepsi Coli. Bo musimy z tym walczyć! Wiem, jakie skutki to przynosi.

Drugą wielką postacią rolnictwa ekologicznego w Polsce był Julian Osetek, który jeszcze w czasach PRL propagował biodynamiczne metody w rolnictwie istosował je na własnym gospodarstwie począwszy od początku dekady lat 60 minionego wieku. Metody biodynamiczne były aktywnie propagowane przez niego i zaprzyjaźnionych z nim niemieckich rolników na kursach Ekolandu na początku dekady lat 90. Potwierdzenie wielkiej roli wpływu Osetka znajdujemy w relacji Piotra Hillara, znanego rolnika i młynarza ekologicznego:

Pod koniec lat siedemdziesiątych na mojej drodze stanąt rolnik doktor, który wprawdzie zarazil mnie mitościa do ziemi, ale niestety, nauczyt zasad rolnictwa opartego na chemii, z jedyna modyfikacjac, która stanowita uprawa ziemi $<<$ bez pługa >>. Tak powoli, prowadzac nadal ustugi tartaczne, stawatem się rolnikiem. $W$ międzyczasie ukończyłem zaoczne studia na SGGW w Warszawie na wydziale technologii drewna. Jako początkujący rolnik zaczątem studiować drugi fakultet - rolnictwo. Wtedy tė̇ $w$ moim życiu 
pojawit się drugi nauczyciel, pan Julian Osetek i przekonat mnie do uprawy ziemi dalece różniącej się od tej, którq̨ znałem. W ten sposób zostatem neofita rolnictwa biodynamicznego. Byt to marzec $1983 \mathrm{r}$. Studia rolnictwa konwencjonalnego nie przystawaty do poznawanej metody. Na drugim roku zrezygnowatem więc z nauki i zajątem się z catym oddaniem nową metodą. (Sottysiak 1995: 99).

Zainspirowany przykładem człowieka żyjącego ideą rolnictwa ekologicznego, nasz bohater podejmował decyzję o dołączeniu do ruchu eko-rolników i wprowadzenie radykalnych zmian $\mathrm{w}$ swym gospodarstwie. Tak przynajmniej było przez dekadę lat 90, gdyż w ostatnich latach zaobserwować można słabnącą rolę autorytetów i rosnące znaczenie informacji o finansowych korzyści płynących z dopłat unijnych.

Rola Osetka w upowszechnianiu metody biodynamicznej była ogromna. Należy tu wspomnieć, że biodynamika jest trudną metodą, wymagającą wielu niekonwencjonalnych praktyk i pełnego zaufania do sił przyrody, gdzie nawet podlewanie upraw uchodziło za nadmierną ingerencję człowieka w świat przyrody. Jak wspomina pewna rolniczka:

Wiesz, bo ta biodynamika jest już taka bardzo...jest to taka glęboka jedność z kosmosem, jakby z tymi siłami kosmosu. Bo to polega tam na mieszaniu, mieszasz te preparaty $i$ mieszasz, no musisz nawet z pót godziny $i$ jeszcze wszystko robisz ręcznie, lub z jakimś mieszadlem, ale chodzi o to, aby człowiek $w$ tym byl, jakoś $w$ tym uczestniczyt. Ciekawe, no bo ten Julian Osetek to on nie wszystkich, jak ktoś do niego napisat to nie wszystkim przysylat te preparaty. On jakoś do tych ludzi na odlegtość, ale on wyczuwat czy ta osoba może ta biodynamikę stosować, czy ma predyspozycje, tak że to też byto dość takie ciekawe (śmiech). No i przede wszystkim pana Osetka już nie ma wśród nas, już odszedt, zmarl, no i może dlatego jeszcze gdyby on żyt, to może bym jeszcze...ale już nie miał takiego zastępcy, syn nie przejąt tego, no i dlatego tych preparatów już brakto, no i przestałam to stosować.

W świetle przytoczonej wypowiedzi Osetek jawi się również jako charyzmatyczny lider, posiadający bezbłędną intuicję. W jego publikacjach można znaleźć potwierdzenie faktu, iż ów propagator biodynamiki zwracał uwagę na rolę czynnika świadomościowego w produkcji rolnej, mógł uwzględniać nastrój i postawę rolnika, aby ocenić czy nadaje się on na adepta biodynamiki: owoce jego ( $t$ j. rolnika -przyp. PB.) zależa $w$ sposób istotny od tego, $w$ jakiej świadomości i nastroju oddaje się 
pracy na roli, $w$ odróżnieniu od pracy $w$ przemyśle, gdzie produkt głównie zależy od maszyny-automatu (Osetek i Osetek 1989: 12).

\subsection{Pobieranie nauki i obserwowanie}

W relacjach pionierów polskiego eko-rolnictwa po przeżyciu żywego doświadczenia inspiracji ze strony największych propagatorów eko-rolnictwa i uczestnictwa $w$ ich kursach, pojawia się jako ważna faza konieczności poznania tajników funkcjonowania gospodarstwa ekologicznego, tak $\mathrm{w}$ zakresie technik rolnych, jak i w wymiarze społeczno - ekonomicznym. Ważnym epizodem była możliwość wyjazdu zagranicę, celem obserwacji tamtejszych gospodarstw ekologicznych, mających znacznie większe doświadczenie niż raczkujące polskie ekorolnictwo. Znamienne, iż polscy rolnicy zaobserwowali w Austrii, Niemczech, Szwajcarii czy Francji działania drobnych przetwórni przy gospodarstwach i zdobyli motywacje do otwarcia analogicznych przetwórni we własnych gospodarstwach, dając impuls do rozwoju najbardziej renomowanych polskich przedsiębiorstw ekologicznych. Tadeusz Szynkiewicz, założyciel wytwórni soków BIOS wspomina:

Wtaściwie o przetwórstwie pierwszy raz zaczałem myśleć $w 1990$ r., po powrocie z praktyki $w$ gospodarstwie ekologicznym we Francji. Będąc tam, miatem okazję zobaczyć kilka przetwórni ekologicznych, głównie małych mleczarni, i idea ta bardzo mi się spodobała. (Sottysiak 1995: 115)

Bogusław Klimczak, założyciel wytwórni serów inspiracje czerpał z Niemiec: wcześniej miatem okazję zwiedzić kilkanaście gospodarstw biodynamicznych $w$ Niemczech $i$ Szwajcarii, z rozwiniętym matym przetwórstwem, co tam jest rzeczq normalnq. (Soltysiak ibidem: 108)

Mieczysław Babalski, twórca wytwórni makaronu o powszechności przetwórstwa przekonał się w Szwajcarii:

w 1988 roku wyjechałem na 3-miesieczna praktykę zakończona 3tygodniowym kursem rolnictwa biodynamicznego $w$ Szwajcarii. (...) Pobyt $w$ Szwajcarii uświadomit mi, że $w$ każdym mniejszym gospodarstwie oprócz produkcji rolniczej prowadzi się przetwórstwo, wytwarzajac przetwory mleczne (sery, jogurty, kefiry, twarogi), soki, przetwory warzywne, różnego rodzaju mąki, kasze, makarony i chleb (Sottysiak ibidem: 105) 
W ostatnim czasie ważną inspiracją dla młodszych stażem był wyjazd na największe światowe targi eko-rolnictwa - odbywający się co roku w Norymberdze BIOFACH. Obecnie eko-rolnicy mogą liczyć na wsparcie instytucjonalne ze strony samorządów, dostrzegających rosnące znaczenie i prestiż eko-rolnictwa i liczących na własną promocję przykład Mazowiecki Urząd Marszałkowski zorganizował wycieczkę na owe targi dla kilkudziesięciu rolników ekologicznych. Obecnie jest również łatwiej o obserwowanie innych gospodarstw w Polsce, Ośrodki Doradztwa Rolniczego organizują wyjazdy studyjne do doświadczonych eko-gospodarzy dla początkujących rolników. Jest znacznie większa oferta stowarzyszeń i kursów.

4.5 Bariery: drwiny ze strony pierwotnej grupy odniesienia i niskie plony

Rolnik, który podejmował się dzieła przejścia na metody ekologiczne pod wpływem nowych znaczących innych, spotykał się często z niezrozumieniem i drwinami ze strony swego najbliższego otoczenia, rodziny i sąsiadów. Oto fragment narracji mazowieckiego eko-rolnika z 12-letnim stażem:

Na początku jest najgorzej, trzeba taka bariere przetamania, nie tylko $w$ sobie. Bo to sasiedzi patrzq i inni podśmiewaja się, bo teraz to się dużo mówi o ekologii, robi się modna, ale tam $w 95$ roku to byli tacy, co chodzili podśmiechiwali się $\mathrm{z}$ tego, z upraw ekologicznych, bo pare minut od mnie miat taki konwencje $i$ miat duże plony i uprawiane to byto bez problemów, bo byty herbicydy, a tutaj wszystko zarastało. Człowiek, co przechodzil na ekologii to trzeba było przełamać bariery typu psychologicznego, mentalnego $i$ to nie tylko $w$ sobie by przejść na ekologie, teraz ekologia jest na fali, już nie trzeba. W tej chwili jest inaczej, od wejścia do Unii dużo tatwiej.

Podobny proces ilustruje wypowiedź lódzkiego eko-rolnika:

Wieś to jest taka mała komórka, gdzie, jeśli się dzieje coś niezrozumiatego, nowego, raczej jest się jakimś dziwakiem, wyśmiewanym. Wiadomo, wszystko, co dobre, musi też świecić przykładem, jak gdyby ludzie się po matu przekonują. Te dotacje, które daje jak gdyby Unia na rozwój tego kierunku, i jeżeli widzq, że coś się dzieje $w$ tym kierunku, że to się opłaci, zmieniają zdanie. $\mathrm{Na}$ początku się śmiali, bez nawozów to nic za 5 lat nie będzie rosto mówili. A teraz jest czternasty rok, no $i$ nic się nie zmienito. Wszystko rośnie. 
Szyderstwa sąsiadów, dotychczasowej grupy znaczących innych, okazywały się jedną z przeszkód, z jakimi radzić sobie musieli początkowi eko-rolnicy. Początkowo odmienność rolnika jest postrzegana jako dziwactwo, rolnik przechodzący na metody ekologiczne zwłaszcza w latach 90-tych, gdy proces społecznej legitymizacji tej formy rolnictwa był $\mathrm{w}$ początkowej fazie, spotykał się $\mathrm{z}$ drwinami i wyrazami braku szacunku. Mówienie o ostracyzmie społecznym byłoby raczej przesadą, lecz na pewno podkreślenie własnej inności nie wzbudzało sympatii, codzienne wyrazy traktowania z przymrużeniem oka. Pewien łódzki eko-rolnik, który w 1992 przeszedł na metody ekologiczne opowiadał mi, iż sąsiedzi zaczęli nazywać go pogardliwie Jehowcem, termin pochodzący od raczej negatywnie nacechowanego emocjonalnie określenia członków grupy wyznaniowej Świadków Jehowy, w tym wypadku służącym za synonim odszczepieńca. Obydwaj rolnicy zwracają uwagę, iż zwłaszcza w pierwszej dekadzie funkcjonowania rolnictwa ekologicznego opór i niezrozumienie ze strony sąsiadów było silne, lecz dziś dochodzi do zjawiska akceptacji, oswojenia ekologii ze względu na fakt, iż instytucje państwowe są zaangażowane w promocję tej formy rolnictwa i wiąże się ona z korzystnymi dopłatami. Kiedyś ich wyśmiewano, teraz się im przyglądają z zaciekawieniem. Przetrwanie tej próby polegało na wytrwałości. Wykazać należało, iż mimo braku syntetycznych nawozów wszystko rośnie. Tylko za pomocą konkretnych argumentów, takich jak efektywność produkcji, a nie za pomocą ideologii mogły zjednać akceptację i powtórny szacunek sąsiadów.

Potwierdzenie takiej tezy znajdujemy $\mathrm{w}$ narracji eko-rolnika $\mathrm{z}$ Mazowsza, trzeba się wykazać dobrymi wynikami by przekonać sąsiada-szydercę do własnych metod:

$Z$ tym, że ja $w$ moim rejonie, mojej wsi to ja jestem po prostu jedyny.

Sąsiedzi mnie traktowali z początku z przymrużeniem oka. Pamiętam jak sasiad pokazal mi, podam taki przyklad humorystyczny, a musze powiedzieć, że wtedy uprawiatem jeszcze burak cukrowy, pokazat mi kieliszek i powiedziat, że u mnie burak będzie taki, pokazat szklankę i powiedziat, że u niego będzie taki. Ale akurat wyszto, że to mój byt większy. Nie mógt uwierzyć. Rolę tu odgrywa plodozmian, gdy jest odpowiedni ptodozmian to wystarczy, wszystko wyrośnie odpowiednio duże (podkr. PB.).

W innej narracji znajdujemy ten sam przebieg historii: początkowe drwiny najbliższego otoczenia, które ustają w momencie znalezienia własnej formuły gospodarstwa i sukcesu finansowego. Wówczas drwiny zastępuje respekt i zaciekawienie. Kluczowym czynnikiem jest odwaga eko-rolnika, gotowość akceptacji 
etykiety osoby kontrowersyjnej, wymagającej pewnej dozy nonkonformizmu. Ważne jest by rolnik był pogodzony z koniecznością początkowej utraty statusu społecznego, aby cierpliwie wyczekiwać odzyskania go $\mathrm{w}$ momencie wykazania się dobrymi wynikami, gdyż tylko dobra ocena według kryteriów aksjologicznych rolnictwa konwencjonalnego może zapewnić mu uznanie otoczenie (tj. wydajność, rozmiar warzywa, wyniki finansowe). Ilustracje tego procesu znajdujemy w narracji innego eko-rolnika, dawniej uznawanego za dziwaka, a obecnie będącego najbardziej zamożnym mieszkańcem swojej wsi:

Znaczy ja powiem nie tylko o sasiadach, bo ja powiem o najbliższych, znaczy, że wielu ludzi uważato, że coś mi się poprzestawiało $\boldsymbol{w}$ gtowie, albo fiksuje albo po prostu wymyślam jakieś //, znaczy ja zawsze byłem osoba kontrowersyjna bez względu na to czy to byla szkoła średnia czy to była już tutaj powiedzmy, ten okres. Natomiast ja mówię zawsze, że ludzi się rozdziela nie po tym, co robia, tylko po wynikach. No iwmomencie, kiedy te wyniki się już pojawity to i myślenie tych ludzi się zmienito radykalnie, nie? (podkr. $P B)$

Dużo większą trudnością był znaczący spadek plonów w pierwszych latach gospodarowania, który był udziałem niemal każdego adepta rolnictwa ekologicznego, związany z koniecznością obniżenia standardu życia, niekiedy zadłużenia się. Pierwsze trudne lata to rodzaj duchowej próby, ci, którzy jej podołali dzięki wierze w sens swej decyzji zdobyli wytrwałość i hart ducha, które najczęściej w przyszłości przyniosły im owoce $\mathrm{w}$ postaci bogatych plonów i przyzwoitego wynagrodzenia. Rolnicy bez silnego powołania zaś decydowali się natychmiast na powrót do pryskania. Oto ten epizod w narracji mazowieckiego rolnika:

Byly, powiem szczerze różne wzloty $i$ upadki, dlatego, że w produkcji sadowniczej nie jest ta produkcja tak tatwa jak w produkcji, powiedzmy sobie, $w$ warzywach czy produkcji szklarniowej, gdzie nie ma takiej ingerencji szkodników, chorób. Tutaj byto tak, że $w$ pierwszych latach miatem nawet $80 \%$ strat $w$ plonach, później dopiero się jakoś to unormowało, ale $w$ produkcji ekologicznej z sadem jest tak, że ileś lat musi to minąc by doszto to produkcji na poziomie, by to się jakoś wyrównywato.

Inny mazowiecki rolnik mówił o tym, iż $\mathrm{w}$ początkowych latach ziemia chorowała, jakby musiała się wyleczyć po kilkuletniej infekcji środków chemicznych: 
Poczatki byty bardzo trudne, bo rynki zbytu nie istniaty jak teraz, samemu trzeba była szukać. Te pierwsze lata były najgorsze, bo po kilku latach stosowania chemii to ziemia, że tak powiem chorowała, spadek płodności do 6o\%, inwazja chwastów, owadów i nie można byto sprzedawać pod znakiem ekologii $w$ trakcie przestawiania. Ciężko było te dwa lata przeżyć.

Inny eko-rolnik, który $\mathrm{z}$ dumą poinformował mnie o swoim dużym doświadczeniu: byłem trzydziesty drugi $w$ catym kraju, wspominał, iż sytuacja początkowa była bardzo trudna. Podobnie jak jego poprzednik wskazuje fakt braku rynku ekologicznych płodów rolnych, a zmiana sposobu gospodarowania powodowała chwilowe zakłócenie plonów:

Początki jednak były tragiczne - susza, zachwianie równowagi przyrodniczej. Nie było sklepów ekologicznych, ODR jakoś próbowat organizowat transport płodów. Ale tatwo to nie byto.

Ratunkiem było zabranie się za produkcję i zadbanie o jej jakość i dystrybucję. Powyżej cytowany rolnik zaczął regularnie jeździć na kiermasze do dużych miast, cieszy się, że ma klientów, którzy kupują u niego nieprzerwanie od 1992 roku. Jego formułą była skrupulatna nauka i oparcie się na uczciwości:

Trzeba było nauczyć się handlu, siać to, co trzeba i oprzeć się można tylko było na uczciwości, jak się oszuka raz, to klient nie wróci. Mam trochę klientów, co do mnie przyjeżdża do gospodarstwa, niektórzy nawet $150 \mathrm{~km}$, alergicy, chorzy, błagaja mnie bym zachowat dla nich warzywa. Ja na nich mówię "chodzace laboratoria" bo jakby coś było nie tak z mym jedzeniem, to oni to od razu wykryja (podkr. PB).

4.6 Poszukiwania własnej formuly gospodarstwa

Rolnikom ekologicznym, tak jak archetypowi kulturowemu chłopa właściwa jest praktyczna natura i zamiłowanie do konkretu. Objawia się ona w zamiłowaniu do empiryzmu - chęci praktycznego sprawdzenia rezultatów proponowanych technik. Pierwsze lata rolnictwa ekologicznego oznaczały dominacje biodynamiki uznawanej wówczas za główną szkołę eko-rolnictwa. Sianie zgodnie z fazami Księżyca i jego ruchem w stosunku do Zodiaku czy niekonwencjonalne techniki biodynamiczne, takie jak zakopywanie krowiego rogu, wywoływały dysonans poznawczy. Intuicja i aktywne eksperymentowanie okazują się ich metodą. Znamienne, iż jeśli rolnicy decydowali 
się stosować techniki biodynamiczne, początkowo aplikowali je na części pól by porównać rezultaty i jedynie, gdy zdobyli empiryczne potwierdzenie decydowali się na zastosowanie biodynamiki w całości gospodarstwa. Niekiedy rolnicy dochodzili do dysonansu poznawczego, na przykład pod wpływem poznania dwóch wersji kalendarza księżycowego, w sytuacji tej zwycięża własna mądrość, własny nos poparte metodyczną obserwacją wyczucie.

Oto relacja pewnej rolniczki z lódzkiego:

Też się zajmowałam tym sianiem wedhug faz księżyca, wedhug tych dni, które sa ptodne, $w$ tych znakach płodnych, a tych jałowych by nie siać, to też przez kilka lat stosowałam, ale okazało się, że różne sq na ten temat szkohy. Te kalendarze sq inaczej pisane, te biodynamiczne to byly wedhug Osetka i biodynamików z Niemiec głównie i $w$ Polsce tu też taki jest taki... Przybylak, on też układa kalendarze $i$ wiesz, one sq różne, inne dni sq do siewu, inne wiesz...później to zaprzestałam, bo wtaściwie nie wiedziałam, kogo mam wybrać, czy tego Przybylaka czy tamtych? (śmiech). Później $z$ rolnikami rozmawiałam na ten temat i teraz tylko przestrzegam, że wiem, kiedy jest od petni do nowiu, a kiedy od nowiu do petni, kiedy nie warto siać to tego przestrzegam, od petni $w$ czwartej kwadrze do nowiu nie sieje, bo to jest dobry okres do pielenia, do niszczenia. Teraz to patrzę na niebo i wedhug zwykłego kalendarza wiem, kiedy siać, a kiedy nie.

We fragmencie tym mamy do czynienia z opisem sytuacji uczenia się. Ucząc się języka na początku korzystać możemy z rozmówek, ale gdy osiągniemy pewien poziom płynności, możemy się bez nich obyć. W przypadku gotowania młodym adeptom niezbędne są przepisy, ale gdy osiągną wprawę, sami potrafią eksperymentować. Podobnie zdaje się być w rolnictwie, rygorystyczne przepisy mogą być pomocne dla początkujących, a wytrawny rolnik rozwija sukcesywnie własne wyczucie, aby móc obejść się bez pomocy naukowych.

W relacji innego eko-rolnika znajdujemy ciekawy przykład odwiecznego problemu teologii - pogodzenia fides (wiary) i ratio (rozumu):

R. Wszystko, co ja to robilem, robitem z sercem. Nie robilem (...) doświadczeń, że pót pola, załóżmy zrobilem, tylko robilem wszystko. Wierzyłem $\boldsymbol{w}$ to, bytem przekonany o stuszności tego. Robitem doświadczenia z kalendarzem (podkr. PB.).

B. Księżycowym?

R. Tak. Bo to tak się pierwszy raz zetknątem, może prawda, może nie. I tak doświadczenia zrobilem, bo jak to na studiach widziatem, jak oni robia te doświadczenia rolnicze, to tak już mniej więcej tak jak oni robilem. Zrobitem drugie powtórzenie, bo tak jak się zmienia 
miesiac, co dwa tygodnie tam się zmienia. Owoc - korzeń, nie? $W$ tym kalendarzu pani Thun mówię, to Księżyc wedhug Zodiaka przechodzi. Jak księżyc zmienia, co dwa tygodnie wchodzi na ten zodiak, tak rzodkiewke siatem. I tak przez miesiac rzodkiewkę siałem $w$ każdym znaku i wyszło jak na dłoni, tak pięknie wyszło, że kalendarz się potwierdzit. I go stosuje z calym przekonaniem.

Ciekawym aspektem adaptacji przez rolników nieznanych wcześniej technik, zasadzających się na współdziałaniu człowieka z kosmicznym światem przyrody jest własne podejście lączące wiarę $\mathrm{z}$ empiryzmem, godzące autentyczną wiarę w kosmiczną harmonię z praktycznym eksperymentowaniem, właściwym nauce. Jest to rodzaj integracji dwóch rodzajów racjonalności, pogodzenie wiary z rozumem.

W swej książce Ekofilozofia rolnictwa, ojciec polskiego eko-rolnictwa, Mieczysław Górny (1992) uznał, iż aktywne eksperymentowanie, ciągłe interakcje z Przyrodą, staranie dostosowania technik do jej warunków, działanie w warunkach niepewności jest integralną częścią rolnictwa ekologicznego:

Ideq rolnictwa ekologicznego jest pokora wobec przyrody, uznanie jej nierozpoznawalności, a więc konieczności ciąłego jej obserwowania i badania przez cztowieka, starania dopasowania się $i$ wspótpracy $z$ nią. Ta elastyczność opinii $i$ zalecanie ciąglego weryfikowania poglądów wytyka się często jako słabość rolnictwa ekologicznego. Rzeczywisty staby punkt, przynajmniej we wspótczesnych warunkach wciąż jeszcze technicznego myślenia, tkwi przede wszystkim w ekskluzywności tego rolnictwa, zwiazanej $z$ wyższymi wymaganiami intelektualnymi i moralnymi, jakie stawia ono rolnikowi (s. 17).

Ważnym i dalszym etapem stawania się rolnikiem ekologicznym jest profesjonalizacja rolnictwa ekologicznego. Poznałem przykłady gospodarstw ekologicznych, które oparły się intencjonalnie temu procesowi. Niektórzy mają tylko małe gospodarstwa nie produkujące na rynek, stanowiąc typ eko-rolników kontemplacyjnych, tak jak wspólnota katolicka Ognisko Miłości z Rogowa, dla której rolnictwo ekologiczne pełni charakter prostej, fizycznej pracy, służby Bogu i wspólnocie, która nie odczuwa konieczności komercjalizacji produkcji, gdyż dysponuje alternatywnymi źródłami przychodu. Dynamiczny rozwój w ciągu ostatnich lat pozwala przypuszczać, iż częściej na taką formę prowadzenia gleby zdecydowali się rolnicy niemotywowani pobudkami ideowymi, lecz rachunkiem ekonomicznym (tzw. eko-rolnicy dotacyjni). Ludzie, którzy od kilkunastu lat zajmują się eko-rolnictwem zdecydowali się na konwersję głównie z przyczyn ideowych, 
zafascynowania ideami ekologicznymi czy też metodami biodynamicznymi Steinera opierającymi się na idei kosmicznej współzależności. Rolnicy ci przeżywali pewne napięcia w związku z koniecznością dostosowania się do rynkowych reguł gry. Oto, jak proces profesjonalizacji opisuje rolnik zajmujący się m.in. rękodzielniczym wypiekiem chleba tradycyjnymi metodami:

Znaczy tak gdzieś od 90 roku ja piektem go dla siebie, dla wlasnego spożycia. Ale tak no jak ktoś byt to zawsze częstowaliśmy, ten ktoś wotal, no wiesz mógtbyś mi wypiec jeden bochenek więcej, to ja bym wziat. Tak sie to powoli jakby przyjmowato. Pierwsze to ja myślatem, że sa to takie kurtuazyjne mówienia. Wypieczenie chleba sprawia duża satysfakcję, każdy, kto piekt wie o tym. (śmiech). Samemu dla siebie, nie mówię o komercyjnej sprzedaży. To jest chyba większa satysfakcja niż upiec pqczki. Upiec chleb to rzadziej się zdarza. I myślałem z poczatku, że to jest taka kurtuazja, ten chleb komuś wypiec. Piekłem już dwa, potem trzy dla kogoś, potem pięć. To nie jest piekarnia, to jest rękodzieto domowe. Robimy to $w$ osobnym pomieszczeniu, nie $w$ domu, ale wcześniej to $w$ kuchni $w$ domu. A teraz to jest już // no na pewien przychód to robimy.

Uwidacznia się pewne zawstydzenie związane z koniecznością komercjalizacji działalności i problem z określeniem jej charakteru: chałupnictwo to już nie jest, ale firma jeszcze nie. Przywołany eko-rolnik woli określić swoja piekarnię, jako rękodzieto domowe, kategorie zawierającą pewną dumę z własnej twórczości, przybliżającą go do społecznego świata rzemiosła i sztuki. Przyznaje, iż wypiek chleba stał się dla niego działalnością przynoszącą zarobek, lecz ma problemy z określeniem jej, nie nazwie organizacji swej działalności mianem piekarni ani firmy czy zakładu, gdyż chce podkreślić swój dystans wobec społecznego świata biznesu, skąd pochodziłyby owe kategorie. Rolnik ów przeżywa ważny proces poszukiwania własnej formuły, jego działanie nie jest już zwykłą przygodą, ale nie ma się stać zwykłem biznesem. Jest to proces godzenia własnych przekonani ideologicznych, misji $\mathrm{z}$ wymogiem zawodu - zarabiania na własną rodzinę.

\subsection{Punkt optymalny}

Istotnym wyzwaniem $\mathrm{w}$ profesjonalizacji jest uchwycenie własnego momentu optymalnego: osiągnięcie takiej wielkości działalności gospodarczej, która przynosi satysfakcję i wystarczające środki finansowe. W firmach ekologicznych ideałem jest bowiem osiąganie optymalnego rozmiaru działalności zamiast idei nieograniczonej 
ekspansji. W ten sposób rolnicy ekologiczni mogą aspirować do miana grupy zorientowanej postmaterialistycznie, gdyż osiągnąwszy podstawowy materialny standard życia wyżej cenią sobie jakość życia, czas na odpoczynek. Zdaniem znanego badacza tendencji w obszarze światowego rynku pracy, autora Końca Pracy, Jeremy'ego Rifkina właśnie pogodzenie pracy z odpoczynkiem będzie największym wyzwaniem XXI wieku. Świadomość punktu omega pojawia się u doświadczonych rolników ekologicznych. Oto fragment reportażu prasowego poświęconego Aleksandrze i Mieczysławowi Babalskim (Bubula 2004), pionierom eko-rolnictwa i właścicielom przetwórni makaronów, gdzie zatrudnione są 4 osoby i wedle relacji dziennikarki panuje rodzinna, domowa atmosfera:

Pytam Mieczysława Babalskiego, czy nie myślał o powiększeniu gospodarstwa, rozbudowaniu wytwórni, zatrudnieniu większej liczby pracowników. Myślat, ale świadomie nie chce iść tą droga. Jest wrogiem zaciagania kredytów "na rozwój", uważa, że ten rozmiar rodzinnej firmy jest $w$ sam raz. Jest praca, niezbędne środki do utrzymania i stabilna sytuacja. Woli popularyzować ideę takich gospodarstw izachęcać innych rolników do upraw ekologicznych i powrotu do starych, niestusznie porzuconych $w X X$ wieku odmian i gatunków roślin.

W podobny sposób myśli producent mleka i serów $\mathrm{z}$ woj., zachodniopomorskiego:

Ja powiem tak, ja się cieszę, że mam taka powierzchnię, cieszę się, że mam takie stado, natomiast wiem o tym, że ani tej powierzchni nie chce mieć już dzisiaj większej, ani tego stada większego, bo osiagnąem jakiś optymalny poziom, gdzie można mieć petna kontrole nad zarówno uprawami, hodowla i przetwórstwem (podkr. $P B$ ).

Rozpoznanie punktu optymalnego jest z pewnością udziałem nielicznych, doświadczonych eko-rolników, którzy przeszli długą drogę poszukiwania własnej formuły gospodarstwa i można powiedzieć, że zbliżyli się do ostatniego stadium rozwoju tożsamości eko-rolnika, mając zapewniony satysfakcjonujący poziom życia, w większym stopniu mogą poświęcić się promowaniu eko-rolnictwa i eko-żywności. 


\section{Gtówni aktorzy społecznego świata. Charakterystyka organizacji rolników ekologicznych.}

W przypadku rolnictwa ekologicznego obserwujemy proces wewnętrznej implozji organizacyjnej (Por. Konecki 2005: 88), powstawania nowych zrzeszeń w oparciu o odmienne postrzeganie rzeczywistości. Fakt ten staje się zrozumiały, gdy zdamy sobie sprawę, że mamy do czynienia $z$ dynamiczną i emergentną rzeczywistością młodego świata społecznego z niewielką liczbą ukształtowanych stałych instytucji i praktyk. Obecnie działa w Polsce blisko 50 stowarzyszeń dążących do rozwoju rolnictwa ekologicznego ${ }^{3}$. Trudno jest o dokładne dane, wiele jest przypadków granicznych - np. stowarzyszeń, które stawiają sobie za cel rozwój kultury wiejskiej czy rozwój wsi, zrzeszając również eko-rolników i czyniąc z rozwoju tej dziedziny jeden z celów. Ciągle pojawiają się nowe podmioty. Przykładowo, 3 lutego 2007 miałem przyjemność uczestniczyć w spotkaniu założycielskim Łódzkiego Stowarzyszenia Producentów Ekologicznych "Biorolnik". Grupa kilkunastu rolników ekologicznych i sympatyków rolnictwa ekologicznego zdecydowało się powołać lokalne stowarzyszenie, dążące do promocji rolnictwa ekologicznego, produktów ekologicznych i tradycyjnych, a także integracji rolników ekologicznych, zmierzającej do wyłonienia wspólnej grupy producenckiej. Inicjatorami powołania stowarzyszenia byli właściciele łódzkiego sklepu z ekologiczną żywnością. Wśród zebranych dominowało przekonanie, iż ogólnopolskie struktury najstarszej organizacji eko-rolniczej - Ekolandu okazują się być zbyt wielkimi i przez to dolega im słaba skuteczność. Często pojawiały się opinie, iż skutecznie można działać jedynie w skali jednego województwa i, że nie warto przekazywać 60\% składek na rzecz krajowego zarządu i ogólnopolskich działań. Zebranie zostało zwołane z zamiarem zachowania kapitału w skali lokalnej i koncentracji na produkcyjnym potencjale lokalnych zasobów. Rolnicy myślą o tworzeniu wspólnej oferty handlowej, zabieganiu o dofinansowanie ze strony Urzędu Marszałkowskiego na wspólny wyjazd na największe targi rolnictwa ekologicznego - niemiecki Biofach.

Stowarzyszenia eko-rolników są podstawowymi aktorami badanego świata społecznego. Ich celem jest podstawowe działanie świata społecznego, jakim jest ekologiczna produkcja żywności, rozumiejąc przez to tak uprawy, jak i przetwórstwo oraz organizację sprzedaży.

\footnotetext{
${ }^{3}$ Szacunki własne w oparciu o informacje otrzymane od jednostek certyfikujących.
} 
Zamiast prezentować skrótowo wszystkie znane mi stowarzyszenia, zdecydowałem się przedstawić trzy studia odmiennych przypadków: największej organizacji ogólnopolskiej, organizacji o charakterze lokalnym i klastra regionalnego systemu integrującego różne organizacje i instytucje.

5.1 Ekoland jako największa i najstarsza ogólnopolska organizacja

Najstarszym i największym zrzeszeniem rolników ekologicznych w Polsce jest Stowarzyszenie Producentów Żywności Metodami Ekologicznymi Ekoland, powstałe 1 września 1989 roku. Stowarzyszenie zrzesza obecnie blisko 600 rolników ekologicznych. Stowarzyszenie zostało założone przez rolników, którzy poznali się przy okazji kursów rolnictwa biodynamicznego udzielanych przez ekspertów z Niemiec i Szwajcarii, organizowanych przez Juliana Osetka i prof. Mieczysława Górnego z SGGW.

Ekoland odegrał niezmiernie ważną rolę w konsolidacji ruchu społecznego ekorolników. Od 1991 roku rolnicy zrzeszeni w Stowarzyszeniu wspólnie tworzyli stoiska na kiermaszach w Warszawie, a potem dalszych miastach Polski by następnie skupić się na przedstawianiu oferty wyspecjalizowanym sklepom. Wspólnie rozwijali również sieci sprzedaży bezpośredniej. Wielu doświadczonych rolników ekologicznych z rozrzewnieniem wspomina okres początków lat 90, kiedy brali udział w kiermaszach Ekolandu na warszawskiej Ochocie. Oto jak wspomina ten epizod ekorolnik i młynarz z Pomorza Piotr Hillar:

Dziś wydaje się to dziwne, lecz $w$ owych latach produkcja mleka była nie tylko nieopłacalna, ale poniżej wszelkich kosztów utrzymania krów. Zmuszato nas to do myślenia, co zrobić, żeby sprzedać mleko? W 1990 r. z pomoca zaprzyjaźnionego biodynamicznego rolnika $\mathrm{z}$ Niemiec, Christofa Klemmera i jego przyjaciót, kupiliśmy samochód, co pomogło nam $w$ sprzedawaniu naszych ekologicznych produktów. Co tydzień jeździliśmy do Warszawy na kiermasz przy klubie EKO-OKO na ulicę Grójecką. Byt to duży wysitek, ponieważ odlegtość od nas do Warszawy wynosi $180 \mathrm{~km} w$ jedna stronę. Tam sprzedawaliśmy warzywa, mleko i jego przetwory (twaróg, masło, śmietanę), ziarno i makki razowe. Przygoda ta trwata 2 lata. Obecnie wspominamy z rozrzewnieniem kolejki nabywców, którzy z wielką cierpliwością oczekiwali naszego przyjazdu z produktami. (Soltysiak 1995: 100-101) 
Oprócz stymulowania rozwoju rynku produkcji ekologicznej, do 2000 roku Ekoland zajmował się atestacją gospodarstw ekologicznych, stosując własny, innowacyjny system atestowania opracowany przez powołany przy organizacji Konwent Ekologiczny pod przewodnictwem prof. Mieczysława Górnego i innych ludzi nauki w nawiązaniu do podstawowych kryteriów IFOAM. Urszula Sołtysiak, członek zarządu spółki certyfikującej AgroBioTest, a dawniej członek Konwentu wspomina: Osobliwym wyróżnikiem tego przedsięwzięcia byt - dziś to nie do pomyślenia brak dokumentu odniesienia! Podstawa kontroli gospodarstw w latach 1990-93 była nieskodyfikowana wiedza: przekazywana - na licznych kursach rolnictwa ekologicznego, organizowanych przez Stowarzyszenie EKOLAND - zarówno rolnikom wnioskującym o kontrolę, jak $i$ tym, którzy podjęli się kontrolowania...(www.agrobiotest.pl). Wynika z tego, że we wczesnym etapie konsolidacji rolnictwa ekologicznego, intuicja ekspercka była wystarczającą podstawą do oceny gospodarstw.

Można śmiało powiedzieć, iż do końca lat 90. przynależność do świata rolnictwa ekologicznego była tożsama z członkostwem w Ekolandzie, będącym organizacją kontrolująca rolników i reprezentującą ich interesy. Nie było wówczas innego dowodu ekologiczności upraw niż członkostwo w omawianym zrzeszeniu, nie istniały konkurencyjne organizacje eko-rolników. Oto opowieść o dawnym Ekolandzie jednego z mazowieckich rolników, którego można by zaliczyć do pionierów eko-rolnictwa:

\begin{abstract}
Pierwszym zaczątkiem tego byt Ekoland, byłem czlonkiem Ekolandu, wtedy po prostu statem się członkiem Ekolandu $i$ byty kontrole, od razu Ekoland byt między innymi jednostka kontrolna, wszystko się dziato $w$ Ekolandzie. Ja się dowiedziatem o tym na jakimś festynie, jakiejś wystawie, wtedy byto tych rolników ekologicznych niedużo, 50, 8o, może mniej. Wtedy było tak, że ludziom może nie zależało na pieniądzach $w$ ekologii, wtedy zależało im na produkcji dla siebie, by mieć zadowolenie z tego, byli bardziej ludźmi oddanymi tej ekologii, nie zależało im na pieniądzach.
\end{abstract}

W przytoczonej opowieści czytamy, iż wszystko się działo w Ekolandzie, dla rolnika było czymś tożsamym przynależność do Ekolandu i do społecznego świata rolnictwa ekologicznego. W owej wypowiedzi wyraźnie rysuje się pewien obraz przeszłości, kiedy rolnicy nie martwili się pieniędzmi i byli całkiem oddani ekologii. Prawdopodobnie na ten obraz składają się pewne właściwe ludziom skłonności do 
idealizacji przeszłości, lecz w pewnym stopniu obraz ten oddaje atmosferę pierwszych lat, gdy pionierzy decydowali się na produkowanie żywności ekologicznej, mimo iż rynek zbytu ich produkcji nie istniał. Czynnik ideowy odgrywał wówczas dużo większą rolę niż obecnie $\mathrm{w}$ motywacji rolników, choć stwierdzenie, iż nie zależało im na pieniądzach, można poczytać za przesadną idealizację, gdyż historie pionierów to historie poszukiwań własnej formuly, walki o pogodzenie wyznawanych idei ekologicznych z imperatywem zapewnienia utrzymania własnej, często licznej, rodzinie.

Przypadająca na 2000 rok utrata prawa do certyfikacji, czyli decydowania o kryteriach przynależności do świata rolnictwa ekologicznego, to przełomowy punkt w historii Stowarzyszenia. Pomimo to, wielu rolników - twórców Ekolandu ciągle na swych produktach publikuje logo Stowarzyszenia, gdyż klienci ciągle je rozpoznają, choć formalnie o ekologiczności decyduje już atest udzielany przez niezależną od Ekolandu firmę. Znaczna część firm certyfikujących w naturalny sposób wyłoniła się z łona Ekolandu, dyrektor Bioeksperta, Dorota Metera, czy dyrektor AgroBioTestu, Urszula Soltysiak to naukowcy, długoletnie współpracowniczki Ekolandu.

Ekoland rozwinął skrzydła dzięki trwającemu 10 lat wsparciu instytucjonalnemu niemieckiej Fundacji im. Heinricha Bölla. Do 2000 roku Stowarzyszenie było $\mathrm{w}$ stanie prowadzić kilka biur i ośrodków informacyjnych, zatrudniać kilku etatowych pracowników, prowadzić szerokie kampanie promocji rolnictwa ekologicznego, wydać ponad 20 publikacji z zakresu rolnictwa ekologicznego i regularnie publikować kwartalnik Ekoland. Zakończenie finansowania z zagranicy przyniosło pewien kryzys w Stowarzyszeniu. Na swej stronie oficjalnej Stowarzyszenie przyznaje, iż efekt jego dotychczasowej pracy nie byt dla większości polskich rolników ekologicznych bezpośrednio odczuwalny, ponieważ ta działalność nie potrafita szybko poprawić rynku zbytu dla produktów rolnictwa ekologicznego (www.ekoland.org.pl). Obecnie Stowarzyszenie funkcjonuje dalej siłami samych rolników, nie mając środków na utrzymanie biura, wydawanie kwartalnika czy zatrudnianie pracowników. Wielu dawnych członków Ekolandu po tym, jak przekonało się, iż społeczne działanie jest czasochłonnym procesem, straciło zapał oraz złudzenia, co do łatwości zmiany społecznej i wystąpiło z Ekolandu, lub cieszy się statutem biernych członków. Słowa pewnego rolnika z łódzkiego zdają się oddawać dobrze relacje owych rolników z Ekolandem: Ja jestem takim niegrzecznym dzieckiem Ekolandu, nie pamiętam o nich, a oni o mnie pamiętają, mam zaległości 
$w$ sktadkach, a przesyłaja jednak mi broszury, w porzqdku są. Czasami Ekoland jest postrzegany jako organizacja pionierów: Ekoland jest teraz takim niszowym stowarzyszeniem, takim klubem seniorów (podr. PB.).

Cele Stowarzyszenia obejmują nie tylko upowszechnianie rolnictwa ekologicznego oraz promocję jego produktów wśród konsumentów, reprezentowanie interesów producentów, przetwórców i dystrybutorów produktów rolnictwa ekologicznego, lecz również szersze cele: działania na rzecz poprawy jakości życia na wsi, animację kultury wiejskiej czy działania na rzecz zrównoważonego rozwoju i ochrony przyrody. Siedziba główna Ekolandu w podtoruńskim Przysieku pozostaje jednym z najważniejszych punktów na mapie rolnictwa ekologicznego w Polsce, a organizowane co roku ekologiczne Dożynki w Przysieku to jedna z najważniejszych ogólnopolskich imprez eko-rolników. Zdaniem rolnika z zachodniopomorskiego i wieloletniego działacza Ekolandu, Przysiek to jest $w$ zasadzie cały czas serce tego naszego ruchu. Próbujemy to, byty próby przeniesienia tego $w$ inne miejsca ale zawsze to tam wraca. Ta grupa rolników jest najbardziej aktywna, najbardziej zorganizowana, no i najtatwiej tam jest się zorganizować.

Wszystkie istniejące dotychczas związki zawodowe rolników nie zaspakajały potrzeb eko-rolników, postanowili więc założyć własny. 2 czerwca 2006 roku w Warszawie został utworzony Polski Związek Zawodowy Rolników Ekologicznych. Główna inicjatywa wypłynęła od rolników zrzeszonych w Ekolandzie i obie organizacje są ze sobą ściśle połączone. Wśród celów nowopowołanego związku znaleźć możemy: reprezentacje i obronę interesów ekorolników, współudział w tworzeniu dotyczących ich regulacji, edukację ekologiczną, inspirowanie tworzenia gospodarstw ekologicznych oraz wspólną promocję produkcji ekologicznej (http://www.ekoland.org.pl/index.php?page=akt/zwiazki).

5.2 Eko-Centrum Zelów jako przyklad aktywnej organizacji lokalnej

Centrum Koordynacyjne Gospodarstw Ekologicznych i Agroturystycznych, w skrócie zwane Eko-Centrum Zelów to powstałe w 2003 roku stowarzyszenie rolników ekologicznych z powiatu bełchatowskiego, skupionych głównie wokół gminy Zelów. Wizja Eko -Centrum to instytucja pełniąca funkcje doradcze i wsparcia jako negocjator biznesowy, magazyn środków produkcji i produktów gotowych. EkoCentrum Zelów miało od początku silny wymiar marketingowy, stawiając sobie za cel 
wspieranie rolników w kreowaniu wspólnego wizerunku na rynku, konsolidację zmierzającą do wspólnego działania, a tym samym obniżania kosztów produkcji i organizacji sprzedaży. Wśród celów organizacji znajdziemy promocję rolnictwa ekologicznego, organizowanie szkoleń dla członków- rolników, jak i, w dalszej perspektywie, prowadzenie wspólnej przetwórni i warsztatów czy też wspólne użytkowanie specjalistycznych narzędzi i maszyn. Wedle słów założycieli, koncepcja Eko-Centrum Zelów kieruje się $w$ stronę wykreowania kompleksowej instytucji wspierającej, integrującej, w której rolnicy otrzymają wszelka pomoc.

Założyciele Stowarzyszenia wykazali się dużą sprawnością w zakresie organizacyjnym i pozyskiwania funduszy. Wzięli udział w szkoleniu dotyczącym podstaw marketingu rolnego i wygrali konkurs, uzyskując wsparcie Narodowego Banku Polskiego, Fundacji Bankowej im. Kronenberga, Fundacji Rozwoju Gminy Zelów oraz Urzędu Miasta Zelowa. Rolnicy uruchomili również projekt rozwoju agroturystyki "Eko-Kociszew" - wioska agroturystyczna, myśląc o uzupełnianiu dochodów z produkcji ekologicznej agroturystyką. Prezes Stowarzyszenia Zbigniew Bednarek zdobył wiedzę z zakresu marketingu produktów rolnictwa ekologicznego i widzi potrzebę sprzedaży na eksport, bo konfitury leżą zagranica. Elementem tej szerszej strategii było stworzenie profesjonalnej strony internetowej $\mathrm{w}$ polskiej i angielskiej wersji językowej, budowa strony została dofinansowana $\mathrm{w}$ ramach programu e-Vita ze środków Polsko Amerykańskiej Fundacji Wolności. Zainteresowanie polską produkcją ekologiczną okazało się znaczące, do Eko-Centrum ciągle zgłaszają się zagraniczni nabywcy. Niemniej, Bednarek ma świadomość, że sam jako producent mleka nie jest atrakcyjnym partnerem dla zagranicznych kontrahentów:

Rynek krajowy jest obiecujacy, ale konfitury leża zagranica. A zagranica to sq tiry. Nikt nie będzie rozmawial, nikt nie przyjedzie z Niemiec kupić dwie skrzynki mleka, czy 20 litrów. Ale 20 tysięcy czy 200 tysięcy? Podobnie nikt nie przyjedzie kupić 2 tony żyta, ale 20 ton czy 40 ton, tyle, ile można na tira załadować, to już jest oferta handlowa. A to sq znowu poważni odbiorcy, a to sq znowu wysokie ceny. (...) I bo do tego jest potrzebna grupa ludzi. Tym bardziej, bo specyfika rolnictwa ekologicznego sa małe gospodarstwa, nieduże. Stowarzyszenie po to powstato - to jest narzędzie tylko - po to powstało by zbierać te oferty. To jest socjologicznie, socjotechniczne bardzo trudne, z mentalnościa naszych rolników. Natomiast jest możliwe, że każdy zasieje 20 arów czegoś wspólnego, to się zbierze i będzie duża partia. Taki byt cel, żeby zebrać dużą grupę towarów. 
Dlatego podjął się pracy „misyjnej”, przekonując i skutecznie namawiając kilkunastu rolników z okolicy na przejście na metody ekologiczne, realizując idee stworzenia grupy producenckiej będącej główną ideą Stowarzyszenia. Bednarek i wspierający go rolnicy odwiedzili aż 46 wsi w gminie przekonując rolników do upraw ekologicznych. W przypadku Bednarka mamy do czynienia z zespoleniem jego własnego interesu ekonomicznego z misją ekologizacji Polski. Zwiększenie liczny gospodarstw rolniczych i integracja rolników służy zarówno poprawie jego sytuacji finansowej i rozwojowi biznesu, jak i moralnej sprawie produkcji żywności, która daje ludziom zdrowie $i$ silę.

W roku 2006 Bednarek zakończył 3-letni okres przestawiania się na uprawy ekologiczne i jego gospodarstwo jako pierwsze w powiecie bełchatowskim uzyskało certyfikat ekologiczny. Obecnie Bednarek dostarcza mleko do sklepów ekologicznych w Łodzi. Swą ideę biznesową wykłada następująco: Ponieważ mam niewiele ziemi to to jest wlaśnie mój pomyst na przetrwanie, czyli swego rodzaju ucieczka w jakość. Nie produkuje mleka po 78 groszy, tylko sprzedaje mleko po 3 zt, z papierkiem, $z$ atestem. Kilkoro jego kolegów jest w trzecim roku przestawiania, także w przyszłym roku Ekocentrum będzie mogło poszerzyć ofertę wobec sklepów ekologicznych, proponując m.in. mleko kozie czy warzywa. Bardzo ważnym owocem powstania Stowarzyszenia jest zorganizowanie systemu samopomocowego i zbiorowych zamówień w ramach struktur organizacji. Część rolników posiada bydło i sprzedaje po korzystnych cenach obornik kolegom zajmującym się uprawami zboża i warzyw, ci od zbóż odsprzedają następnie słomę hodowcom bydła. Ze względu na bliskość gospodarstw i wzajemność transakcji, zakup niezbędnych surowców okazuje się bardziej opłacalny ekonomicznie. Ponadto, rolnicy ekologiczni są zobowiązani do zakupu certyfikowanego materiału nasiennego ze ściśle określonych źródeł. Składając zbiorowe zamówienie, zelowscy rolnicy obniżają wydatnie jego koszty.

Działając w Stowarzyszeniu rolnicy ekologiczni podjęli wspólną walkę o korzystniejsze warunki prowadzenia działalności. Wspólnie wystosowali listy do Ministra Rolnictwa i burmistrza Zelowa o pozwolenie na legalną sprzedaż na targach i w lokalnych sklepach mleka niepasteryzowanego i jego przetworów (argumentując, iż zakaz sprzedaży mleka niepasteryzowanego i jego przetworów jest $w$ konflikcie z przepisami UE) oraz własnych, przetworzonych w warunkach domowych, produktów rolnych bez konieczności spetnienia wygórowanych, dostosowanych do 
wielkich przetwórni przepisów. W efekcie udało im się zdobyć zgodę burmistrza na organizację miejsc sprzedaży żywności tradycyjnej i ekologicznej.

W przypadku zelowskiego Eko-Centrum można zaobserwować, jak ważną role pełni pomysłowy, charyzmatyczny i wyposażony $\mathrm{w}$ wiedze i kompetencje lider. Rozmawiałem z czteroma rolnikami z okolic Zelowa, którzy przyznali, iż to dzięki inicjatywie oraz entuzjazmowi Bednarka zdecydowali się przejść na metody ekologiczne.

5.3 Klastry - ku rolnictwu ekspercko-ekologicznemu? Fenomen Doliny Ekologicznej Żywności

Klaster (ang. cluster) to znajdująca się $w$ geograficznym sasiedztwie grupa przedsiębiorstw $i$ powiązanych $z$ nimi instytucji zajmujących się określonq dziedzina, polaczona podobieństwami $i$ wzajemnie się uzupetniająca (www.klastry.pl). Istotą klastra jest integracja skupionych na jednym obszarze producentów (surowce pierwotne, przetwórcy), instytucji i organizacji, których łączy wspólna branża i wizja. Wedle definicji jest to przestrzenna koncentracja przedsiębiorstw, instytucji $i$ organizacji wzajemnie powiązanych rozbudowanq sieciq relacji o formalnym jak i nieformalnym charakterze opartych o wspólnq trajektorię rozwoju, czyli np. technologicznq, wspólne rynki docelowe (www.klastry.pl). Twórcy klastrów przewidują, iż rozwój klastrów będzie następował tak za pomocą interakcyjności powiązań, będzie efektem dynamiki zarówno rywalizacji, jak i współpracy współtworzących go podmiotów. Klastry tradycyjnie były utożsamiane $\mathrm{z}$ dystryktami przemysłowymi, takimi jak kalifornijska Dolina Krzemowa czy włoskie regiony produkujące buty czy odzież. Obecnie definicja ta uległa rozszerzeniu i obejmuje wszelkiego rodzaju produkcje, także rolnictwa ekologicznego.

W wypadku Doliny Ekologicznej Żywności, mamy do czynienia z organizacją o charakterze eksperckim, mającą się zajmować rozwojem rolnictwa ekologicznego. Marketingowy charakter projektu uwidacznia się w pozornym paradoksie samej nazwy, bowiem z geograficznego punktu widzenia chodzi o obszar wyżyny Lubelskiej, lecz twórcy projektu zdecydowali się nazwać go w ten sposób ze względu na kapitał symboliczny słowa Dolina, budzącego skojarzenia z Doliną Krzemową. Koordynacji projektu podjął się kanclerz prywatnej uczelni - Wyższej Szkoły Przedsiębiorczości 
i Administracji w Lublinie. Powołano zespół profesjonalistów ze stanowiskami eksperta ds. strategii promocji czy eksperta ds. promocji i PR projektu. Naukowcy skupieni w eksperckim zespole wypracowali strategię rozwoju projektu klastru obejmującą 150 stron. Na realizację projektu pozyskano dofinansowanie z funduszy strukturalnych UE. W myśl strategii, Dolina Ekologicznej Żywności stanie się klastrem klastrów, siecią współpracy i koordynacji grup producenckich z różnych obszarów rolnictwa.

W wypadku Doliny Ekologicznej Żywności, mamy do czynienia z organizacją o charakterze eksperckim, mającą się zajmować rozwojem rolnictwa ekologicznego i kreującą od podstaw organizacje mające ów klaster tworzyć. Równocześnie powołano do życia Stowarzyszenie Ekolubelszczyzna, mające stanowić jądro klastra. Jak zapowiada prezeska Stowarzyszenia, dr inż. Barbara Szymoniuk z Katedry Marketingu Politechniki Lubelskiej, będzie to sieć wspótpracy kilkuset różnych jednostek: rolników, producentów, sieci sklepów z naturalną żywnością, organizacji działajacych na rzecz rozwoju wsi, organizacji propagujacych zdrowy tryb życia, a także szkót wyższych i instytucji naukowo badawczych. Celem jest pobudzenie naszego regionu $w$ sferze produkcji żywności naturalnej (www.dolinaeko.lublin.pl). Lubelscy specjaliści od marketingu uznali, że aby dotrzeć do szerszych rzesz klientów przekonują, iż żywność naturalna jest smaczna i petnowartościowa, chcąc uniknąć skojarzeń z wegetarianami i dietetykami - grupami uważanymi za tradycyjnych odbiorców żywności ekologicznej. Wedle deklaracji strategów, projekt strategii Doliny Ekologicznej Żywności ma charakter otwarty, co oznacza, że w jej tworzeniu mogą brać udział organizacje, przedsiębiorstwa oraz osoby prywatne zainteresowane rozwojem rolnictwa ekologicznego, szeroko rozumiani interesariusze. Pierwszy etap rozwoju klastra ma obejmować zacieśnienia współpracy najważniejszych instytucji regionu aktywnych $i$ doświadczonych $w$ dziedzinie produkcji ekologicznej żywności, innowacji $i$ transferu technologii, $w$ tym władz samorządowych, ośrodków naukowo-badawczych, organizacji biznesowych $i$ przedstawicieli producentów (www.dolinaeko.lublin.pl). Strategia Doliny Ekologicznej Żywności jest pomyślana jako baza dla kolejnych, bardziej szczegółowych projektów i ma stanowić ogólne ramy strukturalne.

Słabą stroną lubelskiego projektu wydaje się zbyt mały udział samych rolników ekologicznych w jego formułowaniu. Sama strona organizacji i strategia są spisane w trudno zrozumiałym dla nich języku pełnym abstrakcyjnych terminów 
charakterystycznych dla żargonu nauk o zarządzaniu i marketingu oraz dyskursu wokół funduszy europejskich. W projekcie za mało jest konkretów, a za dużo enigmatycznych sformułowań w rodzaju: Udział $w$ realizacji projektu będzie polegat głównie na wsparciu intelektualnym i rzeczowo-technicznym poprzez uczestnictwo $w$ konsultacjach spolecznych $i$ zaangażowanie $w$ prace związane z kreacją Doliny Ekologicznej Żywności.

Idea klastrów staje się coraz bardziej popularną w Polsce także w obszarze produkcji żywności naturalnymi metodami, istnieje profesjonalny serwis internetowy www.klastry.pl, który propaguje organizację klastrów jako stymulatora rozwoju. Zelowscy rolnicy skupieni w Eko-Centrum wraz z ekspertami z Wydziału Zarządzania Uniwersytetu Łódzkiego próbowali przygotować projekt rozwoju rolnictwa ekologicznego w oparciu o idee klastra, jednakże pomysł na razie porzucono ze względu na zbyt małą liczbę producentów i przetwórców. Przyszłość pokaże, czy szeroko zakrojony i racjonalnie skonstruowany lubelski projekt marketingowy okaże się sukcesem. Projekt ten jest o tyle ważny, gdyż niesie duży potencjał ekspansji rynku żywności ekologicznej, pozyskania klientów nie-motywowanych ideologicznie lub zdrowotnie, projekt ten ma potencjał obniżenia cen żywności naturalnej. Myślę, że z dużym prawdopodobieństwem można przyjąć, że w najbliższych latach będziemy mieć do czynienia $\mathrm{z}$ większą ilością prób budowy klastrów zorientowanych na ekologiczną żywność.

\section{Ideologia eko-rolnictuva.}

Pojęcie ideologii zawiera $\mathrm{w}$ sobie obecnie negatywny aspekt wartościujący i dlatego wielu eko-rolników zaprzeczało jakoby posiadało jakąś ideologię. Amerykański antropolog Clifford Geertz (2005) krytycznie relacjonując obecne w naukach społecznych i mowie potocznej pojęcie ideologii, ujął je następująco: ideologia nie jest (dokładnie) tym samym, co kłamstwo, ponieważ kłamca zdobywa się przynajmniej na cynizm, a ideolog pozostaje jedynie ghupcem (s. 228). Geertz (ibidem) wskazal, iż powszechnie stosuje się obecnie znany wszystkim, ocierający się o parodie paradygmat: "Ja mam filozofię spoleczna; ty masz opinie polityczne; a on ma ideologię" (s. 225).

Chciałbym zaznaczyć, że $\mathrm{w}$ tym wypadku pisząc o ideologii rolnictwa ekologicznego nie rozumiem ideologii w sposób pejoratywny jako mieszaniny 
propagandy i kłamstw, rodzaj zaślepienia umysłu i darzę dużym szacunkiem osoby, które uznaję za głównych ideologów polskiego rolnictwa ekologicznego. Postrzegam ideologię jako konieczny element każdego ruchu społecznego, zawierający określoną wizje, sprecyzowane wartości, cele i kierunek, w jakim dany ruch ma zmierzać. Ruchy społeczne, zarówno te zorientowane na zmianę społeczną, jak i te dążącego do zapobieganie owej zmianie, $\mathrm{z}$ konieczności są ukierunkowane na realizację określonych idei, które łącznie tworzą mniej lub bardziej spójny system, który określiłbym mianem ideologii. Jestem przeciwny ograniczaniu pojęcia ideologii do przypadków kłamliwych i nienawistnych ideologii totalitarnych, w istocie każda organizacja społeczna posiada pewną ideologię, lepiej żeby owa ideologia była uświadomiona.

\subsection{Mieczystaw Górny jako ojciec polskiego rolnictwa ekologicznego}

Profesor Mieczysław Górny (1929-2005) był twórcą pierwszej w Polsce placówki naukowej zajmującej się eko-rolnictwem - Zakładu Ekologicznych Metod Produkcji Żywności w warszawskiej Szkole Głównej Gospodarstwa Wiejskiego i animatorem powstania ruchu społecznego eko-rolników. Górny ujmował rolnictwo w sposób holistyczny, nie był tylko technicznym specjalistą od eko-rolniczego knowhow, nie stronił od humanistyczno-religijnej refleksji o powołaniu człowieka, która zapewniła mu rolę duchowego lidera rolników ekologicznych. Redaktor Eko Arki, Zbigniew Przybylak (2005a) określił Górnego mianem człowieka wielkiego franciszkańskiego ducha. W rozdziale poświęconym procesowi stawania się rolnikiem ekologicznym zamieściłem kilka rolniczych świadectw ekologicznej konwersji, dokonanych pod wpływem siły charyzmy i argumentów profesora Górnego. Dla prof. Górnego rolnictwo należało umiejscowić w szerszym kontekście duchowo-moralnym, problemy techniczne miały swoje korzenie $\mathrm{w}$ niewłaściwych sposobach myśleniach, dlatego proponował nową filozofię rolnictwa. W wywiadzie dla Eko Arki zdobył się na osobiste wyznanie:

Zawsze uważałem, że wiele błędów wspótczesnego rolnictwa wynika z (braku -przyp. PB) glębszej refleksji duchowej na temat stosunku czlowieka do przyrody i nieprzestrzegania praw zawartych $w$ chrześcijańskim dekalogu. Etyka, a także religia porządkuje aktywność czlowieka, harmonizuje jego relacje ze światem przyrody, zwierzętami, cała przyroda, nadaje sens pracy (Eko Arka 2005b: 33). 
Profesor Górny uznawał, iż człowiek powołany jest przez Boga do dbałości o własne środowisko, przypominał słynne motto ekologów myśl globalnie, działaj lokalnie: jeżeli pragniemy szerzyć dobro, do którego czlowiek jest zobowiązany, powolany przez Boga, to uważam, że każdy powinien działać wokół siebie. $Z$ tych małych działań powinna dopiero powstać sprawa globalna (Eko Arka, ibidem). Jego zdaniem, rolnicy ekologiczni czynią dobro, gdyż ratują życie, dbają o godność całego stworzenia. Profesor Górny otwarcie mówił o roli Opatrzności w jego życiu, która kieruje nim, podobnie jak wszystkimi ludźmi chcącymi czynić dobro:

Podobnie bylo wcześniej $w$ Instytucie Badawczym Leśnictwa. Gdy przeciwstawitem się sztucznemu nawożeniu lasów, uważając je za szkodliwe, wypowiedziano mi pracę. Ale Opatrzność nade mna czuwała. Za pierwszym razem zaproponowano mi prace na SGGW. Za drugim razem $w$ tym samym dniu, kiedy dostatem wypowiedzenie zaproponowano mi prace na tej samej uczelni, w katedrze żywienia. Sprawdziła się więc po raz kolejny dewiza którq wyznaje i do której zachęcam innych także, $w$ tym studentów, których cały czas uczę - jak w życiu czlowiek bardzo pragnie robić coś dobrego, to są gdzieś $w$ Niebie sity, które będa nad nim czuwaty (Eko Arka ibidem).

W książce Ekorozwój wsi i rolnictwa prof. Górny (2002) wyjaśnia, co konkretnie rozumial przez dobro:

Dobro, to znaczy wlaściwy stosunek do świata i do ludzi. Wtaściwy znaczy taki, który jest korzystny nie tylko dla czlowieka, ale i dla innych istot. Aby dobro stało się rzeczywistościa, czlowiek musi dażyć do jak najlepszego zrozumienia tajemnic życia i musi to życie chronić. Nie tylko dlatego, że inne organizmy sq mu potrzebne, lecz dlatego, że istnieja. Oto wspótczesna zasada ochrony przyrody: chronić życie dla niego samego, dlatego, że jest, że istnieje (s. 33, podkr.PB).

Podobnie jak twórcy eko-filozofii Arne Naess czy Henryk Skolimowski, Górny postulował etykę biocentryczną jako remedium na słabości antropocentrycznej etyki. W myśl etyki biocentrycznej, przyroda i wszystkie żywe organizmy mają swoją autonomiczną wartość, niezależnie od ich przydatności dla człowieka. Górny sprzeciwiał się zdecydowanie przemysłowemu chowowi zwierząt czy laboratoryjnym eksperymentom na zwierzętach.

W pismach Górnego uwidacznia się wielka wrażliwość na ból i cierpienie zwierząt. 
Bardzo istotny jest jego humanistyczny protest wobec technologizacji zarówno rolnictwa, jak i dyskursu o rolnictwie. Górny (2002) postrzegał zakorzenienie problemu w samym języku nauk rolnych:

To $w$ laboratoriach opracowujacy sposoby chowu $i$ hodowli zwierzat gospodarskich wymyślili takie określenia jak "technologia produkcji żywca wieprzowego" (zamiast chowu świń) lub "remont stada" (zamiast selekcji hodowlanej). Czy sa to tylko stowa? Nie, jest to wyraz niewłaściwego, nieetycznego stosunku człowieka do zwierząt. Cóż powiedzieć o temacie pracy habilitacyjnej, która została przedstawiona $w$ uznanym $w$ Polsce instytucie Polskiej Akademii Nauk, $w$ której przedmiotem badań byt: "Kat bydlęcy jako sktadnik dawek pokarmowych dla mtodego bydta opasowego" (s. 152).

Podstawowe przesłanie Górnego sprowadzało się do konstatacji, iż gospodarstwo nie jest fabryką, a żywe zwierzę wyposażone w świadomość zwyczajnym surowcem produkcyjnym. Krytykowani przezeń technokraci dążyli do osiągnięcia znieczulenia na ból zwierząt poprzez ich reifikację. Górny zwrócił uwagę na alienację świata nauki rolniczej od świata etyki i życia potocznego. Zwykły rolnik nie zmuszałby krowy do jedzenia własnego kału, lecz praktyka taka okazuje się być technologiczną innowacją promowaną w pracy habilitacyjnej eksperta z Instytutu Genetyki i Hodowli Zwierząt PAN. Redukcjonizm współczesnej nauki pozwala, aby w strukturze Polskiej Akademii Nauk istniała placówka badająca zagadnienia życia codziennego z perspektywy etycznej, lecz inne wydziały tej instytucji zostały oddane technokratom zwolnionym od wszelkich trosk natury moralnej. Moralne oburzenie względem praktyk karmienia bydła kałem, jak i mówienie w wywiadach o swoich krowach czy krówkach, świniach lub świnkach, a nie o żywcach lub opasach świadczy o moralnym i życzliwym stosunku eko-rolników wobec zwierząt. Ekologizacja rolnictwa idzie w parze z humanizacją rolnictwa.

6.2 Zbigniew Przybylak i kwartalnik Eko Arka - między praktycznością a mistycyzmem

Zbigniew Przybylak jest wydawcą i redaktorem naczelnym prawdopodobnie najważniejszego organu prasowego polskich rolników ekologicznych - wychodzącej w Bydgoszczy Eko Arki, kwartalnika powstającego przy współpracy rolników Oddziału Kujawsko - Pomorskiego Stowarzyszenia "EKOLAND". Ów magazyn określa się programowo jako praktyczne specjalistyczne czasopismo ekologiczne dla 
rolników, ogrodników i konsumentów, które ukazuje się zgodnie z porami roku $w$ miesiacach: marzec, czerwiec, wrzesień i grudzień (Eko Arka 1/2006: 1, podkr. PB). Dysponując nakładem od 1500 do 2000 sztuk, Eko Arka zasługuje na miano najbardziej poczytnego specjalistycznego pisma rolników ekologicznych. W toku badań okazało się, że jest to jedyne znane eko- rolnikom niezależne czasopismo poświęcone niemal wyłącznie sprawom rolnictwa ekologicznego. Przybylak ponadto, co roku wydaje kalendarz księżycowy dla rolników, ogrodników, wędkarzy i zielarzy, w którym można sprawdzić, w jakiej fazie aktualnie znajduje się księżyc i czy dzień sprzyja siewom lub zbiorom.

Cechą charakterystyczną Eko Arki jest jej familijny charakter, czasopismo jest bowiem tworzone przez jedną rodzinę. Najwięcej artykułów pisze osobiście Zbigniew Przybylak, a część artykułów pisze jego syn Karol i jego córka Magdalena PrzybylakZdanowicz, zdjęcia do gazety robi z kolei Tomasz Zdanowicz. Jedynie okazjonalnie pojawiają się artykuły innych autorów, mając najczęściej charakter fachowych opracowań.

Eko Arka charakteryzuje się prostym, konkretnym językiem, którym autor posługuje się prawdopodobnie intencjonalnie celem dotarcia do rolników. Przykładowe tytuły artykułów to Krowy, konie i zboża, Od pomidorów, czosnku i mleka po maliny i ogórki, Ratowanie polskiej rasy bydta nizinno czarno-biatego (Eko Arka nr 1/2007), Wśród owoców i ziót, Wśród cebuli, marchwi i buraczków czy Truskawkowo-malinowa grupa (Eko Arka 3/2005), bądź Świnie w naturze i Kozi gródek (Eko Arka 3/2009). Każdy numer zachowuje standardową strukturę. Na okładce widzimy $\mathrm{w}$ tle jakieś zdjęcie krajobrazu związanego $\mathrm{z}$ rolnictwem ekologicznym (np. wiatrak, krowy na łące, porzeczkowe krzewy, wokół których rosną koniczyny), na którym w pionowym słupku widnieją cztery fotografie bohaterów artykułów danego numeru i ich rodzin zawsze z naturalnym tlem

Standardowo, czasopismo zamieszcza także kilka historii różnych gospodarstw ekologicznych z licznymi zdjęciami. Można w nich przeczytać o ideach, konkretnych technikach i praktykach rolniczych opisanych w języku trudno zrozumiałym dla nierolników, na końcu zawsze podany jest kontakt do prezentowanego gospodarza. Ponadto magazyn zawiera prezentacje wybranych roślin, przepisy na zdrowe potrawy diety ekologicznej, zapowiedzi i relacje z imprez i wydarzeń związanych z rolnictwem ekologicznym (np. pielgrzymka, zawiązanie nowej organizacji, ekologiczne dożynki), krótkie recenzje książek. W piśmie występują też cykle wokół rożnych aspektów 
ekologii i naturopatii, np. Kosmetyki z warzyw, czy Jak chronić pożyteczne owady? Wielu z badanych przeze mnie eko-rolników czyta regularnie Eko Arkę i chwali ten magazyn za fachowe, praktyczne porady. Jednakże, Eko Arka oprócz swego praktycznego oblicza, ma silny wymiar ideologiczny, o którym moi rozmówcy raczej nie wspominali, lub wymieniali jedynie propagowanie katolicyzmu.

Przybylak nie ukrywa, iż jest praktykującym katolikiem, w jego tekstach znajdują się odwołania do Boga, a jako synonim rolnictwa ekologicznego stosuje termin Boże rolnictwo. Syntezę kategorii ekologiczności i boskości przynosi jego broszura zatytułowana Nasze Boże rolnictwo ekologiczne. Przybylak (2007c) chętnie utożsamia rolnictwo ekologiczne z tradycyjnym rolnictwem, gdzie praca i modlitwa - zarówno blagalna jak i dziękczynna za wstawiennictwem Matki Bożej - cały czas się splataja (s. 1). Prezentując eko-gospodarstwa i sylwetki rolników od strony praktycznej, Przybylak chętnie podkreśla znaczenie wiary $\mathrm{w}$ Boga $\mathrm{w}$ ich życiu. Przykładowa narracja zaczyna się w następujący sposób:

Damian Nowak zdecydowat się wesprzeć i przejąć ekologiczne gospodarstwo po ojcu. Jest bardzo zadowolony z tej decyzji. Patrzy z nadzieja $w$ przyszłość. Wierzy, że z Boża pomoca poradzi sobie $i$ zdobędzie kolejnych klientów na oferowane przez siebie produkty od chleba, rogalików, pomidorów i jajek poczqwszy, na warzywach, mleku, maśle, serach skończywszy (Przybylak 2006c: 2).

Przybylak jest również animatorem corocznych pielgrzymek rolników ekologicznych do Częstochowy. Ów bydgoski dziennikarz cieszy się świetnymi relacjami z Kościołem, ojciec Marian Lubelski określił go w mowie powitalnej mianem brata Zbigniewa. Przybylak również chętnie oddaje się rozważaniom mistycznym, w czasie częstochowskich nabożeństw dzielił się swymi przeżyciami duchowymi z pielgrzymki do Medziugorie, gdzie na górę wniósł kamień w intencji rolnictwa ekologicznego.

Miałem okazję wziąć udział w ostatniej - trzeciej - edycji pielgrzymki 25 listopada 2006 roku, w której uczestniczyło blisko 400 rolników i sympatyków eko-rolnictwa. Rolnicy złożyli ślubowanie zawierzenia się Matce Bożej Jasnogórskiej - królowej Polski, zobowiązując się by $w$ sercu stużyć obronie świętości wszelkiego życia u samych jego źródel, gospodarując $i$ żyjąc ekologicznie $w$ duchu świętego Franciszka, patrona ekologów. Ojciec Marian Lubelski, przeor klasztoru paulinów, nazwany przez Zbigniewa Przybylaka mianem duchowego przewodnika rolnictwa ekologicznego $\mathrm{w}$ swej homilii łączył idee ekologiczne $\mathrm{z}$ patriotycznymi: rolnicy 
ekologiczni w sposób naturalny uprawiaja ziemię, aby żywić polski naród; nie truć, nie szkodzić, ale dawać zdrowy pokarm. Przybyli z całej Polski rolnicy złożyli w darze Matce Boskiej chleb i kamień, jako symbole trwatości i wartości rolnictwa ekologicznego, także dziękczynienia $i$ dobra. W trakcie uroczystości zawiązano wspólnotę modlitewną rolników ekologicznych Kamień $i$ Chleb. Wedle relacji kwartalnika Eko Arka, na koniec Eucharystii rolnicy zawierzyli siebie, swe rodziny, swa prace $i$ całe rolnictwo ekologiczne Najświętszemu Sercu Pana Jezusa i Niepokalanemu Sercu Maryi przez ręce Matki Bożej Jasnogórskiej Królowej Polski (Przybylak - Zdanowicz 2007:31-32). Ceremonia obejmowała tradycyjne rytuały wspólnotowe: poświęcenie przywiezionych przez rolników chlebów i ciast i śpiewy w kręgu. Miało miejsce również święcenie symboli Bożego rolnictwa - zielonych różańców i Cudownych Medalików, te ostatnie, zdaniem brata Stefana z Niepokolanowa, są obdarzone cudowną mocą. Ów brat opowiedział zebranym, iż cudem ocalał z wypadku przywalony autokarem, jego habit miał być porwany, a ocaleć jedynie kieszeń, w której znajdowały się owe medaliki. W czasie świadectw rolników jeden z uczestników ofiarował organizatorom spotkania obraz Matki Boskiej Chorzelewskiej Królowej Rodzin z Chorzelewa, położonego w pobliżu Mielca, aby stała się ona patronka wszystkich rodzin ekologicznych. Jak relacjonuje w Eko Arce Magdalena Przybylak - Zdanowicz (ibidem): po złożeniu modlitewnych intencji, wszyscy wyciszyli się $w$ trakcie rozmyślania, modlitwy kontemplacyjnej III tajemnicy chwalebnej Różańca świętego Zestanie Ducha Świętego przed obrazem Pana Jezusa Miłosiernego z charakterystycznym ekologicznym ttem, stanowiacym krajobraz polski( s. 31-32).

W Eko Arce znajdujemy często cytaty z Jana Pawła II, Benedykta XVI, ojca Pio czy świętego Franciszka. Ideologię Eko Arki na pierwszy rzut oka można by określić jako franciszkańsko-ekologiczną, jednakże poglądy Przybylaka wyrażane w jego publikacjach, takich jak książka Stawne proroctwa, objawienia, przepowiednie dla Polski i świata na XXI wiek, wymagają głębszej analizy, gdyż w nich najwyraźniej ukazuje się mesjanistyczna misja, jaką Przybylak przydziela rolnictwu ekologicznemu.

We wspomnianej publikacji ów znany animator eko-rolnictwa dokonuje swoistej syntezy mesjanistycznych aspektów filozofii polskich romantyków (Mickiewicza, Krasińskiego, Słowackiego, Norwida) ze świadectwami lub fragmentami kazań czołowych postaci polskiego Kościoła (m.in. kardynała Augusta Hlonda, kard. Wyszyńskiego, św. Faustyny Kowalskiej, Jana Pawła II) by uzupełnić je o analizę 
tajemnic fatimskich przepowiedni i świadectw ojca Pio. Wszystkie te źródła skłaniają go ku postawieniu tezy o zbliżającym się kataklizmie, boskiej karze dla materialistycznej zachodniej cywilizacji i wynikającego stąd mesjanistycznego posłannictwa Polski, a zwłaszcza polskiej wsi. Jako znamiona zagrożeń apokaliptycznych, Przybylak (2003) wymienia totalny ekonomiczny, kulturowy globalizm i potaczony z nim wielki, nigdy niespotykany $w$ dziejach, wyzysk państw przez państwa i ludzi przez ludzi czy bardzo zmaterializowany, konsumpcyjny, przyjemnościowy i nie stawiający na pierwszym miejscu praw natury i praw bożych zachodnioeuropejski i zamerykanizowany liberalny model cywilizacyjny (s. 9-10). Mamy tu do czynienia z całościową dezaprobatą wobec procesów przemian społecznych, gospodarczych i kulturalnych zachodzących w rozwiniętym świecie. Przybylak (ibidem) podziela właściwe konserwatywnej prawicy zgorszenie rozluźnieniem norm i obyczajów, domaga się całkowitego zakazu aborcji, łącząc swój konserwatyzm zantyglobalistyczną krytyką polaryzacji dysproporcji rozwojowych i właściwym dla ruchu ekologicznego oburzenia wobec ogromnego, nigdy niespotykanego $w$ dziejach ludzkości, zniszczenia środowiska rolniczego iprzyrodniczego, wyginięcia wielu gatunków i ras zwierząt dzikich oraz gospodarskich, zatrucia wód, powietrza, żywności, szerzenia się chorób, epidemii, wyczerpywania się zasobów (s. 10).

Przybylak (ibidem) w swej katastroficznej wizji stwierdza, iż szczególnie zagrożone musza się czuć Stany Zjednoczone i cała Ameryka Pótnocna, $w$ dalszej kolejności Zachodnia Europa. W kwestii działań prewencyjnych, dysponuje konkretną wskazówką: przetrwanie gwarantuje tylko duch $i$ proste metody gospodarowania (s. 234-235). Pomimo wrażenia katastrofizmu, Przybylak (ibidem) pragnie określić się jako katastrofistę optymistycznego, gdyż wierzy, iż wszystko, co Opatrzność nam gotuje, ma glęboki sens - zaś ewentualna katastrofa byłaby laska Boża powstrzymująca ludzka pychę. Ponadto, odwołując się zarówno do argumentów irracjonalnych, takich jak przepowiednie znanego jasnowidza i zielarza ojca Czesława Klimuszki (Nad Polskq bowiem nie widzę ciężkich chmur, lecz promienne blaski przyszłości...), jak i racjonalnych argumentów, stawia on tezę, iż w czekającym ludzkość dziejowym kataklizmie Polska ucierpi mniej (s. 12-13 i 166170). Konkretnie bydgoski dziennikarz swe nadzieje pokłada $w$ polskiej duchowości $w$ ujęciu religijnym, a zwłaszcza polskiej wsi: jest to fundament, na którym można odbudować wszystko (Przybylak ibidem: 235). 
Przybylak dokonuje adaptacji właściwej ekologom idei leapfroging, czyli uczynienia z zacofania kraju silnego atutu, umożliwiającego stworzenie "na skróty" zielonej, niskoenergochłonnej gospodarki, opartej w znacznej mierze o naturalne źródła energii, omijając etap intensywnej industrializacji, z którego wychodzą kraje Zachodu. Wedle Przybylaka (ibidem), nasze zacofanie może być naszq szansą: bardzo ekologiczna, rozdrobniona struktura polskich gospodarstw rolnych, stosujacych jeszcze dosyć proste metody hodowli i uprawy, która powszechnie określa się - niestusznie i tendencyjnie - mianem zacofanej, ale która $w$ czasie światowego chaosu, może nadal, $w$ miarę sprawnie funkcjonować $i$ dostarczać żywność (s. 13). Przykładowo, nowy kryzys paliwowy może spowodować, że kraje gdzie rolnictwo jest w pełni zmechanizowane nie będą w stanie wytwarzać żywności, w przypadku polskiego rolnictwa zacofanego i ekologicznego jakoś sobie poradzimy (np. ręczne pielenie, użycie koni). Przybylak (2009a) nazywając gospodarstwa ekologiczne szalupami antykryzysowymi wprost pisze, że szalupa jest większa i solidniejsza, gdy rolnik na dodatek sam sprzedaje swój towar odbiorcom i np. postuguje się prostymi narzędziami i maszynami. Można określić Przybylaka jako antyglobalistę, gdyż głosząc potrzebę eliminacji pośredników w handlu, jednocześnie uznaje on, że eko-gospodarstwo jest tym lepiej przygotowane, im mniej jest uzależnione od krajowej i światowej gospodarki (s. 1).

Polska ze swym katolicyzmem ludowym przesiąkniętym maryjną duchowością ma, wedle Przybylaka, szansę wskazania całemu światu właściwej boskiej drogi szacunku dla Boga, przyrody i człowieka. Przybylak (ibidem) posiłkuje się takimi dowodami jak objawiona św. Faustynie Kowalskiej rzekoma wypowiedź Chrystusa, iż Polskę szczególnie umitowatem, a jeżeli postuszna będzie mej woli, wywyższe ja $w$ potędze i świętości. $Z$ niej wyjdzie iskra, która przygotuje świat na ostateczne przyjście moje (s. 5).

Tytuł omawianego magazynu wprost nawiązuje do biblijnego symbolu Arki Noego, mającej uratować z potopu szlachetnie żyjącą część żywych istot, aby zawrzeć nowe przymierze z Bogiem. W felietonie "Ekologia pokoju z EKO ARKI" Przybylak kreśli parabolę między gospodarstwami ekologicznymi a ideą nowego przymierza:

Każde gospodarstwo ekologiczne poprzez swa dziatalność na rzecz uzdrawiania zdrowia ludzi $i$ zwierząt, ale też uzdrawiania przyrody, świata roślin, a także wód, powietrza, krajobrazu staje się swego rodzaju EKO ARKA ograniczająca lęk, strach, niepokój i budująca wzajemne zaufanie, pokój między ludźmi i stworzeniami, 
cała przyroda. Ta dziatalność gdy wyptywa z miłości stuży także uświęcaniu relacji między ludźmi, światem stworzonym i Bogiem. (...) Gospodarowanie ekologiczne poprzez swój szacunek do natury, samoograniczanie $w$ korzystaniu z zasobów naturalnych świata, poprzez swe etyczne Boże podejście do ludzi, świata stworzonego umożliwia petny rozwój nie tylko materialny, ale iduchowy czlowieka. Jednocześnie przez to stuży budowaniu pokoju lokalnego, ale też globalnego (Eko Arka 2007a: 1).

W tym krótkim fragmencie prowadzenie gospodarstwa ekologicznego zostaje uznane za szlachetną działalność służącą tworzeniu nowego społeczeństwa, opartą na odmiennych relacjach międzyludzkich, stosunku człowieka do przyrody i do Boga. Wśród walorów tych gospodarstw - zalążków nowego przymierza - Przybylak (ibidem) wymienia budowanie pokoju, zaufanie, szacunek, cześć dla Boga i przyrody, dbałość o duchowy rozwój człowieka. Mówiąc o Ekologicznym Bożym Rolnictwie i jego etycznym Bożym podejściu do ludzi $i$ świata stworzonego (ibidem) sugeruje implicite, iż świat rolnictwa konwencjonalnego cechuje się bezbożnym podejściem do człowieka i przyrody, a agrochemia to rodzaj grzechu.

W Eko-Arce pojawiają się idee charakterystyczne dla konserwatywnej prawicy, takie jak radykalny sprzeciw wobec aborcji czy swobody obyczajowej. Przybylak (2006b) lubi krytykować terroryzm politycznej poprawności i tworzyć analogię pomiędzy walkq o Prawdę $w$ sferze obyczaju (konserwatywna prawica) i walka o Prawdę $w$ sferze rolnictwa (eko-rolnictwo) (s. 1). W swym artykule wstępnym Największa Moc. Modlitwa z EKO ARKI, Przybylak (2006a) kreśli analogię pomiędzy aborcją a chemizacją rolnictwa. Odwołując się do postaci Jana Pawła II w cytowanym tekście pisze:

Modlac się o jego wsparcie z Nieba dla siebie, rodziny, spraw, którym stużę - przede wszystkim rozwojowi rolnictwa ekologicznego, które chroni życie u samych źródet, bo zapobiega aborcji na ziemi $i$ ludziach dokonywanej chemia, uprzemystowieniem rolnictwa i przetwórstwa żywności rozważałem, jakie zostawił On nam najważniejsze przesłanie. $W$ Kalwarii Zebrzydowskiej w 1979 roku mówit tak: "Niech z tego miejsca (...) przemówi proste i zasadnicze papieskie wezwanie do modlitwy. A jest to wezwanie najważniejsze, najistotniejsze orędzie" (s. 1, podkr.PB).

W tym fragmencie mamy do czynienia z ciekawym przykładem zabiegu retorycznego, Przybylak przywołał pojecie aborcji, termin niezwiązany bezpośrednio z tematem, lecz mający ogromny potencjał mobilizacji emocjonalnej większości wyznawców 
katolicyzmu. Tutaj potępiana przez Kościół Katolicki praktyka aborcji zostaje rozszerzona na obszary działalności rolnictwa konwencjonalnego: stosowanie środków chemicznych w produkcji rolnej. Przywołanie następnie postaci Jana Pawła II świadczy o walce o zasoby katolickiego uniwersum symbolicznego w ramach areny sporu społecznych światów rolnictwa ekologicznego z konwencjonalnym (Por. Berger, Luckmann 1983).

Gospodarstwa ekologiczne są określone przez Przybylaka jako Eko Arki życia. Tego typu terminy są silnie nacechowane emocjonalnie i pełnią funkcję perswazyjną. Przybylak (2006a) przekonuje czytelników, iż modlitwa ma moc sprawczą, również wpłaszczyźnie ekonomicznej: Odwiedzając liczne gospodarstwa ekologiczne dostrzegłem, że tam gdzie jest dużo modlitwy, wspótpracy z Bogiem, sa zazwyczaj dobre rezultaty gospodarowania, sq nadzieja, radość, spokój, zadowolenie, sq klienci (s. 1). Także w tym tekście Przybylak (ibidem) przywołuje budzące lęk zagrożenia, jakie niesie rozwój współczesnej techniki, takie jak genetycznie modyfikowana żywność i jako receptę wskazuje modlitwę oraz ludowy katolicyzm. Nie tudźmy się, że tylko ludzkq moca jesteśmy $w$ stanie te lęki i trudności przezwyciężyć, odzyskać pokój i radość w sercu. Dlatego wszyscy powinniśmy prosić o pomoc Boga, Jezusa, Maryję, Ducha Świętego, patrona ekologów świętego Franciszka i gorliwiej modlić się za siebie, sprawy, którym stużymy, za klientów itych, którzy działaja $w$ naszym imieniu. Modlić się trzeba również o sity do przezwyciężania zła dobrem (s. 1).

Wielu dobrych rolników ma lepsze wyniki ekonomiczne niż ich koledzy konwencjonalni - pisze Przybylak (2007b: 1), sugerując jednocześnie, że konwencjonalni rolnicy nie są „dobrzy” w sensie moralnym. Znamienna jest prosta, manichejska opozycja, jaką posługuje się ów propagator eko-rolnictwa. Siły przemysłowego rolnictwa i zwolennicy aborcji to zło, a eko-gospodarstwa i obrońcy życia to słudzy dobra, lecz zalecane przezeń metody walki mają raczej naturę pokojowo-mistyczną niż konfrontacyjną.

Podsumowując, Eko Arka ma dwa oblicza: czysto praktycznego poradnika informatora dla ekorolników oraz forum prezentacji idei wyznaczających ekorolnictwu misję moralną i religijną. Część ekorolników może być skupionych bardziej na praktycznym wymiarze czasopisma, lecz wielu z nich identyfikuje się również z projektem ideowym i podstawową opozycją podkreślaną przez Przybylaka: zdrowe - ekologiczne - boże - moralne kontra przemysłowe - chemizowane - 
bezbożne - amoralne. Najważniejszą ideologii Przybylaka jest zespolenie misji ekorolnictwa z polskim, tradycyjnym, maryjnym katolicyzmem, tworząc mesjanistyczne przesłanie o ważnej roli eko-gospodarstw, metaforycznych Arek Noego w ratowaniu świata przed destrukcją ekologiczną i materializmem.

\subsection{Rolnictwo ekologiczne - pomiędzy konserwatyzmem a high tech}

Stosunek do nowoczesnych technologii można by uznać za wskaźnik postawy rolników ekologicznych wobec modernizacji. W rzeczywistości rolnictwo ekologiczne ma zarówno swe konserwatywne, jak i nowoczesne oblicze. Konserwatyzm jest widoczny nie tylko $\mathrm{w}$ ideologii Eko Arki, zespalającym ludowy katolicyzm z mesjanistyczną ideologią bożego rolnictwa ekologicznego, lecz również w samej praktyce rolniczej - powrót do dawnych, pierwotnych technik stosowanych przed wkroczeniem $\mathrm{w}$ erę mechanizacji i chemizacji rolnictwa, jak i w promocji idei produktu tradycyjnego - szperaniu w przedwojennych receptach.

Postępowość jest widoczna we właściwej wielu rolnikom ekologicznym wierze w naukę oraz w szacunku, jakim darzą jej autorytet jak również w swoistym pociągu do ekologicznych nowinek technicznych. Nauka i technologia wszak to nie tylko budzące grozę genetyczne modyfikacje, ale również wiatraki, słoneczne panele fotowoltaiczne czy maszyny do pielenia, o których marzą niektórzy rolnicy ekologiczni. Kilkoro z badanych przez mnie rolników było zafascynowanych ideą EM - efektywnych mikroorganizmu, organicznego preparatu opracowanego przez japońskich naukowców, mającego doprowadzić do zrewolucjonizowania rolnictwa ekologicznego. Warto w tym kontekście przytoczyć wypowiedź jednego z rolników ekologicznych z łódzkiego. Zapytany przeze mnie o istotę rolnictwa ekologicznego, na pierwszym miejscu wymienił aspekt ekonomiczny, czyli nowa niszę rynkowa, by następnie wspomnieć moralna sprawę, że produkując zdrowa żywność, produkuje żywność, która daje ludziom zdrowie i siłę i tak dalej aby przejść do aspektu technologicznego - idei high tech.

A ja po prostu zobaczytem ta niszę rynkowa. I pomyślatem, że można na tym zarobić żeby przetrwać i mieć środki na inwestycje i tak dalej. I dochodzi też ta moralna sprawa, że produkując zdrowa żywność, produkuję żywność, która daje ludziom zdrowie i sitę i tak dalej. I to nie jest bez znaczenia, szczególnie, że rolnictwo ekologiczne to nie jest najtatwiejszy proces produkcji żywności. 
I dochodzi jeszcze, że rolnictwo ekologiczne to jest high tech, najnowsza technologia, gdzie tam genetyczne modyfikacje - to tam jest prymityw! Tu czlowiek, który jest tego świadom to może Pana Boga za nogi zlapać. Zrozumieć te wszystkie mechanizmy, które dziataja $w$ przyrodzie, poznaje się wszystkie zależności że jedne robale nie lubiq drugich, szczuje się jedne robale na drugie, i tak dalej. To jest high tech, to jest nowoczesna technologia. Poza tym sq nowoczesne środki produkcji, preparaty biologiczne, nawozy, kopaliny, stosuje się technologię EM, mikroorganizmy, mieszania różnych bakterii, które po prostu działaja jak mocny nawóz azotowy, a nie jest to sztuczne bo sa specjalnie ztapane i wyizolowane bakterie z tych, które sq, całkiem naturalne, to jest taka specjalna mieszanka, żadne genetyczne modyfikacje robaków, co żra plastik czy ropę. Czyli praktycznie to jest high tech, to jest najnowsza technologia.

W tej wypowiedzi rolnik ekologiczny jawi się nie jako chłop, co to ziemie uprawia, jak od dziada, pradziada się uprawiało, tylko dobrze obeznany z nowinkami nauki menedżer ekosystemów, alchemik zarządzania, inteligentny znawca wszystkich istotnych zależności $\mathrm{w}$ przyrodzie. U owego rolnika nie występuje postrzeganie sprzeczności pomiędzy misją a biznesem, pokorą wobec naturalnych procesów ekologicznych i ludzką zdolnością do zarządzania. Podejście to koresponduje z wyrażoną, zdradzającym podejście systemowe, definicją rolnictwa ekologicznego zaproponowaną przez propagatorkę tej metody Helenę Norberg-Hodge (2001):

Rolnictwo ekologiczne nie jest zwykta kolekcja technik, lecz catym systemem zarzadzania (management). Wszystkie komponenty tego systemu wzmacniaja się wzajemnie, pracując synergicznie nad zachowaniem zdrowego i produktywnego ekosystemu rolniczego. Sukces rolnictwa ekologicznego wymaga dokładnej znajomości lokalnych warunków $i$ docenienia silnych $i$ stabych stron konkretnego gospodarstwa. Ekologiczne metody zmierzaja do pracy $z$ naturalnym środowiskiem zamiast zdominowania jej, próbq harmonizacji kompleksowej sieci połaczonych procesów danego ekosystemu zamiast oczekiwania, aby system odpowiadat sztucznym normom (s. 64-65)

Inny rolnik w następujący sposób relacjonuje odkrycie słynnego japońskiego preparatu:

Jest pewna nadzieja. Pojawil się na horyzoncie taki preparat japońskiego producenta, który ożywia to życie, te mikroorganizmy glebowe. Bo teoria konwencjonalna, to jest ta chemiczna, polega na 
tym, że określamy zawartość N.P.K. w ziemi, azotu, potasu, wapnia..

Filozofia uprawy ziemi, roślin, gleby, ta ekologiczna polega na tym, że ziemia, $w$ ziemi istnieje tak zwane życie organiczne, po prostu życie, istnieje wiele drobnych organizmów, odpowiedzialnych za to by wykarmić roślinę $i$ ja bronić, jeśli tych mikroorganizmów jest mało, Pojawit się taki japoński preparat efektywne mikroorganizmy glebowe, który może być jakimś tam przełomem wrozwoju rolnictwa ekologicznego, że może ono zacząć rozwijać się na masowa skalę. Ale ja dopiero się $w$ tym roku o tym dowiedziatem, to jeszcze trzeba będzie sprawdzić. Jeśli producenci będa autentycznie mieli racje, że będzie można przetamać barierę tych pożytecznych mikroorganizmów, poprzez zastosowanie tego preparatu to to najprawdopodobniej będzie rewolucja $w$ rolnictwie ekologicznym. Ale to trzeba poczekać, sprawdzić, zobaczyć efekty, no nie?

Rolnicy ekologiczni są przede wszystkim empirykami. Mają nadzieje, iż nowe technologie będą sprzyjać rozwojowi upraw ekologicznym, lecz nie są łatwowierni, gdyż każdy nowy preparat musi przejść próbę ognia, być zastosowanym w praktyce. Dopóki sami nie zastosują owego preparatu, tak jak nie zastosowali w praktyce np. kalendarza księżycowego, nie mogą z przekonaniem go promować.

\section{Bariery rozwoju eko-rolnictwa}

Najczęściej wymienianą barierą jest oceniany jako nadmierny i zupełnie niepotrzebny rygoryzm polskich przepisów i praktyk kontrolerów od czasu wejścia Polski do Unii. Rolnicy, którzy mieli okazję pobytu w zagranicznych gospodarstwach konfrontują swe doświadczenia z zagranicy z polskimi i stwierdzają, iż to wcale nie winna jest Unia tylko polscy urzędnicy chcą być bardziej papiescy od papieża i interpretują przepisy w sposób uznawany przez eko-rolników za irracjonalny. Znamiennym przypadkiem jest przepis zezwalający tylko na trzymanie jednego gatunku zwierząt $\mathrm{w}$ jednym pomieszczeniu gospodarczym. Polscy kontrolerzy zmuszali rolników pod tym pretekstem do niszczenia gniazd jaskółczych. Przepis ten wyraża raczej ideę sterylności będącą obcą duchowi ekologii, opartej na symbiotycznych współzależnościach wielu gatunków. Łódzki rolnik relacjonuje: Bytem na kilku gospodarstwach $w$ Niemczech i tam razem trzymaja owce, krowy, kozy i na jaki brud oni sobie pozwalają! A u nas nie musi być czysto na błysk, kóz musiatem się wyzbyć by utrzymać bydło. 
Katalog skarg polskich eko-rolników przynosi opublikowana w Eko Arce nr 2/2006 Uchwała walnego zebrania członków Warmińsko-Mazurskiego Stowarzyszenia Producentów Żywności Ekologicznej EKOPOLSMAK z dnia 30.03.2006.

Uchwała zaczyna się od oskarżeń pod adresem firm certyfikujących, które zabiegaja przede wszystkim o wlasny interes, konkurując między sobą, wprowadzają brutalny element wolnego rynku również $w$ tej dziedzinie. Tak firmy certyfikujące, jak i ustawodawcy są odpowiedzialni za zbyt częste, zdaniem rolników, zmiany przepisów i rozporządzeń, utrudniających rolnikom działalność gospodarczą. Jeżeli chodzi o obecne przepisy, to warmińsko-mazurscy rolnicy żalili się na obarczenie rolników ekologicznych obowiązkiem dokumentowania pochodzenia materiału siewnego. Widzą w tym niesprawiedliwość, gdyż rolnicy konwencjonalni mogą brać ziarna $\mathrm{z}$ dowolnego źródła, mogąc zaopatrywać się $\mathrm{w}$ nasiona na zasadzie samopomocy sąsiedzkiej czy kupując je na targowiskach. Aby rolnicy ekologiczni mogli sobie przekazać nasiona muszą uzyskać zgodę stosownego organu w Warszawie. Szczególne trudności obowiązek dokumentowania pochodzenia nasion sprawia rolnikom specjalizującym się w dawnych gatunkach zbóż, owoców czy warzyw.

Czasami u rolników pojawiały się symptomy zmęczenia kontrolami, przekonanie, iż niezapowiedziane kontrole naruszają ich prywatność. Oto fragment wywiadu z eko-rolniczką z łódzkiego:

R. Ja $w$ zeszlym roku miałam raz, dwa, trzy razy ci, sześć, sześć kontroli, sześć razy byli u mnie i zagladali mi $w$ każdy kąt i sześć razy musiatem być do ich dyspozycji. Za co? To byt Bioekspert raz, Bioekspert rekontrola, robili, bo od czasu do czasu robia powtórne kontrole, więc pierwszy raz miatem powtórna kontrolę. Trzy razy byli z Agencji, no to taka dhuga nazwa, Inspekcja Jakości Handlowej Artykułów Rolno-Spożywczych, trzy razy byli. Szósty raz to była Orto-foto-mapa.

B. Nie styszatem o takich kontrolach...

$R$. To była z Agencji kontrola, jakaś firma, siedzimy $w$ domu, ja siedzę, patrzę, ktoś mi po polu biega, bez koszulki w szortach, chlopak coś przykuca, coś wchodzi, tam kozy były upięte. Ja mówię do męża: popatrz ktoś nam po polu chodzi. On wsiadt na rower, jedzie i mówi: puść psa. No bo wiadomo, kto to? Niewiadomo! A tam zwierzęta chodza. Ja nie, nie puszczę (śmiech). I on pojechat iokazało się, że to byt wielki pan kontroler, miat przy pasie przypięty, przy szortach identyfikator i on mi kontrole robit.

B. Styszałem, że maja prawo do niezapowiedzianych kontroli? 
R. Dobrze, dobrze, niezapowiedziana $w$ porzadku, ale niech wejda brama (krzyczy). To tak jakbym do kogoś do domu oknem weszła. No jak to tak można? No ludzie? Mieszkam $w$ bloku, siedzę sobie załóżmy w kuchni, a ktoś mi buszuje po dużym pokoju, bo wszedt oknem. (...) Potencjalny złodziej zwierzat. Tam kozy były upięte.

Często poruszanym problem przez rolników w wywiadach, znajdującym również swe echo $\mathrm{w}$ omawianym dokumencie jest problem wymogów sanitaryjnoweterynaryjnych, jakie są stawiane przetwórniom, co $\mathrm{w}$ rezultacie uniemożliwia rozwój drobnego przetwórstwa. Rolnicy, którzy mieli okazje być na Zachodzie twierdzą, iż o sukcesie tamtejszych gospodarstw decydują właśnie przetwórnie umożliwiające wytwarzanie droższych produktów, poprzez kontrole całego procesu produkcyjnego, a nie tylko sprzedaż surowców pierwotnych. Ponadto, przetwarzając rolnicy nie marnują nigdy warzyw czy owoców, których nie są w danym momencie sprzedać. W Polsce zaś takie same wymogi sanitarno-weterynaryjne są stawiane małym przetwórniom, jak i wielkim. W analizowanym tekście z "Eko Arki" pojawiają się również dosyć szczegółowe problemy, które jednak składają się na całościowy obraz niezadowolenia $\mathrm{z}$ dotychczasowej polityki rolnej $\mathrm{i}$ ustawodawstwa. Przykładowo, zakaz uboju zwierząt na terenie gospodarstwa w sytuacji urazu czy złamania, ubojnie często są oddalone ponad $50 \mathrm{~km}$ od gospodarstwa, a zwierzę niepotrzebnie cierpi, a rolnik nie może uratować wartości rzeźnej zwierzęcia.

Problemem ekologicznego rolnictwa również wspomnianym $\mathrm{w}$ uchwale i wywiadach jest brak sieci ekologicznych przetwórni. Wielu rolników w związku z tym korzysta z konwencjonalnych mleczarni i zakładów przetwórczych, przez co ekologiczna wartość ich surowca traci na znaczeniu, gdy zostaje zmieszany z surowcami pochodzącymi z technologicznego rolnictwa. Podobnie brak jest rzeźni ekologicznych oraz przetwórni, jak podsumowuje łódzki rolnik: jakbym zażądał za mojego barana 30\% więcej, bo był ekologiczny, $w$ rzeźni wybuchliby śmiechem. Sprawne, ekologiczne przetwórnie pozwalałyby lepiej zarobić eko-rolnikom na produkcji, gdyż towar nie przetworzony jest znacznie tańszy.

W omawianej deklaracji eko-rolnicy obawiają się zapowiadanych zmian przepisów dotyczących gospodarstw ekologicznych na lata 2007-13 (m.in. niekorzystna zmiana systemu dopłat, zakaz pewnych tradycyjnych form kompostowania) i skarżą się na brak stabilnej polityki rolnej gwarantującej trwatość rodzimych gospodarstw ekologicznych. Uchwała kończy się dramatycznym zapytaniem, nawiązującym do trudniejszej, ich zdaniem, sytuacji eko-rolników 
w stosunku do konwencjonalnych: należy $w$ tym miejscu zadać pytanie czy współczesny rolnik ekologiczny to historyczny kułak, na którego nakłada się obowiązki a ogranicza prawa? Czy nie zostało naruszone konstytucyjne prawo równości wszystkich obywateli?

Ciekawe wątki przynosi wypowiedź właściciela dużego gospodarstwa ekologicznego i przetwórni nabiału z Pomorza:

Gospodarstwa ekologiczne powinny być trochę inaczej traktowane przez, przez Państwo, przez administrację. Ja nie mówię o stworzeniu jakiś, powiedzmy tam sobie, warunków takich wie Pan $w$ sensie prawa, natomiast trochę więcej tolerancji, trochę więcej, troche więcej, że tak powiem, no, życzliwości ludzkiej czego u nas często $w$ urzędach brak. Ja już nie mówię tutaj o mnie, bo ja te wszystkie etapy przeszedtem i wiem, na czym to polega, natomiast wiem gdzie, gdzie tkwi problem kiedy mtode, młody rolnik czy nowe gospodarstwo próbuje coś zrobić. Przeszkody biurokratyczne, obwarowania przepisów prawne sa tak przerażajace, że często ludzie już na etapie startu, pomystu poddaja się, znaczy, albo zmieniaja profil, albo zmieniaja profesję i to jest błąd uważam, że $w$ tym kierunku właśnie powinno, tutaj troszeczkę, przepisy powinny się troszkę, być , no, bardziej liberalne i raczej zachęcać do tworzenia tego typu przedsięwzięć, a już nie mówię, że tylko mleczarni ale przetwórni owoców, przetwórni warzyw, przetwórni mięsa, no wszystkiego co .. i to powinno być na wsi. I to powinni robić właśnie rolnicy, którzy się tym zajmuja. Może nie oni bezpośrednio, może spółdzielnie, może jakieś spótki, prawda, może jakieś zrzeszenia, ale to się musi dziać na wsi nie $w$ mieście bo, bo $w$ momencie kiedy to się, robi się z tego jakiś tam potężny, jeżeli robi się przetwórnie rzędu 5-10-10o tysięcy litrów mleka dziennie to nie jest to żadna przetwórnia tylko jest to jakiś tam moloch, który $w$ zasadzie jest, na który rolnik nie ma żadnego wpływu. I potem mamy to, co mamy, a więc mamy taka żywność, jaką mamy.

W wypowiedzi tej znajdujemy motyw rygorystycznych przepisów unijnych, które powstrzymują rolników od prowadzenia działalności przetwórczej. Przepisy powinny być zdaniem owego rolnika, bardziej liberalne, czyli procedury biurokratyczne związane $\mathrm{z}$ rejestracją działalności czy inwentaryzacją na tyle uproszczone i tolerancyjne, aby nie zniechęcały ludzi do rolnictwa. Syndrom zniechęcenia przepisami pojawiał się w wielu wywiadach, często rolnicy deklarowali, iż musieli zrezygnować z hodowli zwierząt lub rozważają likwidację stada, bo nie potrafili sprostać wymaganiom weterynaryjno - sanitarnym. W przytoczonej wypowiedzi pojawia się inny ważny wątek: potrzeba lokalizacji przetwórstwa na wsi jako klucza do niezależności finansowej rolników. Widzimy tutaj powiązanie rozwoju 
drobnej przetwórczości z kwestią misji rolnictwa ekologicznego, bowiem duże miejskie przetwórnie produkują żywność przemysłową, przeciw której eko-rolnicy buntują się.

Innym zgłaszanym przez rolników problemem jest spowodowana przez unijne wymogi zmiana charakteru ich pracy z fizycznej na umysłowo-fizyczną związaną z obowiązkami księgowo-dokumentacyjnym, procesem certyfikacji. Są to bolączki epoki, gdy nawet zwierzęta muszq latać z paszportami. Często stroną księgową gospodarstwa zajmuje się żona rolnika, ale nie we wszystkich przypadkach. Symptomatyczne jest, że rolnicy uznają pracę na roli za rzetelna czy prawdziwa, podczas gdy księgowanie jawi się im jako zbędne utrudnienie. Egzemplifikacje tej postawy znajdziemy w niniejszej relacji pomorskiego rolnika, który jak wielu woli być po prostu rolnikiem niż rolnikiem-urzędnikiem:

$Z$ uwagi na to, że Unia dzisiaj wymaga od nas masy biurokracji, przez to właśnie ja mam coraz mniej czasu na takq rzetelna, na taka typowa prace a muszę zajmować się właśnie dokumentacja, gromadzeniem tej dokumentacji przed wystaniem informacji, robieniem zestawień i tak dalej. To mnie boli, bo ja lubię pracować, natomiast nie lubię, nie jestem urzędnikiem a te wtaśnie struktury unijne wymusity na nas, że tak powiem, no te, te obowiazki biurokratyczne, więc tworzenie tej, tych papierków, tych wszystkich tam prawda informacji, rozliczeń, wniosków, całej reszty. Mi to osobiście ani nie pasuje ani nie jestem tego zwolennikiem, byłem, to mnie raczej męczy póki co. Może, może czas pokaże, może z czasem się do tego przyzwyczaję, ale na razie jest to dla mnie, że tak powiem, to zto konieczne.

\section{Pomyshy na rozwój rolnictuva ekologicznego.}

Większość pomysłów na rozwój rolnictwa ekologicznego, jakie poznałem $\mathrm{w}$ toku badań, dotyczyło zaradzenia bieżącym bolączkom, likwidacji barier instytucjonalnych w postaci przepisów uznawanych za nieżyciowe, rozwoju punktów informacji o rolnictwie ekologicznym w Ośrodkach Doradztwa Rolniczego, itp. Ekorolnicy zgłaszali potrzebę doradców polowych, bez posadek $w$ mieście, tylko siedzqcych tu na miejscu i mówiących człowiekowi, jak się ma zachować, bo tego rolnictwa ekologicznego się trzeba uczyć i musza na to pójść pieniądze. Część idei zmierzało do tworzenia silnych grup producenckich. Otwarcie się sklepów wielkopowierzchniowych dało impuls do integracji eko-rolników, powstały organizacje ogólnopolskie i lokalne nastawione na przedstawianie wspólnej oferty 
handlowej, takie jak charakteryzowane w Rozdziale IV Eko-Centrum Zelów czy świętokrzyska Eko Nida. Rolnicy ekologiczni nabierają świadomości, że hurtowy odbiorca może negocjować z grupą kilkunastu eko-rolników, a nie z pojedynczymi gospodarzami. Problem w tym, że ciągle skupisk eko-rolników jest mało, a na dodatek często ich produkcja jest zróżnicowana, co stanowi atut dla pojedynczych konsumentów, ale nie dla hipermarketu, który wolałby by węższą specjalizację grupy - potrzebuje przykładowo dużo jabłek, a nie trochę jabłek i gruszkę, trochę mleka krowiego i trochę koziego.

Prowadzenie własnego przydomowego przetwórstwa jest postrzegane jako ważny czynnik niezależności rolnika i optymistycznym wskaźnikiem jest postępujący wzrost liczby przetwórni ekologicznych w Polsce z 90 w roku 2005 do 207 w roku 2007 (IJHAR-S dane na 31.12.2007). Przetworzone produkty przykładowo w postaci serów, masła, soków, pasztetów warzywnych, chleba, ciast, dżemów można bowiem sprzedać znacznie drożej niż produkty w nieprzetworzonej formie. Ponadto, jeśli rolnik przetwarza, tworząc na przykład koncentrat pomidorowy nie zmarnują mu się nigdy pomidory, na które nie znalazł w sezonie zbytu, co znacznie poprawia jego sytuację ekonomiczną. Najbardziej znani polscy eko-rolnicy ugruntowali swoją pozycje na rynku dzięki przetwórstwo, jak na przykład wytwórca makaronu Aleksandra i Mieczysław Babalscy. Znany ekologiczny producent nabiału Bogusław Klimczak (1995) dzielił się z innymi rolnikami optymizmem i przekonaniem płynącym z własnego doświadczenia, że przetwórnie da się stworzyć od zera, bez znacznych nakładów finansowych:

Jestem przekonany, że tzw. małe przetwórstwo można uruchomić $w$ każdym gospodarstwie ekologicznym $i$ wcale nie trzeba od razu $<<r z u c a c ́$ się>> na wielkie inwestycje. Wystarczy najpierw rozważyć, jaki surowiec się produkuje, i zastanowić się, jak to przetworzyć, by lepiej sprzedać. Najlepszym surowcem jest zazwyczaj ten, którego jest nadmiar na rynku, i który przez to trudno korzystnie sprzedać. Do ruszenia $z$ przetwórstwem wystarcza proste narzędzia i przedmioty, które -jak się dobrze rozejrzymy $w$ gospodarstwie - na pewno się znajda, a nawet same będa "w ręce wchodzić". Najważniejsze to zaczać coś robić i zaskoczyć klienta nowościa rynkowa. Nierzadko może to być stara babcina recepta na oryginalny wybór, np. gomótki z sera (s. 111)

Zdaniem tego rolnika, istota sukcesu leży w percepcji rzeczywistości, czynnikach subiektywnych, takich jak pozytywne nastawienie, odwaga, odpowiedzialność rolnika: 
Nie należy się koncentrować na przeciwnościach i przeszkodach, bo to strata czasu i energii. Najlepiej wypisać na kartce w punktach argumenty za rozpoczęciem przetwórstwa $i$ osobno argumenty przeciw, i porównać. Już podczas wypisywania może się okazać, że te argumenty przeciw, które nas przyttaczały, nie sq takie straszne, $i$ że problemy sq do rozwiazania. Tak naprawdę, to żadnych obiektywnych przeszkód nie ma, sq tylko nasze ograniczenia, wykręty i nieelastyczność; warto to sobie uzmystowić i przyznać się do tego, bo wtedy tatwiej się od tego uwolnić. Niektórym pomaga modlitwa $w$ tej intencji. Odkąd wybratem odpowiedzialność za siebie i swoje decyzje, wszystko idzie mi łatwiej, bo nie tracę czasu na bezowocne użalania. (Klimczak ibidem: 111-112)

Dalsze pomysły obejmują rozwój ekologicznej agroturystyki, choć niektórzy rolnicy cenią sobie prywatność i odżegnują się od tej formy zarobkowania. Niemniej, prężenie działa polski oddział Stowarzyszenia ECEAT (The European Centre for Ecological Agriculture and Tourism), grupującego ponad 200 polskich gospodarstw ekologicznych. Stowarzyszenie pośredniczy w kontaktach gospodarzy z polskimi i zagranicznymi turystami. $\mathrm{W}$ roku 2001 polski oddział organizacji otrzymał nagrodę British Airways jako najlepszy przykład Turystyki Przyszłości (Magazyn Obywatel 4/2001: 9).

Pewnym pomysłem jest poszerzenie działalności gospodarstwa o działalność edukacyjną, stworzenie eko-gospodarstwa edukacyjną z oferta dla miejskich dzieci i młodzieży. Doświadczeni eko-rolnicy demonstrują swe gospodarstwa i dzielą się wiedza i doświadczeniem z adeptami tej sztuki. Państwo Wyrwiccy, mazowieccy ekorolnicy z Osiecka, wprowadzili inicjatywę Otwartych Wrót, wyznaczając dni, w które goście z miasta mogli obejrzeć gospodarstwo i zapoznać się z tajnikami produkcji ekologicznej. Zaczęli prowadzić zajęcia dla grup dzieci. Edukacja ekologiczna dla szkół jest elementem pracy misyjnej, ale także możliwym źródłem dochodu dla ekorolników, którzy jednakże często skarżą się na brak czasu, aby się tym zajmować. Jadwiga Łopata (2002) z ulokowanego na małopolskiej wsi Międzynarodowej Koalicji dla Ochrony Polskiej Wsi zaproponowała 3-4-godzinny program edukacji ekologicznej dla grup szkolnych poprzez pobyt na gospodarstwie:

Taka żywa lekcja - skąd się bierze prawdziwy chleb, jak się go piecze, jak smakuje, jak pachnie. Jak wygladaja różne rośliny $i$ zwierzęta, jak się z nimi obchodzić. Żadna lekcja $w$ mieście, $w$ murach szkoly, nie da takiej wiedzy i wrażliwości na naturalne, tradycyjne elementy życia (s. 9). 
Ważnym czynnikiem rozwoju rolnictwa ekologicznego jest rozwój infrastruktury okołoprodukcyjnej, instytucji państwowych wspomagających jego rozwój, punktów informacji w każdej gminie, szkół nauczających tego rodzaju rolnictwa. W Danii działa już od 1992 Akademia Rolnictwa Ekologicznego, organic farming - to cieszący się powodzeniem interdyscyplinarny kierunek wielu zachodnich uniwersytetów, ciesząca się silnym wsparciem rządu, w Polsce nie ma wyższej uczelni zajmującej się nauczaniem eko-rolnictwa, lecz po mału eko-rolnictwo toruje sobie drogę do średnich i wyższych szkół rolniczych. Jeżeli chodzi o Ośrodki Doradztwa Rolniczego (ODR-y) to niektóre czynnie propagują rolnictwo ekologiczne, organizują kursy, ułatwiają rolnikom kontakt z innymi rolnikami ekologicznymi, podczas gdy inne nie potrafią udzielać podstawowych informacji. Z narracji rolników wynika, iż ODR-y są placówkami, które cieszą się dużą rozpoznawalnością oraz społeczną legitymizacją i z pewnością można w większym zakresie przystosowywać je do doradztwa w zakresie eko-rolnictwa. Jak zauważa eko-rolnik z łódzkiego, wieś jest niedoinformowana co do szkoleń i przepisów, a informacje często trzeba z państwowych informacji "wyrwać", na dodatek odczuwa braki w zakresie kompetentnych materiałów szkoleniowych:

Ja tu ubolewam, $w$ ogóle informacja na wsi jest tragiczna, sa ludzie niepoinformowani, jakąś plotkę ustysza, by się dowiedzieć czegokolwiek wiarygodnego to sa straszne problemy. W tej chwili, jak się już troszkę wdrożyliśmy, jeździmy na targi, szkolenia, organizowane przez WODRy, ale to wszystko można powiedzieć, się wyrywa te informacje. Dużym bankiem danych, które sq aktualizowane, te zmiany prawne sq $w$ tej chwili jednostki certyfikujące, my jesteśmy $w$ Ekogwarancji $i$ bardzo sobie chwalimy, bo oni naprawdę doradza i można powiedzieć, tak się opiekuja, nie? Wszystkie nowe informacje sa na bieżaco przesyłane do ekorolników, to jedynie $w$ ten sposób. Ale ciągle bazujemy na przekładzie podręcznika rolnictwa ekologicznego, przedruku $z$ niemieckiego, niemieckich realiów i to jedyny podręcznik praktyczny. $Z$ roślinami, płodozmianem to jeszcze pót biedy, ale jak wchodza w grę zwierzęta, to im się kartki nie napisze, nie jest tatwo.

Pewnym rozwiązaniem wspierającym rozwój rynku rolnictwa ekologicznego jest rozwój ruchu spółdzielczego, ekologiczne spółdzielnie rolne odpowiadają za znaczną część produkcji tak w krajach rozwiniętych, jak i rozwijających się, podczas gdy w Polsce ruch spółdzielczy wykazuje się pewną słabością. Socjolog wsi Paweł 
Starosta (1999) upatrywał w rozwoju spółdzielni jeden ze sposobów koncentracji kapitału i nadążenia za wyzwaniami globalizacji (s. 384). Zdaniem tego autora, spółdzielnie funkcjonujące zwłaszcza $\mathrm{w}$ branży produkcji rolnej i przetwórstwa, mogłaby znacząco ułatwić dystrybucję płodów rolnych i zwiększyć dochody rolników (Starosta ibidem: 384-385).

Eko-rolnicy sami zastanawiają się nad pomysłami na rozwój własnej działalności produkcyjnej. Popularnością cieszą się idee produkcji na rynek zachodni, choć największe szanse przedstawiają produkty niszowe, nieprodukowane na Zachodzie, takie jak np. kwas chlebowy. Oto fragment opowieści eko-rolnika i właściciela piekarni:

Jeżeli chodzi o ekologię to próbowatem wypiekać chleb ekologiczny z mieszanek ekologicznych, coś takiego się pojawiło $w$ Częstochowie - firma, która proponuje gotowe mieszanki z certyfikatem, ja tylko dodaje wodę, fermentacja i gotowy produkt. Ale chleb ten jest za drogi, nie ma na to klientów. Natomiast nawiązatem kontakt z producentem kwasu chlebowego, to jest taki napój krajów wschodnich, on też tam kontakty ztapat $i$ warunkiem dalszego zbytu tego kwasu jest, jeżeli będzie posiadat certyfikat, a na Zachodzie jest wielkie zainteresowanie: głównie Niemcy, Austria, trochę Wtochy, nawet Izrael jest zainteresowany, troche już wysyta, ale ja musze mieć certyfikat na wszystkie produkty, chleb, stód moja piekarnia musi być pod kontrola. Musze zgłosić, że w takich i takich godzinach $w$ tej piekarni nie produkuje się niczego innego poza tym chlebem razowym na kwas. Trzeba wreszcie podpisać umowe z Niemcami, Demeter, szczęśliwie polska firma, która będzie tu certyfikować daje szanse wystania tego na Zachód.

Niemniej warto podkreślić, że nastawienie się na produkcję na eksport nie jest do końca ekologiczne choćby ze względu na ekologiczne koszta transportu. Zbigniew Przybylak (2009b) zwraca uwagę, iż sprzedaż bezpośrednia jest, najbardziej pożądana $w$ ekologicznym gospodarowaniu, jest ukierunkowaniem na rzecz społeczności lokalnych, narodowych. Eksport jest elementem dodatkowym. Jednocześnie autor ten podkreśla spoleczny wymiar sprzedaży bezpośredniej i fakt, że zachęca ona do podnoszenia jakości gdyż nie sprzedaje się "w nieznane" (s. 1). Eko-rolnicy często podkreślają fakt, iż dzięki sprzedaży bezpośredniej dodatkowo zyskują tworząc relacje przyjaźni z klientami, którzy lubią czasami odwiedzać ich gospodarstwa i wspomagają ich, płacąc z wyprzedzeniem za dostawy.

Pewną ideą na rozwój rolnictwa ekologicznego jest inspirowanie polskich rolników zagranicznymi praktykami. Jak wykazałem w podrozdziale poświęconym 
procesowi stawania się rolnikiem ekologicznym, pobyt na eko-gospodarstwach w krajach, gdzie produkcja ekologiczna jest bardziej zaawansowana był ważnym etapem w trajektoriach zawodowych polskich eko-rolników, którzy odnieśli sukces gospodarczy. Obecnie niektóre urzędy marszałkowskie organizują wyjazdy ekorolników na największe światowe targi żywności ekologicznej BioFach do Norymbergii. Obecność na targach może rozbić pierwotne naiwne złudzenia, co do latwości eksportu na Zachód, lecz może mieć efekt inspirujący, wskazując rolnikom możliwe drogi rozwoju. Jednakże wizyta na Zachodzie prowadzi do zauważenia ogromnego dystansu, jaki dzieli polskie eko-rolnictwo od zachodniego. Oto relacja łódzkiego eko-rolnika $\mathrm{z}$ konfrontacji $\mathrm{z}$ rzeczywistością światowego rolnictwa ekologicznego na owych targach:

Pojechatem z nadzieją zobaczenia jakiejś tam produkcji, a wrócilem, kurde, zdziwiony bardzo rozmiarem tej produkcji, na świecie wszystko się już robi ekologicznie: Można powiedzieć, nie ma gałęzi, gdzie jest luka, poczquszy od tam żywności, tkaniny, kosmetyki, chyba nie ma niszy, luki jakiejś tam, gdzie można by się przebić. Bardzo duża produkcja jest win, aż się dziwie, że w taki sposób produkuje się tyle win, tysiące gatunków. 


\section{Wnioski końcowe}

Rolnictwo ekologiczne staje się coraz ważniejszym obszarem działalności człowieka. Wpisuje się idealnie w zmiany, jakie zachodzą na obszarze filozofii rolnictwa w rozwiniętym świecie. Jak zauważa specjalista ds. ekonomii rolnictwa prof. Jerzy Wilkin, rolnictwo w mniejszym stopniu niż dawniej stawia funkcje produkcyjną za główny cel, obecne w UE dopłaty do rolnictwa wynikają z chęci zachowania naturalnego, wiejskiego krajobrazu ze względu na jego wartość ekologiczną i ekonomiczną (np. turystyka). Prof. Wilkin podzielił się następującym spostrzeżeniem: niektórzy ekonomiści wyobrażaja sobie Europę bez rolnictwa, mówią, że rolnictwo stanowi mniej niż kilka procent PKB i gospodarka mogłaby się bez niego obejść. Pomijając koszty ekonomiczne, wieś nie może istnieć bez rolnictwa, a Europa bez wsi straciłaby swoją duszę (wypowiedź na seminarium stypendystów Fundacji im. H.Boella, Tykocin 2006).

Rolnictwo ekologiczne stanowi alternatywę dla rolnictwa konwencjonalnego. Można stwierdzić, iż tworzą one dwa skłócone społeczne światy, mające jednak cechy wspólne (produkcja żywności). Podstawowym działaniem społecznego świata rolnictwa ekologicznego jest produkcja żywności ekologicznej. Polskie rolnictwo ekologiczne rozwija się dynamicznie, w tej chwili jest blisko 10 tys. gospodarstw ekologicznych w Polsce. Wstąpienie naszego kraju do UE w 2004 roku spowodowało blisko 3-krotny wzrost, przypadający na okres dwóch lat i w związku z tym mający dość chaotyczny charakter. Istotne są dysproporcje regionalne w rozwoju ekorolnictwa, najwięcej eko-gospodarstw przypada na tereny dawnej Galicji, a najmniej na obszar Śląska, a różnica pomiędzy województwami małopolskim i opolskim jest ponad 20-krotna.

Same dane świadczące o wzroście powierzchni gospodarstw mogą prowadzić do zbyt pochopnego optymizmu, który hamuje analiza produktywności tych gospodarstw i analiza rozwoju rynku produktów ekologicznych w Polsce. Peter Stratenwerth (2006), pochodzący ze Szwajcarii, ale osiadły w Polsce eko-rolnik, szacuje w swej publikacji "Wsi spokojna, wsi wesoła"

iż najbardziej poszukiwane przez klientów warzywa, uprawia się na zaledwie niespetna 1\% obszaru upraw ekologicznych. Owoce, $w$ tym owoce miękkie, rosna tylko na 4,2\% areatu (szacunkowe dane uzyskatem od inspektorów jednostek certyfikacyjnych). Tylko okoto 20\% kontrolowanych gospodarstw ekologicznych prowadzi 
produkcję towarowa. Znaczna część plonów rolnictwa ekologicznego trafia nadal do przetwórni i na rynek produktów konwencjonalnych (s. 18).

W ocenie Stratenwertha (ibidem), rolnictwo ekologiczne $w$ Polsce wciąż jest jeszcze $w$ roli kopciuszka, mimo że zbyt na polskie produkty ekologiczne $w$ Polsce i zagranica wzrasta dynamicznie. Wielu eko-rolników, z którymi przeprowadziłem wywiady wspominało, że ich wysiłek produkcji ekologicznego mleka czy jabłek idzie na marne, gdyż brak jest przetwórców i konsumentów zainteresowanych ich wyrobem. Niektórzy, zazwyczaj zrzeszeni lub mający duży wolumen produkcji, potrafią sprzedać całą produkcję mleka zagranicę, jak eksportujący do Niemiec biodynamicy z wielkiego gospodarstwa w Juchowie (Stopa 2009), a pozostali sprzedają swe mleko do punktu skupu po bardzo niskiej cenie około 1 zł za litr. Ich mleko traci $\mathrm{w}$ ten sposób swój unikalny charakter wymieszane $\mathrm{z}$ mlekiem konwencjonalnym - stają w roli niedocenianego kopciuszka, który produkuje towar lepszy jakościowo. Uniezależnienie dotacji od produkcji towarowej - wprowadzania produktów ekologicznych na rynek, sprawiło, iż znaczna część subwencji trafia do eko-rolników dotacyjnych i kontemplacyjnych i nie skutkuje rozwojem produkcji ekologicznej.

Nie da się ukryć, że pomimo osiągnięć w zakresie wzrostu areału upraw i liczby producentów i przetwórców, Polska ciągle pozostaje krajem zacofanym w stosunku do UE pod względem rozwoju rolnictwa ekologicznego, gdyż eko-gospodarstwa stanowią 0,5\% ogólnej liczby gospodarstw, podczas gdy według średniej dla UE stanowią 9\%. Argumentem przywoływanym dla poprawy samopoczucia Polaków jest rzekomy niższy stopień chemizacji ogólnej liczby gospodarstw, wynikający z zacofania technologicznego w okresie PRLu, co daje zwolennikom rolnictwa konwencjonalnego podstawy do mówienia o ogólnej ekologiczności polskiego rolnictwa. Z drugiej strony, jak zauważył czołowy propagator eko-rolnictwa prof. Mieczysław Górny, owa ekologiczna przewaga Polski nie wynikała wcale z wyższej świadomości ekologicznej polskich rolników, ani nie była rezultatem jakiejkolwiek państwowej strategii zarządzania stosowaniem środków chemicznych, lecz następstwem gorszej sytuacji ekonomicznej polskich rolników. W rzeczywistości świat społeczny rolnictwa konwencjonalnego skupiający potężny międzynarodowy i krajowy agrobiznes dysponuje nieskrępowaną wolnością w propagowaniu sztucznych nawozów i środków ochrony roślin. 
W tym miejscu warto zasygnalizować, iż usłyszałem od badaczki rolnictwa ekologicznego z Finlandii, iż w jej kraju podobnie się uważa, że produkty fińskiego rolnictwa konwencjonalnego jako takie są zdrowsze i mniej chemizowane niż produkty importowane. Być może to przekonanie o ekologiczności krajowego rolnictwa jest powszechne w większej ilości krajów Europy i ma więcej do czynienia z dumą narodową niż rzeczywistymi wskaźnikami stosowania sztucznych nawozów i pestycydów.

Obecnie pilnym problemem $\mathrm{w}$ konfrontacji dwu światów społecznych jest kwestia genetycznie modyfikowanej żywności, jednogłośnie odrzucanej przez rolników ekologicznych (deklaracja Międzynarodowej Federacji Rolnictwa Ekologicznego IFOAM w tej sprawie była wydana już w 1988 roku). Zdaniem wielu rolników ekologicznych, zgoda na genetycznie modyfikowane uprawy groziłaby kresem ich świata, gdyż trudno jest postawić tamę rozprzestrzenianiu się genetycznie modyfikowanych nasion. Ważna organizacja zajmującą się promocją i rozwojem rolnictwa ekologicznego - Międzynarodowa Koalicja na rzecz Ochrony Polskiej Wsi w całości poświęciła się obecnie kampanii zapobiegania wprowadzenia do Polski genetycznie modyfikowanej żywności.

Postrzegam dużą różnorodność polskich rolników ekologicznych. Opierając się przede wszystkim na własnych kategoriach badanej zbiorowości, można wyodrębnić typ niemotywowanego ideowego $\mathrm{i}$ nieobeznanego $\mathrm{z}$ zasadami ekologii rolnika dotacyjnego, dla którego motywacją w ekologicznej konwersji była wysokość unijnych dotacji, jak i eko-rolników z misją, godzących zawód i powołanie, stopniowo oswajających się $\mathrm{z}$ wymaganiami rynku, czerpiących jednak siłę $\mathrm{z}$ przekonania o moralnej wartości swej pracy. Spośród eko-rolników z misją, wyróżniłem dwa podstawowe podtypy: skupionych wokół Stowarzyszenia "Ekoland" pionierów i adeptów. Pionierzy przecierali szlaki w epoce początków polskiego eko-rolnictwa, gdy nie istniały sformalizowane reguły, a rynek zbytu żywności ekologicznej sami musieli stworzyć, przemierzając niekiedy całą Polskę, aby dotrzeć na jarmark pod warszawskim domem kultury. Adepci odczuwają wspólnotę wartości z pionierami, uczą się na ich doświadczeniu, jednakże dopiero zaczynają swoją przygodę $\mathrm{z}$ rolnictwem ekologicznym, są to rolnicy $w$ trakcie przestawiania lub z niedawno przyznanymi certyfikatami. Jest również rzesza gospodarstw, często nieprodukujących na potrzeby rynku, prowadzonych np. przez organizacje religijne, uznające samoistną, terapeutyczną lub duchową wartość fizycznej pracy na roli, 
interakcji z Przyrodą, czy doświadczenia mistycznej jedności z Przyrodą w rolnictwie. Ten typ osób, dla których rolnictwo nie jest podstawowym komponentem tożsamości określiłem mianem eko-rolników kontemplacyjnych.

Na przykładzie lokalnej organizacji Eko-Centrum Zelów dostrzegłem, iż młodzi stażem rolnicy, którzy zdecydowali się na konwersję motywowani względami ekonomicznymi, dostrzegają znaczenie misji i niezwykły charakter swego zawodu. Lider tej organizacji widzi zespolenie własnego interesu ekonomicznego z ideologicznym, im więcej rolników namówi na ekologię, tym więcej sam w dłuższej perspektywie zarobi, gdyż tylko zrzeszenie gospodarstw może zaproponować atrakcyjną ofertę zagranicznym kontrahentom lub sklepom wielkopowierzchniowym. Chodząc po wsiach i wykonując pracę misyjna, myślał zarówno o własnym interesie ekonomicznym, jak i zabieganiu o zdrowie społeczeństwa, poprzez dostarczanie zdrowej żywności. Główna idea rolnictwa ekologicznego zakłada bowiem, iż zdrowa gleba prowadzi do zdrowych roślin, które sprzyjają zdrowiu zwierząt i ludzi. Z moich badań wynika, iż choć istnieją eko-rolnicy dotacyjni, to sukces zawodowy odniosą raczej ci eko-rolnicy, którzy potrafią dostrzec szerzej pojęty własny interes.

W społecznym świecie rolnictwa ekologicznego przywiązuje się dużą wagę do przestrzegania katalogu podstawowych wartości, z których centralną wartość stanowi miłość do Przyrody. Z ową wartością wiążą się inne: wiara i nowe myślenie, dobro, uczciwość, ratowanie bioróżnorodności, zdrowe i szczęśliwe zwierzęta, samowystarczalność i wzajemna współpraca.

Miłosny stosunek do Przyrody to podstawa ekologicznego gospodarowanie, jego dowodem jest nie trucie Przyrody sztucznymi środkami i dbałość o nią. Praktykowanie owej miłości powoduje, iż Przyroda staje się sojuszniczką rolnika, współpracuje z nim. W milosnym stosunku do Przyrody dostrzec można elementy postawy kontemplacyjnej: czuje się przyjemność, że się widzi tą Przyrodę $w$ stanie nienaruszonym (miłość do Przyrody jako cel), jak i element celowościowo -racjonalny - opłaca ze względu na owoce, jakie przynosi - efektywniejsze funkcjonowanie gospodarstwa (miłość do Przyrody jako środek). Postawa miłosna wobec Przyrody wymaga nowego, holistycznego i systemowego myślenia, świadomości współzależności występujących w Przyrodzie, mających, jak wskazuje biodynamika wymiar kosmiczny i wiary, iżjest to możliwe.

Rolnicy ekologiczni mają przekonanie, iż gospodarując w zgodzie z Przyrodą i siłą wyższą służą dobru. Znamienna w tym kontekście jest dewiza "nestora rolnictwa 
ekologicznego" profesora Górnego (2005b), wedle którego jak w życiu człowiek bardzo pragnie robić coś dobrego, to sa gdzieś $w$ Niebie siły, które będa nad nim czuwaty (s. 33). Deklaracja ta wskazuje na nierozerwalną relację dobra i wiary. Rolnicy ekologiczni uważają, iż służą Dobru, gdyż w przyjazny czy jak to ujmują niektórzy pełen miłości sposób traktują glebę, rośliny i zwierzęta, buntując się wobec chemii określanej niekiedy mianem siłą śmierci i obwinianą za degradację środowiska naturalnego i liczne choroby, na jakie cierpi człowiek. Zdaniem profesora Górnego (2002), istotą dobra jest właściwy stosunek do świata i do ludzi. Wtaściwy znaczy taki, który jest korzystny nie tylko dla człowieka, ale i dla innych istot.

W kolejnej wartości - uczciwości rolników ekologicznych pojawia się silny egalitaryzm, rolnictwo ekologiczne to rodzaj protestu wobec traktowania konsumentów jako ciemnej masy. W wypowiedzi pewnej rolniczki pojawia się stanowczy imperatyw moralny uczciwości w odniesieniu do rolniczej praktyki, nawet, jeśli wiązałaby się ona z mniejszymi zarobkami: Taka uczciuvość, największa uczciwość powinna być $w$ samym rolniku, (...) bo ekolog to jest taki czlowiek, który może biedniej żyć, ale on tam nie popryska, prawda? (podkr. PB). Kolejne kluczowe wartości rolnictwa ekologicznego to ratowanie bioróżnorodności (np. zachowanie starych odmian drzew, roślin i zwierząt) i zgodność z lokalnymi tradycjami upraw, dążenie do utrzymania niewymuszonego krajobrazu, czyli minimalizacji ingerencji człowieka. Zdrowe i szczęśliwe zwierzęta element dobrostanu całego gospodarstwa i realizacji dobra. Rolnicy ekologiczni niekiedy posługują się perspektywą antropomorficzną, twierdząc, iż zwierzęta doceniają lepsze traktowanie i pożywienie, że czują się szczęśliwsze. Kolejną wartością, którą uwzględniłem jest samowystarczalność, znajdująca wyraz w dążeniu rolników ekologicznych do niezależności od koncernów chemicznych i państwa, do formy niezależności dającej wyraz ekologicznej koncepcji gospodarstwa jako zamkniętego obiegu. Ostatnią wartością jest wzajemna współpraca, wskazująca, iż eko-rolnicy chętnie sobie pomagają na przykład w zakresie sprzedaży produktów i choć również rywalizują, konkurencja ta ma raczej przyjazny wymiar. Analiza katalogu wartości rolnictwa ekologicznego pozwala zaliczyć ruch rolników ekologicznych to tzw. nowych ruchów społecznych (Klandermans, Mellucci, Touraine, Offe) zorientowanych na wartości postmaterialistycznie, przedkładające wartości ekologiczne, jakość życia nad zysk materialny. 
Podjąłem się próby stworzenia możliwie jak najbardziej trafnego wytłumaczenia procesu stawania się rolnikiem ekologicznym na podstawie poznanych doświadczeń rolników, zastrzegając dynamiczny wymiar tego procesu i dostarczając przykłady wyjątków stanowiących przykłady graniczne. Wyróżniłem trzy zasadnicze etapy: zarażanie się, nauka i dojrzałość, składających się z pomniejszych faz. Proces stawania się rolnikiem ekologicznym zaczynał się w momencie, kiedy rolnik lub rolniczka prowadzili gospodarstwo metodami konwencjonalnymi. W pewnym momencie osiągali punkt zwrotny, który określiłem wyłaniającą się z empirii kategorią zmęczenia chemią, stanu, na który składała się obserwacja nieskuteczności chemicznych środków ochrony roślin i nawozów, jak i pewne zakłopotanie natury moralnej (czy ja nie krzywdze ziemi?). Wówczas pierwszym impulsem okazywała się informacja o kursie rolnictwa ekologicznego przekazana przez znajomego lub przeczytana w prasie rolniczej, Ośrodku Doradztwa Rolniczego. Rolnik decyduje się pójść za owym przypadkiem, kalkulując, iż nie szkodzi dowiedzieć się więcej. Aby posunął się dalej na drodze prowadzącej do stania się eko-rolnikiem musi dojść do zainspirowania, silnego doświadczenia, dostarczenia wyjaśnień i kategorii pasujących do sytuacji, w jakiej się znajdował. Zazwyczaj stadium osobistej przygody było związane $\mathrm{z}$ poznaniem charyzmatycznego lidera ruchu eko-rolników, jakimi byli to Julian Osetek, prof. Mieczysław Górny czy jest długoletni prezes "Ekolandu" - Mieczysław Babalski. Nowopoznani liderzy i ekorolnicy stają się nowymi znaczącymi innymi, osobami, z których opiniami nasz bohater zaczyna się liczyć przy budowie własnej tożsamości. Wkrótce pod wpływem zasięgnięcia informacji, przy zgodzie rodziny lub pomimo jej braku, pojawia się decyzja o konwersji, rozpoczęciu procesu przestawiania gospodarstwa na metody ekologiczne, będąca ważnym progiem, markującym przejście do drugiego etapu.

W drugim etapie rolnik musi nauczyć się zupełnie innej metody i filozofii prowadzenia gospodarstwa, pomocne i inspirujące okazują się porady ze strony bardziej doświadczonych rolników. Niektórym eko-rolnikom udało się pojechać zagranicę, celem poznania tamtejszych gospodarstw ekologicznych, wyjazdy takie obfitowały $\mathrm{w}$ inspiracje, część rolników zostało zarażonych pomysłem otwarcia przetwórni. Rolnik ucząc się eksperymentuje z różnymi technikami rolnictwa ekologicznego (np. kalendarz księżycowy) i w oparciu o empiryczne testowanie reakcji Przyrody przyjmuje, bądź porzuca określone techniki. W etapie nauki i stawiania pierwszych kroków zorientowanych na nową tożsamość, pojawiają się dwie 
zasadnicze bariery: jedna natury ekonomicznej, druga natury społecznej. Pierwsza to początkowy spadek plonów, który jest tłumaczony koniecznością regeneracji gleby i związane z nim znaczące obniżenie dochodów. Druga bariera to drwiny ze strony pierwotnej grupy odniesienia i pierwotnych znaczących innych, sąsiadów i niekiedy również własnej rodziny. Aby podołać tej próbie rolnik musi dobrze czuć się w nowej roli i cieszyć się wsparciem swej nowej grupy odniesienia. Często miały miejsce równoczesne konwersje 2-4 gospodarstw z okolicy prowadzonych przez rolników związanych więziami przyjaźni, im było łatwiej poradzić sobie z ową trudnością.

Jeśli rolnik przejdzie owe dwie ciężkie próby przechodzi do trzeciego etapu, z którym związana jest profesjonalizacja i oswojenie rynku, czyli znalezienie własnej formuły gospodarstwa, postawienie na wszechstronność lub pewną specjalizację, wypracowanie modelu sprzedaży własnych wytworów (sklepy ekologiczne, sprzedaż bezpośrednia, integracja $\mathrm{z}$ innymi rolnikami motywowana opcją na zamówienia hurtowe). Jeżeli okaże się, że produkcja ekologiczna przynosi rolnikowi plony i dochody powtórnie zdobywa uznanie pierwotnej grupy odniesienia, sąsiedzi przekonują się, że można jednak uprawiać bez pryskania i żyć na przyzwoitym poziomie, co może skłonić ich do pójścia w ślady człowieka, z którego dawniej szydzili. Ukoronowaniem procesu profesjonalizacji i wykształcania własnej formuły gospodarstwa jest tzw. znalezienie punktu optimum, znanego w ekologii jako punkt omega. Gospodarstwo i przedsiębiorstwo ekologiczne nie powinny bowiem rozwijać się w nieskończoność, lecz niczym żywe organizmy osiągnąć stadium dojrzałości, w którym posiadany rozmiar gospodarstwa i produkcji zapewnia wystarczająco środków do życia i satysfakcje. $\mathrm{W}$ tej sytuacji rolnik może więcej czasu poświęcić propagowaniu ekologii.

Jeżeli chodzi o legitymizację przynależności do społecznego świata i wyznaczanie jego granic to Stowarzyszenie Producentów Żywności Metodami Ekologicznymi "Ekoland", powołane przez samych rolników i propagatorów ekorolnictwa ze świata nauki i doradztwa rolniczego zajmowało się przez większość dekady lat 90 atestowaniem gospodarstw, decydowaniem, kto jest rolnikiem ekologicznym, a kto nie. Obecnie czyni to siedem wyspecjalizowanych jednostek, mających charakter komercyjnych firm. Niemniej, choć seniorzy czasem tęsknią za czasami dawnego Ekolandu, kiedy mniej myślano o pieniądzach, a więcej o idei, to powszechnie podzielany jest pogląd, iż kryteria przynależności do społecznego świata 
rolnictwa ekologicznego wyznaczane przez firmy certyfikujące są słuszne. Pewien ekorolnik w trzecim roku przestawiania powiedział mi: ja jeszcze nie jestem rolnikiem ekologicznym. Będę nim za pót roku jak dostanę certyfikat. To nie może być tak, że się samozwańczo określamy. Trzeba się opierać o certyfikaty, nie mylić klientów.

Oprócz podstawowego sporu świata społecznego rolnictwa ekologicznego ze światem społecznym rolnictwa konwencjonalnego istnieją inne areny $\mathrm{w}$ ramach pierwszego ze światów społecznych, dzielące go na subświaty. Taką areną jest stosunek do biodynamiki, stworzonej przez Rudolfa Steinera filozofii gospodarowania ekologicznego, podkreślającej znaczenie kosmicznej energii i mającej określoną wizje metafizyczną opartą o antropozofie. Część eko-rolników akceptuje biodynamikę jako wyższe arkana produkcji ekologicznej, wymagające daleko posuniętej integracji człowieka z Przyrodą. Część zaś odrzuca ją jako herezję, odwołując się do wiary katolickiej i nie mogąc znaleźć w katolickim uniwersum symbolicznym miejsca dla trzeciej neutralnej sity Przyrody.

Analizowałem również dwa obiekty graniczne społecznego świata rolnictwa ekologicznego. Pierwszym z nich jest fenomen rolników pół-ekologicznych, praktyki niektórych jednostek certyfikujących pozwalających, aby jeden gospodarz posiadał dwa gospodarstwa i tylko jedno z nich przestawiał na metody ekologiczne. Praktyki takie, choć mało powszechne, spotykają się z powszechnym odrzuceniem, gdyż jak wskazują eko-rolnicy, ekologiem trzeba być calym sobq̨. Istota rolnictwa ekologicznego mieści się bowiem $\mathrm{w}$ sposobie myślenia, $w$ głowie gospodarza. Wartością rolnictwa ekologicznego jest uczciwość związana z faktem, iż produkuje się tylko żywność ekologiczną, tą samą żywność wytwarza się na własne potrzeby i potrzeby klientów. Praktyka polegająca na produkcji jednego typu żywności dla mas, a drugiego typu na własne potrzeby spotyka się z moralnym potępieniem rolników ekologicznych.

Ważnym procesem jest profesjonalizacja i komercjalizacja rolnictwa ekologicznego. Przemiany w Unii Europejskiej spowodowane epidemią BSE, pryszczycy i innych chorób wiązanych z przemysłowym rolnictwem, dały impuls do państwowego wsparcia rozwoju rolnictwa ekologicznego. Obecnie w Polsce instytucje państwowe są zaangażowane we wspieranie tej formy produkcji żywności, przy Ministerstwie Rolnictwa i Rozwoju Wsi powstała wyspecjalizowana agenda Zespół ds. Rolnictwa Ekologicznego, w działania na rzecz rozwoju eko-rolnictwa włączają się coraz silniej Ośrodki Doradztwa Rolniczego i Urzędy Marszałkowskie. Choć rolnictwo 
ekologiczne pierwotnie było niszowym ruchem społecznym dziś jest całą branżą rynku, którą interesują się specjaliści od marketingu. W maju bieżącego roku w Warszawie odbywała się cała impreza branżowa Organic Marketing Forum, a targi żywności ekologicznej BIOFACH odbywają się corocznie na pięciu kontynentach goszcząc tysiące wystawców i dziesiątki tysięcy klientów.

Powstają również organizacje zakładane planowo wedle projektów ludzi ze społecznych światów nauki i polityki, mające na celu rozwój rolnictwa ekologicznego. Taką instytucją jest lubelska Dolina Ekologicznej Żywności, mająca mieć charakter tzw. klastru czyli opartej na dynamice współpracy i rywalizacji sieci organizacji, firm i instytucji zaangażowanych we wszystkie stadia produkcji i dystrybucji produktów rolnictwa ekologicznego. Jest to pewne novum, gdyż większość organizacji ekorolników miała charakter oddolny, a lubelski projekt koordynowany przez Wyższą Szkołę Przedsiębiorczości i Administracji ma charakter odgórnie planowanych działań, w oparciu o liczącą ponad 100 stron strategię napisaną przez specjalistów od marketingu. Niestety, przygotowana w ten sposób strategia nie została wdrożona. Niemniej jednak, kierunek współpracy ekorolników, naukowców oraz specjalistów od marketingu wydaje się rokować duże nadzieje, choćby tworzenie klastrów obejmujących ekoprodukcję oraz przetwórstwo.

Jeżeli chodzi o bariery rozwoju rolnictwa ekologiczne to z wywiadów wyłaniają się nieżyciowe wymagania weterynaryjno-sanitarne, nadmierne kontrole świadczące o braku zaufania do rolników. Eko-rolnicy mają żal do polskich ustawodawców, że ci chcac być bardziej papieskimi od papieża, w nadmiernie rygorystyczny sposób interpretowali unijne regulacje. Czasami rolnikom brakuje zwykłej ludzkiej życzliwości po stronie urzędników.

W kwestii rozwoju, kontrolowanie wszystkich ogniw procesu produkcyjnego w postaci przydomowego, drobnego przetwórstwa wydaje się być kluczem do niezależności ekonomicznej rolników. Ważnym procesem jest zrzeszanie się ekorolników celem tworzenia wspólnej oferty handlowej i potencjalnie wspólnych przetwórni. Ponadto, idee na rozwój obejmują eko-agroturystykę, edukację ekologiczną. Duże nadzieje polscy rolnicy wiążą z ideą eksportu zagranicznego, co jednak wymaga znalezienia odpowiedniej niszy rynkowej, jaką mógłby być np. kwas chlebowy. Niektórzy eko-rolnicy mają świadomość, że czasami barierą w rozwoju może być niewystarczająco elastyczne myślenie. 
Polskie rolnictwo ekologiczne ma zarówno swe konserwatywne, jak i nowoczesne oblicze. Najbardziej poczytny magazyn eko-rolników Eko Arka obok praktycznych informacji, przekazuje mesjanistyczną ideologią szczególnej posłanniczej roli Polski i naszego bożego rolnictwa ekologicznego, mogącego wstrzymać zagładę, do jakiej zmierza industrialny świat. Jak deklaruje Zbigniew Przybylak (2005b): rolnictwo ekologiczne, poszczególne gospodarstwa to swego rodzaju EKO ARKI niosace BOŻY POKÓJ coraz bardziej zalęknionemu światu z powodu rożnych plag typu ptasia grypa, wojen, terroryzmu, zanieczyszczenia żywności, zniszczenia przyrody, klęsk klimatycznych, zagrożeń biotechnologicznych typu GMO, klonowanie. Uważa on, iż eko-rolnicy powinni łączyć misję ekologiczną z misją chrześcijańską: tradycyjne gospodarstwa ekologiczne to również swego rodzaju znaki nadziei na przyszłość, to EKO ARKI wskazujące jak należy żyć $w$ zgodzie z Bożymi Prawami na Ziemi, jak praktycznie realizować ideę ekorozwoju, zrównoważonego rozwoju (s. 1). Co roku kilkuset rolników ekologicznych z inicjatywy Przybylaka udaje się na wspólną pielgrzymkę do Częstochowy, gdzie m.in. proszono Maryję o pomoc w walce z GMO.

Rolnicy ekologiczni oprócz stosowania preindustrialnych technik, jak ręczne pielenie czy stosowanie koni roboczych, z zainteresowaniem śledzą ekologiczne nowinki techniczne, jak panele fotowoltaiczne czy maszyny do pielenia. Kilkoro z badanych przeze mnie rolników było zafascynowanych ideą EM - efektywnych mikroorganizmu, organicznego preparatu opracowanego przez japońskich naukowców, mającego doprowadzić do zrewolucjonizowania rolnictwa ekologicznego. Warto w tym kontekście przytoczyć wypowiedź jednego z rolników ekologicznych z łódzkiego, który stwierdził, iż rolnictwo ekologiczne to jest high tech, najnowsza technologia, gdzie tam genetyczne modyfikacje - to tam jest prymityw! Tu czlowiek, który jest tego świadom to może Pana Boga za nogi złapać. Zrozumieć te wszystkie mechanizmy, które działaja w przyrodzie, poznaje się wszystkie zależności, że jedne robale nie lubia drugich, szczuje się jedne robale na drugie, i tak dalej. W tej wypowiedzi rolnik ekologiczny jawi się nie jako chłop, co to ziemie uprawia, jak pradziadowie, tylko dobrze obeznany z nowinkami nauki menedżer ekosystemów, alchemik zarządzania, inteligentny znawca wszystkich istotnych zależności w przyrodzie. U owego rolnika nie występuje postrzeganie sprzeczności pomiędzy misją a biznesem, pokorą wobec naturalnych procesów ekologicznych i ludzką zdolnością do zarządzania. 
Najważniejszy wniosek $\mathrm{z}$ niniejszej pracy to olbrzymie znaczenie misji, czynników świadomościowych w eko-rolnictwie, którego nie powinno się sprowadzać do systemu wiedzy technicznej. Jak wykazałem $\mathrm{w}$ toku mej pracy, rolnictwo ekologiczne to przebogaty świat społeczny mający swój wymiar moralny, który nie powinien zostać pominięty. Jak powiada cytowany na wstępie pracy rolnik, młodym stażem gospodarzom ekologicznym przydałyby się szkolenia z moralności rolnictwa ekologicznego. Zapewne także z jego filozofii i historii, które są niezbędne, aby rolnictwo ekologiczne funkcjonowało w swym całościowym aspekcie. 


\section{Post scriptum. Między eko-ogródkiem przy Białym Domu a groźbą likwidacji, czyli co zmieniło się w eko-rolnictwie w ciągu dwóch lat od ukończenia badań?}

Od czasu napisania pracy magisterskiej minęly dwa lata, co w kontekście 20telniej historii rozwoju polskiego eko-rolnictwa jest relatywnie długim okresem. W tym czasie na arenie światowej zaszły ważne zmiany, jak na przykład wybór nowego prezydenta USA. Michelle Obama, jego żona, postanowiła włączyć się w promowanie rolnictwa i ogrodnictwa ekologicznego, zakładając warzywny ogród ekologiczny mieszczący się w ogrodach Białego Domu. Jak donosi New York Times z 19.03.2009 roku, ekologiczny ogród, obejmujący aż 55 odmian warzyw, ma dostarczać jedzenie na oficjalne posiłki prezydenckiej rodziny. Ponadto, pani Obama chce w ten sposób zwrócić uwagę Amerykanów, a szczególnie dzieci, na znaczenie zdrowej diety opartej na jedzeniu wytwarzanym lokalnie i ekologicznie. Sama przyznała, że chce zmienić swe własne nawyki, gdyż nigdy nie uprawiała ogródka, a jako pracująca matka, karmiła dzieci pizzą i hamburgerami, co doprowadziło do ich nadwagi. Ponadto, za cel polityczny stawia zmniejszenie zależności USA od dużych przemysłowych farm, zużywających duże ilości sztucznych nawozów i ropy. Przesłanie pierwszej damy USA brzmi: Nie ma nic bardziej "cool" niż wpaść do Biatego Domu, zerwać parę warzyw, a potem ciać je i gotować $w$ kuchni wraz z Cris, Samem oraz Billem, odczuwając prawdziwa radość z owoców wlasnej pracy (NY Times 19.03.2009).

Ekologiczny ogród przy Białym Domu ma znaczenie symboliczne i jest bodajże najdonioślejszym wskaźnikiem płynącej z Zachodu mody na eko-rolnictwo i ekologię. Brytyjski książę Karol już od kilku lat propaguje eko-rolnictwo i odwiedził także polskich eko-rolników. Eko-modę widać w nowych berlińskich wieżowcach, które zbierają wodę deszczową i mają swe własne ogródki, na licznych targowiskach i sklepikach bio, organic, eko obecnych w niemal każdym mieście zachodniej Europy powyżej 50 tysięcy mieszkańców. Na Zachodzie nawet supermarkety, kontrolujące blisko $80 \%$ handlu detalicznego otworzyły przestrzenie swych półek dla towarów z certyfikatami.

Ten trend naturalnie dociera do Polski i widać go na przykładzie międzynarodowej sieci hipermarketów, która również w Polsce zaczęła kampanię 
reklamową pod hasłem "organic" i oferuje w niektórych sklepach, jak na razie skromny, ale jednak obecny, regał z produktami ekologicznymi - niestety głównie importowanymi z Zachodu. Również, znana korporacja produkująca żywność dla dzieci wprowadziła serie produktów z gwarancją ekologiczną. W tym punkcie należy postawić pytanie, czy ekologiczna moda, której symbolem jest ogródek państwa Obama oraz zainteresowanie eko-rolnictwem ze strony hipermarketów i dużych korporacji pomogą polskim eko-rolnikom? Oczywiście za wcześnie jest na definitywną ocenę ciągle rozwijającego się zjawiska, jednak już teraz widać, że wielu z eko-rolników ciągle ma problemy $\mathrm{z}$ dotarciem ze swymi produktami do zainteresowanych odbiorców, a część sprzedaje swoje wytwory w cenie produktów konwencjonalnych. Jednocześnie brak jest silnych grup producenckich, które mogłyby stanowić poważnych kontrahentów dla supermarketów, a twórca sieci wegetariańskich restauracji twierdzi, że nie korzysta z produktów rolnictwa ekologicznego ponieważ ciągle jest zbyt mała podaż, jak na potrzeby dużej sieci.

Ważnym rysem polskiego społecznego świata rolnictwa ekologicznego oprócz wspomnianego niskiego stopnia integracji rolników i braku rozwiniętego rynku zbytu, są silne obawy rolników i sympatyków - konsumentów, przez negatywnymi interwencjami płynącymi z Brukseli lub Waszyngtonu. Niedawno miesięcznik Nieznany Świat a wraz z nim wiele innych portali poświęconych eko-rolnictwu, ziołom, zdrowemu życiu opublikowało list protestacyjny przeciwko próbom zakazania przez Unię Europejską rolnictwa ekologicznego i wszelkiego rodzaju terapii naturalnych (zielarstwo, ajurweda, homeopatia). Podejrzenia związane z podjęciem takich działań spadły na lobby alchemiczne, zwłaszcza korporacje produkujące genetycznie modyfikowaną żywność, które wykorzystując argument o podniesieniu standardów sterylności i higieny występują przeciw eko-rolnictwu. Powstała specjalna strona www.stopcodex.pl mająca na celu sprzeciw wobec wprowadzenia przez Światową Organizację Zdrowia WHO i Światową Organizację Żywnościową FAO kodeksu żywnościowego, który czyniłby rolnictwo ekologiczne nielegalnym. Przeciwnicy Codexu grożą, iż:

- „cała żywność może być napromieniowana bez powiadomienia konsumenta (zob. zezwolenie FDA w USA na napromieniowanie) i może zawierać dodatki chemiczne oraz pestycydy, będąc nadal nazywana „żywnością ekologiczną”(zob. Zielona Księga UE) 
- wszystkie zwierzęta przeznaczone na mięso możliwe, że będą musiały zażywać antybiotyki i hormony wzrostu, lącznie $\mathrm{z}$ hodowanymi ekologicznie

- możliwe z czasem przydomowa uprawa własnych owoców i warzyw nie będzie możliwa bez zezwolenia

- sprzedaż naturalnych witamin, suplementów mineralnych i ziół może być nielegalna, podobnie jak terapie naturalne stosujące te składniki” (www.stopcodex.pl).

Z kolei we wrześniu 2009 roku na portalu społecznościowym facebook i na wielu stronach internetowych pojawił się list autorstwa amerykańskich zwolenników eko-rolnictwa, wedle którego, Izba Reprezentantów i Senat wkrótce (w przeciagu póltora tygodnia) poddadza głosowaniu ustawę, która zabroni rolnictwa ekologicznego (bill HR 875). Jej autorzy strasznie się spieszq by przeglosować ustawe $w$ ciagu dwu tygodni, zanim ludzie zdadza sobie sprawę o co chodzi. Gtównym sprawca i lobbista jest Monsanto - gigant zajmujący się inżynieria chemiczna i genetycznq (a także Cargill, ADM oraz 35 innych agro-gigantów). Ta ustawa zmusi gospodarstwa ekologiczne do używania specjalnych nawozów oraz trujących sprayów przeciw owadom, wskazanych przez nowo utworzonq agencje w celu "zapewnienia, iż nie będa istnieć niebezpieczeństwa dla publicznego zaopatrzenia żywnościowego". Nakaz obejmie ogródki przydomowe, produkujące jedynie dla potrzeb rodziny.

Pod apelem podpisują się dziesiątki tysięcy zwolenników eko-rolnictwa z całego świata. Trudno mi ocenić obiektywnq realność zagrożeń, jakkolwiek trudno sobie wyobrazić by tak rozwinięte i dające miliony miejsc pracy w skali Europy branże jak rolnictwo ekologiczne i terapie naturalne miały przestać istnieć, skupię się więc na tym, jakie tego rodzaju apele mają wpływ na samookreślenie zwolenników ekorolnictwa. Spór między rolnictwem ekologicznym a modyfikowanym genetycznie prowadzi bowiem do ostrej polaryzacji, gdyż obie strony zdają sobie sprawę, że pokojowa koegzystencja obydwu, skrajnie odmiennych rodzajów rolnictwa jest niemal niemożliwa. Używane przez zwolenników GMO środki ochrony roślin i ich bardzo odpornych odmian, mają wpływ na lokalne eko-systemy (wody, zwierzęta) i zasięg oddziaływania na wiele kilometrów wokół pola, mogą także prowadzić do zanieczyszczenia upraw ekologicznych. Zwolennicy eko-rolnictwa zazwyczaj żądają całkowitego zakazu upraw modyfikowanych genetycznie i podział ten wydaje się być najważniejsza areną sporu w społecznym świecie eko-rolnictwa. Ponadto kwestią 
sporną pozostają nasiona: korporacje agrochemiczne dążą do monopolizacji wytwarzania nasion, chcą by rolnicy byli zmuszeni do zakupu nasion terminalnych niezdolnych do rozmnażania się, oraz odmawiają im prawa do zachowywania i sprzedawania nasion. Eko-rolnicy i sympatycy ekologii zdają sobie sprawę, z siły przeciwnika, obejmuje on największe na świecie korporacje agrochemiczne, instytuty naukowe, partie polityczne i są przygotowani na ciągłe nowe ataki legislacyjne. Atmosfera wojny może prowadzić do syndromu oblężonej twierdzy i potęguje odczucia niepewności i tymczasowości życia w społeczeństwie ryzyka (Beck 2002). Jak można bowiem spokojnie i z ufnością wykonywać swoje podstawowe działanie, jakim jest produkcja żywności ekologicznej, gdy w każdej chwili jednym podpisem urzędnika to, podstawowe działanie stanie się nielegalne?

Postanowiłem sprawdzić też, jakie zmiany zaszły wśród respondentów z którymi rozmawiałem dwa lata temu. Udało mi się odwiedzić w gospodarstwie Zbigniewa Bednarka, prezesa opisanego w mej pracy przypadku inicjatywy integracji ekorolników - Eko Centrum Zelów. Okazało się, że zastałem go w momencie zawieszania działalności Stowarzyszenia. Jak zauważył, jako rolnik pracuje dwadzieścia cztery godziny na dobę, bo choćby krowa może się cielić $w$ nocy i w związku z tym nie miał czasu na znaczną ilość pracy administracyjnej i związanej z pozyskiwaniem funduszy. Ekorolnicy bardzo potrzebują wsparcia ze strony fachowców - koordynatorów projektów czy pracowników biurowych. W innych gminach pomocą służą niekiedy urzędnicy ODRów czy Urzędu Gminy, jednak w tym wypadku zainteresowanie $\mathrm{z}$ ich strony było niewielkie. Wskazywał również, że kolejność podjętych działań przez Eko Centrum mogła być niewłaściwa, stowarzyszenie zostało bowiem założone, gdy członkowie - rolnicy byli w trakcie przestawiania się na metody ekologiczne. Z perspektywy doświadczeń, lepszym sposobem mogło być pozwolenie aby najpierw poszczególni rolnicy zmierzyli się najpierw z trudami samodzielnego konkurowania, aby dojrzeć do przekonania, że w grupie jest łatwiej współzawodniczyć, łatwiej sprzedawać, promować czy zdobywać informacje. Ponadto doświadczenia mojego rozmówcy pokazały większą sensowność tworzenia. grupy producenckiej wąsko ukierunkowanej na specjalizację produkcyjną i marketing niż stowarzyszenia, które miało wiele innych celów społecznych oraz edukacyjnych. Podjęcie współpracy z innymi rolnikami jest jednak niezwykle istotne, choćby ze względu na trudności związane ze sprzedażą towarów: tylko 1/3 mleka, 
które wytwarza pan Zbigniew, sprzedaje jako ekologiczne, resztę natomiast oddaje do mleczarni po niskiej stawce $50 \mathrm{gr}$ za litr, gdzie jest mieszane $\mathrm{z}$ mlekiem konwencjonalnym. Jako pozytywny przykład podaje ekorolników ze świętokrzyskiej Eko Nidy, którym po prostu z prawdziwej biedy bardzo się chciało działać razem. Jako czynnik hamujący rozwój eko-rolnictwa wskazal, alternatywne formy zatrudnienia, takie jak: cegielnia, praca w pobliskiej elektrowni czy kopalni.

Niemniej, Bednarek pozostaje optymistą, gdyż wierzy, że ekorolnictwo to przyszłość: wystarczy spojrzeć, jak pięknie się rozwija w zachodniej Europie. Ma również nadzieję, że w przyszłości jemu i innym uda się zrealizować pomysły na zrównoważony rozwój wsi, jakie wypracowali w Eko Centrum, na przykład stworzenie matecznika ze starymi szczepami drzew, z którego można by potem rozmnażać drzewa i stwarzać unikalne produkty regionalne. W tym celu sześciu rolników wystąpiło do fundacji zajmującej się rozwojem wsi o 10 tysięcy złotych na zakup 600 drzewek. Spotkali się z brakiem zrozumienia ze strony miejskich urzędników, którzy odrzucili projekt, uznając, iż projekt powinien być bardziej demokratyczny i zakładać rozdanie po 1 drzewku każdemu z 600 beneficjentów. Ale wtedy -pyta - kto by dbat o te drzewka, kontrolowat to, pracowal nad tym? Jest to bardzo dobry przykład na to jak pomysły mogą nie zostać sfinalizowane ze względu na wytyczne, którymi kierują się urzędnicy zwracający większą uwagę na realizację abstrakcyjnych wartości, w oderwaniu od realiów wsi.

Inna inicjatywa związana była $\mathrm{z}$ gruntownym remontem starego wiatraka, który mógłby stać lokalną atrakcją turystyczną. Projekt nie został jednak zrealizowany, gdyż wiatrak znajduje się na terenie prywatnym, zatem gmina nie wyraziła zgody na jego sfinansowanie. Jednakże w szerszej perspektywie, którą reprezentuje pan Bednarek, umożliwienie prywatnemu właścicielowi stworzenia atrakcji turystycznej, może stać się kołem zamachowym rozwoju wsi, a nawet gminy: gdyby prywaciarz zrobit porzadna agroturystyke, to by $i$ od niego turyści przychodzili do mnie po mleko, a do kolegów po ser czy chleb, wielu sqsiadom daliby zarobić. Niezależnie od szans na powodzenie tego konkretnego projektu, umiejętność takiego szerszego spojrzenia na własną korzyść uważam za kluczowy element w rozwoju rolnictwa ekologicznego.

Konkludując, trudno w rolnictwie ekologicznym o uzyskanie jednolitego obrazu zmian. $\mathrm{Z}$ jednej strony istnieją powody do optymizmu: rosną wskaźniki popularności eko-rolnictwa (wzrost liczby eko-gospodarstw w Polsce do około 12 
tysięcy, dwukrotny wzrost liczby przetwórni w latach 2005-2007 do liczby 207, powstawanie nowych eko-sklepów, większa obecność produktów ekologicznych w hipermarketach), a na świecie popularność organic farming zatacza szersze kręgi obejmując nawet Biały Dom. Z drugiej strony, rolnicy działają w strachu przed całkowitym zakazem ich działalności przez odległe, anonimowe instytucje. Ponadto lokalne inicjatywy integrujące upadają, strategie rozwoju klastrów pozostają na papierze, a większość znanych mi eko-rolników żyje ubogo, nie znajdując pełnego zbytu dla swej produkcji. Wyłania się więc obraz niejednoznaczny, więcej pytań o przyszłość niż odpowiedzi. 


\section{Aneks}

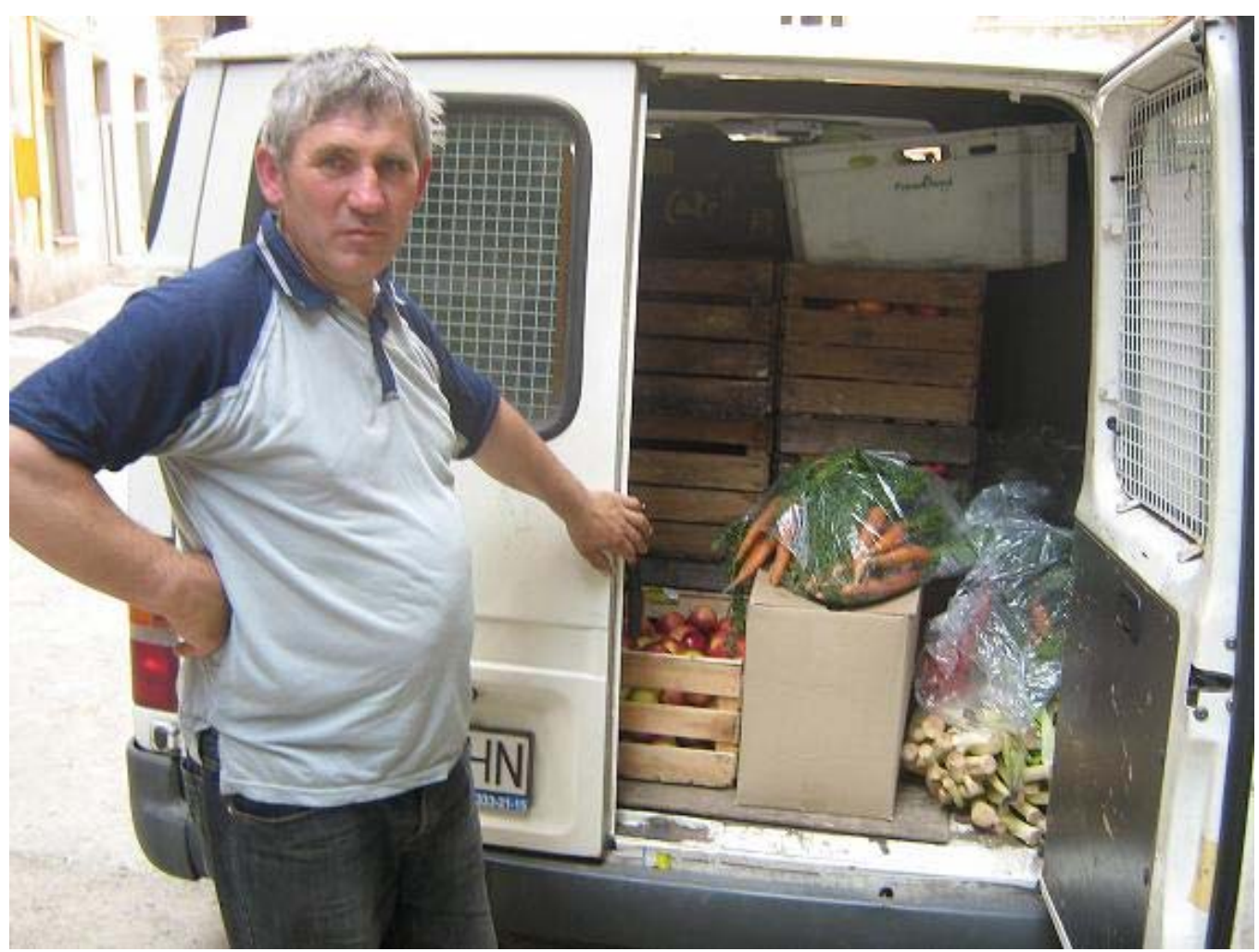

Zdjęcie nr 1: Eko-rolnik (autor: Piotr Bielski)

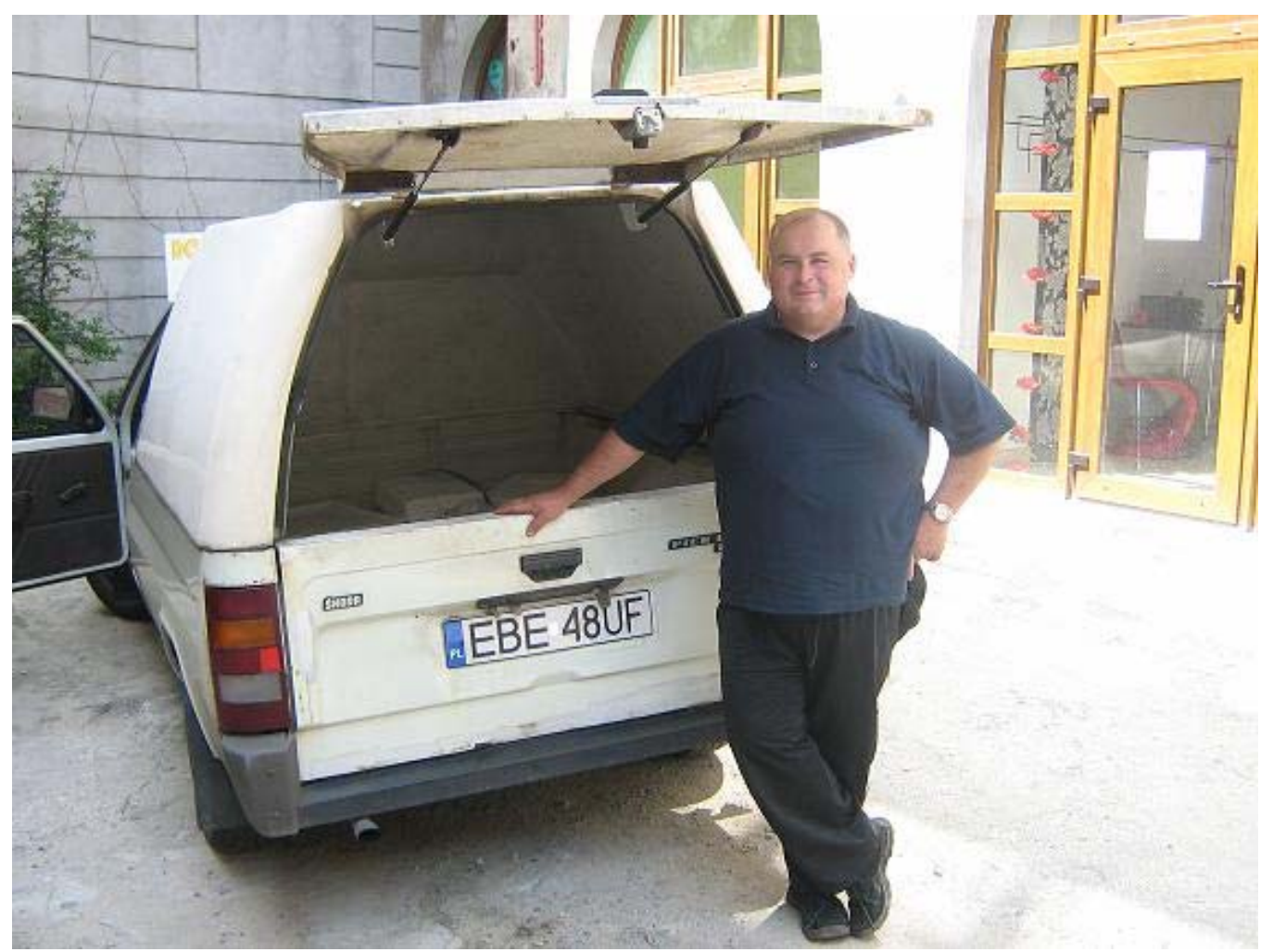

Zdjęcie nr 2: Eko-rolnik (autor: Piotr Bielski) 


\section{Bibliografia}

Babbie, Earl (2004) Badania społeczne w praktyce. Warszawa: Wydawnictwo Naukowe PWN.

Becker, Howard (1977) Sociological Work. Method and Substancje. New Jersey: Transaction Books.

Berger, Peter L. i Thomas Luckmann (1983) Spoteczne tworzenie rzeczywistości. Warszawa: Państwowy Instytut Wydawniczy.

Blumer, Herbert (1969) Symbolic Interactionism. Perspective and Method. New Jersey: Prentice-Hall.

------, (1984) "Społeczeństwo jako symboliczna interakcja" w Kryzys i Schizma, Antyscjentystyczne tendencje w socjologii wspótczesnej (Red) E. Mokrzycki. Warszawa: Państwowy Instytut Wydawniczy.

Bokszański, Zbigniew (2005) Tożsamości zbiorowe. Warszawa: PWN.

Bołtromiuk, Artur (2005) Rola Wsparcia Publicznego w Rozwoju Rolnictwa Ekologicznego w Polsce. Maszynopis otrzymany od autora.

Burros, Marian (2009) "Obamas to Plant Vegetable Garden at White House." New York Times 19.03.2009 (http://www.nytimes.com/2009/03/20/dining/20garden.html)

Biuletyn Demeter nr.5/2006.

Bubula, Barbara (2004) „Orkisz, płaskurka i piękna z Boskoop.” Obywatel 2 (16).

Geertz, Clifford (2005) Interpretacja kultur. Wybrane eseje. Kraków: Wydawnictwo Uniwersytetu Jagiellońskiego.

Goffman, Erving (1981) Człowiek $w$ teatrze życia codziennego. Warszawa: Państwowy Instytut Wydawniczy.

Gross, Matthias (2001) „Unexpected Interactions. Georg Simmel and the Observation of Nature.” Journal of Classical Sociology 1.

Glaser, Barney i Anselm Strauss (1967) The Discovery of Grounded thoery. Strategies for Qualitative Research. New York: Aldine Publiching Co. 
Górny, Mieczysław (1992) Ekofilozofia rolnictwa. Krosno: Centrum Edukacji Ekologicznej Wsi.

------, (1997) Dlaczego rolnictwo ekologiczne jest ważne dla Polski?. Maszynopis.

------, (2002) Ekorozwój wsi i rolnictwa. Włocławek: Wydawnictwo Duszpasterstwa Rolników.

------, (2005a) Historia rolnictwa ekologicznego. Przysiek: Wydawnictwo KujawskoPomorskiego Ośrodka Doradztwa Rolniczego w Minikowie.

------, (2005b) "Uratować tyle życia ile można." Eko Arka 3: 32-33.

------, (2005c) "Wiek rolniczych kłamstw." Eko Arka 4: 32-33.

Hałas, Elżbieta, redaktor i Krzysztof Konecki, redaktor (2005) Konstruowanie jaźni ispołeczeństwa. Europejskie warianty interakcjonizm symbolicznego. Warszawa: Wydawnictwo Naukowe "Scholar".

Hammerslay, Martyn i Paul Atkinson (2000) Metody badań terenowych. Poznań: Wydawnictwo Zysk i S-ka.

IFOAM Annual Report 2008, stan na 30.9.2009 (www.ifoam.org).

IJHAR-S (2008) Liczba gospodarstw z certyfikatem $i w$ okresie przestawiania $w$ poszczególnych województwach w 2007 roku, (www.ijhars.gov.pl).

IJHAR-S (2009) Producenci ekologiczni w 2008 roku, (www.ijhars.gov.pl) Jawłowska, Aldona (2001) Wokót problemów tożsamości. Warszawa: ISNS UW .

Kacperczyk, Anna (2005) "Zastosowanie koncepcji społecznych światów w badaniach empirycznych." w Hałas, Elżbieta, redaktor i Krzysztof Konecki, redaktor (2005) Konstruowanie jaźni ispołeczeństwa. Europejskie warianty interakcjonizm symbolicznego. Warszawa: Wydawnictwo Naukowe "Scholar".

Kocik, Lucjan (2000) Między przyroda, zagroda i społeczeństwem. Kraków: Wydawnictwo Uniwersytetu Jagielońskiego.

Konecki, Krzysztof (1992) Nowi pracownicy a kultura organizacyjna. Studium folkloru fabrycznego. Łódź: Wydawnictwo Uniwersytetu Łódzkiego, Folia Sociologica 24.

------, (1994) Kultura organizacyjna japońskich przedsiębiorstw przemystowych. Studium Socjologiczne. Łódź: Wydawnictwo Uniwersytetu Łódzkiego. 
------, (1998) Łowcy Glów. Headhunting. Analiza pracy rekrutacji w agencjach doradztwa personalnego. Warszawa: Wydawnictwo Normalizacyjne Alfa Wero.

------, (2000) Studia z metodologii badań jakościowych. Teoria ugruntowana. Warszawa: PWN.

------, (2005) Ludzie i ich zwierzęta. Interakcjonistyczno-symboliczna analiza spolecznego świata wlaścicieli zwierząt domowych. Warszawa: Scholar.

Lulewicz, Małgorzata (2006) „Czynniki kształtujące motywacje rolników do przestawiania gospodarstw na ekologiczne metody produkcji na przykładzie powiatu Maków Mazowiecki w województwie mazowieckim”. Niepublikowana praca licencjacka, Wydział Ekonomiczno-Rolniczy, Szkoła Główna Gospodarstwa Wiejskiego, Warszawa.

Lutyński, Jan (2000) Metody badań spolecznych. Łódź: Łódzkie Towarzystwo Naukowe.

Łopata, Jadwiga (2002) „Zróbcie wszystko, żeby to ocalić. Z Jadwigą Łopatą rozmawia Barbara Bubula”. Obywatel 4 (8): 6-10.

Merton, Robert (2002) Teoria socjologiczna i struktura spoleczna. Warszawa: PWN.

Metera, Dorota i Tomasz Sakowski (2008) Podręcznik rolnictwa ekologicznego, Radom: Centrum Doradztwa Rolniczego w Brwinowie.

Miles, Matthew i Micheal Huberman (2000) Analiza danych jakościowych. Białystok: Wydawnictwo Trans Humana.

NIK (2006), Informacja o wynikach kontroli funkcjonowania rolnictwa ekologicznego $w \quad$ Polsce, $\quad$ Warszawa http://bip.nik.gov.pl/pl/bip/wyniki_kontroli_wstep/inform2006/2005182

Norberg-Hodge, Helena, Peter Goering i John Page (2001) From the Ground Up. Rethinking Industrial Agiculture. London - New York: Zed Books.

Okraska, Remigiusz (2002) „Wieś na rozdrożu”, Obywatel 4 (8): 13-24.

Olechnicki, Krzysztof (1998) New Age. Kościót wobec wyzwania Wodnika. Warszawa: Oficyna Naukowa. 
Osetek, Julian i Jerzy Osetek (1989) Rolnictwo i Ogrodnictwo Biodynamiczne. Bydgoszcz: Przedsiębiostwo Innowacyjne "Otylia"

Przybylak, Zbigniew (2003) Stawne proroctwa, objawienia, przepowiednie dla Polski i świata na XXI wiek. Bydgoszcz: Wydawnictwo Gaj.

------, (2005a) "Żal w Eko Arce", Eko Arka nr 3, s. 1.

------, (2005b) "Pokój z EKO ARKI", Eko Arka nr 4, s. 1.

------, (2006a) "Największa Moc", Eko Arka nr 2, s.1

------, (2006b) "Znak Prawdy z Eko Arki", Eko Arka nr 3, s.1

------, (2006c) "Od seradeli do chleba i rogalików", Eko Arka nr 3, s. 2-5

------, (2007a) "Ekologia pokoju z Eko Arki", Eko Arka nr 1, s. 1

------, (2007b) "Boża ekonomia z Eko Arki", Eko Arka nr 2, s. 1

------, (2007c) "Opiekunka Eko Arki", Eko Arka nr 3, s. 1

------, (2007d)"Dobrostan Eko Arki." Eko Arka nr 4, s. 1

------, (2009a) "Ratunkowe szalupy Eko Arki." Eko Arka nr 2, s. 1

------, (2009b) "Nowe życie gospodarcze z Eko Arki." Eko Arka nr 3, s. 1

Przybylak-Zdanowicz Magdalena (2007) „III Pielgrzymka Rolników Ekologicznych na Jasną Górę.” Eko Arka nr 1, s. 31-32

Przybyłowska, Ilona (1978) „Wywiad swobodny ze standaryzowaną listą poszukiwanych informacji i możliwości jego zastosowania w badaniach socjologicznych.” Przegląd Socjologiczny XXX.

Rokicka, Ewa i Paweł Starosta (2003) Postawy mieszkańców gmin polskich wobec środowiska naturalnego. Łódź: Wydawnictwo Absolwent.

Runowski, Henryk (1996) Ograniczenia i szanse rolnictwa ekologicznego. Warszawa: Wydawnictwo SGGW.

Siebeneicher, George (1997) Podręcznik rolnictwa ekologicznego. Warszawa: Wydawnictwo Naukowe PWN.

Simmel, Georg (1975) Socjologia. Warszawa: PWN. 
Skolimowski, Henryk (2007) Geniusz Światta a Świętość Życia. Warszawa: Oficyna Wydawnicza VEGA.

Sołtysiak, Urszula (1993) Rolnictwo ekologiczne od teorii do praktyki. Warszawa: Wydawnictwo Stowarzyszenia Ekoland.

------, (1994) Rolnictwo ekologiczne $w$ praktyce. Warszawa: Wydawnictwo Stowarzyszenia Ekoland.

------, redaktor (1995) Rolnictwo ekologiczne. Od producenta do konsumenta. Warszawa: Wydawnictwo Stowarzyszenia EKOLAND.

------, redaktor (1998) Ekologiczna produkcja żywności w świetle wymogów Unii Europejskiej. Poznań: Wydawnictwo Centrum Doradztwa i Edukacji w Rolnictwie w Poznaniu.

Starosta, Pawel, Imre Kovach, Krzysztof Gorlach (1999) Rural Societies under communism and beyond. Łódź: Wydawnictwo Uniwersytetu Łódzkiego.

Steiner, Rudolf (1999) Stosunek świata gwiazd do człowieka. Gdynia: Wydawnictwo Genesis.

------, (2003) Od fizyczności czlowieka do duchowości świata. Gdynia: Wydawnictwo Genesis.

Stopa, Magdalena (2009) "Rzut Beretem", National Geographic Polska 4/2009 (http://www.national-geographic.pl/artykuly/pokaz/rzut-beretem/)

Sułek, Antoni, Nowak K i Wyka, Anna (1989) Poza granicami socjologii ankietowej. Warszawa: UW i PTS.

Sztumski, Janusz (1995) Wstęp do metod i technik badań spotecznych. Katowice: Wydawnictwo "Śląsk".

Ślęzak, Izabela (2009) „Stawanie się poetą. Analiza interakcjonistyczno symboliczna”. Przegląd Socjologii Jakościowej V

Stratenwerth, Peter (2006) Wsi spokojna, wsi wesoła. Stow. Ziarno: Grzybów.

Thun, Maria (1998) Pielegnacja ogrodu. Dni Siewu. Czas sadzenia. Dni zbioru. Nakło nad Notecią: Wydawnictwo Otylia.

Ustawa z dnia 20.04.2004 r. o rolnictwie ekologicznym, Dz.U. Nr. 93, poz. 898 (www.lex.pl) 
Weber, Max (1998) Polityka jako zawód i powolanie. Kraków: ZNAK.

Wilson, Thomas P. (1973) "Normative and Interpretative Paradigms in Sociology" w Understanding Everyday Life. Toward the reconstruction of sociological knowledge. (Red) Jack Douglas. London: Routledge and Kegan Paul.

Woś, Augustyn i Zegar, Józef (2002) Rolnictwo Spolecznie Zrównoważone. Warszawa: IERiGŻ.

www.anandamarga.pl

www.boell.pl

www.ekocentrum.org.pl (stan na 15.05.2007, strona już nie istnieje)

www.ekoland.org.pl

www.dolinaeko.wspa.lublin.pl

www.klastry.pl

www.minrol.gov.pl

www.wikipedia.pl

Zirakzadeh, Cyrus Ernesto (1997) Social Movements in Politics: A Comparative Study. Londyn - Nowy Jork: Longman.

Żakowska-Biemans, Sylwia, i Krystyna Gutkowska (2003) Rynek żywności ekologicznej w Polsce i w krajach Unii Europejskiej. Warszawa: Wydawnictwo SGGW.

\section{Cytowanie}

Bielski, Piotr (2009) "Rolnictwo ekologiczne jako zawód i powołanie. Studium tożsamości, organizacji i potencjału rozwojowego polskich rolników ekologicznych”. Przegląd Socjologii Jakościowej, Tom V Numer 3. Pobrany Miesiąc, Rok (http://www.qualitativesociologyreview.org/PL/archive_pl.php). 